Educación multidisciplinar para la igualdad de género; no3 edición científica

Julia Haba Osca, Nuria Sánchez León y Ana Sevilla Pavón

\title{
Perspectivas lingüísticas, literarias y científico-tecnológicas
}

coordinación Julia Haba Osca

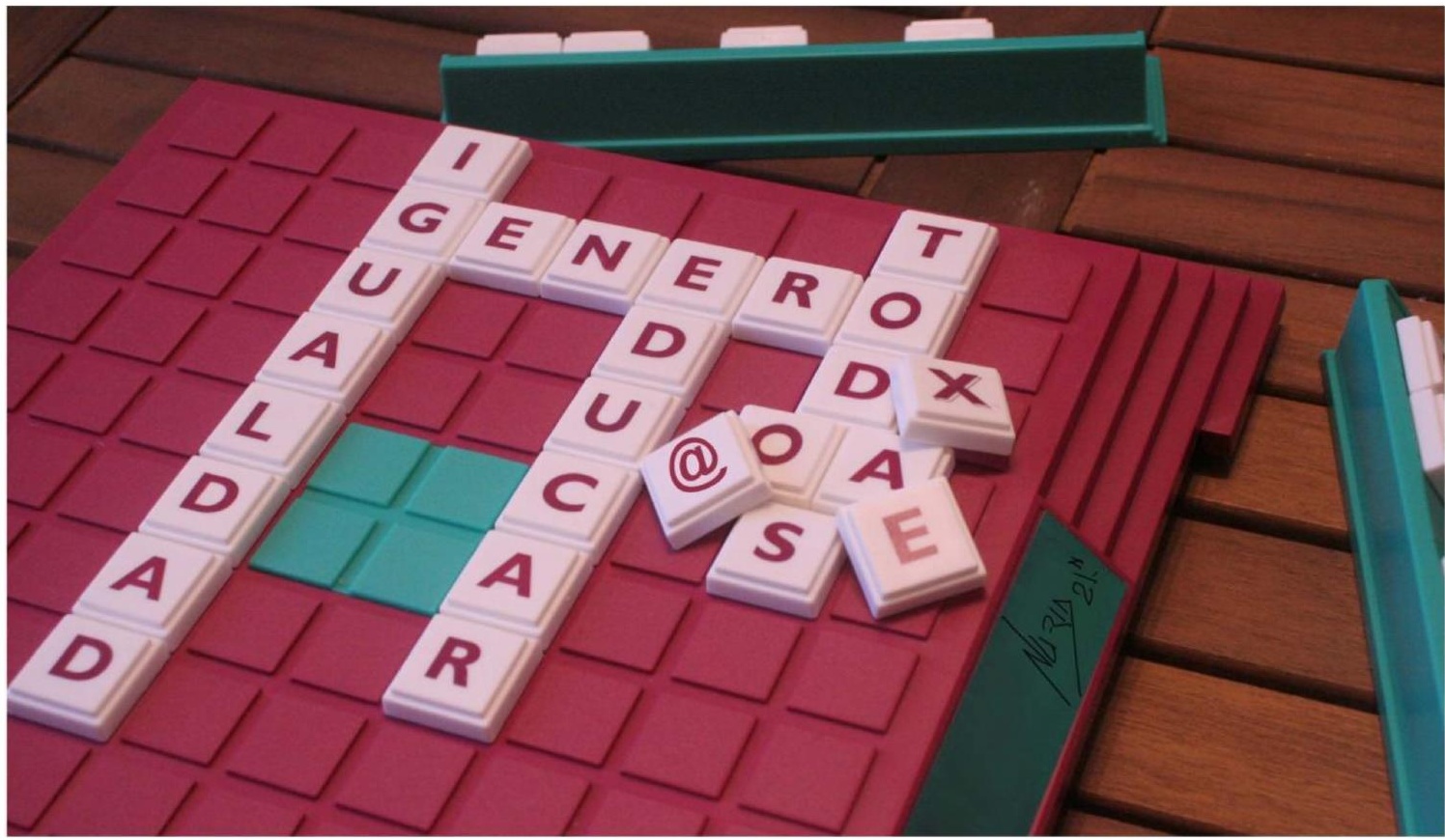


Educación multidisciplinar para la igualdad de género;n 3

edición científica

Julia Haba-Osca

Nuria Sánchez-León

Ana Sevilla-Pavón

\title{
Perspectivas lingüísticas, literarias y científico-tecnológicas
}

\author{
coordinación \\ Julia Haba-Osca
}

2021

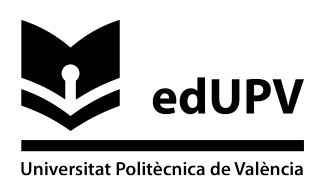




\section{Colección}

Educación multidisciplinar para la igualdad de género; $n^{\circ} 3$

ISSN 2792-7547

Los contenidos de esta publicación han sido evaluados mediante el sistema doble ciego, por el comité editorial que en ella se recoge.

Edición científica

Julia Haba Osca (Universitat de València)

Nuria Sánchez León (Universitat Politècnica de València)

Ana Sevilla Pavón (Universitat Politècnica de València)

Comité editorial

Almir de Souza Pacheco (Universidade Federal do Amazonas - Manaus, Brasil)

Marta Giralt (University of Limerick, Irlanda)

Kyria Rebeca Finardi (Universidade Federal do Espirito Santo, Brasil)

Francisco González Sala (Universitat de València, España)

José Germán Toloza Hernández (Universidad Industrial de Santander (Colombia)

Edición técnica

edUPV

Título Perspectivas lingüisticas, literarias y científico-técnológicas

Coordinación Julia Haba Osca

(C) Imagen de portada: Nuria Sánchez León

Editado por edUPV

www.lalibreria.upv.es / Ref.: 6700_01_01_01

doi.org/10.4995/EMIG.2021.670001

ISBN: 978-84-9048-836-2

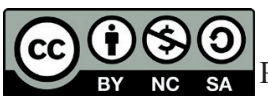

Se permite la reutilización y redistribución de los contenidos siempre que se reconozca la autoría y se cite con la información bibliográfica completa. No se permite el uso comercial ni la generación de obras derivadas. 


\section{Prólogo}

La educación para la igualdad de género es, sigue siendo, una asignatura pendiente que precisa de nuestros esfuerzos y compromiso por visibilizar y reivindicar la necesidad de introducirla como eje transversal en todas las disciplinas. Por ello, la iniciativa que desde hace seis años organizan Julia Haba Osca, Ana Sevilla Pavón y Núria Sánchez León al desarrollar la jornada Educación Multidisciplinar para la Igualdad de Género, abordando la perspectiva de género en diversos ámbitos de estudio, es especialmente importante. Como lo es el hecho de que hagan un acopio de las contribuciones a las jornadas y publiquen volúmenes como este, de acceso abierto, para impulsar su difusión libre y extensiva.

Vivimos en una época de sensibilización con las cuestiones de género, pero también de enormes resistencias y discursos de odio. Actualmente, el feminismo de la cuarta ola (sin olvidar que cada ola ha recogido los frutos de la anterior y sus debates) aglutina todos los feminismos actuales y se interesa por nuevas cuestiones en torno a la identidad de género y la diversidad. Se trata de un feminismo plural que no puede desligarse de los aspectos culturales e identitarios en su voluntad por atender las demandas de las mujeres y de otros colectivos sociales también en pugna con el patriarcado, la cultura machista y desigual que nos rodea y la violencia simbólica que imprime en la sociedad. Un feminismo que es interseccional, transnacional, intergeneracional e indisociable de las reivindicaciones identitarias, como las de las personas racializadas y queer. Un feminismo en el que, más que nunca, se está debatiendo sobre cómo promover un uso inclusivo del lenguaje, y en el que destacan el empleo de las redes sociales y las movilizaciones en la calle.

Pues el feminismo no es solo la lucha por la igualdad, sino también una lucha contra la opresión. Se trata de terminar con el patriarcado que nos asfixia, y con todas sus violencias. La desigualdad no solo se enmarca en el sexismo, sino también en el clasismo, el heterosexismo, el racismo... pues la opresión patriarcal tiene varios ejes y por eso es esencial la perspectiva interseccional en la que estamos incidiendo en esta ola feminista. 
El feminismo es, en suma, un movimiento de justicia social en el que la educación en valores de igualdad de género es clave y es un reto pendiente en todas las etapas educativas, también en la educación superior. Así, en 2019, desde EUFEM (Plataforma Universitaria de Estudios Feministas y de Género) elaboramos unas «Reivindicaciones para el avance de los estudios feministas y de género en la universidad $\aleph^{[1]}$ de las que en este prólogo quisiera destacar la siguiente:

Reivindicamos que se incluya docencia para integrar la perspectiva de género en grados y postgrados, en todos los ámbitos, para que se difunda y profundice el conocimiento transversal de las cuestiones de género, las cuáles afectan y competen a cualquier área de conocimiento. Esta inclusión ha de hacerse de forma muy transversal, evitando la creación de asignaturas gueto, por lo que cabe apostar por asegurar que la perspectiva de género se incluya en materias troncales, además de en materias optativas, y que sea un elemento evaluable en los procesos de acreditación de calidad de la enseñanza. Todas las guías docentes deberían incluir alguna competencia relacionada con la igualdad y hacer uso de lenguaje inclusivo.

Por todo ello, son esenciales iniciativas transversales como esta sobre educación multidisciplinar para la igualdad de género. Proseguir con ellas es clave para el bien común. La educación es el camino para tratar de construir, entre todas, todos y todes, un mundo más justo. Un mundo donde no sea posible que la violencia machista esté instalada de manera estructural en las sociedades; donde las cifras de víctimas, tanto las que lamentablemente han perdido la vida como las que sufren violencias como maltrato físico o psicológico, agresiones sexuales, acoso o trata con fines de explotación sexual, entre otras, no aumenten cada día. Las resistencias que nos encontramos en este empeño son enormes, pero la energía que nos impulsa en la lucha por una sociedad igualitaria y digna es mayor.

Dora Sales

Instituto Universitario de Estudios Feministas y de Género Purificación Escribano

Universitat Jaume I

[1] EUFEM (2019) Reivindicaciones para el avance de los estudios feministas y de género en la universidad. https://plataformauniversitariafemgen.wordpress.com/2019/11/24/reivindicaciones-para-elavance-estudios-feministas/ 


\section{Índice}

\section{Parte I: Perspectivas lingüísticas, literarias y traductológicas}

Capítulo 1. Aportaciones recientes a la igualdad de género en la educación multidisciplinar: lingüística y literatura, emprendimiento, ciencias experimentales, psicología y expresión artística 3 Ana Sevilla-Pavón, Universitat de València Nuria Sánchez León, Universidad de Zaragoza

Capítulo 2. Sexismo lingüístico, el variacionismo para fomentar la igualdad de género

Manuel Rodríguez Peñarroja, Universitat Jaume I

Capítulo 3. La voz de la Sirena de Carme Riera. Una lectura hipertextual 33 Elisabet Contreras Barceló, Universitat de Barcelona

Capítulo 4. Cabrera Infante en boca de Suzanne Jill Levine: Tres Tristes Tigres en clave feminista

Robert Martínez-Carrasco, Eva Peñarrocha, Universitat Jaume I

\section{Parte II: Perspectivas didácticas, sanitarias y científico-tecnológicas}

Capítulo 5. El cómic y el álbum ilustrado como recurso para la educación en la diversidad de género y afectivo-sexual Andrés Giner Latorre, IES Font de Sant Lluís (Valencia)

Capítulo 6. La llegada a la otra cara de la Luna: eclipsadas por los hombres 83 Rocío Domene-Benito, Universidad de Valladolid 
Capítulo 7. Proyecto Girls4STEM: fomento de vocaciones científico-tecnológicas desde la igualdad y la diversidad 101

Silvia Rueda, Dra. Emilia López-Iñesta, Carmen Botella-Mascarell, Joaquín Pérez, Esther de Ves, Xaro Benavent, Anabel Forte, Esther Dura, Sandra Roger, Cristina Portalés, Daniel García-Costa y Paula Marzal, Universitat de València

Capítulo 8. Enfermería y Género 121

Francisca Esteve Claramunt, Concepción Martínez Martínez, Universidad Europea de Valencia

\section{Parte III: Perspectivas sociales, psicológicas y artístico-teatrales}

Capítulo 9. Las sinergias para la inclusión de la perspectiva de género universitario

Genoveva Ramos Santana, Amparo Pérez Carbonell, Universitat de València

Capítulo 10. Fomentando la participación de personas mayores en Perspectiva de Género: una experiencia con agentes activos de cambio social 153

Julia Haba Osca, Sandra Simó Teufel, Universitat de València

Capítulo 11. Moby Dick o el mal amor: violencia de género y obsesión desde el clásico de Melville

Daniel M. Ambrona Carrasco, Colegio La Baronía San Antonio Abad de Gilet (Valencia)

Capítulo 12. La SubTerránea: teatro poético hecho por mujeres 193 Robert March i Tortajada, Universitat de València 


\section{Parte I}

\section{Perspectivas lingüísticas, literarias y traductológicas}





\title{
Capítulo 1 \\ Aportaciones recientes a la igualdad de género en la educación multidisciplinar
}

\author{
Ana Sevilla-Pavón \\ IULMA/Dept. Filologia Anglesa i Alemanya \\ Universitat de València
}

Nuria Sánchez León Dpto. de

Didácticas Especificas

Universidad de Zaragoza

\begin{abstract}
“'El patriarcado es un juez que nos juzga por nacer y nuestro castigo es la violencia que no ves. El patriarcado es un juez que nos juzga por nacer y nuestro castigo es la violencia que ya ves. Es feminicidio, impunidad para el asesino, es la desaparición, es la violación. Y la culpa no era mía, ni dónde estaba, ni cómo vestía. Y la culpa no era mía, ni dónde estaba, ni cómo vestía. Y la culpa no era mía, ni dónde estaba, ni cómo vestía. Y la culpa no era mía, ni dónde estaba, ni cómo vestía. El violador eras tú. El violador eres tú. Son los "pacos" (policías)", los jueces, el estado, el presidente. El estado opresor es un macho violador. El estado opresor es un macho violador. El violador eras tú. El violador eres tú. Duerme tranquila, niña inocente, sin preocuparte del bandolero, que por tus sueños, dulce y sonriente, vela tu amante carabinero. El violador eres tú. El violador eres tú. El violador eres tú. El violador eres tú."
\end{abstract}

Colectivo Lastesis (2019)

\subsection{Consideraciones iniciales}

Las líneas con que iniciamos este capítulo proceden de la letra del himno feminista "Un violador en tu camino", también conocido como "El violador eres tú", del colectivo

1A sugerencia de las propias autoras de la letra, en cada país y contexto dicha letra se adaptó a la realidad cultural y social correspondiente, sustituyéndose, en el caso de la letra en castellano interpretada en diversas ciudades españolas, la palabra "pacos"(un término informal para denominar a los policías en Chile) por "fachas" (su equivalente en castellano peninsular). 
chileno Lastesis, que se hizo viral tras las manifestaciones masivas de 2019 en que el pueblo chileno inundó las calles para reclamar justicia social. En una de estas manifestaciones, que tuvo lugar en Valparaíso el 20 de noviembre de 2019, se realizó la primera performance o "intervención”, como Lastesis prefieren llamar a sus actos (se representó primero en la plaza Aníbal Pinto, en la plaza Victoria y frente a la Segunda Comisaría de Carabineros de Chile) de esta poderosa forma de visibilización de problemas tan graves como la violación o el feminicidio, con mujeres de ojos vendados cantando/rapeando al unísono y ejecutando la ya conocidísima coreografía que después sería replicada en muchas otras ciudades de Chile y del resto del mundo.

Las ideólogas de esta iniciativa, quienes han sido incluidas entre las 100 personalidades más influyentes del mundo en 2020 por la revista Time (Tolokonnikova, 2020), fueron las artistas/artivistas Dafne Valdés, Paula Cometa, Sibila Sotomayor y Lea Cáceres quienes, según explicaron al diario El País en una entrevista (Rodríguez, 2019), se propone llevar a escena las tesis teóricas feministas para difundir su mensaje reivindicativo, inspiradas por pensadoras como la antropóloga feminista Rita Segato. Esta experta en la temática de la violencia que se ejerce contra las mujeres defiende la desmitificación del violador como un sujeto que ejerce la acción de violar por placer sexual, pues "la violación no es un acto sexual, es un acto de poder, de dominación, es un acto político" (Segato, 2019), con lo que la violación deja de ser considerada un problema personal y pasa a ser entendido como el problema y la lacra social que es. La imagen de abajo muestra el movimiento coreográfico del que puede considerarse el clímax de la canción-poema "Un violador en tu camino": el momento en que todas las voces se unen para denunciar 
al único y exclusivo culpable de que una violación, se produzca, sean cuales sean las condiciones en las que se produzca: "el violador ERES TÚ":

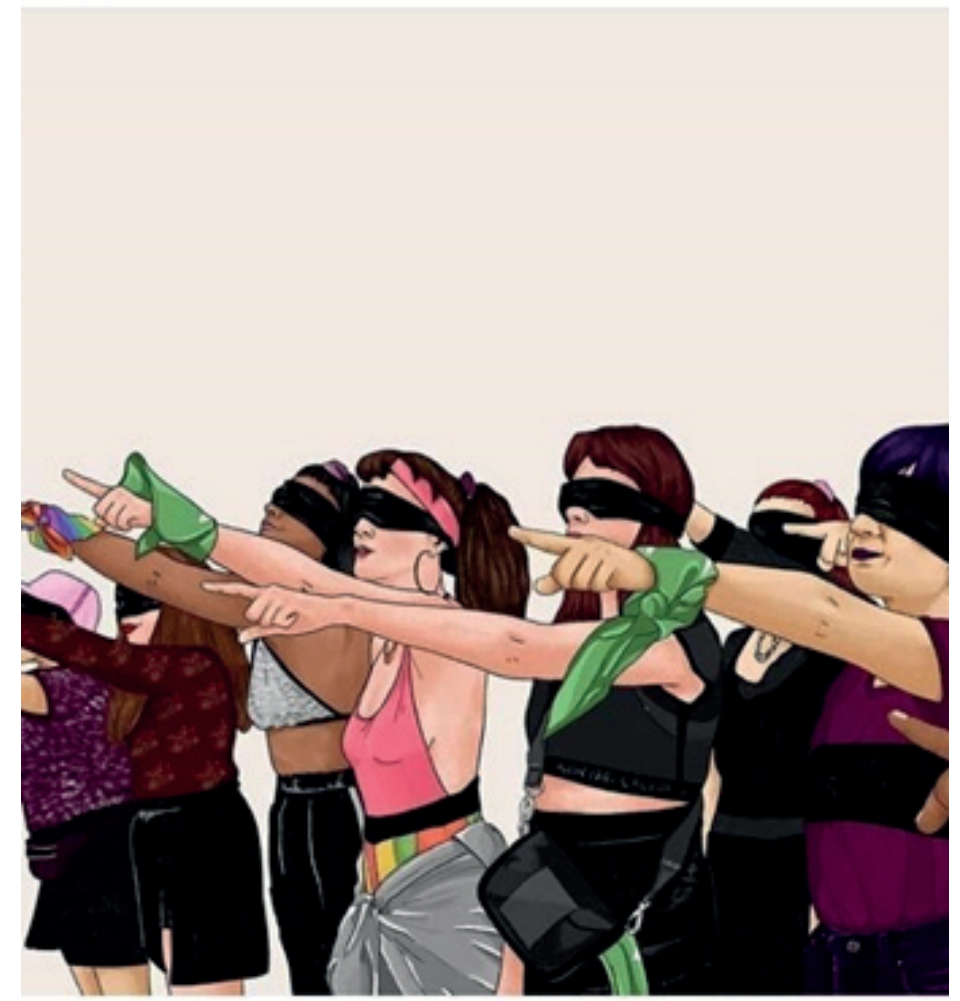

Fuente: DenLesDen, CC BY-SA 4.0, https://creativecommons.org/licenses/by-sa/4.0, Wikimedia Commons, 2021.

Figura 1. Mujeres enmascaradas interpretando "Un violador en tu camino".

Iniciamos este volumen, el tercero de la colección, que sucede al publicado en 2019, con este contundente himno feminista de las artivistas Lastesis, que nos muestran que el arte popular puede ayudar a acicatear la lucha por la justicia para las mujeres a nivel global. El capítulo introductorio del volumen precedente, Educación multidisciplinar para la igualdad de género: perspectivas traductológicas, ecoartísticas, socio-educativas y jurídicas (2019), mostraba en su portada una serie de sustantivos masculinos eclipsando la palabra "mujer" con la intención de transmitir la invisibilización de la labor de la mujer a lo largo de la historia occidental, tanto en la ciencia y el conocimiento como en cargos de poder, así como en los ámbitos religioso, social, laboral, artístico, etc. 


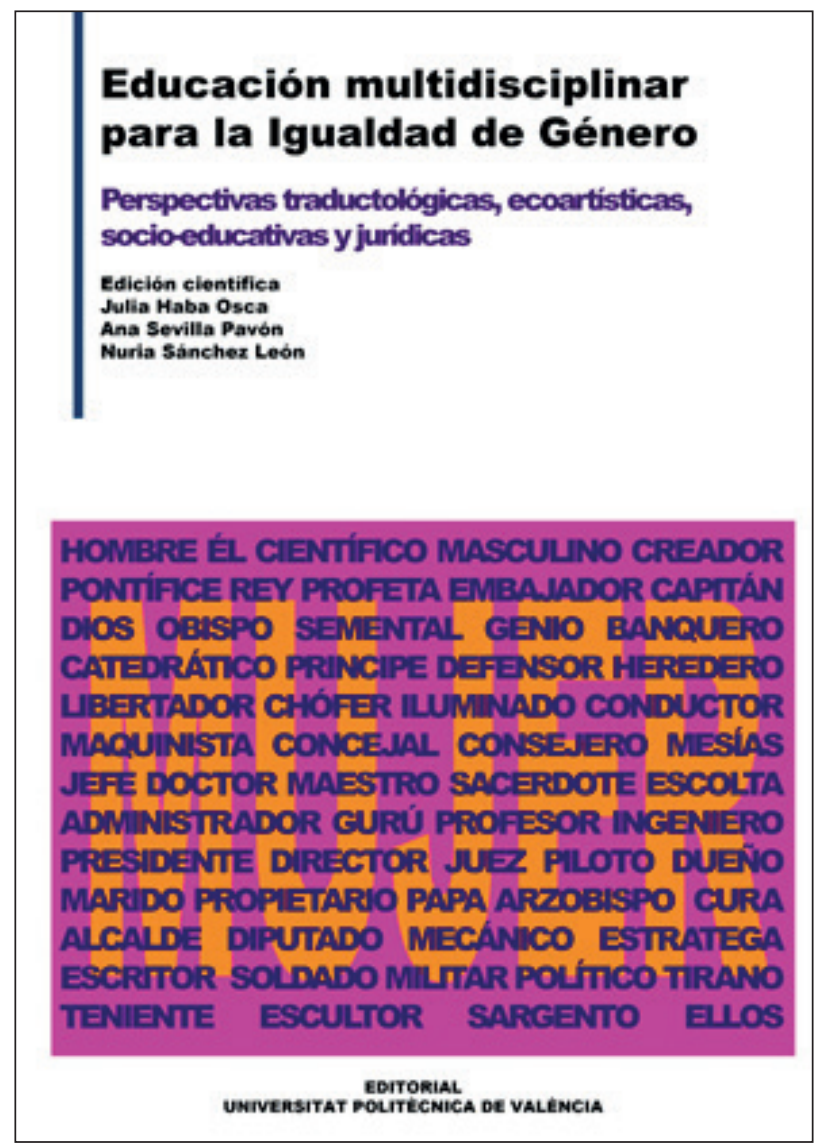

Figura 2. Portada del volumen 2 de Educación multidisciplinar para la igualdad de género. Perspectivas traductológicas, ecoartísticas, socioeducativas y jurídicas (Eds.

N. Sánchez León, A. Sevilla Pavón y J. Haba Osca, 2019), diseñada por Nuria Sánchez León.

El presente volumen continúa el camino iniciado por las reflexiones e investigaciones en torno a la igualdad de género de las dos ediciones que lo preceden, aunque aportando nuevas perspectivas. En este caso, con la portada se propone hacer énfasis en la cuestión lingüística como reacción a la diversidad de perspectivas en cuanto al lenguaje inclusivo, pues en la actualidad conviven diversas posturas y guías de lenguaje. En la presente edición, además de recoger diversas iniciativas y ejemplos de buenas prácticas en el campo de la igualdad de género y la educación multidisciplinar en muy variadas vertientes, se dedicará un capítulo precisamente a este abanico de opciones lingüísticas. 
Un hecho destacable es que en la Universitat de València (UV), se está apostando, por un lado, por implementar los Objetivos de Desarrollo Sostenible (ODS) de la Agenda 2030 de la UNESCO $(2018,2015,2000,1994)$ entre todo su personal (tanto docente como de administración y servicios), alumnado y prácticas, con especial énfasis en el ODS 5, "lograr la igualdad entre los géneros y empoderar a todas las mujeres y las niñas". Por otro lado, la UV ha incluido también entre sus líneas estratégicas el apoyo a las iniciativas de espíritu emprendedor de la población universitaria en general y, en particular, de las mujeres, canalizando este objetivo a partir de acciones concretas como las que se llevan a cabo desde UVEmprén.

En el marco del programa UVEmprén se están apoyando diferentes iniciativas, todas ellas lideradas por mujeres. Una de estas iniciativas es el proyecto Youth Entrepreneurship for Society (YES) Lab ${ }^{2}$, que persigue fomentar la innovación y emprendimiento social en el alumnado y profesorado y la capacitación de los estudiantes para desenvolverse con éxito en entornos laborales internacionales e interculturales a través del desarrollo de competencias del siglo XXI (Partnership for 21st Century Skills, 2009) que incluyen: emprendimiento social y competencias digitales, lingüísticas, interculturales e interpersonales. YES Lab proporciona apoyo a la comunidad universitaria en materia lingüística en relación al emprendimiento social, mediante la formación a través de píldoras educativas sobre diversas temáticas en torno al emprendimiento y la asesoría a través de reuniones con el alumnado que participa en convocatorias de emprendimiento; y, por otro, la simulación e inmersión en entornos profesionales a través de mundos virtuales tridimensionales, en colaboración con la población universitaria de los diversos países participantes, a través del intercambio virtual. En el proyecto se tiene en cuenta la perspectiva de género y el fomento de la igualdad entre hombres y mujeres, mediante el uso de lenguaje inclusivo; una participación equitativa en el proyecto de mujeres y hombres, de alumnado; la representación, en las simulaciones en mundos virtuales tridimensionales de mujeres en labores y empleos relacionados con la ciencia, la tecnología y el tejido empresarial, ocupando puestos directivos y de amplia relevancia y responsabilidad; y, sobre todo, mediante el énfasis que el proyecto YES Lab, en línea con la estrategia global de la UV señalada anteriormente, pone en el ODS 5, relacionado con la igualdad de género, a la hora de guiar al alumnado en la ideación y creación de sus iniciativas de emprendimiento social.

Por nuestra parte, la modesta aportación que, como cada año, realizamos a la educación por la igualdad de género es la organización anual de las Jornadas Multidisciplinares de Educación en Igualdad de Género, que cuentan con el apoyo de la Unitat d'Igualtat y de la unidad de emprendimiento UVEmprén, de la Universitat de València. Este compendio aglutina una selección de las ponencias de los participantes en la $\mathrm{V}$ jornada, celebrada en

2Las autoras quisieran expresar su agradecimiento a UVemprén: Oficina de políticas de excelencia de la Universitat de València y a Santander Universitas por su apoyo al proyecto Youth Entrepreneurship for Society: saying YES to social innovation through a university lab (YES LAB, ref. UV-OPEX_BERKELEY20-1368230) durante el período 2020-2021, dirigido por Ana Sevilla-Pavón. Para más información, véase: https://www.uv.es/uv-entrepreneurships/en/yes-lab.html 
2020 y que sigue mostrando un gran interés de asistencia, llegando a rondar la centena de participantes inscritos e inscritas. Agradecemos desde aquí en especial su participación a nuestras invitadas para las ponencias plenarias, así como a los y las participantes en las sesiones paralelas. Todas estas personas, junto a los comités organizador y científico, han hecho posible que presentemos este tercer volumen con una selección de ponencias que pretenden aportar diversas perspectivas en torno a la igualdad de género actual desde tan variadas disciplinas como la lingüística, literatura y traducción; la didáctica; las ciencias de la salud; la ingeniería; y el teatro.

El presente volumen está dividido en tres partes. La primera se centra en las perspectivas de género desde la lingüística, la literatura y la traducción. La segunda parte trata temáticas relacionadas con didácticas, sanitarias y científico-tecnológicas. Por último, la tercera y última parte se ocupa de perspectivas sociales, psicológicas y artístico-teatrales.

Así, tras este primer capítulo, que hace las veces de introducción del libro, pasamos al siguiente capítulo de la primera parte (Parte I: Perspectivas lingüísticas, literarias y traductológicas), titulado "Sexismo lingüístico, el variacionismo para fomentar la igualdad de género", del Dr. Manuel Rodríguez Peñarroja, profesor e investigador del Dept. d'Estudis Anglesos de la Universitat Jaume I. El autor comienza con un repaso a las reivindicaciones feministas que se originaron a mediados del siglo XVIII, las cuales considera que siguen latentes en la actualidad, centralizando sus esfuerzos en la consecución de derechos sociales, la integración y equidad entre géneros (Rodríguez-Peñarroja, 2021, en este volumen). Rodríguez-Peñarroja parte de la concepción del lenguaje como una herramienta para visibilizar y conformar realidades, y tiene en cuenta el efecto de las sociedades patriarcales y el androcentrismo en el uso del lenguaje, para resaltar la importancia y necesidad de una reforma en el sistema o código lingüístico. Con este fin, el autor señala cómo diferentes instituciones han elaborado guías para un uso no sexista del lenguaje que recogen numerosos ejemplos de sexismo lingüístico, así como recomendaciones y alternativas para evitar estos usos. Y es precisamente el objetivo de este capítulo la revisión de los principales usos sexistas del lenguaje identificados en las guías elaboradas en universidades públicas en la Comunidad Valenciana, así como las alternativas que se proponen para hacer un uso más inclusivo del lenguaje. Del mismo modo, entendiendo que este tipo de guías ha centrado su uso en contextos académicos e institucionales, el autor describe modelos de cambio y variación lingüística que muestran la funcionalidad, adaptabilidad y dinamismo del lenguaje, teniendo en cuenta diferentes necesidades y comunidades de hablantes. Este cambio de perspectiva hacia el hablante, de acuerdo con el autor, debe ir acompañado del estudio sociolingüístico de los aspectos ideológicos ligados al lenguaje y a la producción de estereotipos que siguen ralentizando la consecución de la equidad de género a nivel lingüístico y social. Como complemento a este capítulo quisiéramos resaltar el reciente uso de la "e" la "@" o la "x" para formar sustantivos "más inclusivos" según ciertos sectores de la ciudadanía. A este respecto, las propias guías de lenguaje desaconsejan usar la x o la @ porque no son formas aceptadas por la RAE. Sin embargo, sí recomiendan otras medidas, como el uso de sustantivos colectivos para evitar desdoblamientos, que la RAE considera también innecesarios y 
limitados (RAE, 2020, p. 64). La posición de la RAE es clara según el texto: Informe de la Real Academia Española sobre el uso del lenguaje inclusivo y cuestiones conexas de enero de 2020, donde dice:

"En algunos ámbitos se ha difundido la idea de que el masculino genérico es una herencia del patriarcado y su uso es lesivo para la mujer, por lo que se ha de evitar en el discurso.

Sin embargo, esta tesis carece de fundamento. El masculino genérico es anterior al masculino específico y su génesis no se halla relacionada con el androcentrismo lingüístico." (2020, p. 53)

Más claramente expresa en Twitter en julio de 2019 su posición al respecto del lenguaje inclusivo en general: "Esta institución no avala el llamado «lenguaje inclusivo», que supone alterar artificialmente el funcionamiento de la morfología de género en español bajo la premisa subjetiva de que el uso del masculino genérico invisibiliza a la mujer." Por tanto, el uso de la "e" tampoco ha sido aceptado desde el punto de vista lingüístico. Según expresa en Twitter el 1 de abril de 2019, "El uso de la letra «e» como supuesta marca de género inclusivo es ajeno a la morfología del español, además de innecesario, pues el masculino gramatical (en este caso «todos») ya cumple esa función como término no marcado de la oposición de género." El tema es campo fértil para el debate según la misma RAE expresa (2020, p. 51), y la ciudadanía se plantea que si se han aceptado otras transformaciones del lenguaje por presión del número de hablantes, ¿no ocurrirá lo mismo con estas propuestas? Por ahora, el uso de la "e" en la formación de sustantivos "más inclusivos" parece denotar más una posición política que una corrección lingüística con posibilidades de asentarse.

Seguidamente, el tercer capítulo, "La voz de la Sirena de Carme Riera. Una lectura hipertextual", de la Dra. Elisabet Contreras Barceló, profesora e investigadora del Dept. d'Educació Lingüística i Literària, i Didàctica de les Ciències Experimentals i la Matemàtica de la Universitat de Barcelona, nos trae una propuesta que parte de la teoría de la hipertextualidad y la intertextualidad de Genette (1989), según la cual se establecen una serie de relaciones entre las distintas obras de la historia de la literatura como un hecho inevitable, en el que personajes, tramas y argumentos devienen lugares comunes en los procesos creativos de reescrituras. Por esta razón, como señala la autora el proceso de recepción completa de las obras literarias requiere la activación de una serie de mecanismos para reconocer dichos elementos hipertextuales, a partir de la propia experiencia literaria. Por ello, es necesaria la lectura reiterada de modelos, estructuras, argumentos y personajes, pues dicha práctica les permite ampliar su bagaje literario y les enseña a reconocer dichos elementos, y a establecer relaciones entre estos y lecturas anteriores, lo cual a su vez, favorece su competencia literaria. A partir de estos postulados, la autora aborda el análisis de la obra mencionada. Se trata de una reescritura juvenil de las populares Sirenita de Andersen y La Sirenita de Walt Disney. Contreras Barceló destaca que, a pesar de que el principal hipotexto es el de Andersen, ni la autora ni el lector pierden de vista la popularizada versión cinematográfica de Disney en la configuración del personaje y que Contreras, a través de algunos cambios y la introducción de nuevos elementos, 
hace una pertinente actualización de los cuentos de hadas y sus finales felices, desde una perspectiva feminista.

Esta primera sección concluye con el Capítulo 4, "Cabrera Infante en boca de Suzanne Jill Levine: Tres Tristes Tigres en clave feminista", escrito por el Dr. Robert MartínezCarrasco y Eva Peñarrocha, del Dept. de Traducció i Interpretació de la Universitat Jaume I. Partiendo de la reflexión de que la lengua y, por ende, la traducción, son herramientas de transformación social, que no puede abstraerse de lo cultural, lo académico y lo político y que apuntalan, de una manera u otra, los procesos colectivos de significación que dan forma a nuestra realidad más inmediata. Estos autores señalan las asimetrías de poder presentes en la traducción, así como las fidelidades encontradas a las que se enfrenta quien traduce, sean hacia quien encarga la traducción, hacia una misma o hacia una hipotética audiencia que solo puede acceder a ciertos discursos a través de la traducción. Se destaca- también que en este tercer caso es donde quien traduce tiene la oportunidad de perpetuar ciertas prácticas y actitudes o, por el contrario, posicionarse ideológicamente contra determinados discursos y prácticas socialmente establecidas. Partiendo de esa base, se profundiza en el posicionamiento de la traductora a través del análisis de la obra traducida de Suzanne Jill Levine, en particular de su traducción al inglés de la obra Tres tristes tigres, de Guillermo Cabrera Infante. Basándose en estrategias que permiten la "reescritura en femenino" de la obra original (compensación o suplementación, metatextualidad, secuestro y coautoría), el capítulo profundiza en los lazos de solidaridad interfemeninos con que un grupo de autoras y traductoras en el Quebec de los años 80 y 90 (Barbara Godard, Suzanne Jill Levine, Luise von Flotow, Sherry Simon o Susanne Lotbinière) se propuso subvertir el monólogo del discurso patriarcal dominante planteando, así, cómo desmantelar el patriarcado arraigado en la palabra escrita, en el marco de las primeras teorías feministas de la traducción.

En la segunda parte, (Parte II: Perspectivas didácticas, sanitarias y científico-tecnológicas), encontramos en primer lugar el Capítulo 5, "El cómic y el álbum ilustrado como recursos para la educación en la diversidad de género y afectivo-sexual", de Andrés Giner Latorre, profesor de Lengua castellana y Literatura en el IES Font de Sant Lluís, situado en la ciudad de Valencia. El autor (Giner Latorre, 2021, en este volumen) se remonta a la elaboración de la ley educativa LOGSE (1990) para ilustrar cómo se ha venido intentando conseguir una igualdad formal en todos los centros educativos de nuestro país, especialmente gracias a la atención de la transversalidad o el conocido como currículo oculto. No obstante, como señala el autor, a pesar del esfuerzo por cubrir todos los ámbitos en materia de igualdad, el reconocimiento de las personas LGTBIQ+ sigue siendo un reto para la coeducación. Por ello, en los últimos años, se intenta visibilizar en las aulas para, basándose en la teoría de la performatividad de Butler (Butler, 2009, 2007, 2006a, 2006b, 2003), promover la importancia de que el individuo reconozca la necesidad de construirse como sujeto a través del lenguaje. Por tanto, el autor señala el relevante papel de la formación lectoliteraria y, especialmente, de las obras gráficas (cómic, álbum ilustrado) en el fomento de experiencias multisensoriales que propicien al alumnado una empatía afectiva -así como un reto intelectual- en un contexto de gus- 
to estético. Por ello, este trabajo se propone la creación de una biblioteca de colores susceptible de instalarse en todos los niveles educativos: desde la etapa Infantil hasta Bachillerato, teniendo como referencia las competencias en cada etapa y el currículum, de tal manera que esta biblioteca se introduzca en dicho currículum de manera conjunta con el temario de algunas asignaturas. Entre la selección de álbumes y cómics o novelas gráficas, el autor distingue cinco bloques temáticos para su clasificación: la "salida del armario" o definición de la identidad; la ruptura con los estereotipos tradicionales de la heteronorma; la diversidad de género, tratada de manera subtextual o con el concepto de cuqui-queer; la expresión de género; y, por último, el contexto histórico-social, para acercar la historia social de la comunidad LGTBIQ+. De este modo, como señala Giner Latorre, se dota al docente una serie de recursos de fácil incorporación en el aula para garantizar la visibilidad, reconocimiento e inclusión de la diversidad afectivo-sexual, de género y familiar existente en nuestra sociedad actual.

A continuación, el Capítulo 6, "La llegada a la otra cara de la Luna: eclipsadas por los hombres", de la Dra. Rocío Domene-Benito, profesora e investigadora del Depto. de Didáctica de la Lengua y la Literatura de la Universidad de Valladolid, reivindica las caras femeninas de uno de los mayores hitos de la historia: la llegada de la humanidad a la Luna, cuyo quincuagésimo aniversario se celebró en 2019. Como nos recuerda la autora (Domene-Benito, 2021, en este volumen), la publicidad de la época solo ensalzó la figura de Neil Amstrong, ignorando el papel fundamental desempeñado por mujeres como la científica Margaret Hamilton y las conocidas como "Las Computadoras del Área Oeste": Katherine Johnson, Mary Jackson y Dorothy Vaughan, quienes contribuyeron decisivamente en la consecución de este hecho histórico. Domene-Benito plantea una aproximación histórica al papel que desempeñaron estas científicas y a su reciente aparición en la literatura infantil y juvenil a través de álbumes ilustrados, lo cual le sirve a la autora para esgrimir unas referencias al álbum ilustrado como recurso didáctico para la enseñanza/ aprendizaje de lenguas extranjeras en la etapa de educación primaria. Una vez analizados dichos materiales a través de diversos juegos metafóricos y hechos históricos con el astro lunar como protagonista, tanto en su concepción estrictamente científica como en la simbólica como elemento romántico, la autora plantea una propuesta didáctica que incide en la necesidad de la combinación del lenguaje narrativo y visual con el objeto de fomentar el desarrollo del pensamiento crítico, la imaginación y la creatividad desde edades tempranas a través de la literatura y la recuperación de la historia en femenino. Roció Domene-Benito concluye con la reflexión en torno a la necesidad e importancia de este tipo de propuestas que favorecen la inclusión de la perspectiva de género/sexo en la educación literaria intercultural y feminista a través de la lectura dialogada y de la promoción de actividades interdisciplinares (Domene-Benito, 2021, en este volumen).

Seguidamente, encontramos el Capítulo 7 "Proyecto Girls4STEM: fomento de vocaciones científico-tecnológicas desde la igualdad y la diversidad", de la Dra. Silvia Rueda, la Dra. Emilia López-Iñesta, Carmen Botella-Mascarell, Joaquín Pérez, Esther de Ves, Xaro Benavent, Anabel Forte, Esther Dura, Sandra Roger, Cristina Portalés, Daniel García-Costa y Paula Marzal, de los departamentos de Ingeniería Informática - ETSE, 
de Didàctica de la Matemàtica, Facultat de Magisteri, d'Enginyeria Electrònica, ETSE, d'Estadística i Investigació Operativa, y de la Facultat de Matemàtiques, d'Enginyeria Química, ETSE, todos ellos de la Universitat de València. Los autores y autoras inician su capítulo destacando el importante papel que los centros educativos desempeñan en el desarrollo personal de niños y niñas, destacando la influencia de la educación superior en mostrar la relación que existe entre las profesiones de las áreas conocidas por sus siglas en inglés como STEM (Science, Technology, Engineering and Mathematics, es decir, Ciencias, Tecnología, Ingeniería y Matemáticas) y en la generación de beneficios a la sociedad, así como de cara a la visibilización de referentes femeninos reales y de proximidad que se han formado y desempeñan su labor profesional en disciplinas STEM (Rueda et al., 2021, en este volumen). A continuación, presentan el proyecto Girls4STEM, una iniciativa de la Universitat de València que tiene un amplio rango de público meta, específicamente alumnado de educación primaria y secundaria (con edades comprendidas entre 6 y 18 años). En ese rango de edad, tal y como destacan los autores y autoras, es esencial actuar para fomentar vocaciones científico-tecnológicas, siendo los otros pilares fundamentales del entorno de actuación e influencia en el desarrollo de los niños y niñas su familia y el profesorado de institutos y colegios, con el apoyo del profesorado universitario. Así, tal y como relatan los/las autores y autora de este capítulo, el proyecto Girls4STEM, que cuenta con el apoyo y participación de instituciones, empresas y agentes regionales, tiene como valor principal la interacción entre estudiantes preuniversitarios y expertas profesionales en STEM, lo cual constituye una estrategia que contribuye a visualizar el impacto social de las disciplinas STEM. Asimismo, Girls4STEM se alinea con los Objetivos de Desarrollo Sostenible (ODS) de la Agenda de Desarrollo Sostenible para 2030 de la UNESCO (UNESCO, 2015). Específicamente, el proyecto persigue el empoderamiento de las mujeres (ODS 5, relacionado con la igualdad de género), la progresiva incorporación de la igualdad de género (ODS 5) para garantizar una educación de calidad (ODS 4, relacionado con la educación de calidad) y la reducción de las desigualdades (ODS 10), utilizando las Tecnologías de la Información y la Comunicación (TIC) como elemento transversal imprescindible para conseguir el empoderamiento de la mujer en la futura Sociedad Digital (Rueda et al. 2021, en este volumen).

Por su parte, el Capítulo 8, "Enfermería y Género", escrito por las Dras. Francisca Esteve Claramunt y Concepción Martínez Martínez, del Departamento de Medicina y Enfermería de la Universidad Europea de Valencia, se inicia recordándonos que la base y centro de la enfermería es el "cuidado" y que, para que los cuidados proporcionados en cada una de estas situaciones sean satisfactorios, debemos considerar a la persona de forma integral, teniendo en cuenta tanto la esfera física, psíquica como social (Esteve Claramunt y Martínez Martínez, 2021, en este volumen). Para ello, como señalan las autoras, los trabajadores del campo de la enfermería ponen en práctica dichos cuidados de forma profesional, haciendo uso de una metodología y de una taxonomía sistemática, conocidas como "Proceso de Atención de Enfermería" y "NANDA", respectivamente. Las autoras siguen una visión histórica de la evolución de la profesión enfermera, resaltando cómo a finales del siglo XVIII y principios del XIX existía una falta de enfermeras cualificadas 
que se hicieran cargo de las personas enfermas, motivo por el cual se hicieron necesarias las reformas sanitarias, que no fueron realizadas únicamente por hombres, puesto que grandes mujeres lucharon para conseguir mejorar las condiciones de los más desfavorecidos. Entre ellas, se incluyen Elisabeth Fry y Florence Nightingale en Gran Bretaña, y Concepción Arenal en España. Además, el análisis de la evolución de los estudios de enfermería en España llevado a cabo por las autoras permite observar diversos logros en cuanto a la consideración de la profesión: en primer lugar, se pasó de la denominación de "Auxiliar Técnico Sanitario" a "Diplomado Universitario de Enfermería"; además, en 2005 los y las profesionales de enfermería en España pasaron de la Diplomatura al Grado , lo cual amplió sus posibilidades de acceso a estudios de postgrado como son los programas de máster y doctorado. Al analizar la evolución y desarrollo de la enfermería, Esteve Claramunt y Martínez Martínez aprecian una marcada visión de género que ha contribuido a que se haya mantenido la feminización de la profesión hasta nuestros días. Por ello, las autoras destacan que el hecho de observar la enfermería desde una perspectiva de género es investigar, por un lado, cómo los estereotipos que tradicionalmente se han atribuido a la mujer han afectado al desarrollo histórico de la profesión y, por otro lado, las consecuencias que ha tenido sobre ella el sistema de patriarcado (Esteve Claramunt y Martínez Martínez, 2021, en este volumen).

Finalmente, la tercera y última parte, Parte III: Perspectivas sociales, psicológicas y artístico-teatrales, incluye los siguientes capítulos:

El Capítulo 9, "Las sinergias para la inclusión de la perspectiva de género universitario" de las Dras. Genoveva Ramos Santana y Amparo Pérez Carbonell, del Depto. de Métodos de Investigación y Diagnóstico en Educación de la Universitat de València, que se centra en una serie de proyectos llevados a cabo en aras de la inclusión de la perspectiva de género (PG) en la docencia universitaria como responsabilidad social y educativa (Ramos Santana y Pérez Carbonell, 2021, en este volumen). Se trata de dos proyectos de innovación realizados durante los cursos 2018-2019 y 2019-2020 y financiados por el Servicio de Formación Permanente e Innovación Educativa de la Universitat de València. En ellos se implicó un grupo de 22 docentes de diez titulaciones de esta universidad, todos ellos comprometidos con la inclusión de la PG en la docencia. El quehacer del grupo en dichos proyectos se presenta en este capítulo. Las autoras parten de una metodología mixta, autorreflexiva y colaborativa, para revisar experiencias y estudios previos en distintas bases de datos y analizar las guías para una docencia universitaria con PG de la Xarxa Vives d'Universitats (2018). Seguidamente, el grupo de docentes evalúa la PG inicialmente presente en cada asignatura y participa como comité de personas expertas en el diseño y validación de un cuestionario dirigido al alumnado universitario, el cual pretende explorar la opinión del alumnado sobre la PG en las asignaturas que cursa. Asimismo, el profesorado discute en grupos sobre la PG y las metodologías que la favorecen; desarrolla un proceso de evaluación entre iguales para identificar buenas prácticas a replicar y, gestiona la incorporación de la PG para su docencia futura (Ramos Santana y Pérez Carbonell, 2021, en este volumen). Los resultados referidos por las autoras incluyen: la actualización de las guías docentes y de las referencias bibliográficas de las 
asignaturas con PG; el valor del uso del lenguaje inclusivo; y la identificación de la diversidad de metodologías de enseñanza-aprendizaje (cooperativa, participativa y visual) como elemento idóneo para trabajar la igualdad de género. Además, las autoras llaman la atención sobre la dificultad de hallar recursos y materiales adecuados para aplicar la PG en las asignaturas, así como la necesidad de la formación por parte del profesorado para trabajar por la igualdad en las aulas universitarias. Ramos Santana y Pérez Carbonell (2021) concluyen que todas las actividades realizadas de forma sistemática y las sinergias generadas entre el profesorado han potenciado la inclusión de la PG en la docencia y el compromiso del grupo hacia la igualdad de género, lo cual pone de manifiesto la importancia de planificary gestionar la PG de forma metódica para su integración en las asignaturas y para su transversalidad en la educación superior.

El Capítulo 10, "Fomento de la participación de personas mayores en Perspectiva de Género: una experiencia con agentes activos de cambio social", de las Dras. Julia Haba Osca y Sandra Simó Teufel, del Dept. Filologia Anglesa i Alemanya y del Depto. Psicología Básica de la Universitat de València, respectivamente, llaman desde la Universitat de València a la ciudadanía universitaria para alcanzar los Objetivos de Desarrollo Sostenible que promueve Naciones Unidas en su Agenda 2030. Para ello, despliegan diversos instrumentos docentes, siendo uno de los más destacados el programa "Universitat i Societat", más conocido como UNISOCIETA. Nace en 2019-2020, con motivo de la demanda en la sede de Quart de Poblet de impartir el curso "Perspectiva de Género", un taller de formación piloto para vincular una iniciativa transversal que persigue el cumplimiento de las metas marcadas en la Agenda 2030. De este modo, fue posible la apertura de un espacio para la reflexión y la acción, tomando como base la educación multidisciplinar para la igualdad de género y proyectándolo hacia una consciencia de los objetivos que deben guiar la erradicación de las desigualdades sociales.

Aquella experiencia inicial reunió en un mismo espacio a alrededor de 50 personas mayores (jubilados/as, profesores y profesoras, amas de casa, personal sanitario y personal de servicios del ayuntamiento local) que lograron apropiarse de referentes feministas e interpretarlos en clave de logros de la sociedad a lo largo del tiempo. Las manifestaciones de esta lucha, tanto individual como colectiva, cobran un nuevo valor en la mirada de las personas mayores que forman parte de la comunidad universitaria y que desean exponer su percepción sobre la Perspectiva de Género a nivel local para explicarlo en clave global.

El Capítulo 11, "Moby Dick o el mal amor: violencia de género y obsesión desde el clásico de Melville", del Dr. Daniel M. Ambrona Carrasco, docente del Colegio La Baronía San Antonio Abad de Gilet (Valencia). El capítulo se centra en la obra Moby Dick. El Mal Amor, que la Compañía de Danza Transfermove y la compañía de teatro Arden Producciones estrenaron en 2016 en la Sala Russafa de Valencia a partir de una idea original de Toni Aparisi y del director Chema Cardeña, quienes también protagonizaron la obra junto a Iria Márquez e Iris Pintos. Moby Dick. El Mal Amor. La obra trazaba un paralelismo a partir de la obra de Melville para crear un alegato contra la violencia de género, con 
el objetivo de denunciar la falta de atención, comprensión y apoyo que muchas mujeres sufren en nuestro país debido a la violencia machista y de género (Ambrona Carrasco, 2021, en este volumen). El autor destaca el verdadero equilibrio temático existente entre ambas historias, novela y obra de teatro; y entre la danza y el teatro, así como el modo en que la analogía se llevó a cabo, mediante los diferentes lenguajes presentes en el escenario: pictórico, musical, textual y corporal, todos ellos integrados en un único lenguaje común. La obra formó parte del compromiso social llevado a cabo por Sala Russafa cada temporada y del compromiso del teatro del siglo XXI ante esta grave problemática. Los análisis llevados a cabo por Ambrona Carrasco (2021, en este volumen) ponen de manifiesto que esta obra aprovecha e interrelaciona las herramientas que ofrecen las diferentes expresiones artísticas reunidas sobre las tablas para, sin tapujos ni visiones poéticas, representar las fases que se suceden en este "mal amor" entre Ahab y Blanche, las cuales conducen a un trágico desenlace, similar al del clásico de Melville. El autor concluye con una reflexión en cuanto a cuán necesaria fue esta producción, no solo por su elevado valor escénico y artístico sino, sobre todo, por su valor educativo, su mensaje de denuncia y su intención de advertir y concienciar a los/as espectadores/as (Ambrona Carrasco, 2021).

Y, para finalizar el volumen, el Capítulo 12, "La SubTerránea: teatro poético hecho por mujeres", Dr. Robert March i Tortajada, del Depto. Didàctica de la Llengua i la Literatura de la Universitat de València; y Lucía Sáez, actriz y dramaturga de La SubTerránea, en que el autor y la autora realizan un recorrido a lo largo de la producción escénica de La SubTerránea. Se trata de una compañía de teatro de mujeres fundada en València el año 2013. March i Tortajada y Sáez (2021, en este volumen) centran su atención en la trayectoria de la compañía y, muy especialmente, en sus procesos creativos y su metodología de trabajo. Asimismo, autor y autora incluyen algunos fragmentos dramáticos de sus textos, los cuales les sirven como punto de partida para interrogarse sobre cómo lo poético aparece en sus piezas en la medida en que estas se abordan desde la investigación y la libertad.

Concluimos este capítulo introductorio reiterando nuestro más sincero agradecimiento a la Unitat d'Igualtat de la Universitat de València, que nos ha apoyado desde el inicio de nuestra andadura, así como a la unidad de emprendimiento de la UV UVEmprén, que nos ha apoyado en esta parte del camino. Además, quisiéramos dar las gracias a todas las personas que han hecho posible que este tercer volumen vea la luz: a las autoras y autores, participantes en las sucesivas ediciones de la "Jornada de Educación Multidisciplinar para la Igualdad de Género", revisores/as externos/as y demás miembros del Comité Científico, a la Editorial UPV y a los diferentes organismos e individuos que han creído en el proyecto y han continuado regalándonos su cariño, su paciencia y apoyo incondicionales. 


\subsection{Referencias bibliográficas}

Ambrona Carrasco, D. M. (2021, en este volumen). Moby Dick o el mal amor: violencia de género y obsesión desde el clásico de Melville. En: Julia Haba Osca, Ana Sevilla-Pavón y Nuria Sánchez León (Eds.), Educación multidisciplinar para la igualdad de género: perspectivas lingüisticas, literarias, tecnológicas y artísticoteatrales. Valencia: Editorial Universitat Politècnica de València.

Butler, J. (2009) Performatividad, precariedad y políticas sexuales. AIBR. Revista de Antropología Iberoamericana, 4(3): 321-336.

Butler, J. (2007). El género en disputa. El feminismo y la subversión de la identidad. Barcelona: Paidós.

Butler, J. (2006a). Deshacer el género. Buenos Aires: Paidós.

Butler, J. (2006b). Vida precaria. El poder del duelo y la violencia. Buenos Aires: Paidós.

Butler, J. (2003) Violencia, luto y política. Íconos: revista de ciencias sociales, 17: 8899.

Contreras Barceló, E. (2021, en este volumen). La voz de la Sirena de Carme Riera. Una lectura hipertextual. En: Julia Haba Osca, Ana Sevilla-Pavón y Nuria Sánchez León (Eds.), Educación multidisciplinar para la igualdad de género: perspectivas lingüísticas, literarias, tecnológicas y artístico-teatrales. Valencia: Editorial Universitat Politècnica de València.

Domene-Benito, R. (2021, en este volumen). La llegada a la otra cara de la Luna: eclipsadas por los hombres. En: Julia Haba Osca, Ana Sevilla-Pavón y Nuria Sánchez León (Eds.), Educación multidisciplinar para la igualdad de género: perspectivas lingüísticas, literarias, tecnológicas y artístico-teatrales. Valencia: Editorial Universitat Politècnica de València.

Esteve Claramunt, F. y Martínez Martínez, C. (2021, en este volumen). Enfermería y Género. En: Julia Haba Osca, Ana Sevilla-Pavón y Nuria Sánchez León (Eds.), Educación multidisciplinar para la igualdad de género: perspectivas lingüisticas, literarias, tecnológicas y artístico-teatrales. Valencia: Editorial Universitat Politècnica de València.

Genette, G. (1989). Palimpsestos: la literatura en segundo grado. Madrid: Taurus.

Giner Latorre, A. (2021, en este volumen). El cómic y el álbum ilustrado como recursos para la educación en la diversidad de género y afectivo-sexual. En: Julia Haba Osca, Ana Sevilla-Pavón y Nuria Sánchez León (Eds.), Educación multidisciplinar para la igualdad de género: perspectivas lingüísticas, literarias, tecnológicas $y$ artístico-teatrales. Valencia: Editorial Universitat Politècnica de València.

Haba Osca, J. y Simó Teufel, S. (2021, en este volumen). Fomento de la participación de personas mayores en Perspectiva de Género: una experiencia con agentes activos de cambio social. En: Julia Haba Osca, Ana Sevilla-Pavón y Nuria Sánchez León (Eds.), Educación multidisciplinar para la igualdad de género: perspecti- 
vas lingüísticas, literarias, tecnológicas y artístico-teatrales. Valencia: Editorial Universitat Politècnica de València.

March i Tortajada, R. y Sáez, L. (2021, en este volumen). La SubTerránea: teatro poético hecho por mujeres. En: Julia Haba Osca, Ana Sevilla-Pavón y Nuria Sánchez León (Eds.), Educación multidisciplinar para la igualdad de género: perspectivas lingüísticas, literarias, tecnológicas y artístico-teatrales. Valencia: Editorial Universitat Politècnica de València.

Martínez-Carrasco, R. y Peñarrocha, E. (2021, en este volumen). Cabrera Infante en boca de Suzanne Jill Levine: Tres Tristes Tigres en clave feminista. En: Julia Haba Osca, Ana Sevilla-Pavón y Nuria Sánchez León (Eds.), Educación multidisciplinar para la igualdad de género: perspectivas lingüisticas, literarias, tecnológicas $y$ artístico-teatrales. Valencia: Editorial Universitat Politècnica de València.

Real Academia Española (RAE), (2020) Informe de la Real Academia Española sobre el uso del lenguaje inclusivo y cuestiones conexas. España: Autor.

Real Academia Española (RAE) [@Rae Informa \#duda RAE]. (s.f.). Tweets [Perfil de Twitter]. Recuperado el 10 de mayo de 2021 de https://twitter.com/ RAEinforma?ref src=twsrc\%5Egoogle $\% 7$ Ctwcamp $\% 5$ Eserp\% $\%$ Ctwgr\%5Eauth or

Ramos Santana, G. y Pérez Carbonell, A. (2021, en este volumen). Las sinergias para la inclusión de la perspectiva de género universitario. En: Julia Haba Osca, Ana Sevilla-Pavón y Nuria Sánchez León (Eds.), Educación multidisciplinar para la igualdad de género: perspectivas lingüisticas, literarias, tecnológicas y artísticoteatrales. Valencia: Editorial Universitat Politècnica de València.

Rodríguez, D. (2019). Ellas son las chilenas que crearon 'Un violador en tu camino'. Entrevista a LasTesis de Darinka Rodríguez, El País. Disponible en: https://verne. elpais.com/verne/2019/11/28/mexico/1574902455_578060.html

Rodríguez Peñarroja, M. (2021, en este volumen). Sexismo lingüístico, el variacionismo para fomentar la igualdad de género. En: Julia Haba Osca, Ana Sevilla-Pavón y Nuria Sánchez León (Eds.), Educación multidisciplinar para la igualdad de género: perspectivas lingüisticas, literarias, tecnológicas y artístico-teatrales. Valencia: Editorial Universitat Politècnica de València.

Rueda, S.; López-Iñesta, E.; Botella-Mascarell, C.; Pérez, J.; de Ves, E.; Benavent, X.; Forte, A.; Dura, E.; Roger, S.; Portalés, C.; García-Costa, D.; y Marzal, P. (2021, en este volumen). Proyecto Girls4STEM: fomento de vocaciones científico-tecnológicas desde la igualdad y la diversidad. En: Julia Haba Osca, Ana SevillaPavón y Nuria Sánchez León (Eds.), Educación multidisciplinar para la igualdad de género: perspectivas lingüisticas, literarias, tecnológicas y artístico-teatrales. Valencia: Editorial Universitat Politècnica de València.

Segato, R. (2019). Rita Segato, la feminista cuyas tesis inspiraron 'Un violador en tu camino'. Entrevista a Rita Segato de Mar Pichel, BBC News Mundo, 11 diciembre 2019. Disponible en: https://www.bbc.com/mundo/noticias-50735010 
Tolokonnikova, N. (2020). LASTESIS: The 100 Most Influential People of 2020. Time. Disponible en: https://time.com/collection/100-most-influentialpeople-2020/5888485/lastesis

UNESCO (2018). Sustainable Development. Disponible en: https://www.un.org/ecosoc/ en/sustainable-development

UNESCO (2015). Transforming our world: The 2030 agenda for sustainable development. Disponible en: https://sustainabledevelopment.un.org/content/documents $/ 21252030 \% 20$ Agenda $\% 20$ for $\% 20$ Sustainable $\% 20$ Development $\% 20$ web. pdf

UNESCO (2000). Global forum on Education for All. Final Report. París: UNESCO.

UNESCO (1994). UNESCO Today, 41 series, volume IV. Bonn: UNESCO.

Xarxa Vives d'universitats (2018). Guías para una docencia universitaria con perspectiva de género. Xarxa Vives d'universitats. Disponible en: https://www.vives.org/ coleccio/guies-per-a-una-docencia-universitaria-amb-perspectiva-de-genere/ 


\title{
Capítulo 2 Sexismo lingüístico, el variacionismo para fomentar la igualdad de género
}

\author{
Manuel Rodríguez Peñarroja \\ Department d'Estudis Anglesos \\ Universitat Jaume I
}

\subsection{Introducción}

Podemos definir el uso no sexista del lenguaje como la manifestación de la igualdad de género a nivel lingüístico. Entendemos, pues, que las reivindicaciones feministas que se iniciaron entre 1789-1870 y que siguen latentes en la actualidad han conseguido un cambio social mediante la consecución del reconocimiento de derechos políticos, en especial, el derecho al voto, a la educación y al trabajo. En un contexto más reciente, las reivindicaciones se centran en la igualdad económica, libertad sexual y políticas inclusivas de democratización que propugnan la igualdad en roles de género y una mayor visibilización de la mujer (Yepes et al., 2019). Con estos objetivos, el lenguaje como herramienta de comunicación y transmisión cultural debe desempeñar un papel fundamental en la inclusión del género femenino, adaptándose al contexto social y demandas de las diferentes comunidades de hablantes que abogan por un cambio en la manera de expresarnos.

El principal inconveniente que encontramos es que el castellano es una lengua sexuada, es decir, determinantes, artículos, sustantivos y adjetivos aceptan terminaciones para masculino y femenino, marcando, así, el género gramatical. Desde un enfoque positivista, podríamos decir que el castellano como lengua da voz a ambos géneros. Sin embargo, las diferentes sociedades historiográficamente documentadas han sido reconocidas como machistas y patriarcales, relegando a la mujer a un segundo plano, no solo como ser humano sino también en lo referente al lenguaje. Como consecuencia, diferentes recursos del lenguaje han sido tradicionalmente utilizados en detrimento del género femenino. Por ejemplo, el uso del masculino genérico que designa a hombres y mujeres con un término masculino, las posibles diferencias de significado en las fórmulas de tratamiento 
y el uso de duales aparentes que relegan al género femenino a una relación de subordinación o tienen un significado peyorativo.

Atendiendo a esta necesidad de integración e igualdad, el cambio en el uso del lenguaje para favorecer la inclusión del femenino ha venido acompañado de la elaboración de guías para un uso del lenguaje no sexista. Estos manuales recogen diferentes recursos lingüísticos para visibilizar a la mujer y situarla lingüística y culturalmente en equidad con el hombre. Bosque (2012) señala la proliferación de estas guías, elaboradas a nivel universitario, autonómico, sindical y por otras instituciones, notando la escasa participación de lingüistas y haciendo hincapié en que algunas recomendaciones incumplen, en algunos casos, "las normas de la Real Academia Española y Asociación de Academias (...) varias gramáticas normativas (...) y numerosas guías de estilo" (Bosque, 2012, pág. 1). Debido a la polémica y los arduos debates que está generando esta cuestión, el objetivo principal de este capítulo reside en revisar los fenómenos de cambio y variación lingüística para establecer diferencias y similitudes entre estos y describir cómo pueden ayudar a entender la problemática y el tiempo necesario para la adecuación no solo del sistema lingüístico sino también de la realidad o realidades que establecemos mediante el uso del lenguaje. Con este propósito, revisaremos brevemente la teoría feminista y la metáfora de las olas para describir el panorama histórico y actual del feminismo como movimiento social, de una manera general. A continuación, nos centraremos en los problemas principales del lenguaje y las alternativas propuestas en las guías del uso no sexista del lenguaje en una selección de universidades públicas valencianas ${ }^{3}$. Por último, expondremos una serie de conclusiones que implican cambios en la conceptualización del sexismo lingüístico, subrayando la importancia de generar herramientas que abarquen a diferentes comunidades de hablantes en contrapartida a la limitación del alcance de la reforma lingüística a instituciones o entes académicos.

\subsection{Cambio lingüístico y necesidad expresiva}

La lingüística recoge diferentes procesos que describen los cambios o variaciones en el uso del lenguaje, como el que nos atañe en la actualidad. El término más general es el de cambio lingüístico, que implica un proceso diacrónico de modificación del sistema lingüístico a nivel fonético-fonológico, léxico-semántico y morfosintáctico. Tradicionalmente, este fenómeno puede responder a una necesidad de funcionalidad del lenguaje o estar generado con una finalidad en el mismo. Esta dicotomía antepone puntos de vista de lingüistas como Saussure y Coseriu. Para Saussure (1916), el entendimiento del sistema lingüístico por parte del hablante es inmutable, es decir, el lenguaje es un conocimiento estático en la mente del hablante. Como consecuencia, el origen de los cambios no reside

\footnotetext{
3Las guías consultadas son las siguientes: Guía de tratamiento no sexista del lenguaje administrativo fundación Isonomia, Universitat Jaume I (2016). Guía de tratamiento no sexista de la información y la comunicación en la Universitat Jaume I (2010). Guía para un discurso igualitario en la Universidad de Alicante (2011). Guía de uso para un lenguaje igualitario (castellano) Universitat de València (2012). Buenas prácticas para una comunicación inclusiva, unidad de igualdad, Universitat Politècnica de València.
} 
en el propio sistema, pues no se puede otorgar una intencionalidad a un sistema, sino que provienen del exterior, sin negar que puedan tener un efecto en el sistema. Por su parte, Coseriu, aunque coincide con Saussure en que el sistema lingüístico carece de voluntad, da una explicación más funcional al cambio lingüístico, ya sea producido tanto por el potencial creativo de los hablantes en su uso de la lengua, como por la naturaleza finalista en el cambio lingüístico: "la lengua cambia para seguir funcionando como tal" (Coseriu, 1973, pág. 30) y adaptarse a la “existencia de variaciones, innovaciones y reanálisis (...) y por su transmisión tradicional” (Mendivil-Giró, 2010, pág. 117).

Coseriu (1973) también señala el cambio por necesidad expresiva que da lugar a la innovación. Tal y como apunta Lass (1997), la comunidad de hablantes puede adoptar y difundir los cambios por prestigio social o mera moda, lo que se puede identificar con motivos culturales. Son estos motivos los que hacen que la perspectiva del lenguaje que adopta Coseriu se centre en su estudio como fenómeno cultural y no solo como un sistema en la mente de los hablantes. Así pues, se puede entrever una concepción dinámica del lenguaje cuando afirma que "la lengua no es dinámica porque cambia, sino que cambia porque su naturaleza es dinámica” (Coseriu, 1973, pág. 270) y se debe ajustar a las nuevas necesidades de los hablantes. Mendivil-Giró (2010) concluye que el cambio lingüístico se puede explicar mediante la relación de la intencionalidad del hablante y su creatividad, invención y libertad en el uso del lenguaje, como propone Coseriu. Sin embargo, enfatiza que el cambio lingüístico se puede atestiguar sincrónicamente mediante la creación o introducción de nuevos vocablos, así como en el uso de palabras ya existentes con un nuevo significado y diacrónicamente mediante fenómenos más complejos, resultado de la evolución del lenguaje per se. El autor ejemplifica su teoría mediante procesos tales como los cambios estructurales en el orden de las palabras y el desarrollo y decadencia de un sistema de casos (Lass, 1997; Lightfoot, 1999), y pone como modelo paradigmático la evolución del egipcio como lengua flexiva en sus orígenes que pasó a ser aislante, luego aglutinante para volver a ser flexiva (Hodge, 1970; Mendivil-Giro, 2010).

Sería imprudente hablar sobre cambio lingüístico vinculado al uso no sexista del lenguaje. Sin embargo, tal y como veremos más adelante, algunos recursos sintácticos recomendados para evitar el sexismo lingüístico, como son el uso de la voz pasiva, la pasiva refleja y otras construcciones impersonales, implican cambios a nivel estructural del lenguaje en detrimento de otras construcciones gramaticales. A nivel léxico y morfológico, se sugiere el uso de sustantivos genéricos, colectivos y la creación de cargos o puestos en ocupaciones para ambos géneros mediante el sistema de derivación del castellano, siempre y cuando sea posible. Todos estos cambios en el uso del lenguaje, aunque propios del mismo, no habían tenido una funcionalidad relacionada con la igualdad de género hasta nuestros días y, posiblemente, podrán ser estudiados bajo una perspectiva sincrónica en el futuro y, tal vez, diacrónica a más largo plazo. 


\subsection{Variacionismo, pragmatización y gramaticalización}

La variación lingüística es también un fenómeno que acarrea cambios en el uso del sistema lingüístico, pero el proceso de cambio y su estudio se basa en la teoría social (Coupland, 2001) y categorías sociales que se estratifican en torno a factores geográficos (variación diatópica), socioculturales (variación diastrática), contextuales e históricos (variación diacrónica), y funcionales o de registro (variación diafásica) (Blas-Arroyo, 2003; 2005). Por tanto, los estudios de variación lingüística se centran en las modificaciones o variaciones lingüísticas, prestando atención al hablante o comunidad de hablantes (Labov, 1972) y las variables anteriormente descritas, así como la edad, sexo, clase social y nivel educativo. Podemos deducir, pues, que la variación lingüística, a diferencia del fenómeno de cambio lingüístico, adopta una postura sincrónica que relaciona el cambio en el sistema lingüístico con diferentes grupos de hablantes estratificados por rasgos específicos en un periodo de tiempo determinado, es decir, aporta una perspectiva sociolingüística y per se sincrónica de este cambio.

Teniendo en cuenta el énfasis en las comunidades de hablantes y su uso del lenguaje como eje para el estudio de la variación lingüística, Ridruejo (2002) diferencia entre cambio pragmático o pragmatización y lexicalización o gramaticalización. La distinción reside en la funcionalidad del cambio, ya que "un posible cambio pragmático puede consistir en que una regla del código que no suponía una función pragmática pase a desempeñarla, o bien, al contrario que una regla previamente pragmática deje de actuar teniendo esta función.” (Ridruejo, 2002, pág. 97) Por ejemplo, el uso de sufijos diminutivos para establecer relaciones de afectividad y no de disminución o reducción (Alonso, 1967; Noverón, 2005). El autor describe tanto similitudes como diferencias en estos dos cambios, subrayando la importancia, en ambos procesos, del progreso hacia una mayor subjetivización y funcionalidad del lenguaje, generando cambios de significado o semánticos. Partiendo del proceso básico de comunicación como la transmisión (codificación y decodificación) de un mensaje en un sistema inteligible por el emisor y receptor, no es solo el código y las inferencias por parte del receptor, sino también la situación comunicativa, así como factores extralingüísticos que dan significado a la comunicación lingüística. Por lo tanto, la repetición de nuevas formas e inferencias en aspectos semánticos pueden dar lugar a la sistematización de cambios en el lenguaje y, como consecuencia, "la innovación se generaliza y queda codificada, es decir, deja de funcionar como una estrategia intencional" (Ridruejo, 2002, pág. 108), perdiendo, así, parte o la totalidad de su significado funcional (pragmático) original. En otras palabras, la intencionalidad pragmática en el uso de un recurso lingüístico puede suponer su gramaticalización o fijación en el lenguaje.

En consecuencia, los posibles cambios de significado derivados del uso del lenguaje con un propósito de inclusión y equidad desde una perspectiva sociolingüística, es decir, que impliquen procesos lingüísticos y extralingüísticos en su codificación y decodificación en una situación comunicativa, pueden fijar estos cambios semánticos generando innovaciones con un carácter funcional en la comunidad de hablantes. 


\subsection{Feminismo, activistas sociales}

Habiendo revisado las teorías que explican posibles cambios en el lenguaje y con el objetivo de entender la panorámica actual del feminismo en cuanto a las demandas en equidad de género y el énfasis en la modificación del uso de algunos recursos formales de la lengua para refrenar el denominado sexismo lingüístico (Cabeza-Pereiro \& Rodríguez-Barcia, 2013) o como respuesta al uso sexista del lenguaje (Vázquez-Hermosilla \& Santaemilia-Ruíz, 2011), consideramos necesario hacer un breve recorrido por la metáfora de las olas del feminismo. Solo de este modo se puede entender la lucha constante por la igualdad de género desde sus orígenes hasta la actualidad y, asimismo, reconocer la importancia del lenguaje como transmisor cultural de ideologías.

La primera ola del feminismo comprende desde mediados del siglo XVIII hasta mediados del XIX. El surgimiento del movimiento feminista liberal sufragista se enmarca dentro de tres acontecimientos históricos de suma relevancia, como la Revolución americana o de las trece colonias, la Revolución francesa y la Revolución industrial británica (Yepes et al., 2019). Es durante este contexto revolucionario en el que se ubica el inicio del activismo de las mujeres que se centrará fundamentalmente en el derecho al voto, educación, trabajo y propiedad (Gutiérrez, 2016). La expansión del ideario de la ilustración confluyó con el auge del liberalismo, el inicio del movimiento sufragista en Inglaterra y EE. UU., así como el movimiento para la abolición de la esclavitud.

La segunda ola, desde mediados del siglo XIX, está relacionada con los derechos políticos y se enmarca como la continuación de la primera. El panorama europeo ejemplificaba la prohibición no solo de la participación de mujeres en partidos políticos y su derecho al voto, sino también la ostentación de cargos públicos aún ocupados exclusivamente por hombres (Koven \& Mitchel, 2013). En Inglaterra no sería hasta 1918, año en que las mujeres por encima de 30 años pudieron ejercer su derecho a voto, o incluso más tarde en España, a partir de 1933, habiendo sido planteado inicialmente en 1931, durante el gobierno de la República, cuando este derecho fue otorgado. Por otra parte, el contexto de la Declaración de independencia de los EE. UU. aceleraría la reivindicación de los derechos de la mujer en 1848 con la declaración de Seneca Falls, ya que la igualdad de derechos pronunciada en la Declaración de independencia no abarcó al sexo femenino. La consecución del voto femenino en los EE. UU. se materializaría en 1920. Esta segunda ola también atestigua el surgimiento de diferentes perspectivas en el movimiento feminista, como el feminismo liberal, radical y socialista (Barret \& Phillips, 2003). Cada una de estas vertientes tiene diferentes elementos de análisis, así como distintos efectos ante la opresión del género femenino.

La tercera ola, enmarcada desde finales del siglo XIX hasta la actualidad, persigue la igualdad en derechos sociales y una completa integración, lo que conocemos como feminismos diversos, posmodernos e institucionales. El fin de un contexto de dictaduras y la segunda guerra mundial auguraban, a priori, un escenario no demasiado propicio para reivindicaciones de este tipo, ya que había países enteros por reconstruir. Sin embargo, el movimiento feminista se centró en demandar libertad sexual, igualdad económica (sa- 
larial), y políticas de democratización (Cornwall \& Goetz, 2005) que lograrían poner el foco de atención en el desequilibrio entre hombres y mujeres. Desde finales de 1980 hasta la actualidad, los roles de género, la discriminación salarial y condiciones laborales, sin olvidar la violencia de género como consecuencia más radicalizada, vuelven a estar sobre la mesa para ser abordados desde diferentes perspectivas y propiciar un contexto para lograr la igualdad y erradicar los problemas de género.

\subsection{Recursos para un uso no sexista del lenguaje}

Siguiendo las reivindicaciones de la tercera ola, que residen en el reconocimiento de la equidad entre sexos, nuestro debate se va a centrar, de una forma más específica, en los aspectos lingüísticos heredados y la problemática de género que subyace de los mismos en la actualidad. El contexto histórico y sociopolítico de España, al igual o de una forma muy parecida al resto de Europa, ha relegado a la mujer a un segundo plano tanto en derechos fundamentales como en cuanto a aspectos sociales y económicos, tal y como hemos descrito brevemente en la sección anterior. En la actualidad, aún podemos percibir el reflejo de una sociedad patriarcal que motivó el surgimiento del feminismo liberal ahora centrado, entre otras acciones, en el uso sexista del lenguaje y que demanda cambios para fomentar una realidad más inclusiva.

Centrándonos en los aspectos negativos derivados del uso sexista del lenguaje, encontramos la invisibilización del género femenino causada a nivel socioeconómico por un androcentrismo heredado que oculta o dificulta su visibilización (Martínez-Ramos, 2015). El mayor exponente es el uso del masculino genérico para designar a ambos sexos que, como consecuencia, oculta al género femenino. Del mismo modo, a nivel social, los roles y papeles del hombre y la mujer muestran estereotipos heredados del pasado que no describen a la sociedad actual. Por último, hay una falta de simetría en fórmulas de tratamiento que reside en el uso del sexo de las personas y, a menudo, conlleva un tratamiento discriminatorio o despectivo cuando se hace referencia al sexo femenino.

Vázquez-Hermosilla y Santaemilia-Ruiz (2011) recogen y describen las medidas adoptadas durante diferentes legislaturas a nivel estatal y provincial, en particular en la Comunitat Valenciana. Cabe destacar el seguimiento y desarrollo normativo de la Ley orgánica $3 / 2007$, de 22 de marzo para la igualdad efectiva de mujeres y hombres, mediante la cual el Instituto de la Mujer intenta materializar propuestas propias enmarcadas en los diferentes Planes Estratégicos de Igualdad de Oportunidades (PEIO). Dentro de estas propuestas, la última implementación corresponde al PEIO (2014-2016), ya que el siguiente (PEIO 2018-2021) está actualmente en proceso de elaboración. El último PEIO incluye 7 ejes principales:

- Igualdad en el ámbito laboral y lucha contra la discriminación salarial.

- Conciliación de la vida familiar, laboral y corresponsabilidad en responsabilidades familiares.

- Erradicación de la violencia contra la mujer. 
- Participación de las mujeres en ámbitos políticos, económicos y sociales.

- Educación.

- Políticas sectoriales más individualizadas.

- Instrumentos para integrar el principio de igualdad en las políticas y acciones del Gobierno.

Como complemento a este plan estatal, las comunidades autónomas pueden establecer planes autonómicos. Un ejemplo de ello es el Plan de Igualdad de Oportunidades (PIO) de la Generalitat Valenciana que, a su vez, puede venir reforzado por planes elaborados en municipios Pla Municipal per a la Igualtat d'Oportunitats entre Dones i Homes (PMIO), así como otros entes públicos como la Universitat de València.

Entre las medidas propuestas para fomentar la igualdad de género desde el punto de vista lingüístico, la elaboración de guías para el uso de lenguaje no sexista ha proliferado en diferentes instituciones como pueden ser universidades, gobiernos autonómicos y locales, y también por parte de sindicatos (Bosque, 2012). Esta reforma lingüística, también denominada Feminist Language Reform (Pauwels, 1998), tiene como objetivo la eliminación del lenguaje sexista mediante una aproximación sociolingüística, es decir, alcanzar una sociedad plural e igualitaria a través del lenguaje. La metodología de trabajo para la elaboración de estas guías comprende tres pasos fundamentales (VázquezHermosilla y Santaemilia-Ruiz, 2011). En primer lugar, la identificación, descripción y documentación de posibles rasgos sexistas en el lenguaje. Seguidamente, la propuesta de cambios en base a su factibilidad lingüística, teniendo en cuenta factores estilísticos, semánticos y pragmáticos del lenguaje. Por último, la puesta en marcha para la elaboración de una guía para el uso no sexista del lenguaje mediante la modificación, en la medida de lo posible, de los aspectos identificados como sexistas en el lenguaje. En cualquier caso, el producto final debe reflejar un paso adelante en los modelos cognitivos y de percepción del lenguaje inclusivo, ya que mediante el lenguaje y las relaciones de significado conceptualizamos nuestro pensamiento, confirmando una nueva realidad acorde a los tiempos de cambio y equidad que la sociedad demanda. Las guías elaboradas para un uso no sexista del lenguaje identifican los problemas principales y recomiendan las siguientes soluciones:

\subsubsection{El masculino genérico}

El uso del masculino genérico enmarca a mujeres y hombres. El uso extendido de términos masculinos para hacer referencia a los dos sexos puede generar ambigüedad en la interpretación de los mismos ya que, en según qué contextos, es difícil diferenciar si se hace referencia exclusiva al género masculino o a ambos. Entre las soluciones recomendadas para la distinción de género, se recomienda el uso de fórmulas desdobladas, su sustitución por sustantivos genéricos que engloben a ambos sexos, o la anteposición de artículos como modificadores restrictivos a los sustantivos genéricos, así como su concordancia total con adjetivos u otros sustantivos para lograr la distinción de sexo. Por el contrario, algunas guías recomiendan la omisión del determinante o artículo con 
sustantivos genéricos para evitar el sexismo lingüístico, siempre y cuando el contexto lo permita y no haya pérdida en el significado oracional. Como alternativa a la omisión del determinante, se aconseja el uso de formas invariables como cada, quien/es, cualquier en lugar de el/la, las/los, todos/as. Asimismo, también se recomienda la feminización de términos referentes a ocupaciones, como veremos más adelante en el uso de las fórmulas de tratamiento.

Las propuestas principales a nivel sintáctico proponen la adaptación del contenido lingüístico mediante el uso de la voz pasiva y pasiva refleja con verbos transitivos, así como la utilización de oraciones impersonales con verbos copulativos, intransitivos y transitivos precedidos de la preposición $a$ para referirse a personas (complemento directo de persona). También se aconseja el uso de perífrasis con verbos en participio cuando la concordancia del participio no oculte a un sexo u otro.

\subsubsection{Sustantivos genéricos}

Se recomienda el uso de sustantivos genéricos que impliquen colectividad o con matiz semántico abstracto para englobar a ambos sexos en lugar del masculino genérico. Ejemplos de sustantivos genéricos son persona/s, o humanidad. Por otra parte, los sustantivos colectivos son aquellos que no tienen matiz sexuado, como por ejemplo, personal, equipo, cuerpo, etc. También se recomienda el uso de sustantivos abstractos o construcciones metonímicas como dirección, presidencia o profesorado. Por último, se debe evitar el uso de falsos genéricos que designan a ambos sexos ocultando uno, por ejemplo hombre, ciudadano o trabajador.

\subsubsection{Fórmulas de tratamiento}

Como norma general, se recomienda no hacer referencia al estado civil como, por ejemplo, señora/viuda de, ya que supone la subordinación de un sexo en relación al otro. Nos referiremos, pues, a la persona concreta utilizando la fórmula masculina o femenina del pronombre y sustantivo según el sexo de la persona. Si el sustantivo es invariable, por ejemplo agente o especialista, se recomienda aplicar el artículo para marcar el género cuando sea necesario. Respecto al uso de fórmulas de tratamiento o cortesía en documentos abiertos, es aconsejable el uso de la barra así como el desdoblamiento de los adjetivos, por ejemplo, Estimados Sres. / Estimadas Sras. Por el contrario, se desaconseja el uso del artículo delante del apellido de las mujeres del mismo modo que no se hace con los hombres: bastaría con utilizar el nombre de pila. Otro aspecto que merece atención es la denominación de oficios y cargos ya que, según la orden 22 de marzo 1995 del Ministerio de Educación y Ciencia, se debe adecuar la denominación de los títulos oficiales y el oficio o cargo desempeñado al sexo de la persona para favorecer la inclusión. Consecuentemente, debemos designar los cargos y oficios desempeñados en relación al sexo de la persona que lo lleva a cabo mediante el uso de las normas de formación del femenino (-a, -ora, -enta) en los sustantivos que lo aceptan o el uso de terminaciones invariables (-ante, -ista, -ta, -tra) siempre que sea posible y manteniendo concordancia de género y número. Es recomendable evitar el uso de pares que implican inferioridad en 
la profesión que se designa o tienen un significado peyorativo hacia el género femenino, por ejemplo secretario/secretaria o sargento/sargenta ${ }^{4}$. También es coherente el uso de sustantivos colectivos cuando sea posible, alternar el orden entre masculino y femenino aleatoriamente o anteponer el género menos representado en el trabajo o cargo que se desempeña.

\subsubsection{Desdoblamiento}

El recurso del desdoblamiento ha sido uno de los procedimientos más comúnmente utilizado para la inclusión de ambos sexos en documentos abiertos, mediante el uso de determinantes, artículos, sustantivos y adjetivos desdoblados o utilizando el recurso gráfico de la barra. Sin embargo, la duplicidad en textos escritos y, sobre todo, orales, puede dificultar su lectura, además de generar problemas de concordancia. Es recomendable limitar el uso de este recurso a contextos en los que no se pueda aplicar cualquier otra alternativa lingüística que incluya a ambos sexos como son los sustantivos colectivos, genéricos y el uso de construcciones gramaticales impersonales.

El desdoblamiento implica incluir sustantivos o adjetivos en sus formas para masculino y femenino, separadas por "y", "o", "e". Para un uso apropiado y equitativo, resulta conveniente la anteposición del sexo menos representado en relación al sustantivo que se usa. Por consiguiente, ejemplos como mecánica o mecánico; limpiador o limpiadora serían inclusivos y adecuados a la norma. En los casos en que sea necesario duplicar artículo y sustantivo, se recomienda la duplicidad de una forma. Así pues, en lugar de escribir el competidor y la competidora, sería conveniente duplicar un único elemento, dando lugar a el y la competidora o el competidor y competidora. Este último ejemplo sigue la norma de determinar el sustantivo más cercano en lugar antepuesto. Para poder utilizar este recurso apropiadamente, se deben evitar duales aparentes que cambian de significado en base al género que hacen referencia al igual que las referencias a formas femeninas que implican relaciones de inferioridad, dependencia o con significado negativo.

En algunos casos, este recurso presenta dificultades de concordancia, ya que puede producir ambigüedad en la lectura según su contexto oracional. Las propuestas para el uso de los diferentes desdoblamientos recomiendan, en primer lugar y cuando sea posible, duplicar el artículo y no el sustantivo, utilizando la conjunción copulativa "y". En los casos en que aparezca artículo, sustantivo y adjetivo, las recomendaciones son las siguientes: en primer lugar, duplicar el sustantivo en ambos géneros, coordinándolo con la conjunción " $y$ " e intentar la sustitución del adjetivo por una oración y, en segundo lugar, buscar un adjetivo invariable como alternativa. La tercera alternativa supone duplicar los artículos y sustantivos pero no el adjetivo, que tomaría el género del sustantivo más cercano. En el caso de nombres de doble forma se recomienda el desdoblamiento de todos los componentes. En cuanto al orden de aparición en desdoblamientos, se propone anteponer el sexo femenino al masculino y no utilizar aposiciones explicativas referentes

4Véase Cabeza-Pereiro y Rodríguez-Barcia (2013) para un listado de pares vacíos femeninos en lo que respecta a las profesiones recogidos en el DRAE. 
al femenino después del uso de un masculino genérico, para evitar la subordinación de un género al otro.

\subsubsection{Símbolos}

El uso de recursos tales como la barra inclinada (/) con terminaciones en femenino y de manera más directa utilizando el símbolo de la arroba (@) y por último la grafía X para designar a ambos sexos (Martínez-Ramos, 2015) fue popularizado en los primeros intentos del uso no sexista del lenguaje. Sin embargo, estos presentan ciertos problemas. En el caso de la “@”, la problemática principal reside en el uso de un símbolo que carece de fonética y es, por lo tanto, impronunciable dentro de una palabra ya que, como símbolo, la “@” se designa mediante el término propio arroba. Cierto es que su uso se ha extendido a través del canal escrito en registros informales o más coloquiales. Sin embargo, cuando hablamos de su realización en el canal oral, entendemos que no se puede huir del desdoblamiento. Por ejemplo, la práctica de encabezar los correos con un “buenos días/tardes a tod@s" es decodificado por el lector por todos y todas. Podríamos decir que nuestro sistema cognitivo y de conceptualización semántica, aunque capaz de relacionar el símbolo con la dualidad de género, no puede escapar a la lectura del par o desdoblamiento.

En la misma línea, aunque menos extendido, el uso de la grafía " $X$ " obedece a un proceso parecido al del símbolo@. La diferencia reside en que la grafía sí es un signo lingüístico y su uso con este fin sería convencionalmente más normativo pero, aun así, difícilmente pronunciable: "IXs valencianXs, mis compañerXs". Por lo tanto, el desdoblamiento en su lectura es necesario ya que, al igual que pasa con la "@”, nuestro sistema lingüístico no tiene o aún no ha alcanzado la conceptualización de la dualidad de género representada por el uso de la grafía "X". Martínez-Ramos (2015) también describe el uso de los paréntesis o de la barra ascendente a modo de sufijación, añadiendo al sustantivo o adjetivo "(a)" o "/a" como determinación morfémica flexiva para visualizar género y número, por ejemplo señor(a/s) o estimado/a(s). El resultado del uso de estos recursos puede evitar el desdoblamiento a nivel escrito pero, por otro lado y, al igual que sucede con el símbolo "@” o la grafía "X”, carece de efectividad en el lenguaje oral, ya que sería necesario leer el desdoblamiento. También sería conveniente, en caso de su posible aplicación práctica, consensuar qué género toma el sustantivo o adjetivo principal y cuál es el género supeditado o referenciado mediante el morfema, por una cuestión de orden.

No obstante, se recomienda, en primer lugar, no utilizar símbolos en lenguaje administrativo ni común, ya que estos no han sido reconocidos lingüísticamente, además de ser impronunciables. Por el contrario, se propone el recurso de la barra inclinada para designar a ambos sexos en el diseño de formularios, en caso que no haya un sustantivo genérico o colectivo que reemplace las dos formas. En documentos abiertos, como pueden ser correos o cartas, se recomienda duplicar el sustantivo y adjetivo en caso de estar presente. Por ejemplo: Estimados alumnos / estimadas alumnas. 


\subsubsection{Duales aparentes}

Entendemos dual aparente como "las diferencias de significado entre algunas formas gramaticales femeninas y masculinas que tienen la misma base" (Couture-Grondin, 2011, pág. 51). Dentro de estos duales se pueden distinguir diferentes contextos, por ejemplo, en profesiones: sargenta y sargento; en expresiones con significado negativo según el sexo al que se refiera: tipo y tipa; y, por último, en vacíos léxicos por los que no existe el equivalente masculino o femenino: mujer/señora de la limpieza o ama de casa. Para fomentar el uso inclusivo del lenguaje, se recomienda hacer referencia a la forma masculina o femenina de cada cargo sin presuponer que el colectivo que desempeña un trabajo es mayoritariamente masculino o femenino. En el caso de palabras invariables, utilizar el artículo o paráfrasis para diferenciar el género gramatical cuando se requiera deshacer la ambigüedad.

\subsubsection{Saltos semánticos}

El salto semántico, definido como "el empleo de un sustantivo de forma masculina con valor genérico primero y luego con valor específico" (Díaz-Hormigo, 2007, pág. 38), puede producir la exclusión del sexo femenino en caso que no se haga referencia explícita en la frase a posteriori. Normalmente, la aparición de un sustantivo femenino después del uso de un masculino genérico se debe a la delimitación del alcance de este último. En consecuencia, tanto el hablante/emisor como el oyente/receptor pueden entender que, sin referencia al femenino, se nombra solo a varones. Como solución, se propone el uso de sustantivos genéricos, evitar también añadir el término femenino a posteriori como aposición, ya que puede establecer una relación de subordinación y, finalmente, el uso de otras alternativas a nivel sintáctico para evitar el salto semántico.

Después de haber hecho un breve resumen de los problemas principales y las soluciones que se plantean desde las guías de uso del lenguaje no sexista, solo cabe destacar la funcionalidad y aplicabilidad de algunos de estos principios en documentos oficiales abiertos, como pueden ser escritos institucionales o la elaboración de formularios en los ámbitos de diferentes administraciones públicas o privadas. Sin embargo, tal y como apuntan Vázquez-Hermosilla y Santaemilia-Ruiz (2011), al comparar algunas alternativas de mejora propuestas en las guías, encontramos ciertas contradicciones de unas con respecto a otras. En este sentido, sería conveniente homogeneizar los principios en este tipo de manuales para no caer en el error de utilizar recursos del lenguaje con una finalidad no sexista en función de la guía a que se hace referencia.

\subsection{Situación actual y perspectivas de futuro}

Partiendo de las demandas iniciadas por los colectivos feministas que en la actualidad reclaman una mayor visibilización de la mujer en el lenguaje mediante el uso no sexista del mismo y las consideraciones previamente mencionadas, se pueden extraer las siguientes conclusiones. Es cierto que el castellano es una lengua con género gramatical y su adecuación para un uso equitativo y no sexista es una tarea más ardua que en otras 
lenguas como el inglés, en el que se ha optado por la neutralización de género a nivel léxico. En castellano, la alternativa propuesta a nivel morfológico en la mayoría de las guías es la dualización de género mediante recursos como el desdoblamiento o el uso de sustantivos genéricos, abstractos o colectivos carentes de género que, como hemos visto, no soluciona del todo la problemática al anteponer artículos o posponer adjetivos tanto en cuestiones de género como de orden. Por otro lado, el uso de recursos gramaticales, como la voz pasiva, la pasiva refleja y otras construcciones impersonales como las perífrasis verbales para fomentar la equidad, han sido recomendados con el fin de eludir recursos ampliamente empleados, como el masculino genérico, para hablar de un grupo mixto. Podemos decir, entonces, que las guías para el uso no sexista del lenguaje funcionan como una herramienta de consulta para la adecuación del lenguaje con la finalidad de equiparar ambos sexos en el marco lingüístico. A pesar de su funcionalidad y aplicabilidad en documentos institucionales, Vázquez-Hermosilla y Santaemilia-Ruíz (2011) apuntan hacia un cambio de perspectiva en la reforma lingüística como solución al sexismo lingüístico en castellano.

Dicha reforma debe considerar, en primer lugar, la necesidad expresiva de los hablantes en el contexto actual, tal y como apuntaba Coseriu (1973), la innovación, creatividad y libertad en los usos del lenguaje son la clave que refleja el dinamismo del lenguaje y su adaptabilidad. En segundo lugar, el cambio o "la variación lingüística tiene carácter gradual" (Briz, 2010, pág. 125), es decir, dentro del dinamismo del lenguaje, los procesos de sedimentación y fosilización de nuevos términos o el uso de fórmulas gramaticales específicas requieren tiempo tanto para llegar a diferentes estratos sociales como para su pragmatización o gramaticalización (Ridruejo, 2002). La lengua crea y describe la realidad mediante procesos de adaptación a posibles cambios sociales que, por desgracia, no son tan rápidos como la fijación de anglicismos relacionados con los ámbitos de la tecnología y moda. Así pues, los cambios relevantes necesitan más tiempo. Por último pero no menos importante, es necesario prestar atención a aspectos sociales, culturales e ideológicos que han tenido y siguen teniendo una gran influencia en el sexismo lingüístico (Cabeza-Pereiro y Rodríguez-Barcia, 2013) ya que tan difícil puede ser la creación de relaciones de significado nuevas como desarraigar las heredadas para compensar el androcentrismo. En consecuencia, se recomienda tener en cuenta la parte ideológica del lenguaje en cuanto al uso del humor, estereotipos y mensajes conflictivos, lo que Mills (2008) describe como sexismo indirecto. En línea con Vázquez-Hermosilla y Santaemilia-Ruíz (2011), consideramos que también es importante centralizar esfuerzos en generar una herramienta para los hablantes que explique el porqué del sexismo en ciertos usos del lenguaje mediante un análisis pragmático de situaciones comunicativas cotidianas con el objetivo de contribuir y concienciar a comunidades de hablantes a nivel local para una posterior implementación a nivel institucional. 


\subsection{Referencias bibliográficas}

Alonso, A. (1967). Noción, emoción, acción y fantasía en los diminutivos. Estudios lingüísticos. Temas españoles, Madrid, Gredos, 161-189.

Barrett, M., \& Phillips, A. (2002). Desestabilizar la teoría. Paidós.

Blas-Arroyo, J. L. (2003). Perspectivas (socio) lingüísticas complementarias en el estudio de la variación y el cambio lingüístico en español. Estudios de Sociolingüística, 4 (2), 653-692.

Blas-Arroyo, J. L. (2005). Sociolingüística del español: desarrollos y perspectivas en el estudio de la lengua española en contexto social. Ediciones Cátedra.

Bosque, I. (2012). Sexismo lingüístico y visibilidad de la mujer. Madrid, España: Real Academia Española.

Briz, A. (2010): Lo coloquial y lo formal, el eje de la variedad lingüística, en Castañer Martín, Rosa María y Vicente Lagüéns Gracia, coords., De moneda nunca usada: Estudios dedicados a José M. ${ }^{a}$ Enguita Utrilla, Zaragoza, Instituto Fernando El Católico, CSIC, 125-133.

Cabeza-Pereiro, M. D. C., \& Rodríguez-Barcia, S. (2013). Aspectos ideológicos, gramaticales y léxicos del sexismo lingüístico. Estudios filológicos, (52), 7-27.

Cornwall, A., \& Goetz, A. M. (2005). Democratizing democracy: Feminist perspectives. Democratisation, 12(5), 783-800.

Coseriu, E. (1973). Sincronía, diacronía e historia (Vol. 193). Madrid: Gredos.

Coupland, N. (2001). Sociolinguistic theory and social theory. In N. Coupland, S. Sarangi y C.N. Candin (eds.), Sociolinguistics and Social Theory. London, Longman: 1-26.

Couture-Grondin, É. (2011). Hacia un lenguaje más igualitario: El aporte de la literatura femenina. Tinkuy: Boletín de investigación y debate, (15), 49-63.

Díaz-Hormigo, M. T. (2007). Comentarios lingüísticos a la Guía para un uso igualitario del lenguaje administrativo. Revista de investigación lingüística 10, 7-40.

Escrig-Gil, G. y Sales-Boix, A. (2010). Guía de tratamiento no sexista de la información y la comunicación en la Universitat Jaume I. Unidad de Igualdad de la Universitat Jaume I.

Gil, G. E., Boix, A. S., \& Porcar, M. J. O. (2016). Guía de tratamiento no sexista del lenguaje administrativo. Fundación Isonomia, Universitat Jaume I.

Gutierrez, J. C. (2016). Mothering and Nationalism in Egypt (Doctoral dissertation, American University of Beirut).

Hodge, C. T. (1970). The linguistic cycle. Language sciences, 13(7), 1-7.

Jefatura de Estado (2007). Ley Orgánica 3/2007, de 22 de marzo, para la igualdad efectiva de mujeres y hombres (BOE $\left.\mathrm{n}^{\mathrm{o}} 71\right)$. 
Koven, S. \& Mitchel, S. (1990). Womanly Duties: Maternalist Politics and the origins of Welfare States in France, Germany, Great Britain, and the United States, 18801920. The American Historical Review, 95(4), 1076-1108.

Labov, W. (1972). Language in the Inner City: Studies in the Black English Vernacular. University of Pennsylvania Press, Philadelphia, PA.

Lass, R. (1997). Historical linguistics and language change (Vol. 81). Cambridge University Press.

Lightfoot, D. (1999). The development of language: Acquisition, change, and evolution. Wiley-Blackwell.

Marimón-Llorca, C., \& Santamaría-Pérez, I. (2011). Guía para un discurso igualitario en la Universidad de Alicante. Alicante: Universidad de Alicante, Vicerrectorado de Relaciones Institucionales, Unidad de Igualdad, Centro de Estudios sobre la Mujer.

Martínez-Ramos, M. (2015). Lenguaje de género:¿ necesidad o necedad? Entretextos, 7(20), 1-9.

Mendivil-Giró, J. L. (2010). Coseriu, Saussure y el problema del cambio lingüístico. Boletín de la Sociedad Española de Historiografia Lingüística, (7), 109-128.

Mills, S. (2008). Language and sexism. Cambridge: Cambridge University Press.

Noverón, J. R. (2005). Procesos de gramaticalización por subjetivización: el uso del diminutivo en español. In 7th Hispanic Linguistics Symposium. Cascadilla Proceedings Project (pp. 79-86).

Pauwels, A. (1998). Women Changing Language. London: Longman.

Quilis-Merín, M., Albelda-Marco, M. y Josep-Cuenca, M. (2012). Guía de uso para un lenguaje igualitario (castellano). Tecnolingüística: Universitat de València.

Ridruejo-Alonso, E. (2002). Cambio pragmático y cambio gramatical. Language design: journal of theoretical and experimental linguistics, 4, 095-111.

Saussure, F. D. (1916). Cours de linguistique générale, Paris: Payot (cit. por la edición de T. de Mauro y traducción de A. Alonso. Curso de lingüistica general. Madrid: Alianza, 1983)

Vázquez-Hermosilla, S., \& Santaemilia-Ruiz, J. (2011). Las guías de uso no sexista del lenguaje: la situación de la lucha por la igualdad entre mujeres y hombres en la Universitat de València. Ianua. Revista Philologica Romanica, (11), 171-186.

VV. AA. (2014): Plan Estratégico de Igualdad de Oportunidades (PEIO) 2014-2016. Madrid: Ministerio de Sanidad, Servicios Sociales e Igualdad.

Yepes, T. G., Bría, M. P., Etchezahar, E., \& Ungaretti, J. (2019). Feminismos y Activismo de Mujeres: Síntesis Histórica y Definiciones Conceptuales. Calidad de Vida y Salud, 12(1). 


\title{
Capítulo 3 \\ La voz de la sirena de Carme Riera. Una lectura hipertextual
}

\author{
Elizabet Contreras Barceló \\ Dpto. de Educación Lingüistica y Literaria, y \\ Didáctica de las Ciencias Experimentales y la Matemática \\ Universitat de Barcelona
}

\subsection{La hipertextualidad literaria y el lector en formación}

En las últimas décadas, los planteamientos sobre el carácter universal de la hipertextualidad y la intertextualidad literaria, planteadas en su día por Gerard Genette (1989), han enriquecido notablemente los estudios literarios. Genette, en su obra Palimpsestos. La literatura en segundo grado (1989), conceptualiza las relaciones que se establecen entre distintos textos y sus significaciones, a partir del término intertextualidad. Este concepto implica la utilización de elementos discursivos, temáticos, simbólicos, argumentales, etc. de un texto determinado en una reescritura o reelaboración parcial o total posterior. Otros autores como Umberto Eco (2002) han puesto de manifiesto que la recurrencia y la ironía hipertextual se han convertido en una característica de la narrativa posmoderna.

El hecho intertextual debe analizarse teniendo en cuenta tanto la producción como la recepción. En cuanto al proceso creativo, se considera como un procedimiento basado en el uso de formas y modalidades procedentes de otras obras literarias $-\mathrm{u}$ otros productos culturales- que se seleccionan, combinan y recrean con un objetivo intencionado concreto, dando paso así a una reescritura o recreación. Según la relación con la obra original (hipotexto), Genette (1989) establece una clasificación en la que distingue entre transformación e imitación; y según sea su intención se puede hablar de régimen lúdico, satírico o serio. Teniendo en cuenta el tipo de relación con el hipotexto y su régimen, Genette considera seis tipos de prácticas hipertextuales: parodia (transformación lúdica), travestimiento (transformación satírica), transposición (transformación seria), pastiche (imitación lúdica), imitación satírica e imitación seria.

El texto resultante exige la cooperación del lector para una comprensión plena. Este debe interactuar con el texto, ser capaz de establecer relaciones entre el hipotexto y la reescri- 
tura, configurando así una red de relaciones intertextuales. Por esta razón, se considera que la presencia de estos elementos intertextuales se halla en los textos, pero también en los lectores, pues durante el proceso de lectura, el receptor debe buscar en su experiencia literaria acumulada modelos y patrones que le recuerden el texto. En este acto de lectura, el lector debe (o debería) ser capaz de establecer interrelaciones entre el hipertexto y el correspondiente hipotexto, gracias a su intertexto lector (Mendoza, 2001). Según Genette, el hecho intertextual es inevitable, incluso en el caso de que el lector no pueda apreciar la conexión entre los diferentes textos, ya sea por falta de bagaje literario o por falta de estrategias para relacionar distintas obras.

En este sentido Umberto Eco destaca que en la mayoría de casos de intertextualidad, el texto puede ser leído de manera ingenua, sin captar recurrencias hipertextuales, o con plena consciencia de los referentes que aparecen de forma más o menos explícita. Con lo cual, el autor sentencia "tendríamos que decir quizá que, en virtud de esta estrategia citacionista, un texto presenta dos niveles de lectura” (Eco, 2002, pág. 231)

El hecho intertextual es innegable y su clave la tienen los lectores, porque en sus manos está la identificación de todos aquellos elementos de referencia que guían y pautan el proceso de lectura y hacen posible las conexiones temáticas, argumentales y discursivas entre el hipertexto y el hipotexto. Para que tal asociación sea viable, debe haber experiencias de lectura previas que faciliten la correcta activación del proceso de recepción (formulación de expectativas, previsión del desarrollo de la acción, proyección de cada nueva situación...), profundizar en diferentes modalidades discursivas, descubrir las relaciones entre hipertexto e hipotexto, tanto por lo que se refiere a aspectos temáticos y argumentales como a las macroestructuras y microestructuras de las obras.

Desde la teoría de la recepción, el profesor Mendoza (2002) destaca la importancia de los efectos que comporta la lectura reiterada de determinados modelos y otros elementos literarios en el lector, sobre todo, en su fase formativa. Cada experiencia literaria contribuye progresivamente a incrementar referentes que amplían el intertexto discursivo y el intertexto de los lectores y mejoran su competencia literaria básica, lo cual les proporcionará un bagaje literario suficiente para poder afrontar en el futuro cualquier tipo de lectura y ser capaces de identificar elementos del imaginario colectivo y de las obras literarias canónicas de su tradición cultural.

Precisamente, en el campo de la literatura infantil, donde personajes, situaciones y modelos discursivos se reiteran, la intertextualidad es un hecho histórico que afecta todas las producciones culturales, no solo literarias. En la literatura para niños y jóvenes se han perpetuado esquemas narrativos en los cuentos y en las distintas funciones y roles de los personajes arquetípicos, que se han ido formulando y reformulando a lo largo de los siglos.

El conte és un discurs hipertextual, on conflueixen els condicionants de la ficció, els recursos literaris del llenguatge, els recursos que confereixen el caràcter lúdic de la producció 
literària $\mathrm{i}$ els esquemes narratius de base, juntament amb les marques indicadores de la intencionalitat estètica o les claus de la interpretación ${ }^{5}$ (Mendoza, 2002, pág.155).

Así, el conjunto de referencias intertextuales contribuye a mejorar las habilidades receptoras y facilitan la capacidad de relacionar saberes, conocimientos y experiencias culturales anteriores. Por este motivo:

Els aspectes intertextuals de les narracions infantils i juvenils mostren clarament la seva
funció per canalitzar la capacitat receptora del lector en formació i de la seva capacitat cog-
nitiva per combinar sabers i estratègies amb components discursius i d'orientació estètica
que, en el seu conjunt, li permeten d'actuar amb autonomia en el procés de recepció i en al
construcció de significats i interpretacions ${ }^{6}$ (Mendoza, 2002, pág.157)

A medida que el lector en formación está más en contacto con obras literarias y con productos culturales en general, se va ampliando su base literaria, su bagaje y su capacidad de conectar distintas obras a partir de la identificación de elementos. De este modo, se va ampliando su competencia literaria y se incrementa su intertexto lector, que Mendoza (2002) define como el conjunto de saberes y las experiencias receptoras del lector que le permiten leer, gradualmente, obras de mayor complejidad literaria. Cuando un lector de este tipo se halla ante un hipertexto, pone en funcionamiento el mecanismo de recepción que activa las claves de una correcta interpretación del texto. A través de los referentes y los elementos discursivos que va reconociendo y que le guían a lo largo del texto, puede llevar a cabo el proceso de recepción con éxito. Gracias a las lecturas previas que configuran el bagaje literario, el lector es capaz de entender los indicadores y sus intenciones, haciendo asociaciones intertextuales, a partir de elementos e indicadores que evocan la obra original en la nueva reescritura, lo cual permite la atribución de un significado correcto y una interpretación adecuada al hipertexto (Mendoza 2002).

\subsection{La sirena, un personaje hipertextual}

Dentro de esta dinámica hipertextual de la literatura, se halla el personaje de la sirena, protagonista de numerosas manifestaciones culturales a lo largo de la historia de occidente. Esta mujer con cola de pez que vive en las profundidades del mar tiene origen grecolatino, sobrevivió siglos a través de leyendas marinas y llegó a la literatura infantil de la mano de H. C. Andersen. Un siglo y medio más tarde, la factoría de Walt Disney hizo una reescritura hipertextual del cuento, a través de una película de animación, y su protagonista -la Sirenita- pronto se convirtió en una de las princesitas Disney más po-

5Traducción al castellano: "El cuento es un discurso hipertextual, donde confluyen los condicionantes de la ficción, los recursos literarios del lenguaje, los recursos que confieren el carácter lúdico de la producción literaria y los esquemas narrativos de base, junto con las marcas indicadoras de la intencionalidad estética o las claves de la interpretación".

6Traducción al castellano: "Los aspectos intertextuales de las narraciones infantiles y juveniles muestran claramente su función para canalizar la capacidad receptora del lector en formación y de su capacidad cognitiva para combinar saberes y estrategias con componentes discursivos y de orientación estética que, en su conjunto, le permiten actuar con autonomía en el proceso de recepción y en la construcción de significantes e interpretaciones". 
pularizadas. Años más tarde, Carme Riera retoma la obra de Andersen y la de Disney y elabora una reescritura de La Sirenita en clave feminista. De modo que se podría afirmar que la sirena es un personajes propio del imaginario colectivo de la literatura gracias en parte a su carácter hipertextual.

\subsubsection{Los orígenes clásicos de la sirena}

La sirena es un ser mitológico que aparece documentado por primera vez en el viaje de Ulises, escrito por Homero en el siglo VII a. C. Las sirenas aparecen como jóvenes encantadoras que atraían a los marineros con sus dulces voces. Según algunas versiones del mito (March 2002; Grant \& Hazel 1997), las sirenas eran hijas del dios fluvial Aqueloo y de una de las musas y vivían en la isla de Antemoesa. Siglos más tarde, Ovidio publicó, en el año 8 d. C., Las metamorfosis, donde cuenta cómo las sirenas estaban con Perséfone cuando esta fue secuestrada por Ares. Fue entonces cuando Deméter, la madre de Perséfone, las convirtió en mujeres-pájaro como castigo por haber permitido que Ares se llevara a su hija. Desde entonces, las sirenas aladas, desde su isla, atraían con su dulce voz a los marineros y los hechizaban para que se tiraran al agua. Si algún navegante era capaz de resistirse a la tentación, en tal caso, eran ellas las que se tiraban al agua y, claro está, con un cuerpo de pájaro morían ahogadas. Más tarde, Afrodita, diosa del amor, se compadeció de las pobres sirenas y las dotó de una cola de pez para que pudieran sobrevivir en el agua, si un marinero se resistía a sus encantos.

Desde entonces, este personaje sobrevivió en el imaginario colectivo de la sociedad occidental hasta H. C. Andersen, que lo utilizó como protagonista en un cuento infantil.

\subsubsection{La sirenita de Andersen, un personaje romántico}

Según la autora Bettina Hürlimann (1982), Hans Christian Andersen (1805-1875) fue un gran revolucionario de la literatura infantil. Sus cuentos se basaban en episodios autobiográficos o en cuentos populares y supusieron un revulsivo en la narrativa para niños gracias a su estilo oral, el ingenio, la ironía, la poesía y el frescor, que impregnan sus páginas y lo convirtieron en un cuentista de referencia. Su maestría y sensibilidad conmovieron a lectores de todas las edades con finales tristes. Las obras de Andersen, entre las que se halla, La sirenita, no puede leerse desvinculada del movimiento cultural que desde hacía unas décadas se respiraba en Europa. En su obra se encuentran elementos románticos que se repiten en otros autores y obras no necesariamente infantiles de la época. Por ejemplo, la recurrencia a los mitos y leyendas para contar historias, los protagonistas que intentan encontrar la felicidad a pesar del dolor que comporta y de su incapacidad de conectar con una sociedad que no los comprende, o el fuerte vínculo que estos sienten con elementos naturales como la noche o la Luna, son algunos aspectos presentes en la llamada literatura romántica y también en la narrativa de Andersen. 
A pesar de la complejidad que supone definir una corriente artística y cultural tan vasta, René Wellek (1983) sentenció que:

\begin{abstract}
Si examinamos las características de la literatura existente que a sí misma se llamó o fue llamada "romántica" en todo el Continente, encontramos a todo lo largo de Europa las mismas concepciones de la poesía y de las obras y de la naturaleza de la imaginación poética, la misma concepción de la naturaleza y de su relación con el hombre, y, básicamente, el mismo estilo poético, con un uso de la metáfora, del simbolismo y del mito evidentemente distinto empleado por el neoclasicismo del siglo XVIII. [...] el arte como la búsqueda a tientas del ideal. Todos los tipos de exotismos forman parte de la reacción en contra del siglo XVIII y de su autocomplacencia; las reprimidas fuerzas del alma buscan sus analogías y modelos en la prehistoria, en el Oriente, en la Edad Media y, finalmente, en la India así como en el inconsciente y en los sueños (1983, págs.147-151).
\end{abstract}

A partir de la presente definición parece más que oportuno leer La sirenita a la luz del Romanticismo, incluso atender a su protagonista como una heroína de rasgos goethianos, por su carácter tristón y pensativo, la incapacidad de adaptarse a su sociedad, la voluntad de lo inefable e imposible, la búsqueda del amor ideal, el sufrimiento para alcanzar la felicidad, el valor para arriesgarlo todo y el final trágico.

De este modo, el personaje de la sirena representa claramente un ejemplo de hipertextualidad. Se trata de un personaje que lleva a cuestas una mochila llena de connotaciones mitológicas, de leyendas y de Romanticismo. Su caracterización se ha ido complementando, fruto de las relaciones intertextuales que se establecen entre las distintas obras en las que aparece. De modo que cuando Walt Disney reescribe el cuento de Andersen, el espectador activa su reconocimiento del hipotexto, del mismo modo que cuando Carme Riera presenta una reescritura de la historia del autor danés, el lector automáticamente reconoce la obra de Disney y la del danés como hipotextos a partir de los cuales construye el significado de la nueva obra.

En conclusión, la mujer con cola de pez está presente en muchas y diversas manifestaciones culturales y literarias. A lo largo de la historia se ha convertido en un personaje importante dentro del imaginario colectivo, muy sugestivo y con fuerza estética, lo cual ha dado pie a muchas reescrituras entre las que se halla La voz de la sirena de Carme Riera.

\title{
3.3. La voz de la sirena: una reescritura
}

Siguiendo la terminología de Gerard Genette (1989) y su concepto de intertextualidad literaria, expuesto anteriormente, se puede afirmar que la obra objeto del presente estudio, La voz de la sirena (Riera, 2015) es una obra hipertextual de transposición literaria, es decir, que se trata de una parodia seria del hipotexto La sirenita de Andersen y, en menor medida, de La Sirenita de Walt Disney. Esta relación hipertextual se hace evidente y explícita porque en el interior del libro se encuentra el mismo cuento de Andersen, en un formato más pequeño, en páginas de color azul. El cuento de Andersen en el interior y en hojas azules no es el único detalle preciosista de esta cuidada edición, pues toda la obra ha sido ilustrada con gran sensibilidad por Helena Pérez, que alterna los colores 
rojo y azul para dar más fuerza simbólica al texto: el rojo del dolor y la sangre y el azul de la nostalgia y el mar.

Carme Riera pone de manifiesto en la primera página que se trata de un hipertexto de La sirenita de Andersen, pero también de la popularizada versión cinematográfica que hizo Walt Disney. "Después de Andersen, que no siempre acierta la verdad, Walt Disney endulzó el relato y lo aprovechó para llevarlo al cine, divulgándolo todavía más.'] (Riera, 2015, pág. 9). A partir de dicha afirmación, tanto La sirenita de Andersen como la de Walt Disney deben ser consideradas hipotextos, pues a ambas se hace referencia en distintas ocasiones a lo largo del texto. Se trata pues, de una opción muy coherente si se tiene en consideración al lector potencial de La voz de la sirena-que coincide con el perfil que se describe en la experiencia didáctica aplicada al aula de educación en LIJ (Prats i Ripoll \& Contreras i Barceló, 2019)-: una chica joven que, seguramente, creció viendo las películas de la factoría Disney, protagonizadas por bellas princesas que buscaban su príncipe azul, entre las que ocupó un lugar prominente, Ariel, la sirenita.

Volviendo al análisis del hipotexto, es cierto que el cuento popular o popularizado no se puede considerar, por definición, un hipotexto fijo, porque se transmite oralmente de generación en generación y esta condición implica que se vayan mezclando, reinterpretando y añadiendo motivos, acomodándose a nuevas realidades sociales y a las necesidades de los nuevos oyentes. A pesar de ello, a lo largo del siglo XX se pueden encontrar muchos productos culturales (no solo literarios) que son reescrituras de las versiones más conocidas de los cuentos populares o popularizados, que se dirigen a receptores infantiles o adultos que conozcan bien el hipotexto y puedan detectar elementos intertextuales, establecer paralelismos y hacer una lectura atenta en segundo grado (Genette, 1989). La mayoría de estos hipertextos se elaboran a la luz de movimientos heterodoxos -como será el feminismo en el caso que nos ocupa- a demanda de una sociedad que necesita nuevos modelos, con lo cual se entiende que estas reescrituras para un público infantil pueden ser muy ideológicas, incluso cuando pretenden ser una lectura lúdica (Díaz-Plaja, 2002).

Los procedimientos de reescritura de estos hipertextos pueden ser diversos. A partir de la clasificación de Genette y de ejemplos de reelaboraciones en literatura infantil y juvenil, Díaz-Plaja (2002) establece una clasificación propia para este tipo de literatura, en la que destacan cuatro tipos de procedimientos hipertextuales: las reescrituras simples, que son versiones que respetan la trama original, pero con algunos cambios que no la alteran de manera significativa, aunque sí que pretenden dar unas circunstancias más actuales a la obra; las expansiones, cuyo objetivo es partir de un relato y ampliar sus posibilidades temáticas y argumentales, con lo cual el lector asiste a qué sucedió antes, durante o después de la acción conocida; las modificaciones, en las que el cuento ha sufrido una reinterpretación para dar otro sentido a la obra, a partir de cambiar la trama o el rol de los personajes, de modo que el lector identificará los elementos gracias al contraste; y finalmente, presenta los collages, que mezclan elementos de varios cuentos y puede llevarse a cabo de maneras distintas: mezclando elementos, personajes, insertando un 
cuento dentro de otro, etc. A partir de esta clasificación de los tipos de hipertextos que se hallan en la literatura infantil y juvenil, se puede afirmar que La voz de la sirena supone una reescritura simple que "respeta la trama original, pero con alguna modificación que no pretende alterar el sentido genuino del cuento. Sí que pretende, sin embargo, acercarlo al lector contemporáneo" (Díaz-Plaja, 2002, pág. 166).

Asimismo, es también una expansión del cuento porque “el objetivo es partir de un relato y expandir sus posibilidades temáticas" (Díaz-Plaja, 2002, pág. 166), pues se narran partes, como por ejemplo la vida de la sirena antes de ver al príncipe, que no aparecen en el hipotexto con la intención de enriquecer la figura principal de la sirena.

Riera respeta la trama narrativa original de Andersen, que también se encuentra en la versión de Disney: una joven sirena se enamora de un humano y sacrifica su cola de pez y su voz para convertirse en una mujer, perdiendo así su condición y esencia de sirena. Sin embargo, incorpora un cambio de narrador que permite modificar la perspectiva del relato, expandiendo el texto en la profundidad psicológica de la protagonista y, a la vez, modificándolo en su esencia, de modo que deja de ser un cuento de hadas para convertirse en una novela juvenil con un claro mensaje feminista.

Por lo tanto, Riera mantiene el sentido genuino del hipotexto, fácilmente identificable por el lector contemporáneo, e incorpora un conjunto de elementos hipertextuales que contribuyen a una reescritura en clave feminista, basada en la configuración de un nuevo modelo de princesa de cuento de hadas.

\subsection{Elementos clave del hipertexto}

Con La voz de la sirena, Riera pretende hacer una reescritura de La sirenita de Andersen, con un claro mensaje feminista, a través de la desmitificación de una de las más grandes historias de amor romántico, un referente de la literatura infantil no solo por la obra del autor danés, sino también por la popularizada versión cinematográfica que hizo la factoría Disney en los 90, referente cultural de varias generaciones. Para conseguir este objetivo, Riera utiliza un cambio de narrador: desestima el narrador externo de Andersen y de Disney y utiliza un narrador protagonista, en primera persona. De este modo, la voz de la sirena se convierte en un elemento fundamental porque empodera a la protagonista, le permite decir y decidir. De este modo, la voz aparece como un elemento clave y metafórico que permite reinterpretar la versión romántica y la cinematográfica. Y esta reinterpretación empieza por el título mismo: ya no se trata de una "sirenita" sino de "la voz de la sirena". Véase el inicio del hipertexto:

Aseguran quienes cuentan mi historia, que desde hace mucho tiempo transmiten las olas del mar, que el amor me enturbió los sentidos. El amor y el deseo de un alma inmortal, añade Andersen en un cuento muy difundido durante la época en que cada hombre esperaba encontrar su sirena, con la ilusión que el encuentro no conllevara ningún peligro y por esto a menudo nos preferían sin voz (Riera, 2015, pág.9) 
La aparición de esta "voz" implica el cambio de narrador y de perspectiva, que es la aportación más sustancial de la reescritura, porque permite llevar a cabo el principal objetivo del hipertexto: reescribir La sirenita en clave feminista. A partir de aquí, todos los elementos que intervienen en la obra contribuyen a reforzar una idea: el amor ideal de los cuentos de hadas no existe - al menos no literalmente- $y$, a menudo, ha comportado la perdición de la mujer para desarrollar una vida personal y profesional plena (Olid, 2011).

Pero me equivoqué. Me lo jugué todo a una carta única y cifrada del amor, como tantas mujeres han hecho a lo largo de la historia inacabable de amores desgraciados y terribles (Riera, 2015, pág.10)

Gracias a esta "voz", Riera crea una protagonista que cuenta en primera persona la verdadera historia de la sirenita, una historia de amor como tantas otras, en la que ella lo sacrifica todo por el amor de un príncipe que no lo merecía. Además, con la introducción de un narrador protagonista, la autora dota al relato de mayor verosimilitud y contribuye a crear complicidades entre la protagonista y el lector o lectora, adolescente o postadolescente, que creció entre historias de amor ideales y que moldea su futuro en función de aquello que su amor espera de ella.

Para terminar con el mito de este tipo de amor y la visión dulzona de las princesas, Riera crea un personaje joven, deportista, rebelde e inconformista. Aquella sirenita frágil e inocente, se convierte en el hipertexto en un personaje contemporáneo de 13 años: estudia, practica deporte de élite, se siente incomprendida, no tiene muy buena relación con su familia... En definitiva, se transforma en una adolescente con un comportamiento típico de su edad.

Con este personaje, Riera erradica la visión simplista de los personajes femeninos a lo largo de la historia de la literatura, en que las mujeres han aparecido desarrollando un rol determinado en función de su relación con el hombre: madre, hija, hermana, esposa, amante. Con esta nueva caracterización, el personaje no se presenta ante el lector como una visión parcial y masculina de la protagonista de un mito que es mirada con condescendencia y ternura, como hizo, por ejemplo, Walt Disney, sino como un individuo complejo e independiente. De ahí que tenga nombre propio -Clionda- y no sea la sirenita sino la sirena. Y es que con esta novela, Riera quiere poner fin también a la visión puramente sexista de los personajes femeninos, que tan bien analizó Virginia Woolf en Una habitación propia en 1928:

Era extraño que, hasta Jane Austen, todos los personajes femeninos importantes de la literatura no solo hubieran sido vistos exclusivamente por el otro sexo, sino desde el punto de su relación con el otro sexo. Y esta es una parte tan pequeña de la vida de una mujer... (...) De ahí, quizá, la naturaleza peculiar de la mujer en la literatura; los sorprendentes extremos de su belleza y de su horror; su alternar entre una bondad celestial y una depravación infernal. Porque así es cómo la veía un enamorado, según su amor crecía o menguaba, según era un amor feliz o desgraciado (Woolf, 1992, págs. 113-114)

De este modo, el personaje de la sirena se convierte en una pieza clave del engranaje hipertextual. Aquella sirenita romántica, heroína de reminiscencias goethianas, condenada 
a amar a alguien fuera de su alcance, o la posterior sirenita inocente, frágil y feliz de Disney, en la obra de Riera, se convierte en la narradora de su propia historia para conseguir desmitificar las historias de amor de finales felices y liberar a las chicas de la obligación de ser princesas (Olid, 2011). Esta modificación que actúa como base del hipertexto afecta a la misma esencia del personaje y permite incorporar una serie de cambios que tienen como objetivo la reescritura en clave feminista.

Uno de estos cambios afecta directamente a la estructura de la obra. Andersen, como buen romántico, dedica una parte sustancial del cuento al proceso de enamoramiento y al sufrimiento de la sirenita durante este tiempo. En el cuento del autor danés, desde que ve al príncipe por primera vez, hasta que decide ir en su búsqueda pasan meses. En cambio, en el hipertexto, entre que la sirena ve al príncipe por primera vez y decide escaparse de casa apenas pasan unos días. Este hecho tiene consecuencias en la estructura narrativa de la obra; la autora despacha en relativamente pocas páginas la fase del enamoramiento, para dedicar la parte más importante del libro a la fase de la convivencia entre la sirena y el príncipe. Evidentemente, esta modificación no es gratuita, obedece a la voluntad de matizar la caracterización de los dos personajes y el tipo de relación que les une; además de hacer hincapié en el hecho de que en la realidad, a diferencia de los cuentos de hadas, después de conseguir estar juntos, llega el día a día, y la convivencia entre los amantes a menudo es difícil.

La sirena de Riera solo tiene 13 años, es deportista de élite y está acostumbrada al esfuerzo y al sacrificio, no como la de Andersen que solamente se dedicaba a peinarse y a cuidar de su jardín. A pesar de que la sirena es una gran deportista, con grandes habilidades en salto olímpico, quiere abandonar su carrera para conseguir la deseada libertad. En un acto de rebelión, se salta un entrenamiento, sube a la superficie y tropieza con el príncipe. A los pocos días decide abandonarlo todo para ir en su busca. La urgencia con la que se desarrollan los hechos, sin el sufrimiento del enamoramiento que sí se encuentra en Andersen y que justifica la acción, contribuyen a la caracterización de esta nueva sirena: rebelde, caprichosa, consentida, irresponsable, impaciente... Ya no es un personaje misterioso y romántico, sencillamente, es una adolescente.

En el largometraje de Disney aparece una sirena que también lleva una vida regalada de princesa, sin sacrificios ni apuros. De repente, un día sube a la superficie, pero no como un verdadero acto de rebeldía, sino más bien como si fuera un capricho. Salva la vida al príncipe, se enamora de él y en pocos días busca una solución para poder ir en su busca. Con lo cual, Disney presenta un personaje aún más sesgado: una visión masculina de la sirenita como una criatura inocente y caprichosa, que gracias a su belleza consigue aquello que se propone, que casi siempre es el amor de un príncipe.

Así pues, la fase del enamoramiento es tan breve en el espacio y el tiempo en la obra de Riera, que el lector sospecha que, posiblemente, lo que siente la sirena no es el amor eterno e ideal de Andersen. De hecho, el autor danés dedica más de medio libro a contar el sufrimiento amoroso de su protagonista, porque un amor romántico necesita más tiempo [Wellek, Warren, 1966]. Su sirenita sufrió durante meses por amor, hasta que a punto 
de morir de amor, decidió ir a buscar al príncipe. De modo, que el destino se impuso, la sirenita no tenía alternativa.

En cambio, la sirena de Riera, enseguida decide ir a ver a la maga para encontrar una solución a su cola de pez y poder marcharse. Tanto en el caso de Andersen como en el de Disney, la bruja del mar tiene claras connotaciones negativas, aunque en el caso del primero está envuelta en un aura de misterio y en el caso de Disney actúa como antagonista de una manera muy plana. En el caso de Riera, la maga (no bruja) le aconseja y así adquiere un rol de oráculo:

No debería ayudarte, pero sé que si no lo hago te tendré aquí, como una lapa, enganchada, dando la lata. Eres una pesada, tozuda igual que una mula, como dicen los de arriba, obsesiva, desobediente y rebelde. ¿Quieres arruinar tu vida y tus éxitos solo porque te has enamorado? Tienes más de mujer que de sirena. Lo siento por ti. Allá arriba muchas tontas lo dejan todo para seguirlos a ellos y se rinden a sus caprichos y permiten que las moldeen a imagen y semejanza de sus deseos, dóciles, obedientes e, incluso, calladas... (Riera, 2015, pág. 43)

La sirena sube con urgencia a la superficie para encontrar a su príncipe. Atrás deja una cola de sirena, la voz, la familia y una carrera prometedora, para empezar a convivir con el dolor físico de las piernas y el corazón hecho pedazos de ver a su príncipe enamorado de una sirena, sin poder decirle que la sirena que le salvó la vida era ella.

Tanto en el caso de Andersen como en el caso de Disney, el personaje del príncipe es plano y queda difuminado, a la sombra de la protagonista. Solamente se presenta como un chico encantador, pero en realidad los lectores o espectadores saben muy poco: ¿Cómo es? ¿Qué le gusta? ¿Qué siente? En el caso de Riera, el príncipe adquiere mayor profundidad. Este, al igual que la sirena, es un adolescente mal criado que se enamora de lo imposible: la sirena que le salva la vida; pero en lugar de ir a por ella, la espera en la playa. Mientras, la sirena sufre la impotencia de no poder decirle que aquella sirena era ella. Sumidos en esta paradoja, pasan los días y el príncipe a menudo la visita en su habitación a medianoche, pero sin que la relación vaya a más. Su crueldad, intencionada o no, se hace patente cada vez que le dice que si tuviera que casarse con alguien que no fuera la sirena, la escogería a ella. La relación entre ambos personajes pronto se vicia: él no la ama, pero le gusta tenerla cerca y ella, ante un amor no correspondido, empieza a arrepentirse de todo. Sin embargo, vive en una sumisión tal que no tiene fuerzas para volver a casa. En este punto, el amor deviene una "prisión en libertad" (Riera, 2015, pág. 55), convirtiendo el amor romántico de Andersen y el amor ideal de Disney en un amor tóxico entre adolescentes contemporáneos.

La sirena acaba confesando que fue un error convertirse en mujer para gustarle al príncipe:

¡Qué error! Nunca hubiera imaginado que él solo deseara amar a una sirena. Si pudiera volver atrás, me decía, si pudiera recuperar la cola y la lengua, él me amaría para siempre y no le importaría que las escamas se incrustaran en su carne al abrazarme y no poder poseerme. Y me amaría y me desearía mucho más que ahora porque ama, sin saberlo, quien fui y no quien soy. (Riera, 2015, pág. 74) 
De este modo, Riera dedica una parte muy importante de la novela a relatar la convivencia entre el príncipe y la sirena, para mostrar lo compleja que es la relación que se establece entre ambos personajes. La sirena había huido precipitadamente de casa, en un acto de rebeldía, con la excusa del príncipe y del repentino enamoramiento; pero en un medio hostil, sola, sin poder comunicarse y ante un amor no correspondido, la sirena asume un rol pasivo y sumiso en la relación, hasta llegar a afirmar que "mi libertad consistía en estar presa en las redes de su voluntad, por muy voluble que fuera" (Riera, 2015, pág. 80). O incluso, "A veces me acariciaba la cabeza, como le había visto hacer con su perro preferido.” (Riera, 2015, pág. 81)

Es en el desenlace de la historia donde Riera se aleja de la versión de Disney, que había acompañado el texto de una manera latente, como referente hipotextual en menor medida. En el largometraje la sirenita logra casarse con el príncipe gracias a sus amigos, quienes la ayudan a esquivar las malvadas intenciones de la bruja y devolverla a las profundidades del mar. En cambio, en el final de Riera, llega el día en que el príncipe debe escoger esposa y, evidentemente, no es la sirena, sino la princesa del reino vecino, que él mismo dice que se parece a la sirena que le salvó la vida. Los dos recién casados se aman, están profundamente enamorados, y la sirena ve que en el triángulo amoroso quien está de más es ella. Al igual que en el cuento del danés, si la sirena quiere salvarse tiene que matar al joven matrimonio, durante la noche de bodas, pero es incapaz de hacerlo:

Él había sido cruel y ciego y me había abandonado; ella era inocente, sin embargo, la consideraba culpable de mi desgracia. Pero no pude. No fui capaz de clavarlo (el puñal). Sentí una compasión infinita por los dos y les perdoné la vida (Riera, 2015, pág. 87).

De este modo, a la sirena le espera el mismo destino que a la sirenita de Andersen: una muerte ineludible. Sin embargo, Riera elimina el elemento religioso: así como habíamos visto que la sirenita es recogida por las hijas del aire y condenada a vagar por la tierra durante 300 años, para ganarse un alma inmortal, la sirena contemporánea se convierte en espuma del mar y pasa a formar parte de la naturaleza con reminiscencias paganas. Desde la primera página, Riera ya había advertido explícitamente que la sirena no perseguía un alma inmortal, de modo que el lector asiste a una sistemática supresión del elemento religioso, que culmina en este final. La sirena pasa a formar parte del mar, se convierte en el rumor de las olas, condenada a contar su historia de amor no correspondido durante toda la eternidad.

\subsection{Conclusiones de una lectura hipertextual}

En el presente capítulo se ha abordado el análisis de La voz de la sirena desde la teoría de la hipertextualidad y la intertextualidad literarias de Gerard Genette, según la cual se establecen una serie de relaciones entre las distintas obras de la historia de la literatura como un hecho inevitable. Por ello, la práctica hipertextual deviene un procedimiento creativo habitual para elaborar reescrituras (hipertextos), tomando argumentos, escenas, personajes y demás elementos de obras anteriores (hipotextos). En consecuencia, el completo proceso de recepción de las obras requiere la activación de mecanismos de re- 
cepción que consientan el reconocimiento de argumentos, personajes y demás elementos hipertextuales, a partir de la experiencia lectora acumulada. En los lectores en formación es necesaria la lectura reiterada de modelos, estructuras, argumentos y personajes para que amplíen su bagaje literario, aprendan a reconocer elementos y a establecer relaciones entre estos y lecturas anteriores. De este modo, el lector en formación amplía su competencia literaria, lo cual le permitirá leer cualquier tipo de obra literaria en un futuro. Por estas razones, en la literatura infantil y juvenil del siglo XX se hallan numerosos ejemplos en los que se toma un cuento popular o popularizado y se elabora una reescritura con una intención determinada, como es el caso de La voz de la sirena de Carme Riera.

Tanto La sirenita de Andersen, como La sirenita de Disney como La voz de la sirena de Riera cuentan la misma historia protagonizada por un mismo personaje, pero con características y connotaciones distintas. A pesar de que el hipotexto base es La sirenita de Andersen, ni la autora ni el lector pierden de vista ni por un momento la trascendencia que tuvo el largometraje de Disney en la configuración del personaje. Por ese motivo, a pesar de no ser el hipotexto principal, pues la historia de Riera sigue el argumento de Andersen, el latido de la popularizada versión de Disney, entre sus líneas, es constante.

A través del cambio y la introducción de elementos nuevos -narrador, estructura y caracterización de los personajes-, Riera elabora una reescritura con una clara intención feminista, que pretende acabar con los cuentos de hadas de finales felices, a los que el lector está acostumbrado. De este modo, la autora lanza un mensaje claro y contundente al lector del siglo XXI: los cuentos de hadas al uso no existen, las chicas no tienen porqué ser las princesas bonitas y silenciosas, deben ser ellas mismas, porque al fin y al cabo el amor ideal y perfecto puede no salirles bien.

\subsection{Referencias bibliográficas}

Brasey, E. (2001). Sirenas y ondinas. Palma de Mallorca: Olañeta.

Colomer, T. (2000). De la narrativa oral a la literatura per a infants: invenció d'una tradició literària. Alzira: Bromera.

De Amo, J.M., Cleger, O. \& Mendoza, A. (2015). Redes hipertextuales en el aula. Literatura, hipertextos y cultura digital. Barcelona: Octaedro.

Díaz-Plaja, A. (2002). Les reescriptures a la literatura infantil y juvenil dels últims anys. Colomer, T. Literatura infantil i juvenil catalana. Bellaterra: Institut de Ciències de l'Educació de la Universitat Autònoma de Barcelona.

Colomer, T. \& Olid, B. Princesitas con tatuaje: Las nuevas caras del sexismo en la ficción juvenil. Disponible en julio de 2017 en http://www.gretel.cat/sites/default/files/ fitxers/documents/Princesitas.pdf

Eco, U. (2005). Sobre literatura. Barcelona: Penguin Random House.

Genette, G. (1989). Palimpsestos. La literatura en segundo grado. Madrid: Taurus.

Hürlimann, B. (1982). Tres siglos de literatura infantil europea. Barcelona: Juventud. 
March, J. (2002). Diccionario de mitología clásica. Barcelona: Crítica.

Mendoza, A. (2001). El intertexto lector. El espacio de encuentro de las aportaciones del texto con las del lector. Cuenca: Universidad de Castilla-La Mancha.

Mendoza, A. (2002). La multiplicitat de referents. En Colomer, T. (coord.). Literatura infantil i juvenil catalana. Bellaterra: Institut de Ciències de l'Educació de la Universitat Autònoma de Barcelona.

Olid, B. (2011). Les herö̈nes contraataquen. Models literaris contra l'universal masculí ala literatura infantil i juvenil. Lleida: Pagès editors.

Prats i Ripoll, M. \& Contreras i Barceló, E. (2019) Los personajes femeninos en la Literatura infantil y juvenil: dos propuestas didácticas para futuros maestros en Educación multidisciplinar para la igualdad de género. Perspectivas traductológicas, ecoartísticas, socioeducativas y jurídicas. Valencia, España: Editorial Universitat Politècnica de València.

Riera, C. (2015). La voz de la sirena. Barcelona: Lumen.

Wellek, R. (1983). Historia literaria. Problemas y conceptos. Barcelona: Laia Editorial.

Wellek, R. \& Warren A. (1966) Teoría literaria. Madrid: Gredos.

Woolf, V. (1992). Una habitación propia. Barcelona: Seix Barral 



\section{Capítulo 4 Cabrera Infante en boca de Suzanne Jill Levine: Tres Tristes Tigres en clave feminista

\author{
Robert Martínez-Carrasco \\ Eva Peñarrocha \\ Depto. de Traducción e Interpretación \\ Universitat Jaume I
}

\subsection{Introducción}

En gran medida, se podría afirmar que somos partícipes de la realidad que nos rodea a través de las traducciones y discursos parciales con que interactuamos. Sin ir más lejos, los debates actuales acerca de la posverdad y sus implicaciones sociales, culturales, económicas y políticas no han hecho sino enfatizar la naturaleza situada del conocimiento y apuntalar una concepción de la realidad en tanto que (re)negociación continua de creencias determinadas. Ese proceso colectivo de significación en que nos vemos inmersos no puede estar al margen de las relaciones de poder que se establecen en el seno de la sociedad, y por ende acaba por reforzar modelos de hibridación cultural de carácter homogeneizador, occidental y con raíces heteropatriarcales.

En ese contexto, identificar el complejo entramado de estructuras sociales que median las relaciones de poder se convierte en un elemento fundamental de cara a entender las diferentes formas de alienación y asimetrías de poder que dan forma a nuestra sociedad. El pensamiento tradicional, tal y como apunta Horkheimer, (1982, pág. 9), es incapaz de hacer frente a tal empresa, ya que, en su afán positivista de objetivar la realidad, se olvida de cómo los procesos sociales y las relaciones de poder limitan su propia naturaleza y lo desproveen de legitimidad en favor de los discursos dominantes.

Vidal Claramonte (2010), en ese sentido, describe cómo determinadas corrientes ideológicas modelan la percepción de la realidad de forma unidireccional desde las élites económicas hacia la periferia; es decir, cómo determinados discursos se enmarcan dentro 
de narrativas de inaceptabilidad y subversión mientras que otros se potencian hasta convertirse en lógicos, naturales, verdaderos e incontestables.

$\mathrm{Y}$ es en este contexto en particular donde la labor de quien traduce encuentra uno de sus principales dilemas: el de las fidelidades encontradas; sean estas hacia el cliente y lo que este representa, hacia uno mismo y sus ideales, o hacia una hipotética audiencia lectora que solo puede acceder a ciertos discursos a través de una tercera persona, traductora, que tiene en su mano no solo la llave que da acceso a un texto que sería ininteligible de cualquier otro modo, sino también la oportunidad perpetuar ciertas prácticas y actitudes o, por el contrario, posicionarse ideológicamente de forma deliberada contra determinados discursos y prácticas socialmente establecidas (Tymozcko, 2003).

Es un hecho incontestable que la lengua y, por ende, la traducción, es una herramienta de transformación social, una actividad que no puede abstraerse de lo social y lo político. La traducción plantea cuestiones éticas a cada momento ante las que el o la traductora deben decidir, de forma consciente o inconsciente, es decir, debe determinar cómo actuar respecto a esas fidelidades encontradas. Habitar la frontera entre las lenguas y los discursos, vivir en el "entre" al que hace referencia (Tymozcko, 2006, pág. 10) puede contribuir a alienar al traductor y hacerle perder su identidad y su voz como sujeto; pero, al mismo tiempo, el "entre" puede convertirse en un espacio —incómodo, eso sí- desde el que poder actuar (Godayol, 2000).

En relación a cuestiones de género y representación, como veremos abajo, la traducción contribuye a construir y moldear identidades (House, Martín Ruano \& Baumgarten, 2005, pág. 4), con lo que puede utilizarse de manera efectiva como herramienta para cuestionar el status quo y subvertir determinadas creencias e ideas. Pese a todo, este proceso emancipador sensible a cuestiones interseccionales solo puede llevarse a cabo cuando el traductor es capaz de detectar los diferentes niveles de significación textual y las narrativas que enmarcan el texto.

\subsection{Traducción, identidad y género}

Bengoechea (2015, pág. 8) reflexiona acerca del proceso de aprendizaje de la lengua materna como un proceso en que las mujeres aprenden sistemáticamente a no ser mencionadas y a aceptar la falta de referencia explícita de forma natural. Esa ausencia de mención, el verse relegadas lingüísticamente, tiene consecuencias directas en el desarrollo de la propia identidad; ya que ciertos colectivos cuentan con modelos de representación con los que pueden identificarse y ciertos otros, aquellos que se encuentran en la periferia de la realidad (mujeres, minorías étnicas, personas LGTB + , o las intersecciones resultantes) se encuentran infrarrepresentados discursiva y socialmente.

Bourdieu (2000) llega a plantearse cómo no ha habido una subversión mayor a esas prácticas discursivas heteropatriarcales basadas en criterios de exclusión e invisibilidad hacia ciertos grupos. Más bien al contrario, argumenta, la dominación parece no causar demasiado revuelo sino más bien aceptación, tanto interiorizada como externalizada, 
de ciertas minorías sociales que se ven atrapadas en relaciones de poder asimétricas. La violencia simbólica que, en forma de esquemas mentales, se interioriza de forma consciente e inconsciente, fortalece esos lazos asimétricos de poder y favorece la asimilación de ciertas prácticas discursivas por entenderlas universales.

En el campo de la traducción, a partir de los años 70 se vivió un momento sin precedentes en el que teóricas de la traducción y traductoras profesionales, conscientes de su posición subordinada y de la oportunidad que la traducción les ofrecía como herramienta de transformación social, se embarcaron en el propósito de crear lazos de solidaridad interfemeninos a través de los cuales poder subvertir el monólogo del discurso patriarcal dominante (Godard, 1990, pág. 88). En un principio, bajo el paradigma de la dominación, la lucha se centró en evitar la invisibilización del género con propuestas relacionadas con el uso no sexista del lenguaje: uso de formas pronominales en plural, uso de formas pasivas, uso del femenino genérico, uso de pronombres alternados, etc. (Mills, 1995, pág. 96-97). Sin embargo, pronto surgieron las voces que argumentaban que la transposición de elementos marcados por formas neutras no profundizaba en la falta de representación y las asimetrías de poder presentes en la sociedad. No se trataba, afirmaban, de evitar el androcentrismo inherente a las gramáticas prescriptivas, sino de luchar activamente contra la dominación heteropatriarcal ayudándose de la traducción, entendida como actividad política.

Así, en el Quebec de los años 80 y 90, un grupo de autoras y traductoras comenzó a poner en práctica toda una serie de propuestas y estrategias intervencionistas que dieron pie a lo que hoy se conoce como estudios feministas de la traducción (Brufau, 2010, pág. 50). Tildadas a menudo de revisionistas, traductoras como Barbara Godard, Suzanne Jill Levine, Luise von Flotow, Sherry Simon o Susanne Lotbinière-Harwood profundizaron en la lucha contra la opresión patriarcal con un doble propósito: construir una fuerte solidaridad entre las mujeres y desmantelar el patriarcado arraigado en la palabra escrita (Castro, 2008, pág. 289).

El vínculo entre autoras y escritoras permitió experimentar con los límites entre la autoría, la coautoría y la traducción en contextos literarios donde la intimidad y la sororidad entre mujeres, fomentada por un ideario común respecto a la lucha contra la dominación masculina, permitió entender el lenguaje como una atalaya desde la que combatir y moldear prácticas sociales determinadas y desmantelar la carga patriarcal del lenguaje y de la sociedad; enfatizando que, con sus decisiones, la traductora puede promocionar discursos prevalentes o, por el contrario, precipitar el cambio y la evolución de los mismos (Martín Ruano, 2006, pág. 218).

En cualquier caso, las técnicas de carácter lingüístico y textual que estas traductoras propusieron en su momento no han estado exentas de crítica, a menudo descontextualizada, por el alto grado de intervención de la traductora en el texto. Así, aunque en ningún momento las traductoras pretendieron universalizar sus propuestas, ceñidas a un ámbito concreto (el literario) en unas condiciones de sororidad escritora-traductora determinadas, autoras como Arrojo (1994) cargan contra algunas de estas estrategias por conver- 
tirse justamente en lo que pretenden eliminar, tildándolas, en ocasiones, de oportunistas, falsas e incongruentes, ya que, se pregunta Arrojo (ibid, pág. 157), “on what grounds can one justify that 'womanhandling' the texts is objectively positive while 'manhandling' them is to be despised?".

Las propuestas feministas que mencionamos a continuación, recogidas en Von Flotow (1991, págs. 74-80), Castro (2008, págs. 293-296) o Martínez-Carrasco y Frasquet (2015, págs. 672-674) siguen siendo a día de hoy un punto de partida para innumerables debates sobre el intervencionismo en traducción. Las pautas que estas traductoras desarrollaron nos servirán, como veremos más abajo, para analizar la traducción al inglés de la obra Tres tristes tigres, de Guillermo Cabrera Infante, a mano de Suzanne Jill Levine, traductora feminista adscrita a este movimiento.

\subsubsection{Estrategias de compensación o suplementación}

Estas estrategias tienen como objetivo explicitar lo implícito, subrayar la misoginia de forma tan directa y clara que provoque en la audiencia un sentimiento de extrañeza y rechazo, o bien todo lo contrario: neutralizar mediante una intervención directa aquellas connotaciones y marcas de género que denigren a las mujeres o las condenen al ostracismo. Entre estas estrategias se encuentran:

- La explicitación del género, sea mediante explicitaciones directas (female teacher) o marcas en negrita, como propone Lotbinière-Harwood (1991), que resalten el femenino de los textos en francés en lenguas menos marcadas por el género como el inglés ("Nulle ne l'ignore, tout est langue" por "No one ignores the fact that everything is language").

- Compensaciones dentro del texto, como propone Scott cuando traduce a Bersianik (1984), donde "le ou la coupable doit être punie" se convierte en "the guilty one must be punished, whether she is a man or a woman".

- Uso de dobletes ("he/she")

- Uso de dobletes sexualizados ("les héros" por "the heroes and heroines")

- Uso de fórmulas neutras ("Québecois" por "Québecois people”)

- Uso de la explicitación masculina cuando no se trata de un masculino neutro

- Uso de términos que engloban a hombres y mujeres ("man" por "human being", o "la victoire de l'homme" por "our victory")

\subsubsection{Estrategias de metatextualidad}

Mediante las estrategias de metatextualidad se enfatiza el papel activo de la traductora $\mathrm{y}$, mediante el uso de paratextos de todo tipo (prefacios, notas al pie, etc.) se analizan, entre otros, las intenciones políticas del texto original y justifican las traducciones e intervenciones textuales de la traductora. Los paratextos acompañan al texto traducido y tienen una finalidad didáctica clara para quien lo lee, es decir, la traductora educa al 
lector o lectora y contextualiza (dejando a veces en evidencia) el texto en sí y el contexto que lo rodea.

\subsubsection{Estrategias de secuestro}

Estas estrategias consisten en el secuestro del texto original, pues la traductora se apropia de la obra e introduce, entre otros, cambios en el contenido que poco tienen que ver con el original, neologismos que propician una perspectiva feminista del texto, el femenino genérico, formas inclusivas, la inversión de elementos sexistas, etc. Como apuntan Martínez-Carrasco y Frasquet (2015, pág. 673), un ejemplo clásico es el que proporciona Von Flotow (1991, pág. 69) en que, desde el original Ce soir, j'entre dans l'histoire sans relever ma jupe, se analizan dos traducciones: una hecha por un hombre (Tonight I'm entering history without lifting up my skirt) y otra hecha por la feminista Linda Gaboriau (This evening I am entering history without opening my legs).

\subsubsection{Estrategias de coautoría}

Se trata de estrategias de coautoría entre la escritora y la traductora encargada de realizar la traducción o performance - término que Lotbinière-Harwood (1991) y von Flotow (1999) utilizan para referirse al acto de traducción — fortaleciendo de ese modo la solidaridad interfemenina y la "re-escritura en femenino".

\subsection{Tres tristes tigres}

Tres Tristes Tigres forma parte del parte del boom de literatura latinoamericana de los años 60 y es considerada una de las obras más innovadoras de este periodo. Su autor, Guillermo Cabrera Infante, trabajó como agregado cultural en Bruselas hasta que, en 1968, tras el primer gobierno de Fidel Castro, criticara en una entrevista el nuevo gobierno del régimen, lo que provocó su cese como diplomático y lo obligó a partir al exilio.

La novela en cuestión está ambientada en La Habana de 1958 y pretende mostrar una imagen fidedigna de la vida nocturna de la ciudad en ese momento histórico. Cabe mencionar, en relación con el estudio que presentamos, que ningún personaje femenino aparece en la obra por sí solo sino en relación a alguno de los personajes masculinos o a causa de los mismos. Otro aspecto destacable son los numerosos juegos de palabras empleados por el autor con los que pretende, y él mismo advierte de sus intenciones al inicio de la novela, dar sabor cubano a las palabras que conforman su texto. La obra resultante, fuertemente oral y plagada de referencias y guiños a otras obras literarias, hace de Tres Tristes Tigres una obra compleja de gran riqueza lingüística. Asimismo, aparecen fragmentos en inglés en boca de personajes bilingües y se cuida el idiolecto de los personajes hasta el punto de que la caracterización de algunos de ellos recurre a faltas de ortografía al plasmar el diálogo por escrito.

La novela está dividida en tres fragmentos independientes. En el primero de ellos se presentan tres personajes femeninos: Vivian Smith-Corona, Cuba Venegas y La Estrella. La primera de ellas es hija de una familia adinerada; la segunda, una joven que huye del 
campo y encuentra la fama en La Habana por su indudable atractivo físico; y la tercera, "la ballena negra", es una aspirante a cantante. En los tres casos la representación parece ser la misma: la de un objeto sexual o un adorno que acompaña a la figura masculina. En el caso de La Estrella, si cabe, la representación es todavía más grotesca. Como veremos más adelante, es precisamente en la representación de estos personajes donde la voz de la traductora cobra mayor vida.

En la segunda parte el autor recopila distintos relatos sobre la muerte de Trotski desde el punto de vista de diferentes escritores cubanos, un cambio que rompe con el hilo de la historia y que conduce al tercer y último bloque, donde Arsenio Cué y Silvestre, a modo de personajes principales, viven una noche de fiesta por La Habana. A través de monólogos y conversaciones entre ellos, los personajes reflexionan sobre literatura, filosofía y otras cuestiones de calado que contrastan con las partes de la obra donde aparecen personajes femeninos, donde los diálogos y las descripciones se centran únicamente en su físico y su sexualidad.

La traducción de la obra al inglés se le encarga a Suzanne Jill Levine en colaboración con el mismo Cabrera Infante seis años después de la publicación de Tres tristes tigres en 1961. Levine, traductora, escritora y teórica de la traducción, es actualmente directora del programa de doctorado de Traducción de la Universidad de California en Santa Bárbara y reconocida como una de las traductoras de literatura latinoamericana del siglo XX más relevantes. Ha traducido novelas de autores como Guillermo Cabrera Infante, Manuel Puig o Jorge Luis Borges, y cuenta con una obra propia, The Subversive Scribe (1991), en la que expone los problemas de traducción con los que se ha encontrado al trabajar con novelas latinoamericanas y justifica algunas de sus decisiones traductoras.

Asimismo, Levine está considerada como parte del colectivo de traductoras feministas, entre las que destaca por aplicar las estrategias propias de esta corriente en obras ajenas al feminismo, escritas por autores varones. En The Subversive Scribe, donde la autora incluye un epílogo titulado "Traduttora, tradittora" encaminado a exponer su intervención como traductora feminista, la propia Levine (1991, pág. 182) justifica el empleo de técnicas y estrategias de traducción intervencionistas señalando que: "A woman is like a translation: unfaithful if beautiful. But as the madwoman says at the very end of TTT [Three Trapped Tigers], I “can't go no further." I can only question the belief system that uses these terms to define woman and translation".

Cabe destacar que en realidad la traducción de Levine no es la primera traducción al inglés de Tres tristes tigres, sino que se trata de una adaptación al inglés norteamericano de una traducción previa del poeta inglés Donald Gardner (Levine, 1975, pág. 268-269). Además, el hecho de que Levine tradujera mano a mano con el autor de la obra ofrece posibilidades muy interesantes para el análisis del producto final, ya que no solo el autor del manuscrito tuvo voz en el proceso de traducción de la obra sino que, años más tarde, volvió a confiar en Levine para la traducción de su siguiente libro, La Habana para un infante difunto (1979). 


\subsection{Tres tristes tigres en clave feminista}

A continuación, rememoradas las técnicas y estrategias de traducción que las traductoras del Quebec propusieron en su momento para subvertir el patriarcado y su lenguaje, se analiza la traducción a manos de Levine de la obra Tres Tristes Tigres, traducida al inglés como Three Trapped Tigers.

- Estrategias de compensación o suplementación:

Las estrategias de compensación o suplementación son de las más empleadas en la traducción de Levine. A lo largo de la novela, encontramos ejemplos de sobretraducción, de empleo de términos y fórmulas neutras, de dobletes y de explicitación de marcas de género tanto femenino como masculino.

No obstante, la técnica de compensación que más destaca — a causa del grado de intervención que supone - es la de sobretraducción. En la mayoría de los casos, el uso de esta técnica está estrechamente ligado a la aparición de referencias sexuales, que, como vemos a continuación, resultan mucho más explícitas y menos eufemísticas en la traducción al inglés que en el original de Cabrera Infante.

Tabla 1. Uso de la complementación en Tres tristes tigres: sobretraducción

\begin{tabular}{|c|c|}
\hline Text & Tra \\
\hline $\begin{array}{l}\text { Lo que no le dijimos nunca a nadie fue que } \\
\text { nosotras también hacíamos cositas debajo del } \\
\text { camión. }\end{array}$ & $\begin{array}{l}\text { But what we never told anyone was that we } \\
\text { used to play with each other's things under } \\
\text { the truck. }\end{array}$ \\
\hline $\begin{array}{l}\text { Es muy difícil, pero lo mejor es decírtelo de } \\
\text { una vez. Ya no soy señorita. }\end{array}$ & $\begin{array}{l}\text { It's very difficult. But the best thing is to come } \\
\text { clean with it. I am no longer a virgin. }\end{array}$ \\
\hline $\begin{array}{l}\text { —Sí viejo sí. Códac me la presentó. } \\
\text { —Esas mujeres no se presentan, se regalan. }\end{array}$ & $\begin{array}{l}\text {-Yes, viejo. Códac introduced me. } \\
\text { - You don't introduce women like these, you } \\
\text { make love at first sight. }\end{array}$ \\
\hline $\begin{array}{l}{[\ldots] \text { era un placer físico, profundo como el }} \\
\text { coito }[\ldots]\end{array}$ & $\begin{array}{l}{[\ldots] \text { it was a physical pleasure as deep as }} \\
\text { fucking }[\ldots]\end{array}$ \\
\hline$[\ldots]$ mejor que las imaginaciones eróticas $[\ldots]$ & {$[\ldots]$ better than masturbatory fantasies $[\ldots]$} \\
\hline ¿No era más fácil enamorarlas? & Wouldn't it be easier to make love to them? \\
\hline $\begin{array}{l}\text { Vi a una muchacha, casi una muchachita, } \\
\text { como de } 16 \text { años, que me miraba. }\end{array}$ & $\begin{array}{l}\text { I saw a girl, almost too young for consent, } \\
\text { about sixteen, staring hard at me. }\end{array}$ \\
\hline $\begin{array}{l}{[\ldots] \text { las dos traían pantalones, pantalones largos }} \\
\text { más apretados que he visto en mi vida entera. }\end{array}$ & $\begin{array}{l}{[\ldots] \text { the two of them were wearing men's pants }} \\
\text { though tighter than I have ever seen, tight } \\
\text { everywhere but tighter in the wrong places if } \\
\text { you know what I mean. }\end{array}$ \\
\hline Dispuso las fotos. Eran grandes: & $\begin{array}{l}\text { She was on the bed arranging the photos in } \\
\text { which her breasts were displayed naked. They } \\
\text { were large. I mean the photos }\end{array}$ \\
\hline $\begin{array}{l}\text { Cuba Venegas }[\ldots] \text { toda de azul celeste de } \\
\text { arriba abajo. }\end{array}$ & $\begin{array}{l}\text { Cuba Venegas }[\ldots] \text { dressed in sky blue from } \\
\text { tits to toes. }\end{array}$ \\
\hline
\end{tabular}

Fuente: Elaboración propia (2018) 
Por otra parte, se constata el uso de dobletes que permiten evitar el empleo del masculino como genérico. A pesar de que no es un recurso abundante en la traducción de la obra, no es demasiado infrecuente encontrar algunos ejemplos:

Tabla 2. Uso de la complementación en Tres tristes tigres: uso de dobletes.

\begin{tabular}{|c|c|}
\hline Texto original & Traducción \\
\hline $\begin{array}{l}\text { Era un Narciso que dejaba caer sus palabras } \\
\text { en el estanque de la conversación y se oía } \\
\text { complacido en las ondas sonoras que creaba. }\end{array}$ & $\begin{array}{l}\text { He was a Narcissus-cum-Echo who let his } \& \\
\text { her words fall into the pool of conversation } \\
\text { and then listened to himself rapturously in the } \\
\text { ripples of sound she made. }\end{array}$ \\
\hline $\begin{array}{l}\text { [...] los padres de Vivian, los esposos Smith } \\
\text { Corona Álvarez del Real. }\end{array}$ & $\begin{array}{l}\text { [...] Vivian's mother and father, Mr. and Mrs. } \\
\text { Smith-Corona Alvarez de Real. }\end{array}$ \\
\hline $\begin{array}{l}{[\ldots] \text { y el hombre hablaría, por lo menos en esta }} \\
\text { parte del mundo, una enorme lingua franca. }\end{array}$ & $\begin{array}{l}{[\ldots] \text { and man (and/or woman) would speak }} \\
\text { at least in this partition of the world }[\ldots] \text { an } \\
\text { enormous lingua franca. }\end{array}$ \\
\hline $\begin{array}{l}\text { —Algún día tendrá su merecido — dijo Cué—y } \\
\text { le pondrán su nombre solo a los predestinados. }\end{array}$ & $\begin{array}{l}\text { - Someday he'll get his due, Cué said, —and } \\
\text { mothers will name their boys and girls after } \\
\text { him. }\end{array}$ \\
\hline
\end{tabular}

Fuente: Elaboración propia (2018)

Respecto al empleo de términos y las fórmulas neutras, se observa que su uso es bastante más recurrente. Sin embargo, debemos tener en cuenta que el inglés, al tratarse de una lengua que apenas cuenta con marcas de género, facilita la utilización de fórmulas y sustantivos neutros, por lo que resulta difícil discernir si esta técnica se ha aplicado de forma consciente y deliberada o si su uso se debe únicamente a las particularidades de la lengua meta. Entre los ejemplos seleccionados a continuación vemos como, en el primero de ellos, la elección de un término neutro sí es intencionada; no obstante, en el resto podría tratarse simplemente de la carencia de marcas de género de la lengua inglesa. 
Tabla 3. Uso de la complementación en Tres tristes tigres: uso de fórmulas neutras.

\begin{tabular}{|c|c|}
\hline Texto original & Traducción \\
\hline $\begin{array}{l}\text { No molesten. Estoy diseñando un hermoso } \\
\text { varón de ocho libras. }\end{array}$ & $\begin{array}{l}\text { Do not disturb. I am designing a beautiful } \\
\text { eight-pound baby. }\end{array}$ \\
\hline $\begin{array}{l}{[\ldots] \text { los felices, los amargados y los ingeniosos }} \\
\text { y los retardados mentales y los cerrados y los } \\
\text { abiertos y los alegres y los tristes y los feos y } \\
\text { los bellos y los lampiños y los barbudos y los } \\
\text { altos y los bajos y los siniestros y los claros y } \\
\text { los fuertes y los débiles y los poderosos y los } \\
\text { infelices, ah y los calvos. }\end{array}$ & $\begin{array}{l}{[\ldots] \text { the happy and the sad, geniuses and }} \\
\text { morons, the open and the inhibited and the } \\
\text { cheerful and the gloomy and the ugly and the } \\
\text { beautiful and damned and the bearded and the } \\
\text { shaven and those with five-o'clock shadows } \\
\text { and the tall and the short and the vicious and } \\
\text { the innocent and the strong and the weak and } \\
\text { the meek inheritors and the immortal and all } \\
\text { the bald people, too. }\end{array}$ \\
\hline «El opio es la religión de los chinos». & "Opium is the religion of the Chinese". \\
\hline $\begin{array}{l}\text { Se ruega a los señores automovilistas que } \\
\text { transiten por Tercera o Séptima }[\ldots]\end{array}$ & $\begin{array}{l}\text { Drivers are requested to go down Third or } \\
\text { Seventh }[. . .]\end{array}$ \\
\hline $\begin{array}{l}\text { Los hijos no se piensan ni siquiera se sienten } \\
\text { o se ven venir. }\end{array}$ & $\begin{array}{l}\text { Children-you don't think about them, you } \\
\text { don't even feel about them, nor do they seem } \\
\text { to come. }\end{array}$ \\
\hline
\end{tabular}

Desde el punto de vista opuesto, es decir, el de la explicitación del género, se observa cómo la traductora, debido una vez más a que el inglés cuenta con muchas menos marcas de género que el castellano, en muchos casos recurre a la explicitación del masculino o del femenino para diferenciar aquellos términos que sí pretenden englobar a ambos géneros de aquellos que deberían estar marcados por el género femenino o el masculino:

Tabla 4. Uso de la complementación en Tres tristes tigres: explicación masculina.

\begin{tabular}{|l|l|}
\hline \multicolumn{1}{|c|}{ Texto original } & \multicolumn{1}{|c|}{ Traducción } \\
\hline $\begin{array}{l}\text { Chaicovski pudiera haber sentado a su } \\
\text { secretario en las rodillas. }\end{array}$ & $\begin{array}{l}\text { - Tchaikovsky would have been able to sit a } \\
\text { male secretary on his knee. }\end{array}$ \\
\hline $\begin{array}{l}{[\ldots] \text { y nosotros, cada uno de su público, éramos }} \\
\text { Ulises amarrado al mástil de la barra. }\end{array}$ & $\begin{array}{l}{[\ldots] \text { and we, every man in her public, we were }} \\
\text { so many Ulysseses lashed to the mast of the bar. }\end{array}$ \\
\hline $\begin{array}{l}{[\ldots] \text { trajo a la casa un cocinero, un negrito que }} \\
\text { la obedecía. }\end{array}$ & $\begin{array}{l}{[\ldots] \text { she brought a cook into the house, a little }} \\
\text { Negro boy. }\end{array}$ \\
\hline $\begin{array}{l}{[\ldots] \text { y todo todo todo el mundo occidental tuvo }} \\
\text { que reírse. }\end{array}$ & $\begin{array}{l}{[\ldots] \text { and every but every playboy in the western }} \\
\text { world roared with laughter. }\end{array}$ \\
\hline
\end{tabular}

Fuente: Elaboración propia (2018)

Si analizamos la explicitación del masculino y del femenino a lo largo del texto, una tendencia clara que puede observarse es cómo esta técnica es bastante más frecuente cuando se trata de explicitar el género femenino. Para ello, la traductora emplea tres técnicas dis- 
tintas: incluir explícitamente los términos "female" o "woman" como antecedentes a un sustantivo neutro, utilizar extranjerismos —es decir, mantener un término español que es reconocible en el repertorio de la lengua inglesa - y, por último, anteponer la partícula "she-" al sustantivo correspondiente.

El tercero de los ejemplos que mostramos a continuación es particularmente significativo porque no solo emplea el término "female", sino que además la traductora recurre a la intertextualidad, en concreto a Porcia, personaje de la obra de Shakespeare en El mercader de Venecia. Como hemos mencionado anteriormente, la obra original está plagada de intertextualidades y referencias a otras obras literarias, con lo que este recurso se adapta de forma fluida al espíritu del texto original.

Tabla 5. Uso de la complementación en Tres tristes tigres: explicitación femenina.

\begin{tabular}{|l|l|}
\hline \multicolumn{1}{|c|}{ Texto original } & \multicolumn{1}{|c|}{ Traducción } \\
\hline$[\ldots]$ esa mulata se llamaba Maruja Suárez $[\ldots]$ & $\begin{array}{l}{[\ldots] \text { that } \text { mulata } \text { who was once Gloria Pérez }} \\
{[\ldots]}\end{array}$ \\
\hline$[\ldots]$ ver las fotos de las bailarinas españolas. & $\begin{array}{l}{[\ldots] \text { to take a look at the photos of Spanish }} \\
\text { bailaoras. }\end{array}$ \\
\hline $\begin{array}{l}{[\ldots] \text { la oratoria de la peticionaria ganó el favor }} \\
\text { de la corte callejera. }\end{array}$ & $\begin{array}{l}{[\ldots] \text { the oratory of this female Portia won the }} \\
\text { support of the sidewalk court. }\end{array}$ \\
\hline La pintora italiana del Renacimiento $[\ldots]$ & $\begin{array}{l}\text { The Italian woman painter in the Renaissance } \\
{[\ldots]}\end{array}$ \\
\hline $\begin{array}{l}\text { No te alarmes, Silver Tray, que otra insistía en } \\
\text { apodarlo el Ciego de Bonn. }\end{array}$ & $\begin{array}{l}\text { Don't be upset, Silver Tray, another she-pupil } \\
\text { insisted on describing LVB as the Blind Man } \\
\text { of Bonn. }\end{array}$ \\
\hline $\begin{array}{l}\text { Las que no sean de talle gracioso de andar } \\
\text { salamero con gracia simpar esas no son } \\
\text { cubanas. }\end{array}$ & $\begin{array}{l}\text { Those who do not walk with an easy pace, with } \\
\text { an unequaled grace, those are not she-Cubans. }\end{array}$ \\
\hline $\begin{array}{l}\text { Nuestras pasajeras reían }[\ldots] \\
{[\ldots] \text { una mulata pasó }[\ldots]}\end{array}$ & $\begin{array}{l}\text { Our she-fellow-travelers were cracking up }[\ldots] \\
{[\ldots]}\end{array}$ \\
\hline
\end{tabular}

Fuente: Elaboración propia (2018)

Si bien en nuestro análisis encontramos muestras de todas las técnicas de compensación o suplementación, cabe señalar que durante el transcurso de la novela hallamos un buen número de casos en los que, a pesar de que podrían haberse aplicado las técnicas que acabamos de enumerar, la traductora opta por no utilizarlas. Un caso especialmente llamativo es el del término "hombre", ya que en diversas ocasiones se emplea con el significado de "persona" o "ser humano" en la obra original. Sin embargo, Levine decide no alterarlo en su traducción y recurrir a "man" con el mismo propósito (el del masculino genérico) que en el Tres tristes tigres escrito en lengua castellana. Entre ellos figuran los siguientes: 
Tabla 6. Uso de la complementación en Tres tristes tigres: uso del masculino genérico.

\begin{tabular}{|c|c|}
\hline Texto original & Traducción \\
\hline $\begin{array}{l}\text { ¿No será el hombre una criatura que se exhibe } \\
\text { ante el cosmos en este enorme convertible del } \\
\text { mundo? }\end{array}$ & $\begin{array}{l}\text { Isn't man a creature who exhibits himself to } \\
\text { the cosmos in this enormous convertible we } \\
\text { call the world? }\end{array}$ \\
\hline $\begin{array}{l}\text { Moraleja: Todos los hombres son mortales, } \\
\text { pero algunos hombres son más mortales que } \\
\text { otros. }\end{array}$ & $\begin{array}{l}\text { Moral: All men are mortal, but some men are } \\
\text { more mortal than others. }\end{array}$ \\
\hline $\begin{array}{l}{[\ldots] \text { otro cartel advertía, NO CORRA, cuide la }} \\
\text { vida de nuestros niños. }\end{array}$ & $\begin{array}{l}{[\ldots] \text { another sign read SLOW DOWN-YOU }} \\
\text { ARE RISKING THE LIVES OF OUR SONS. }\end{array}$ \\
\hline $\begin{array}{l}{[\ldots] \text { su sistema de nuevo bautizo de hermanos }} \\
\text { en que todos tendrían diferentes apellidos }[\ldots]\end{array}$ & $\begin{array}{l}{[\ldots] \text { his new system for baptizing brothers in }} \\
\text { which they'd all have different last names }[\ldots]\end{array}$ \\
\hline $\begin{array}{l}\text { Encontramos a Irenita y una amiga sin nombre } \\
{[\ldots]}\end{array}$ & $\begin{array}{l}\text { We met Irenita plus some nameless friend of } \\
\text { hers [...] }\end{array}$ \\
\hline $\begin{array}{l}\text { Subimos a su apartamento. Esta noche se llena } \\
\text { con alumnas del conservatorio }[\ldots]\end{array}$ & $\begin{array}{l}\text { We go back again to his apartment. This night } \\
\text { is filled with pupils from the conservatory }[\ldots]\end{array}$ \\
\hline
\end{tabular}

Fuente: Elaboración propia (2018)

- Estrategias de secuestro del texto original:

El secuestro, o hijacking, es la estrategia por la que se reconoce especialmente a Levine como traductora feminista. Como indicábamos anteriormente, la traductora no duda en aplicar esta técnica a obras de autores masculinos cuya temática es completamente ajena al feminismo, algo no tan frecuente entre sus compañeras traductoras. Tres tristes tigres no es una excepción, y el secuestro de la obra original contrasta con el contexto sexista o denigrante hacia las mujeres que refleja la obra de Cabrera Infante en algunas de sus páginas.

En la traducción de Levine esta técnica en cuestión se materializa a través de las continuas intervenciones de la traductora en el texto dado que, como vemos a continuación, la traductora incluye desde oraciones hasta fragmentos completos que no aparecen en la obra original, hasta el punto de que la novela en inglés cuenta con aproximadamente 30 páginas más que la obra de Cabrera Infante. 
Tabla 7. Uso del secuestro en Tres tristes tigres: explicitación.

\begin{tabular}{|c|c|}
\hline Texto original & Traducción \\
\hline $\begin{array}{l}{[\ldots] \text { y entran dos mujeres, desnudas. Luego }} \\
\text { entra un hombre - un negro era, que se veía } \\
\text { más negro por la iluminación- parecen } \\
\text { divertirse mucho con todo. }\end{array}$ & $\begin{array}{l}\text { [...] two women come in stark naked. They } \\
\text { lie down on the bed and start caressing each } \\
\text { other, making love and other things which are } \\
\text { disgusting and unhygienic. Then a man comes } \\
\text { in -a Negro, of course, but looking blacker } \\
\text { than usual in this lighting- with an excessively } \\
\text { long member and all three of them seem to get } \\
\text { a big kick out of all sorts of variations on the } \\
\text { theme. }\end{array}$ \\
\hline $\begin{array}{l}\text { [Fragmento completo que no aparece en el } \\
\text { texto original] }\end{array}$ & $\begin{array}{l}\text { I opened her zipper and slid my hand right down } \\
\text { inside below her waist and she wiggled and } \\
\text { twisted, but I don't think I was putting her off } \\
\text { at all. She wasn't wearing a bra and that was the } \\
\text { very first thing that surprised me. We followed } \\
\text { the same kiss along and she was biting my lips } \\
\text { real hard and saying some nothing or other at } \\
\text { the same time. I slid my hand round the side of } \\
\text { her back toward her breasts and at least I felt } \\
\text { them, small but seeming to bud, to blossom, to } \\
\text { develop nipples under my hand. }\end{array}$ \\
\hline $\begin{array}{l}{[\ldots] \text { y volvía a entrar y ellos volvían a }} \\
\text { acariciarse. }\end{array}$ & $\begin{array}{l}{[\ldots] \text { when the old lady was safe inside, she'd }} \\
\text { turn her head and then he took out his thing and } \\
\text { she began to touch it, to run her hand over it, } \\
\text { and then fondling it, she would look out to see } \\
\text { if the old woman was coming or not, then she } \\
\text { got up from the rocking chair, picked up her } \\
\text { skirts and sat in his lap and she began moving } \\
\text { and he began rocking. }\end{array}$ \\
\hline $\begin{array}{l}\text { Se le murió un tipo conque ella andaba en } 11 \\
\text { y } 24 .\end{array}$ & $\begin{array}{l}\text { This girl killed a fellow she was going with. } \\
\text { She just pulled her cunt on him right there in } \\
\text { the hotel on 11th and } 24 \text { th streets. }\end{array}$ \\
\hline $\begin{array}{l}{[\ldots] \text { empiezo a decirle que hace calor, que es }} \\
\text { una lástima que se esté echando a perder el } \\
\text { vestido. }\end{array}$ & $\begin{array}{l}{[\ldots][\mathrm{I}] \text { begin telling her how hot it is and that }} \\
\text { it's a pity she's going to fuck - pardon- to } \\
\text { wreck her dress. }\end{array}$ \\
\hline
\end{tabular}

Fuente: Elaboración propia (2018)

En la mayoría de casos, como comprobamos en ejemplos anteriores, esta adición se produce cuando se dan en la obra original fragmentos sexualmente explícitos. En términos generales, el objetivo de estas adiciones no es subvertir o suavizar esos elementos sexistas, sino todo lo contrario: contribuir a reforzar el estereotipo y fomentar en el lector el rechazo hacia una situación denigrante o sexista en concreto. Pese a todo, en algunas 
ocasiones Levine combina esta postura con su contraria, la de matizar o suavizar esos mismos elementos:

Tabla 8. Uso del secuestro en Tres tristes tigres: neutralización.

\begin{tabular}{|l|l|}
\hline Texto original & Traducción \\
\hline $\begin{array}{l}{[\ldots] \text { me contó casi todas sus desgracias, pero }} \\
\text { no las voy a repetir aquí porque él me las contó } \\
\text { en confidencia y yo soy un hombre y no voy a } \\
\text { andar chismeando. }\end{array}$ & $\begin{array}{l}{[\ldots] \text { he told me all his troubles, confidentially, }} \\
\text { and many other things, always confidentially, } \\
\text { but'm not going to repeat them because I'm a } \\
\text { photographer not a press gossip. }\end{array}$ \\
\hline $\begin{array}{l}{[\ldots] \text { ni artista ni técnico ni artesano ni obrero ni }} \\
\text { científico ni lumpen ni puta. }\end{array}$ & $\begin{array}{l}{[\ldots] \text { neither artist nor technician nor artisan nor }} \\
\text { worker nor scientist nor lumpenproletariat nor } \\
\text { prostitute. }\end{array}$ \\
\hline $\begin{array}{l}{[\ldots] \text { vi a Cuba entera, como está, más alta y y }} \\
\text { más bella y más puta que nunca. }\end{array}$ & $\begin{array}{l}\text { I saw Cuba, every inch of her, bigger and more } \\
\text { beautiful and sexier than ever. }\end{array}$ \\
\hline $\begin{array}{l}\text { Hizo una mímica exagerada del acto de escribir } \\
\text { que más que la caricatura de un escritor era la la } \\
\text { de una mecanógrafa. }\end{array}$ & $\begin{array}{l}\text { He went through an exaggerated mime of } \\
\text { someone typing. It was bad typecasting. }\end{array}$ \\
\hline
\end{tabular}

Fuente: Elaboración propia (2018)

Por último, cabe añadir que en la traducción de Tres tristes tigres no encontramos ejemplos de otras técnicas de secuestro controvertidas como la creación de neologismos o el empleo del femenino genérico que sí aparecen de forma sistemática en las traducciones de otras de sus coetáneas traductoras.

- Estrategias de coautoría:

Otra estrategia presente en la traducción de Tres tristes tigres es la coautoría. Como señala Levine en The Subversive Scribe (1991: xi) la traducción al inglés es fruto de una colaboración con Cabrera Infante, hecho que la traductora considera positivo, puesto que de este modo: "I wouldn't be accused of profaning a sacred script, because the author himself would be the first traditore".

Si bien en este caso la coautoría no responde a los objetivos establecidos por las teóricas feministas, pues tratándose de un autor varón su finalidad no sería en ningún caso la de promover la sororidad entre mujeres, la coautoría sí le sirve a Levine para dar una mayor visibilidad al papel de la traductora y mostrarla como una creadora activa, en tanto que "far from the traditional view of translators as servile, nameless scribes, the literary translator can be considered a subversive scribe" (ibid, 1991, pág. 7). Asimismo, el hecho de trabajar con el autor de la obra otorga una mayor legitimidad a la traductora, especialmente en el caso de aquellas intervenciones que puedan considerarse más controvertidas, dado que toda manipulación del texto original cuenta con la aprobación de Cabrera Infante.

Conviene apuntar, eso sí, que algunas de las adiciones incluidas en apartados anteriores en este trabajo pueden no deberse únicamente a la aplicación por parte de la traductora 
de la técnica de secuestro de la obra original sino a la coautoría entre Levine y Cabrera Infante durante el proceso de traducción de la novela. Sin embargo, resulta imposible discernir en qué casos las adiciones se deben a una técnica en particular o a otra, ya que ni por parte del autor ni por parte de la traductora hay reflexiones posteriores a la traducción de la obra donde se mencionen explícitamente los procesos de creación discursiva entre ambos.

- Estrategias de metatextualidad:

Por último, y desafortunadamente, la traducción de Tres tristes tigres de Levine prescinde de la estrategia de la metatextualidad. A lo largo de la obra no se encuentra ningún tipo de prólogo, nota al pie u otro tipo de paratexto en el que la traductora justifique sus decisiones o explique la finalidad política de su traducción.

Resulta curioso que, a pesar de la estrecha relación entre el autor y la traductora a causa de la colaboración entre ambos durante el proceso de traducción de Tres tristes tigres, Levine no pidiera a Cabrera Infante incluir un prólogo en el que expusiera su intención de suavizar o exagerar los elementos sexistas contenidos en el original. Se trata de un hecho que contrasta con la práctica de otras traductoras de la misma corriente, para quienes intervenir con fines feministas en la traducción de una obra no tiene sentido si dicha intervención no se anuncia mediante paratextos y otros elementos. En lugar de ello, tal y como afirma Brufau (2009, pág. 369), Levine explica brevemente su intervención como traductora feminista en el epílogo de The Subversive Scribe (1991), a pesar de que su justificación hubiera alcanzado un público mucho más amplio de haberla incluido en Three Trapped Tigers en lugar de hacerlo en una obra especializada de Traductología.

\subsection{Discusión y conclusiones}

Como puede observarse a través de la sucinta selección de ejemplos que presentamos, Levine pone en práctica de forma sistemática las estrategias de traducción por las que advoca, a falta de la presencia de paratextos que acompañen la lectura de la obra. Sin duda alguna, un prefacio a su traducción o notas al pie en los momentos más controvertidos de la misma hubieran podido ilustrar no ya solo el producto final, sus Three Trapped Tigers, sino el proceso de traducción en sí mismo y el hilo conductor que lleva a la traductora a tomar decisiones y a moldear el texto de determinada manera. Levine crea, re-crea y trans-crea, junto con Cabrera Infante, en un ejercicio de negociación continua de lo que constituyen las fronteras de la traducción, las atribuciones profesionales de la traductora y las expectativas sociales sobre la profesión en sí.

El ejemplo de Levine no hace sino subrayar el carácter situado de la actividad traductora, es decir, cómo las experiencias de quien traduce, al igual que aquellas de quien escribe, no pueden separarse de la cultura y el contexto que las rodea, ni de su propia identidad. Pese al revuelo, el debate y las críticas que las traductoras feministas recibieron en su momento, las traducciones y las reflexiones que las acompañaron ponen de manifiesto una idea principal, que la deshumanización que se supone de los traductores, es decir, 
aquellas metáforas de la traducción como un puente, o un espejo, o un embudo, son una quimera. En tanto que sujetos cognoscentes, los traductores toman decisiones a cada momento en función de unas reglas explícitas (especificaciones del cliente, expectativas de una audiencia lectora) e implícitas (parámetros socio-culturales, etc.), y aquellos que se vanaglorian de su imparcialidad y su neutralidad o bien de forma activa suscriben las motivaciones, expectativas y parámetros de exclusión de las estructuras de poder imperantes, o bien, simplemente, no son conscientes de las mismas y su labor, o por desconocimiento, contribuye a perpetuarlas.

Extrapolando la revolución que supuso que un grupo de mujeres feministas decidiera subvertir, desafiar y exponer la carga patriarcal que subyace en los discursos imperantes, debemos plantearnos a día de hoy cuál es el papel y la responsabilidad de los traductores y traductoras respecto a la norma, así como su sensibilidad hacia los discursos periféricos. La toma de conciencia, es decir, ser capaz de detectar aquellos elementos problemáticos que se presentan como naturales en los discursos imperantes, es el primer paso a partir del cual desarrollar una percepción consciente no solo del mensaje que se pretende traducir, sino de la posición, muchas veces privilegiada, desde la que uno percibe el mensaje.

El reto, además, consiste en ampliar el debate a otras áreas de la traducción. Si bien hemos visto con el ejemplo de Levine y Cabrera Infante que en el ámbito literario un mayor o menor grado de intervención podría llegar a consensuarse entre los diferentes actores del proceso, podríamos plantearnos qué sucede con otros tipos de traducción (la traducción jurídica, la traducción científica) donde el debate sobre la fidelidad y la literalidad ha tomado tradicionalmente caminos diferentes. ¿Se puede traducir el lenguaje de la ley en clave feminista?, se pregunta Brufau (2008). ¿Cuáles serían sus escollos y cómo se diferencian estos de la traducción literaria?

Igualmente importantes son los debates sobre la automatización de la traducción y la perspectiva de género. Con un avance exponencial en las tecnologías de procesamiento del lenguaje natural y la introducción de big data a través de enormes corpus textuales en grandes redes neuronales (Casacuberta \& Peris, 2017), las perspectivas de la traducción tal y como la conocemos ahora parecen tambalearse en un futuro no muy lejano; y aunque la traducción literaria dista mucho de los textos altamente sistematizables con los que la traducción automática neuronal funciona con mayor índice de éxito, ya comienzan a existir, de forma puramente experimental, plataformas capaces de detectar las características estilísticas de un autor, e intentar reproducirlas.

La deshumanización de la traducción parece, pues, cuestión de tiempo, y con ella su transformación en una tecnología foucaultiana indiferente a la intersubjetividad y la intercomunicación discursiva que la caracteriza, al menos según conceptualizaciones contemporáneas. Esa progresiva automatización no hace sino reducir el "entre", la frontera desde la que la traductora trabaja y desde la que puede ofrecer una resistencia emancipatoria enmarcada en un paradigma socio-crítico que la haga crecer personal y profesionalmente. La naturaleza compleja de la interacción humana y del mismo lenguaje, así 
como los procesos de creación y consolidación de la propia identidad llaman, y así lo pusieron de manifiesto las traductoras feministas del Quebec, a posturas críticas con el objetivo de subvertir no ya solo aquellas estructuras a nivel social y físico que oprimen a las identidades periféricas, sino también a nivel simbólico: transformar la sociedad palabra a palabra, texto a texto, discurso a discurso.

\subsection{Referencias bibliográficas}

Arrojo, R. (1994). Fidelity and The Gendered Translation. TTR: Traduction, Terminologie, Rédaction, 2, 147-163.

Bengoechea, M. (2015). Guía para la revisión del lenguaje desde la perspectiva de género. Diputación Foral de Bizkaia.

Bourdieu, P. (2000). La dominación masculina. Barcelona: Anagrama.

Brufau Alvira, N. (2008). Escollos de la traducción jurídica no sexista y su didáctica. En L. Pegenaute, J. De Cesaris, M. Tricás, y E. Bernal (Eds.), Actas del III Congreso Internacional de la Asociación Ibérica de Estudios de Traducción e Interpretación. La traducción del futuro: mediación lingüistica y cultural en el siglo XXI. Barcelona: PPU.

Brufau Alvira, N. (2009). Traducción y género: propuestas para nuevas éticas de la traducción en la era del feminismo transnacional (Tesis doctoral). Salamanca: Universidad de Salamanca.

Brufau Alvira, N. (2010). Las teorías feministas de la traducción a examen: Destilaciones para el siglo XXI. Granada: Comares.

Cabrera Infante, G. (1967). Tres tristes tigres. Barcelona: Seix Barral S.A.

Cabrera Infante, G. (2004). Three Trapped Tigers. Victoria: Dalkey Archive.

Casacuberta Nolla, F. y Peris Abril, Á. (2017). Traducción automática neuronal. Revista Tradumàtica. Número Revista Tradumàtica. Tecnologies de La Traducció, 15(15), 66-74. http://doi.org/10.5565/rev/tradumatica.203

Castro Váquez, O. (2008). Género y traducción: elementos discursivos para una reescritura feminista. Lectora, (14), 285-301.

Godard, B. (1990). Theorizing Feminist Discourse/Translation. En S. Basnett y A. Lefevere (Eds.), Translation. History and Culture (pp. 87-96). London: Frances Pinter.

Godayol Nogué, P. (2000). Espais de frontera: gènere i traducció. Vic: Eumo Editorial. Horkheimer, M. (1982). Critical Theory. New York: Continuum.

House, J., Martín Ruano, R. y Baumgarten, N. (2005). Translation and the Construction of Identity. Seoul: International Association for Translation and Intercultural Studies.

Levine, S. J. (1975). Writing as Translation: Three Trapped Tigers and a Cobra. Modern Language Notes, (2), 265-277. 
Levine, S. J. (1991). The Subversive Scribe: translating Latin American fiction. Saint Paul: Graywolf Press.

Lotbinière-Harwood, S. (1991). Re-Belle et Infidèle / The Body Bilingual. Toronto-Montréal: Women's Press / Les éditions du remue-ménage.

Martín Ruano, M. del R. (2006). Gramática, ideología y traducción: problemas de la transferencia asociados al género gramatical. En P. Elena García y J. de Kock (Eds.), Gramática y traducción (pp. 205-238). Universidad de Salamanca.

Martínez-Carrasco, R. y Frasquet, L. (2015). Traducció, identitat, subversió. Reflexions cap a una praxi queer de la traducció. Fòrum de Recerca, (20), 665-679.

Mills, S. (1995). Feminist Stylistics. New York \& London: Routledge.

Tymozcko, M. (2003). Ideology and the position of the translator: In what sense is translator 'in-between'? En M. Calzada Pérez (Ed.), Apropos of Ideology. Translation Studies on Ideology - Ideologies in Translation Studies (pp. 181-201). Manchester, UK: St. Jerome.

Tymozcko, M. (2006). Traducción, ética e ideología en la época de la globalización. Transfer, 1, 4-34.

Vidal Claramonte, Á. (2010). Traducción y asimetría. Frankfurt am Main: Peter Lang.

Von Flotow, L. (1999). Genders and the Translated Text: Developments in Transformance. Textus, 13, 275-87.

Von Flotow, L. (1991). Feminist Translation: Contexts, Practices and Theories. TTR: Traduction, Terminologie, Rédaction, 2, 69-84. 



\section{Parte II}

\section{Perspectivas didácticas,}

sanitarias y científico-tecnológicas 



\title{
Capítulo 5 \\ El cómic y el álbum ilustrado como recursos para la educación en la diversidad de género y afectivo-sexual
}

\author{
Andrés Giner Latorre \\ Profesor de Lengua castellana y Literatura \\ IES La Font de Sant Lluís (Valencia)
}

\subsection{Introducción}

El concepto de Alteridad de Simone de Beauvoir (2011/1949, págs. 47-64) explica que ninguna comunidad se define nunca como Una si no coloca inmediatamente a lo Otro enfrente de sí. La primera se define como lo esencial, lo Absoluto; mientras que el Otro es condenado a pasar por una situación de inferioridad, de opresión y a no compartir nunca el mundo por partes iguales. Entonces -y ahora- se trataba de más de la mitad de la humanidad. Más allá de una desigualdad entre sexos, existen más variables, más "otros" que se sitúan al margen de esa absoluta "normalidad". Basándonos en la perspectiva de los últimos estudios acerca de la interseccionalidad (Barrère Unzueta, 2010, 251; Platero, 2013, 176-177), nos referiremos a toda aquella diversidad afectivo-sexual y de género, aunque sabemos que trata también de abarcar un amplio abanico de diversidad entre las mujeres, como la raza, la etnia, la orientación sexual, la clase, la religión y otras "barreras" adicionales (Barrère Unzueta, págs. 245-246) que suponen en muchos casos una discriminación múltiple.

\subsection{La educación arcoíris ¿Un nuevo reto para la coeducación?}

En España no se puede hablar de coeducación -como hoy en día la conocemos- hasta 1990, con la elaboración de la LOGSE, que garantiza una igualdad "formal" (Subirats, 1994, 62) por incidir en el concepto de currículo oculto. Se enmarca en un período de sucesivas reformas para la eliminación de la discriminación formal y la lucha por una legislación más igualitaria. Para los estudios feministas el currículo oculto era relevante, porque es aquel sistema de valores que se transmite en la práctica escolar con carácter 
transversal. Este proceso funciona al tratarse todas las relaciones directas del triángulo de enseñanza-aprendizaje, entre las cuales Subirats (p. 63) destaca cinco temas para ana-lizar la incidencia del sexismo en la escuela:

- La posición de las mujeres como profesionales de la enseñanza, la jerarquía en los cargos, disciplinas o especialidades que se reducen a estereotipos y desigualdades.

- El androcentrismo científico y sus efectos sobre la educación, así como la ginopia o la ausencia sistematizada de las figuras femeninas.

- El androcentrismo lingüístico en la práctica docente en el aula y en el centro.

- Los manuales escolares y las lecturas infantiles y juveniles como materiales muy dados a la reproducción de roles o estereotipos de género.

- La interacción escolar, como suma de los anteriores, que exige al docente la tarea de localizar e intentar subsanar los sexismos de cualquier espacio educativo.

Sin embargo, en los últimos años el foco de estudio en coeducación se sitúa en otras variables del género y también vulnerable a una discriminación continuada, como son las personas lesbianas, gays, bisexuales, transexuales, transgénero, intersexuales y queers (LGTBIQ+). La base teórica de los estudios Queer, desarrollada a principios de los 90, afirma que las identidades sexuales y de género componen una "matriz heterosexual", siguiendo la terminología de Butler (Posada Kubissa, 2014, 149-150). Con ello, se naturaliza aquello que es producto de la clasificación cultural heterosexual, donde la dimensión del cuerpo sexual, roles sociales de género y el deseo están sujetos a una norma que exige que todos los sujetos se ajusten a ella. Pero, como se sabe, la diversidad es más amplia que esa "matriz" y esto supone un peligro para el orden heteropatriarcal.

A raíz de esto, «desnaturalizar la identidad sexual implica la renuncia a la reivindicación de la normalidad» (Córdoba, 2003, 87) para reivindicar otro lugar de enunciación, lo que se ha acuñado como teoría de la performatividad. Se insiste precisamente en la idea de construcción de un discurso para huir del naturalizador que nos ha llevado a la dominación heteropatriarcal (pág. 88.-89) y que obliga al individuo a situarse en el lugar asignado y a asumir unos significados sociales concretos asociados a este. Al individuo, con su identificación, se le exige un posicionamiento en las relaciones sociales (pág. 91). Pero esa "salida del armario" implica reconocerse con un estigma y asumir unos rasgos adscritos a la categoría no heterosexual desde los discursos sociales dominantes. La inevitable matriz acepta y comprende la existencia de un "otro" y este la asume como sujeto de vulnerabilidad (Butler, 2004, 52). La identidad no deja de ser interrogada y criticada por sus efectos excluyentes, porque es «amenazada por el exterior que ella misma constituye y está inevitablemente abierta a procesos de rearticulación y redefinición de sus límites» (Córdoba, pág. 94).

Si el sistema educativo en cuanto a microsociedad fomenta la reproducción cultural asumida como universal, el sistema sexo-género del Heteropatriarcado afecta a toda esta 
diversidad de la que hablamos. El reto de la coeducación en estos últimos años ha sido dar voz en las aulas (y en los centros) de toda la diversidad posible, cuestionar los fundamentos y desafiar unas verdades que han sido inculcadas como naturales. Castelar (2014, 83) incluso argumenta que se debe ir más allá y conocer la aportación de esta comunidad teniendo en cuenta su condición de vulnerabilidad humana, como ya exponía Butler.

Además, aunque el cambio cultural esperable en la educación se debe atender en todas las situaciones, el autor (pág. 84) incide especialmente en el lenguaje -heredado de la teoría performativa-, puesto que es por esta vía por donde opera la violencia. No solamente a través de un uso diferente de las palabras, sino de «la puesta en duda de los silencios, de aquello que no se habla» (pág. 84). Una educación inclusiva que lleve este tema al aula ofrece una posibilidad de abrirse al "otro" para reconocer la propia vulnerabilidad y la necesidad de construirse como sujeto a través del lenguaje (Butler, pág. 72).

Un texto como el de Subirats, de los años 90, sigue siendo preocupantemente vigente y podríamos tomar sus medidas de actuación para incluir a colectivos como el LGTBIQ+. Por tanto, en primer lugar, esa jerarquía haría referencia a tratar de evitar ocultar las diferentes identidades y expresiones de género u orientación afectivo-sexual tanto entre el alumnado como en el profesorado, sin que eso perjudique al individuo en el ámbito profesional o educativo. Por otro lado, es necesario recordar la trágica historia de estas personas durante siglos, como las persecuciones o las condenas (todavía existentes en algunos lugares del mundo) de cárcel, muerte..., pero también dar a conocer sus obras, logros, experiencias vitales y creaciones artísticas y culturales. Asimismo, debe estar presente esta diversidad en la educación sexual que reciban los y las adolescentes, puesto que es un tema de salud y recordemos que este es un derecho universal para toda la ciudadanía.

En cuanto al lenguaje, como generador de conciencia y atendiendo a la teoría performativa, en todo el centro educativo se debe garantizar la desaparición de prejuicios o estereotipos lingüísticos o etiquetas que discriminen o excluyan, e incluso algunos chistes o bromas inapropiadas. Además, términos como "tolerancia" o "normalizar", que hasta hace unos años se usaban fundamentalmente para la lucha por la igualdad en la educación, infieren, en realidad, que se pretende un reconocimiento igualitario con una identidad dominante (Platero, pág. 37), siendo esta última la "normalidad" (el patrón heteropatriarcal) y el resto de identidades, situadas al margen, "la diferencia". Ningún grupo social debe "tolerar" una identidad u orientación que ha estado presente desde el inicio de los tiempos, sino que se trata de visibilizar o celebrar y evitar así el rechazo continuado.

Por último, los materiales que manejamos a diario entre el profesorado necesitan proponer otras alternativas que refuercen estos valores. Un sencillo ejemplo puede ser integrar esta realidad en los enunciados de un problema de matemáticas o de una oración en lengua, puesto que configura la conciencia de la futura ciudadanía de nuestra sociedad. 
Afortunadamente, desde el ámbito legal valenciano, uno de los últimos logros para el reconocimiento de los derechos es la Ley 23/2018, de 29 de noviembre, de igualdad de las personas LGTBIQ+ en la Comunitat Valenciana. El capítulo 3, dedicado a la educación, incluye que el sistema educativo sea un espacio seguro y respetuoso, libre de toda discriminación y que garantice la igualdad en la diversidad. La Conselleria establece especificaciones de actuación en protocolos de prevención, acompañamiento e intervención en casos de LGTBIfobia. En este sentido, destaca la importancia que se le otorga a la inclusión en los currículos reglados y en la ordenación académica de contenidos relacionados con la diversidad de orientaciones, identidades y expresiones de género; del mismo modo, incluirlos de forma transversal en todas las asignaturas. Así pues, resulta evidente que se integre en todas las estrategias pedagógicas, más allá de los planes de igualdad, convivencia o acción tutorial para garantizar la igualdad en la diversidad y la no discriminación hacia las personas LGTBIQ+, además de las medidas preventivas de violencia u odio hacia ellas.

Es necesario el amparo legal por la realidad que sufren estas personas al no ajustarse a la masculinidad hegemónica heteronormativa, especialmente la población joven, la más vulnerable. Aprenden (y asumen) comportamientos relacionados con una orientación heterosexual, que se caracteriza por las expectativas de la sociedad y que puede desembocar en una angustia capaz de generar miedo, trastornos de depresión, ansiedad, autorrechazo, culpabilidad, impotencia o soledad, entre otras, como recogieron FELGTB y COGAM en su estudio ${ }^{7}$ de 2012 (págs. 43-49). Se considera, por tanto, violencia sistémica y, como es sabido, puede desencadenar en formas más explícitas, como la agresión física, que últimamente sufren algunas personas transgénero en las redes sociales; o el suicidio en adolescentes.

El bullying homofóbico y transfóbico conviene tratarse en un contexto amplio, transversal y no solamente en actividades específicas propias de la acción tutorial (Martxueta Pérez \& Etxeberria Murgiondo, 2014,125-126), como aquellas de conmemoración de ciertos días. Se trata de crear oportunidades para que el alumnado aumente sus conocimientos y, a su vez, piense, reflexione y conforme una opinión o actitud crítica acerca de las consecuencias del prejuicio y la discriminación. Los materiales de aprendizaje que se empleen tienen que estar al alcance de cualquier miembro de la comunidad educativa, como la biblioteca o el rincón de lectura, y en ellos se deben especificar cuestiones LGT$\mathrm{BIQ}+$ sin caer en el estereotipo con relación al sexo y al género.

En cierto sentido, se exige un cambio de visión en todos los estratos del sistema educativo, pero especialmente en el profesorado, con el objetivo de reflexionar sobre la práctica en su aula. Barbé i Serra y otros (2014, 46-51), por ejemplo, recomiendan la necesidad de fomentar la provención, esto es, desarrollar recursos, estrategias y habilidades para afrontar los conflictos antes de que llegue la situación de crisis. Para ello, se requiere del enfoque socioafectivo y sociocrítico en las actividades y no tanto del aprendizaje

7El estudio recoge los datos de alumnado homosexual y bisexual cisgénero, no se incluye la orientación asexual/arromántica ni las identidades transgénero ni género fluido. 
cognitivo-intelectual. Además, el proceso artístico es un buen motor del cambio, pueden desarrollarse las habilidades de empatía y detección de injusticias y desigualdades. Se trata de hacer una lectura crítica de nuestro entorno y aprender a desobedecer ciertos patrones, argumentando por qué se desobedece y planteando alternativas.

\subsection{La educación lectoliteraria como recurso para la igualdad}

El fomento lector, como prioridad de cualquier centro educativo y elemento transversal para cualquier curso y asignatura, pretende consolidar la formación del alumnado como lector-receptor autónomo y capacitado para la recepción personal, valorativa y crítica de cualquier producción escrita (Mendoza, 2004, 35). La lectura es una aliada en la educación de todas las diversidades por su carácter integrador e interdisciplinar en las cuatro dimensiones que propone Ballester $(2015,134)$, entre la que destacamos la ética, puesto que es capaz de proyectar los valores de una sociedad e incitar a la reflexión para el desarrollo del espíritu crítico.

En la sociedad actual, marcada por la diversidad y una pluralidad de voces, también conviene trasladar al aula ese deseo de generar un canon literario flexible y plural en tipologías, métodos, lenguajes, etc. y desobedecer al tradicional listado que nos ha ido domesticando y limitando a la elección de ciertas lecturas. Mendoza (pág. 126), por ejemplo, alude a las relegaciones, marginaciones u olvidos que sufren ciertos temas, personajes o sobre todo autoría, pero reivindica la creación de una renovación de la educación literaria en cuanto a su tratamiento. Una metodología más ecléctica, interdisciplinar e intercultural en el desarrollo de la competencia literaria, que se aleje del cumplimiento tradicional del Currículum (Ballester \& Ibarra, 2003, 12). "La lectura nos engendra. Todo lo que se lee es íntimamente forjado. Una persona cuando lee se lee" (pág. 16). En este sentido, encontraríamos el espacio idóneo para que el alumnado queer pudiera identificarse con los argumentos o los personajes, para visibilizar y conseguir también la no discriminación del resto.

\subsection{Viñetas para una educación inclusiva}

El éxito del cómic en los últimos años ha permitido que llegue a las aulas como recurso para el fomento lector y el desarrollo de la competencia lecto-literaria, entre otras, gracias a su formato basado en un lenguaje verbo-icónico. Aunque Altarriba $(2003,8)$ reivindique la necesidad de considerarlo independiente a la historieta, lejos de incluirse como género literario, su utilización didáctica coincide con la literatura por facilitar los análisis simbólicos, estructurales o sociológicos que se requieren en el aula para la educación en valores.

En nuestra propuesta hemos buscado tanto cómics como álbumes ilustrados sobre temas de diversidad de género y afectivo-sexual. La causa principal es que la actividad gráfica estimula el pensamiento multisensorial y desarrolla en el individuo destrezas metacognitivas, como la capacidad de observar y reflexionar sobre los propios pensamientos 
(Bowkett \& Hitchman, pág. 103). Entre los beneficios para adquirir una competencia comunicativa -la finalidad de la educación lingüística y literaria- se encuentra el enriquecimiento del vocabulario de la emoción, la importancia de la descripción de personajes y el uso de verbos y adverbios para refinar el diálogo. Del mismo modo, entre las destrezas que se desarrollan mediante el uso de imágenes visuales, destacan la observación o atención, asimilación de información visual y el aumento de la experiencia del pensamiento inferencial o la especulación, entre otras (Bowkett \& Hitchman, pág. 193). Pero sobre todo, con estas modalidades sensoriales y la interrelación de impresiones podemos llegar al objetivo que perseguimos en este trabajo: aumentar la capacidad de empatizar.

A propósito de la reflexión sobre los códigos de este formato, la importancia de leer cómics estriba en la intención comunicativa que suscitan las viñetas o ilustraciones que acompañan el texto. Esto genera un impacto en el/la lector/a por suscitar de este enfoque pragmático las dimensiones de la personalidad (Guzmán López, 2011, 126-129), esto es, en los cómics los personajes hablan (expresión lingüística), se mueven (dinámica), gesticulan (dramática), se relacionan (social), se ubican en un contexto (natural), etc. Además, como género narrativo o secuencial, permite situar a todo el alumnado en un espacio común, con una referencia compartida y de rápida identificación con todos los elementos de la lectura.

Por último, no se puede dejar de lado la importancia de toda la información insinuada que nos sugiere la historia para situar al/a la lector/a en un hecho concreto "que atrape", que le propicie una respuesta (Colomer, 2002, 117). En este sentido, nos referimos a la empatía afectiva unida al reto intelectual, es decir, se adquieren conocimientos o formas nuevas experimentales sin desdeñar el disfrute estético. Esto se refuerza en obras de la temática que tratamos, porque el aspecto visual suscita una potencia sensitiva que, acompa-ñada de las fórmulas textuales, puede llegar a buscar la forma de pulsar distintas fibras emocionales (pág. 90).

\subsection{Biblioteca de colores: nuestra propuesta}

Para la selección de nuestros materiales en todas las etapas educativas, hemos tenido en cuenta la relación de las lecturas apropiadas para el curso con los diferentes estadios psicológicos de cada franja etaria, teniendo a Cerrillo ${ }^{8}$ (2007, 98-111) como referencia. Así pues, en Infantil (de 3 a 6 años) se debe atender a contenidos familiares del entorno del niño/a, sencillez expresiva y escasa carga conceptual, pero sobre todo un diseño de gran formato, muchas ilustraciones a todo color y letra grande. Como a partir de los 5 años el alumnado ya es consciente de los roles de género y los reproduce, desde el principio de la escolaridad se debe focalizar en romper las diferencias de roles en colores, ropa, juguetes, labores cotidianas y preferencias, así como la diversidad familiar (Sánchez Sáinz, 2013, 55-57).

8 No obstante, su objeto de estudio es la Literatura infantil y juvenil, pero los criterios son muy similares. 
El siguiente estadio permite incluir el humor en historias de elementos sorprendentes, de exposición clara y desenlace rápido pero sin perder la estructura literaria tradicional, con una composición de página de imágenes grandes. Cabe evitar los objetos de burla que puedan derivar en un posible acoso escolar o bullying. Para ello, Sánchez Sáinz (57-75) recomienda introducir de forma progresiva la terminología y definición de las identidades, orientaciones, etc., pero incide especialmente en la apariencia física (expresión de género) y en comportamientos o roles que se adquieren para evitar situaciones como la vigilancia de género. Durante toda la Primaria debe reforzarse y profundizarse en el tema de forma pareja al cambio de formato de los últimos años (9-11 años), con composiciones de páginas más complejas, tipografía normalizada y más extensas, llegando al formato convencional de novela gráfica.

El quinto estadio (12-14 años) de Cerrillo se enmarca en los primeros años de la secundaria, caracterizado por abrir el abanico de posibilidades en el contenido de las obras, estructura con exposiciones detalladas y descripciones extensas, con final feliz o, al menos, dando respuesta a los problemas planteados. Se resuelve con el estadio definitivo (a partir de 15 años), de maduración y acceso pleno a la lectura, con un diseño similar al de las obras de adultos. Precisamente, la temática debe ayudar a conocer el mundo de los demás, a formarse en el conjunto de la vida y a plantearse problemas y responsabilidades sociales. Por ello, los profesores Pichardo \& De Stéfano $(2013,76-97)$ tratan plenamente la cuestión LGTBIfóbica desde el lenguaje hasta las actitudes, motivos de insulto y exclusión, las medidas para cambiar o evitar las situaciones de acoso, etc. En el último estadio se supone que se comienza a desarrollar la conciencia crítica a través de la reflexión de las obras, por eso es necesario que el proceso de concienciación sea urgente hacia esta diversidad.

La selección de las 22 obras reúne dos condiciones fundamentales: la temática LGTBIQ+ de forma explícita o como subtexto detectable en la diversidad de género u orientación afectivo-sexual; y el formato cómic o el álbum ilustrado. Hemos agrupado las obras en cinco bloques temáticos, los más presentes en cada obra, pero esto no significa que no se interrelacionen diversos temas de otros bloques de clasificación. Con estos ejemplares se pretende ofrecer al profesorado un abanico de posibilidades o finalidades en el tratamiento de la lectura en el aula: desde la denuncia o concienciación y compromiso hasta la divulgación, la recreación y/o presentación de forma natural, sin incidir necesariamente en caracterizar la identificación de género. Además, se ha tenido en cuenta el currículum de cada etapa educativa para una posible aplicación, ya sea como contenido o apoyo de este.

\subsection{1. "Salida del armario"/ definición de la identidad}

Las historias en este primer eje temático de "Salida del armario" o definición de la identidad son explícitas, ya sea la identificación o descubrimiento de una identidad u orientación como las primeras experiencias amorosas y sexuales. En algunas se incide en los sentimientos -normalmente dolorosos-; mientras que en otras presentan un proceso de resiliencia, de superación o de aceptación progresiva por la sociedad. Esta selección 
ahonda la homosexualidad, la bisexualidad, la asexualidad, la transexualidad/disforia de género o identidad transgénero; así como la relación de estas con la variable cultural y racial en algunos casos. Los personajes principales de estas obras coinciden con la edad del alumnado a quienes van dirigidos: la niñez y la adolescencia. Por eso se trata del listado más extenso, puesto que es quizás la selección más fácilmente adaptable al aula.

Tabla 1.1. Bloque temático 1: "Salida del armario"

\begin{tabular}{|c|c|c|c|}
\hline $\begin{array}{l}\text { Subtemas o } \\
\text { subgéneros }\end{array}$ & Obra & $\begin{array}{c}\text { Curso/etapa } \\
\text { educativa }\end{array}$ & Recomendaciones/aplicaciones \\
\hline $\begin{array}{l}\text { Transgénero } \\
\text { Expresión de } \\
\text { género } \\
\text { Identidad personal } \\
\text { Inclusión social } \\
\text { Amistad }\end{array}$ & $\begin{array}{l}\text { Ahora me llamo } \\
\text { Luisa (2017. } \\
\text { Algar), de Jessica } \\
\text { Walton y Doygal } \\
\text { MacPherson. }\end{array}$ & $\begin{array}{l}\text { Infantil (3-5 } \\
\text { años) }\end{array}$ & $\begin{array}{l}\text { Álbum ilustrado que entronca con el } \\
\text { bloque del conocimiento de sí mismo } \\
\text { y autonomía personal. Se promueve } \\
\text { la vida en sociedad, que muchos } \\
\text { maestros y maestras enseñan con } \\
\text { la lectura en voz alta de diferentes } \\
\text { cuentos. }\end{array}$ \\
\hline $\begin{array}{l}\text { Homosexualidad } \\
\text { masculina } \\
\text { Diversidad } \\
\text { cultural } \\
\text { Aceptación } \\
\text { Familia }\end{array}$ & $\begin{array}{l}\text { El marido de } \\
\text { mi hermano } \\
\text { (2019. Panini } \\
\text { Comics), vols. 1 } \\
\text { y 2, de Gengoroh } \\
\text { Tagame. }\end{array}$ & \begin{tabular}{|l} 
3er ciclo de \\
Primaria/ \\
1er ciclo de \\
Secundaria
\end{tabular} & $\begin{array}{l}\text { Manga sobre el choque cultural } \\
\text { (Canadá-Japón) y superación de } \\
\text { prejuicios.Paraasentarconocimientos } \\
\text { sobre diversidad familiar (Ciencias } \\
\text { Sociales, en Primaria) o convivencia } \\
\text { y ciudadanía y diálogo entre culturas } \\
\text { (Valores Éticos, ESO). }\end{array}$ \\
\hline $\begin{array}{l}\text { Transgénero } \\
\text { Disforia de } \\
\text { género } \\
\text { Reasignación de } \\
\text { género FtM } \\
\text { Adolescencia }\end{array}$ & $\begin{array}{l}\text { Llamadme } \\
\text { Nathan }(2019 . \\
\text { Astiberri), } \\
\text { de Catherine } \\
\text { Castro y Quentin } \\
\text { Zuttion. }\end{array}$ & $3^{\circ} / 4^{\circ}$ de ESO & $\begin{array}{l}\text { Cómic sobre una historia real acerca } \\
\text { del proceso de reasignación de } \\
\text { género desde el descubrimiento y } \\
\text { redefinición hasta las intervenciones } \\
\text { médicas. El tema puede tratarse en } \\
\text { las asignatura de Biología y Geología } \\
\text { (personas y salud), con contenidos } \\
\text { como sexualidad, cambios físicos y } \\
\text { psíquicos. }\end{array}$ \\
\hline $\begin{array}{l}\text { Identidad personal } \\
\text { Homosexualidad } \\
\text { femenina } \\
\text { Adolescencia } \\
\text { Deporte }\end{array}$ & $\begin{array}{l}\text { Piruetas (2019. } \\
\text { La Cúpula), de } \\
\text { Tillie Walden. }\end{array}$ & 1er ciclo de ESO & $\begin{array}{l}\text { Novela gráfica de trasfondo } \\
\text { deportivo para trabajar en Educación } \\
\text { Física (bloque Juegos y Deportes), } \\
\text { con valores como el esfuerzo y } \\
\text { la perseverancia, los sueños, las } \\
\text { decisiones... }\end{array}$ \\
\hline
\end{tabular}




\begin{tabular}{|c|c|c|c|}
\hline $\begin{array}{l}\text { Subtemas o } \\
\text { subgéneros }\end{array}$ & Obra & $\begin{array}{c}\text { Curso/etapa } \\
\text { educativa }\end{array}$ & Recomendaciones/aplicaciones \\
\hline $\begin{array}{l}\text { Diversidad racial } \\
\text { Bisexualidad } \\
\text { Adolescencia }\end{array}$ & $\begin{array}{l}\text { Bi-assed (2016-), } \\
\text { de Olivia Dinnall. }\end{array}$ & $2^{\circ}$ ciclo de ESO & $\begin{array}{l}\text { Webcomic accesible al aula para } \\
\text { tratar la diversidad múltiple y } \\
\text { transversalidad y evitar el acoso } \\
\text { escolar o bullying a la diferencia } \\
\text { en los institutos. Son páginas breves } \\
\text { e independientes, adaptables en } \\
\text { cualquier actividad. Disponible en } \\
\text { inglés. }\end{array}$ \\
\hline $\begin{array}{l}\text { Identidad trans } \\
\text { Orientación } \\
\text { afectivo-sexual } \\
\text { Amor }\end{array}$ & $\begin{array}{l}\text { Transito (2015), } \\
\text { de David Cantero } \\
\text { e Ian Bermúdez } \\
\text { Raventós. } \\
\text { Bellaterra }\end{array}$ & $\begin{array}{l}4^{\circ} \text { de } \mathrm{ESO} / 1^{\circ} \text { de } \\
\text { Bachillerato }\end{array}$ & $\begin{array}{l}\text { El concepto de identidad de género } \\
\text { abordado desde Valores Éticos } \\
\text { o Filosofía se puede aplicar al } \\
\text { descubrimiento de la protagonista, } \\
\text { que experimenta un aprendizaje de } \\
\text { las diferentes realidades existentes } \\
\text { y las posibilidades múltiples de las } \\
\text { variables identidad-sexo-género. }\end{array}$ \\
\hline $\begin{array}{l}\text { Transexualidad } \\
\text { Disforia de } \\
\text { género } \\
\text { Crisis de } \\
\text { identidad }\end{array}$ & $\begin{array}{l}\text { Justine (2014), } \\
\text { de Gauthier. } \\
\text { Diminuta }\end{array}$ & $2^{\circ}$ ciclo de ESO & $\begin{array}{l}\text { Formato muy breve, muestra una } \\
\text { realidad muy cruday puede emplearse } \\
\text { con el objetivo de empatizar con el } \\
\text { proceso de muchas personas trans y } \\
\text { reflexionar desde la Filosofía en la } \\
\text { construcción personal (identidad y } \\
\text { género) o la socialización (los otros: } \\
\text { la intersubjetividad). }\end{array}$ \\
\hline
\end{tabular}

\subsubsection{Ruptura de estereotipos tradicionales}

Las únicas muestras clasificadas de ruptura de estereotipos tradicionales presentan los patrones tradicionales revertidos, para ofrecer así una lectura más amplia de las posibilidades en nuestra sociedad. Rompen el estereotipo o incluyen una perspectiva diferente. En este caso se tratan los estereotipos por apariencia física, roles de género o lesbianismo/bisexualidad. 
Tabla 1.2. Bloque temático 2. Ruptura de estereotipos

\begin{tabular}{|c|c|c|c|}
\hline $\begin{array}{l}\text { Subtemas o } \\
\text { subgéneros }\end{array}$ & Obra & $\begin{array}{c}\text { Curso/etapa } \\
\text { educativa }\end{array}$ & Recomendaciones/ aplicaciones \\
\hline $\begin{array}{l}\text { Amor y amistad } \\
\text { Homosexualidad } \\
\text { femenina } \\
\text { Roles de género } \\
\text { Expresión de } \\
\text { género }\end{array}$ & $\begin{array}{l}\text { Érase una vez dos } \\
\text { princesas (2019. } \\
\text { La Cúpula), de } \\
\text { Katie O'Neill. }\end{array}$ & \begin{tabular}{|l} 
3er ciclo \\
Primaria/ \\
1er ciclo de \\
Secundaria
\end{tabular} & $\begin{array}{l}\text { Revierte la perspectiva de género } \\
\text { de las funciones del cuento } \\
\text { tradicional, con un cambio en el } \\
\text { comportamiento y características } \\
\text { de los actantes (por sexualidad, } \\
\text { raza, clase...). Puede ser el material } \\
\text { de partida para los géneros literarios } \\
\text { (bloque de "educación literaria" en } \\
\text { Lengua). }\end{array}$ \\
\hline $\begin{array}{l}\text { Feminismo } \\
\text { Injusticia social } \\
\text { Historia de las } \\
\text { mujeres } \\
\text { Orientación } \\
\text { afectivo-sexual }\end{array}$ & $\begin{array}{l}\text { Las cien noches } \\
\text { de Hero ( } 2017 . \\
\text { Impedimenta), de } \\
\text { Isabel Greenberg. }\end{array}$ & $2^{\circ} / 3^{\circ}$ de la $\mathrm{ESO}$ & $\begin{array}{l}\text { Como el caso anterior, al tratarse } \\
\text { de una relectura de Las mil y una } \\
\text { noches, se puede dar énfasis al } \\
\text { papel de las mujeres en la historia, } \\
\text { la condición social de estas y } \\
\text { revertir ciertas situaciones que } \\
\text { nos muestra el folklore o ciertas } \\
\text { tradiciones narrativas. }\end{array}$ \\
\hline
\end{tabular}

\subsubsection{La diversidad de género de forma subtextual o cuqui-queer}

La diversidad de género de forma subtextual o cuqui-queer es muy común entre los webcomics, pero también presentes en papel. Destaca, dentro de esta temática, la cuquiqueer, que se puede definir como una estrategia expresiva de formas romas, estilo cartoon (con la serie televisiva Hora de aventuras como modelo) y tonalidades amables y estética con colores vivos (Hidalgo \& McCausland, 2018). Como subtexto a este elemento fantástico se encuentra la reflexión-sin evitar el trauma- que exploran las orientaciones e identidades no normativas, aunque no son expuestas de forma explícita. En el caso de los álbumes ilustrados no se sigue esta estética, pero observamos la apuesta por presentar el tema de la búsqueda o construcción de la identidad (sin necesidad de explicitar el sistema sexo/género u otras identidades). Tanto un formato como el otro son idóneos para las primeras etapas escolares, al incidir especialmente en el respeto de la diversidad y la inclusión. 
Tabla 1.3. Bloque temático 3. Diversidad de género (subtextual)

\begin{tabular}{|c|c|c|c|}
\hline $\begin{array}{l}\text { Subtemas o } \\
\text { subgéneros }\end{array}$ & Obra & $\begin{array}{c}\text { Curso/etapa } \\
\text { educativa }\end{array}$ & Recomendaciones/ aplicaciones \\
\hline $\begin{array}{l}\text { Búsqueda de } \\
\text { identidad } \\
\text { Aceptación social } \\
\text { Familia y entorno }\end{array}$ & $\begin{array}{l}\text { Rojo. Historia } \\
\text { de una cera de } \\
\text { colores }(2017 . \\
\text { Takatuka), de } \\
\text { Michel Hall. }\end{array}$ & Infantil & $\begin{array}{l}\text { Puede presentarse como la búsqueda } \\
\text { de la identidad, rehuyendo de los roles } \\
\text { de género en la sociedad. La cera de } \\
\text { color "rojo" actúa como metáfora } \\
\text { de personas no identificadas con la } \\
\text { identidad asignada al nacer y la carga } \\
\text { que supone llevar una "etiqueta". }\end{array}$ \\
\hline $\begin{array}{l}\text { Identidad } \\
\text { Aceptación social } \\
\text { Respeto } \\
\text { Familia }\end{array}$ & $\begin{array}{l}\text { Ni guau ni } \\
\text { miau (2019. } \\
\text { NubeOcho), de } \\
\text { Blanca Lacasa y } \\
\text { Gómez. }\end{array}$ & Infantil & $\begin{array}{l}\text { Abordado con protagonistas } \\
\text { animales humanizados en contextos } \\
\text { cotidianos, como estrategia literaria } \\
\text { que facilita el tratamiento de la } \\
\text { redefinición del individuo. }\end{array}$ \\
\hline $\begin{array}{l}\text { Fantasía } \\
\text { Roles de género } \\
\text { Amistad } \\
\text { Respeto por el } \\
\text { medio }\end{array}$ & $\begin{array}{l}\text { La sociedad de } \\
\text { los Dragones } \\
\text { de Té (2020. La } \\
\text { Cúpula), de Katie } \\
\text { O’Neill. }\end{array}$ & $\begin{array}{l}\text { Primer ciclo de } \\
\text { Primaria }\end{array}$ & $\begin{array}{l}\text { La forma en la que se propone la } \\
\text { diversidad de muchas identidades y } \\
\text { la ruptura de los roles sociales (en } \\
\text { clave metafórica) encaja fácilmente } \\
\text { en el tratamiento de los seres vivos, } \\
\text { la observación científica del medio... } \\
\text { (Ciencias Naturales), bien para } \\
\text { comparar o desmentir. }\end{array}$ \\
\hline $\begin{array}{l}\text { Fantasía } \\
\text { Roles de género } \\
\text { Prejuicios sociales } \\
\text { Familia }\end{array}$ & $\begin{array}{l}\text { El niño } \\
\text { brujo (2018. } \\
\text { HarperCollins), } \\
\text { de Molly Knox } \\
\text { Oestertag. }\end{array}$ & $\begin{array}{l}\text { Toda Primaria } \\
\text { (recomendamos } \\
2^{\circ} \text { ciclo) }\end{array}$ & $\begin{array}{l}\text { Como proyecto entre Sociales y } \\
\text { Naturales por la estructura social } \\
\text { binaria que presenta la familia en } \\
\text { el libro y en la que no encaja el } \\
\text { protagonista, por un lado; pero } \\
\text { también la presencia de conjuros, } \\
\text { símbolos y alquimia para comparar } \\
\text { con la experimentación científica. }\end{array}$ \\
\hline $\begin{array}{l}\text { Misterio } \\
\text { Aventuras } \\
\text { Humor } \\
\text { Estereotipos de } \\
\text { belleza } \\
\text { Roles de género } \\
\text { Adolescencia }\end{array}$ & $\begin{array}{l}\text { Leñadoras. } \\
\text { Cuidado con el } \\
\text { gatete sagrado } \\
\text { (2016. Sapristi, } \\
4 \text { vols.), de N. } \\
\text { Stevenson, G. } \\
\text { Ellis, S. Watters } \\
\text { y B. Allen. }\end{array}$ & $\begin{array}{l}\text { 3er ciclo de } \\
\text { Primaria/ } \\
\text { 1er ciclo de } \\
\text { Secundaria }\end{array}$ & $\begin{array}{l}\text { Como lectura interdisciplinar } \\
\text { del curso: aspectos de la vida y } \\
\text { exploración natural (botánica, } \\
\text { zoología, astronomía); historia } \\
\text { (civilizaciones antiguas) y el } \\
\text { misterio, aventuras y jerga juvenil } \\
\text { (como criterio de selección en la } \\
\text { lectura de la asignatura de Lengua y } \\
\text { Literatura). }\end{array}$ \\
\hline
\end{tabular}




\begin{tabular}{|c|c|c|c|}
\hline $\begin{array}{l}\text { Subtemas o } \\
\text { subgéneros }\end{array}$ & Obra & $\begin{array}{c}\text { Curso/etapa } \\
\text { educativa }\end{array}$ & Recomendaciones/ aplicaciones \\
\hline $\begin{array}{l}\text { Fantasía } \\
\text { Aventuras } \\
\text { Humor } \\
\text { Familia } \\
\text { Diversidad de } \\
\text { género }\end{array}$ & $\begin{array}{l}\text { Travelogue } \\
\text { (2014-), de } \\
\text { Aatmaja Pandya }\end{array}$ & $\begin{array}{l}\text { 3er ciclo de } \\
\text { primaria/ } \\
\text { 1er ciclo de } \\
\text { secundaria }\end{array}$ & $\begin{array}{l}\text { Webcomic accesible donde se } \\
\text { contempla la diversidad familiar y de } \\
\text { orientación afectivo-sexual, incluida } \\
\text { la asexual/arromántica. Para trabajar } \\
\text { de forma independiente, reforzar la } \\
\text { comprensión lectora o familiarizarse } \\
\text { con el lenguaje del cómic, presente en } \\
\text { el Currículum de Lengua y Literatura } \\
\text { de ambas etapas. }\end{array}$ \\
\hline
\end{tabular}

\subsubsection{Expresión de género}

Las obras relacionadas con la expresión de género se recomiendan para infantil y primaria por mostrar una superación del estereotipo de género relacionado con la apariencia física. Son muestras muy sencillas a veces, como los colores, la vestimenta o las aficio-nes de una persona, pero pueden desencadenar en burla o rechazo. Afortunadamente, todos tienen un final feliz.

Tabla 1.4. Bloque temático 4. Expresión de género

\begin{tabular}{|c|c|c|c|}
\hline $\begin{array}{l}\text { Subtemas o } \\
\text { subgéneros }\end{array}$ & Obra & $\begin{array}{c}\text { Curso/etapa } \\
\text { educativa }\end{array}$ & Recomendaciones/aplicaciones \\
\hline $\begin{array}{l}\text { Vigilancia de } \\
\text { género } \\
\text { Familia y amistad } \\
\text { Inclusión }\end{array}$ & $\begin{array}{l}\text { ¡Vivan las uñas } \\
\text { de colores! (2020. } \\
\text { NubeOcho), de } \\
\text { Alicia Acosta, } \\
\text { Luis Amavisca y } \\
\text { Gusti. }\end{array}$ & $\begin{array}{l}\text { Infantil (muy } \\
\text { recomendable } \\
\text { para } 5 \text { años) }\end{array}$ & $\begin{array}{l}\text { Para evitar que caigan en el binomio } \\
\text { de género y promover la aceptación } \\
\text { al grupo de cualquier apariencia } \\
\text { física (expresión de género) y } \\
\text { la libertad de expresar nuestros } \\
\text { gustos (color, juguetes, ciertas } \\
\text { acciones/ estética...), sin caer en los } \\
\text { estereotipos. }\end{array}$ \\
\hline $\begin{array}{l}\text { Vigilancia de } \\
\text { género } \\
\text { Inclusión } \\
\text { Amistad }\end{array}$ & \begin{tabular}{|l|} 
Princesa \\
Kevin (2019. \\
Edelvives), de \\
Michaël Escoffier \\
y Roland \\
Garrigue.
\end{tabular} & $\begin{array}{l}\text { Primer ciclo de } \\
\text { primaria }\end{array}$ & $\begin{array}{l}\text { Tanto el bloque de Valores Sociales } \\
\text { y Cívicos, dedicados a la identidad } \\
\text { de la persona, como en el bloque } \\
\text { de Ciencias Sociales, que incluye } \\
\text { evitar estereotipos sexistas, se } \\
\text { puede abordar esta historia. Se trata } \\
\text { de recordar los inconvenientes de } \\
\text { la asignación social de prendas de } \\
\text { vestir. }\end{array}$ \\
\hline
\end{tabular}




\begin{tabular}{|l|l|l|l|}
\hline \multicolumn{1}{|c|}{$\begin{array}{c}\text { Subtemas o } \\
\text { subgéneros }\end{array}$} & \multicolumn{1}{|c|}{ Obra } & $\begin{array}{c}\text { Curso/etapa } \\
\text { educativa }\end{array}$ & Recomendaciones/ aplicaciones \\
\hline $\begin{array}{l}\text { Moda } \\
\text { Identidad } \\
\text { Prejuicios } \\
\text { sociales } \\
\text { Amor }\end{array}$ & $\begin{array}{l}\text { El príncipe y la } \\
\text { modista (2019. } \\
\text { Sapristi), de Jen }\end{array}$ & $\begin{array}{l}\text { Último ciclo de } \\
\text { primaria }\end{array}$ & $\begin{array}{l}\text { Con una exigencia de lectura mayor, } \\
\text { Sang enmarca en la Francia del XVII, } \\
\text { idóneo para el bloque de Historia en } \\
\text { Ciencias Sociales. Plantea el miedo } \\
\text { de revelar la doble identidad con } \\
\text { la apariencia que decide mostrar } \\
\text { cada noche el protagonista, sin caer } \\
\text { en los estereotipos de género o de } \\
\text { orientación sexual. }\end{array}$ \\
\hline
\end{tabular}

\subsubsection{Contexto histórico-social}

Las obras relacionadas con el contexto histórico-social son quizás la mejor opción para los últimos cursos de Secundaria o Bachillerato por la reflexión acerca de la historia social de las personas LGTBIQ+. Además, se suma la complejidad o dureza del lenguaje en algunos casos, así como ciertas escenas que podrían resultar muy impactantes en una franja menor de edad.

Tabla 1.5. Bloque temático 5. Contexto histórico-social

\begin{tabular}{|c|c|c|c|}
\hline $\begin{array}{l}\text { Subtemas o } \\
\text { subgéneros }\end{array}$ & Obra & $\begin{array}{c}\text { Curso/etapa } \\
\text { educativa }\end{array}$ & Recomendaciones/aplicaciones \\
\hline $\begin{array}{l}\text { Franquismo } \\
\text { Persecución } \\
\text { Homosexualidad } \\
\text { Crisis de } \\
\text { identidad }\end{array}$ & $\begin{array}{l}\text { El violeta }(2018 . \\
\text { Drakul), de } \\
\text { Marina Cochet, } \\
\text { Juan Sepúlveda } \\
\text { Sanchis y } \\
\text { Antonio Santos } \\
\text { Mercero. }\end{array}$ & Bachillerato & $\begin{array}{l}\text { Enmarcado en el periodo } \\
\text { impartido en Historia de España } \\
\left(2^{\circ}\right) \text {. Dos experiencias paralelas } \\
\text { e interrelacionadas que explican } \\
\text { cuáles eran las dos opciones como } \\
\text { homosexual en la España de Franco. } \\
\text { Recurso para visibilizar un grupo } \\
\text { muy perseguido por el régimen y } \\
\text { hasta ahora bastante silenciado. }\end{array}$ \\
\hline $\begin{array}{l}\text { Historia } \\
\text { contemporánea } \\
\text { Crisis de } \\
\text { identidad } \\
\text { Expresión de } \\
\text { género } \\
\text { Relaciones } \\
\text { sexuales }\end{array}$ & $\begin{array}{l}\text { Degenerado } \\
\text { (2014. Dibbuks), } \\
\text { de Chloé } \\
\text { Cruchaudet. }\end{array}$ & Bachillerato & $\begin{array}{l}\text { Escenas muy explícitas en materia } \\
\text { sexual, pero aborda la historia } \\
\text { real de una crisis de identidad tras } \\
\text { participar en la Primera Guerra } \\
\text { Mundial. Debe primar la reflexión } \\
\text { del estado psíquico del protagonista } \\
\text { y su evolución a partir de las } \\
\text { consecuencias del conflicto. }\end{array}$ \\
\hline
\end{tabular}




\begin{tabular}{|c|c|c|c|}
\hline $\begin{array}{l}\text { Subtemas o } \\
\text { subgéneros }\end{array}$ & Obra & $\begin{array}{c}\text { Curso/etapa } \\
\text { educativa }\end{array}$ & Recomendaciones/aplicaciones \\
\hline $\begin{array}{l}\text { Historia } \\
\text { contemporánea } \\
\text { Activismo } \\
\text { Persecución } \\
\text { Identidad }\end{array}$ & $\begin{array}{l}\text { Stuck rubber } \\
\text { baby. Mundos } \\
\text { diferentes } \\
(2016 / 1995 . \\
\text { Astiberri), de } \\
\text { Howard Cruse. }\end{array}$ & $\begin{array}{l}4^{\circ} \mathrm{ESO} / \\
\text { Bachillerato }\end{array}$ & $\begin{array}{l}\text { Un fragmento de la historia de los } \\
\text { Estados Unidos más activa en la } \\
\text { lucha por los derechos civiles: los } \\
\text { años } 60 \text { y } 70 \text {. De forma transversal } \\
\text { trata la sexualidad, la raza y otros } \\
\text { colectivos oprimidos en la época. } \\
\text { Aplicable a la asignatura de Historia } \\
\text { del mundo contemporáneo. }\end{array}$ \\
\hline $\begin{array}{l}\text { Arte } \\
\text { contemporáneo } \\
\text { Expresión de } \\
\text { género } \\
\text { Identidad } \\
\text { Bisexualidad }\end{array}$ & $\begin{array}{l}\text { Tamara de } \\
\text { Lempicka (2019. } \\
\text { Planeta), de } \\
\text { Virginie Greiner } \\
\text { y Daphné } \\
\text { Tamara. }\end{array}$ & $\begin{array}{l}4^{\circ} \mathrm{ESO} / \\
\text { Bachillerato }\end{array}$ & $\begin{array}{l}\text { Tanto en Fundamentos del arte II } \\
\text { como en Historia del arte, o como } \\
\text { contexto artístico dentro del periodo } \\
\text { contemporáneo de } 4^{\circ} \text { de ESO, se } \\
\text { puede tratar como valor transversal, } \\
\text { ya sea la igualdad entre sexos u otras } \\
\text { condiciones sexuales dentro del } \\
\text { mundo del arte de la época del Art } \\
\text { Déco. }\end{array}$ \\
\hline
\end{tabular}

\subsection{Conclusiones}

Esta propuesta sirve como referencia al equipo docente de los colegios e institutos que decidan ir articulando o ampliando una biblioteca de colores de libros ilustrados, en fun-ción de bloques temáticos y enmarcada en el currículum de cada una de las etapas edu-cativas. Hemos observado la facilidad del medio del cómic o álbum y sus códigos para la visibilidad de esta diversidad y también para adquirir la competencia lectoliteraria. Fomentar la lectura de esta forma nos asegura que podemos lograr desmentir prejuicios y estereotipos de género o visibilizar más fácilmente a ciertas personas.

Sin embargo, a pesar del amparo legal y los esfuerzos de la comunidad educativa por desestigmatizar al colectivo y dotarlo de reconocimiento, visibilidad e igualdad gracias, en parte, a la figura del coordinador/a de igualdad y convivencia, son conocidas las diferentes polémicas entre los grupos feministas en algunas definiciones del concepto de identidad. No obstante, debemos atender a la educación de todas las personas como derecho fundamental, y en todos los casos debemos asegurarnos de formar a futuros individuos de una sociedad activa, que, a pesar de la realidad que a veces vivimos, pretenda abrazar la justicia social con toda la diversidad existente entre la población. El estado de la cuestión para el personal docente que entra al aula a diario es que el alumnado actual ha ido mudando de conciencia y concibe esta diversidad en el aula sin cuestionamientos, de hecho puede encontrar diferentes materiales audiovisuales o en las redes sociales. Esto nos lleva a pensar que una gran mayoría concibe esta diversidad y convive con ella.

No obstante, también existe otro sector que realmente preocupa: aquellos que se resisten, bien por un gran peso cultural en las familias; o bien, por mensajes subversivos de la 
sociedad y que promueven un sistema totalmente contrario, de rechazo. Eso rara vez lo podemos cambiar. Por eso, este es precisamente el momento en que, desde el aula, no deberíamos dejar de insistir y hacerlo presente más que nunca como tema transversal, pero también de contenido y reflexión. La educación no ha dejado de ser un arma política desde el inicio de la España democrática, pero es importante evitar que los derechos humanos se reconozcan solamente en un color ideológico. De esta manera, permitiremos que se asienten estas bases para la justicia social en un sistema educativo inclusivo.

\subsection{Referencias bibliográficas}

ALTARRIBA, A. (2003). Enseñar con viñetas. Peculiaridades y aplicaciones didácticas de la historia. Mosaico, 10, págs.4-9.

BALLESTER, J. (2015). La formación lectora y literaria. Graó, caps. 3 y 4, págs.105198.

BALLESTER, J. e IBARRA, N. (2013). La tentación diabólica de instruirse. Reflexiones a propósito de la educación lectora y literaria. Ocnos, 10, págs.7-26.

BARBÉ I SERRA, A.; CARRO, S.; VIDAL, C. (2014) La construcción de las identidades de género. Actividades para trabajar con jóvenes y adolescentes. Madrid: Catarata.

BARRÈRE UNZUETA, M. Á. (2010). La interseccionalidad como desafío al mainstreaming de género en las políticas públicas. Revista Vasca de Administración Pública, 87-88, págs. 225-252.

BEAUVOIR, S. de (2011). El segundo sexo. Madrid: Cátedra (año de publicación del libro original; 1949).

BOWKETT, S. \& HITCHMAN, T. (2016). La utilización del cómic para mejorar la expresión oral, la lectura y la escritura. San Sebastián de los Reyes: Morata. [s[L"?

BUTLER, J. (2004). Lenguaje, poder e identidad. Madrid: Síntesis.

CASTELAR, A. F. (2014). Sobre la diversidad sexual en la escuela. Educación y ciudad, 26, págs. 77-86.

CERRILLO, P. C. (2007). Literatura Infantil y Juvenil y educación literaria. Hacia una nueva enseñanza de la literatura. Octaedro.

COLOMER, T. (dir.) (2002). Siete llaves para valorar las historias infantiles. Fundación Germán Sánchez Ruipérez.

CÓRDOBA GARCÍA, D. (2003). Identidad sexual y performatividad. Athenea Digital, 4, págs. 87-96. Recuperado de http://antalya.uab.es/athenea/num4/cordoba.pdf. iswep?

Decreto 87/2015, de 5 de junio, del Consell, por el que se establece el currículo y se desarrolla la ordenación general de la Educación Secundaria Obligatoria y del Bachillerato en la Comunitat Valenciana. Recuperado de https://www.dogv.gva. es/datos/2015/06/10/pdf/2015 5410.pdf. 
Decreto 108/2014, de 4 de julio, del Consell, por el que se establece el currículo y se desarrolla la ordenación general de la educación primaria en la Comunitat Valenciana. Recuperado de http://www.dogv.gva.es/datos/2014/07/07/pdf/2014 6347. pdf.

FELGTB \& COGAM (2012). Acoso escolar y riesgo de suicidio en adolescentes y jóvenes $L G B$. Recuperado de http://www.felgtb.org/rs/1584/d112d6ad-54ec-438b9358-4483f9e98868/91c/filename.

GUZMÁN LÓPEZ, M. (2011). El cómic como recurso didáctico. Pedagogía Magna, no 10 , págs. $122-131$.

HIDALGO, A. \& MCCAUSLAND, E. (2018). Representación, autoría y estrategias queer en el cómic contemporáneo. Tebeosfera, no 6, Tercera época. Recuperado de https://www.tebeosfera.com/documentos/representacion autoria y estrategias queer en el comic contemporaneo.html.

Ley 23/2018, de 29 de noviembre, de igualdad de las personas LGTBI. Boletín Oficial del Estado, núm. 10, de 11 de enero de 2019, págs. 1882-1917. Recuperado de https://www.boe.es/boe/dias/2019/01/11/pdfs/BOE-A-2019-281.pdf.

MARTXUETA PÉREZ, A. \& ETXEBERRIA MURGIONDO, J. (2014). Claves para atender la diversidad afectivo-sexual en el contexto educativo desde un enfoque global escolar. Revista Española de Orientación y Psicopedagogía, vol. 25, núm. 3, págs. 121-128.

MENDOZA FILLOLA, A. (2004) La educación literaria: bases para la formación de la competencia lecto-literaria. Archidona: Aljibe.

PICHARDO GALÁN, J. I. \& DE STÉFANO BARBERO, M. (2013). El alumnado de Secundaria ante la diversidad sexual. En Pichardo Galán, J. I. (coord.). Diversidad sexual y convivencia: una oportunidad educativa. FELGTB, Google y Transformarse para transformar, págs. 76-97.

PLATERO MÉNDEZ, L. (2013). La interseccionalidad en las políticas públicas sobre la ciudadanía íntima. Los discursos y la agenda política española (19952012). Tesis doctoral. UNED. Recuperado de: http://e-spacio.uned.es/fez/eserv. php?pid=tesisuned:CiencPolSoc-Rplatero\&dsID=Documento.pdf.

POSADA KUBISSA, L. (2014). Teoría queer en el contexto español. Reflexiones desde

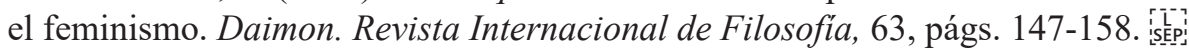

SÁNCHEZ SÁINZ, M. (2013). Las diversidades y la diferencia en educación Infantil y Primaria. En Pichardo Galán, J. I. (coord.). Diversidad sexual y convivencia: una oportunidad educativa. FELGTB, Google y Transformarse para transformar, págs. 53-75.

SUBIRATS, M. (1994) «Conquistar la igualdad: la coeducación hoy» en Revista Iberoamericana de Educación, 6. Monográfico Género y Educación, págs. 49-77. 


\title{
Capítulo 6 La llegada a la otra cara de la Luna: eclipsadas por los hombres
}

\author{
Rocío Domene-Benito \\ Depto. Didáctica de la Lengua y la Literatura \\ Universidad de Valladolid
}

\subsection{Introducción}

En el año 2019 se conmemora el quincuagésimo aniversario de la llegada de la humanidad a la Luna. Aunque el eslogan, más bien publicitario, que se ha querido resaltar desde aquel 21 de julio de 1969 sea "Un pequeño paso para el hombre; un gran salto para la humanidad", lo cierto es que ese pequeño paso también experimentó una necesaria y significativa contribución femenina. Las imágenes retransmitidas por televisión nos permitían observar cómo un hombre llamado Neil Armstrong pisaba por primera vez el astro lunar. Sin embargo, detrás de esa instantánea hubo rostros femeninos como los de la científica Margaret Hamilton y las conocidas como las "Computadoras del Área Oeste": Katherine Johnson, Mary Jackson y Dorothy Vaughan. Por tanto, el principal objetivo de este capítulo será la recuperación de la historia desde una perspectiva de género a través de la educación literaria; así como enfatizar una educación feminista y de convivencia e igualdad con el Otro, que tradicionalmente ha sido caracterizado desde el prisma femenino, más débil y vulnerable y, por ello, menos tenido en cuenta en tanto que silenciado y oculto en sus logros. En esta misma línea de pensamiento, promovemos la utilización de un recurso multimodal que aquí consideraremos como un artefacto cultural y artístico que es, sin duda, el álbum ilustrado y las innumerables herramientas didácticas que se pueden explotar en el aula a través del mismo.

En cuanto a la estructura del capítulo, consta de las siguientes secciones. Una primera aproximación histórico-cultural al hito de la llegada a la Luna y a la recuperación de esa historia en clave femenina que se ocultó aquel mes de julio de 1969. Seguidamente, nos centraremos en la educación literaria y cómo a través de la interculturalidad y el feminismo se pueden acercar a los lectores realidades heterogéneas y de igualdad de género que fomenten su espíritu crítico y capacidad de empatía. La siguiente sección versará sobre 
los beneficios del álbum ilustrado como garantía de la educación literaria intercultural y feminista que promulgamos. Tras estos primeros epígrafes de carácter más teórico, la Luna y su simbología adquieren relevancia en una sección donde haremos un recorrido a través de las distintas acepciones lunares, desde su carácter más científico como astro hasta sus peculiaridades en el ámbito de la imaginación y el romanticismo y cómo estas permiten a los pequeños lectores desarrollar el pensamiento crítico, la imaginación y la creatividad. Después, observaremos estas matizaciones en sendos álbumes ilustrados donde las mujeres y la Luna son las principales protagonistas. Finalmente, se describe una propuesta didáctica basada en estos materiales que combinan tanto el lenguaje visual como el narrativo, así como algunas consideraciones finales.

\subsubsection{Un hito histórico desde una perspectiva feminista: Los rostros femeninos detrás de la llegada a la Luna}

Tal y como hemos expuesto en la introducción, el día de la llegada a la Luna millones de personas enfrente de su televisor vieron cómo un astronauta varón de nacionalidad norteamericana era el primer ser humano en poner su pie en la superficie lunar. Sin embargo, tales retransmisiones solo se centraron en el hecho en sí y no se preguntaron cómo se produjo, es decir, obviaron los entresijos de fondo que una expedición de esa envergadura llevaba consigo. Dichos entresijos tuvieron rostro femenino también. En este sentido, no se pretende realizar un ejercicio de reescritura de la historia sino de contarla tal cual fue, sin restar importancia a la Otredad, en este caso, representada por la figura femenina. En el caso de la llegada a la Luna, los rostros femeninos que la impulsaron quedaron relegados a un mero papel secundario o más bien al ostracismo y a la opacidad. Por ello, en esta sección, no solo atenderemos a las vicisitudes de tal hallazgo en torno a las figuras de Armstrong, Alvin, Buzz y Collins sino también y en el mismo grado de notoriedad a las ya citadas Margaret Hamilton, Katherine Johnson, Mary Jackson y Dorothy Vaughan porque "NIÑAS y NIÑOS, juntos somos invencibles" (Domene, 2019, pág. 88). Recalcamos, por ende, la productividad y eficacia de los grupos de trabajo mixtos como el que ya hace 50 años logró que una persona caminara por primera vez sobre la superficie lunar. Por este motivo, los personajes que configuraron un episodio de tal magnitud para la historia de la humanidad deben ser reconocidos, incluyendo, claro está, la figura de ese Otro femenino que comentábamos previamente.

La Otredad ha sido objeto de estudio a lo largo de la historia y casi siempre ha aglutinado rasgos negativos y alejados de los estándares considerados como bellos y armónicos. Desde salvaje o bárbaro hasta extranjero pasando por exótico, estos y otros calificativos claramente estereotipados y desfavorables han sido seña de identidad del Otro. Es, asimismo, especialmente relevante la visión que plantea Sartre (1943) en torno a esta concepción del Otro como un ente indivisible del Yo, es decir, el Yo y el Otro forman una pareja indisoluble en el sentido que ese Otro siempre está presente en nuestras vidas y 
se manifiesta en acciones cotidianas y de tanto valor simbólico y moral como el respeto, el rechazo, la tolerancia o la empatía. Dicha pareja ha existido siempre a lo largo de la historia en forma de persona afroamericana, persona de bajos recursos económicos o mujer. Sin embargo, hasta los últimos años no hemos observado cómo el auge del movimiento feminista que reivindica la igualdad en todos los ámbitos públicos y privados pretende revalorizar esa figura del Otro femenina. En sintonía con lo anterior, Octavio Paz profundiza y contempla la visión del Otro como un elemento imprescindible en la configuración del ser humano y lo expresa de la siguiente manera: "El precipitarse en el Otro se presenta como un regreso a algo del que fuimos arrancados. Cesa la dualidad, estamos en la otra orilla" (1956, pág. 127). En definitiva, el Otro ha existido siempre, no podemos entender nuestra existencia sin esta figura que nos permite profundizar mejor en nuestro propio Yo. El Apolo 11 y sus integrantes conformaban un equipo donde las mujeres tuvieron un papel decisivo que, a continuación, analizaremos con detalle. Por tanto, tras esta reflexión, podemos concluir que no se puede entender la llegada a la Luna sin el Otro femenino, lo que denominaremos aquí como el descubrimiento de la otra cara de la Luna, eclipsada por los hombres.

La otra cara de la Luna es la denominación que hemos escogido en este capítulo para contar la historia desde la perspectiva de esa Otredad negada hace 50 años, una Otredad compuesta por un grupo de mujeres que ayudaron con sus investigaciones, estudios, esfuerzo y dedicación a que el astronauta más universal contemplara la Luna de cerca por primera vez en la historia. Para ello, describiremos por separado a cada una de las mujeres que compuso el grupo y finalmente realizaremos una reflexión conjunta sobre cómo la unión de fuerzas entre ambos sexos ayuda a conseguir importantes hitos y hallazgos históricos.

En primer lugar, analizaremos la figura de Margaret Hamilton, la mujer que diseñó el programa y codificó el software que hizo posible que el Apolo 11 llegara a la órbita lunar. En una reciente entrevista en el diario El País (2018), la científica estadounidense confiesa que pensó más en el adecuado funcionamiento del programa que en la propia llegada a la Luna. Además, expone la importancia del trabajo sobre la prevención de errores, ya que la responsabilidad era máxima y un fallo hubiera tenido fatales consecuencias. Así mismo, destaca la importancia de su formación no solo como matemática sino también en filosofía, ya que la tecnología es una disciplina transversal. En este sentido, si extrapolamos estas palabras a la actualidad, podemos considerar a Margaret un modelo para todas las niñas que sueñen con ser científicas y que sepan que la tecnología y las humanidades se enriquecen mutuamente. En relación con la igualdad y la conciliación, en otra entrevista en The Guardian (2019), añade lo siguiente: "I was fortunate to have a very modern husband. There were some men who understood equality" ("Tuve la suerte de tener un marido muy moderno. Había algunos hombres que comprendían la igualdad"). Como podemos observar, Hamilton construyó un equipo eficaz con su marido en aras de la igualdad, la libertad y la lucha por las metas y los sueños. También, con su hija, a la que frecuentemente llevaba al laboratorio: "She liked to imitate me - playing astronaut. She started hitting keys and all of a sudden, the simulation started" ("Le gustaba 
imitarme -jugar a ser astronauta. Empezó a pulsar botones y, de repente, la simulación comenzó”). En suma, gracias al esfuerzo, tesón, ilusión y trabajo duro de Hamilton y su familia, esta científica pudo contribuir a que el equipo de astronautas pudiera llegar a la Luna y regresar con seguridad. Por todo lo anterior, consideramos que personajes como Margaret son modelos y referentes necesarios tanto para las niñas como para los niños del siglo XXI, ya que historias como estas contribuyen al desarrollo integral del ser humano desde la niñez en valores como la empatía, la solidaridad, la igualdad y la meritocracia.

En segundo lugar, es menester analizar las figuras de las denominadas como las "Computadoras del Área Oeste": Katherine Johnson, Mary Jackson y Dorothy Vaughan. Para ello, seguiremos a Noragueda (2017), que habla de sus biografías en alusión a la película Hidden Figures, de Theodore Melfi, que retrata la vida de tres mujeres afroamericanas que contribuyeron con su incansable trabajo a la carrera espacial. En cuanto a Katherine Johnson, podemos destacar que fue la primera mujer afroamericana que estudió un posgrado en la Universidad de Virginia Occidental gracias al apoyo familiar y a su afición a las matemáticas. Además, también invirtió su tiempo y dedicación en calcular la trayectoria del primer vuelo espacial de la NASA o del que el Apollo 11 hizo a la Luna. Por su parte, Dorothy Vaughan fue la primera supervisora afroamericana de un departamento de la NASA, el de cálculo de trayectorias de vuelo. Por lo que respecta a Mary Jackson, podemos enfatizar que fue la primera mujer afroamericana ingeniera de toda la NASA. Estas tres mujeres comparten, como ya hemos comentado, el hecho de ser afroamericanas y mujeres, dos características intrínsecas de la Otredad y de las minorías. En una época dominada por la segregación racial, gracias a su esfuerzo, perseverancia y lucha intelectual, lograron objetivos impensables para personas de su etnia y sexo. Así, tal y como reza el título del libro de Margot Lee Shetterly, Hidden Figures: The American Dream and the Untold Story of the Black Women Mathematicians Who Helped Win the Space Race ("Figuras Ocultas: el Sueño Americano y las historias no contadas de las mujeres negras que ayudaron a ganar la carrera espacial") (2016), estas tres mujeres contribuyeron de forma decisiva y sustancial al sueño americano ligado con la carrera espacial. Tampoco podemos obviar el papel como analista que tuvo la matemática Christine Darden quien hizo frente, como las tres mujeres citadas anteriormente, a barreras de género, y así lo exponía: "I was able to stand on the shoulders of those women who came before me, and women who came after me were able to stand on mine". ("Pude auparme a hombros de las mujeres que me precedieron, y las mujeres que me siguieron pudieron auparse sobre mis hombros"). Por tanto, consideramos de vigente relevancia dar a conocer sus historias y dar voz a todas estas mujeres que tradicionalmente han sido silenciadas en el discurrir de la historia.

En consideración a este silencio premeditado, García Manzanares (2005, pág. 8) apunta a estas consideraciones en el prefacio de una obra colectiva:

La Historia nos da la medida de aquello a lo que hemos concedido importancia y a través de sus relatos constatamos lo que se ha considerado importante durante siglos. Así, comprendemos que "la objetividad, los hechos y el pasado" se han hecho descansar sobre los varo- 
nes. Se atribuye a estos, sin necesidad de mayor explicación, la capacidad de expresarse, de saber formular y comunicar el pensamiento, de imponer sus afirmaciones. A las mujeres, por el contrario, se les atribuye el silencio. Se puede afirmar que la historia de las mujeres es la historia del silencio, de ahí su invisibilidad.

Compartimos las afirmaciones anteriores, que nos permiten comprender el porqué de la ausencia de conocimiento acerca de, en este caso, el rol femenino en la llegada a la Luna, esa otra cara que es necesaria y que forma parte de la justicia social que legitima el dar a conocer este hito desde edades tempranas.

Así pues, si focalizamos nuestra atención en el rol de la mujer en la carrera científica del que figuras como los rostros femeninos de la llegada a la Luna forman parte, observamos cómo las mujeres científicas se cuestionan sobre la imperante necesidad de la igualdad de género en el ámbito científico. En este sentido, Sánchez et al. (2017, págs. 97-98) reflexionan sobre la insuficiencia de incorporar mujeres a la carrera científica solo por cubrir unas normas preestablecidas y abordan la construcción de un modelo avalado por la ciencia feminista que aboga por el potencial de las mujeres al añadir una nueva perspectiva desde un prisma eminentemente práctico y productivo, es decir, formando equipos mixtos con los mismos grados de responsabilidades y competencias. Por tanto, la inclusión no es una simple suma de números (2017, pág. 100). Finalmente, las autoras se preguntan si, pese a los impulsos legislativos provenientes de las instituciones en diferentes países, los hombres y las mujeres serán capaces de trabajar conjuntamente a favor de la equidad y la igualdad en la ciencia (2017, pág. 103). Con el mismo objetivo, Magallón (2017) calibra las ventajas que los estudios de género aportan a la ciencia y a la vida. Subraya la investigadora turolense (2017, pág. 109) que las visiones estereotipadas en cuanto al género han impedido estudiar en profundidad y hacer frente a problemas como pueden ser las enfermedades cardiovasculares. Si contemplamos esta teoría, podemos concluir que, de esta misma manera, el estudio de la llegada a la Luna como una proeza por parte de unos astronautas, sin tomar en consideración todo el trabajo previo y posterior que hubo detrás de la icónica imagen, queda incompleto y estereotipado.

En recapitulación, la ciencia y la mujer son realidades que se nutren conjuntamente y deben ser revalorizadas y fomentadas desde la infancia. Por lo tanto, en la siguiente sección intentaremos plantear cómo a través de una educación literaria intercultural y feminista se pueden ofrecer a las herramientas que les permitan desarrollar unas competencias lectoras y literarias del siglo XXI basadas en la igualdad de género y en la justicia social.

\subsection{Educación literaria, interculturalidad y feminismo}

Como se ha indicado previamente a fin de revalorizar el hito de la llegada a la Luna desde una perspectiva feminista e inclusiva, tomaremos la educación literaria como una herramienta indispensable para conseguir lo que Dueñas (2013, págs. 141-142), siguiendo a Moreno Verdulla, califica como "nivel de competencia lectora óptimo" que no podrá conseguirse sin propiciar: "encuentros significativos, satisfactorios, con los textos literarios, que alimenten el deseo de seguir leyendo” (2013, pág. 142). Por tanto, es 
deber imperativo de la escuela fomentar una educación literaria que ayude al alumnado a formarse como lector autónomo que disfruta del placer de la lectura (Rosenblatt, 1978).

Llegados a este punto, nos planteamos cuestiones como: ¿qué tipo de lectura? ¿Cómo se realiza esta lectura? ¿Con qué objetivos? Sin duda, se trata de tres problemáticas complicadas de dirimir. Sin embargo, intentaremos aportar una respuesta razonada a cada una de ellas. Por lo que respecta a la primera, tradicionalmente los temas de la literatura infantil y juvenil (LIJ, en adelante) se han centrado en aspectos como la familia, el crecimiento del niño, la naturaleza, las aventuras, las princesas o los piratas. Con referencia a estos últimos, podemos observar cómo los estereotipos de género están presentes desde la infancia con lecturas indicadas como adecuadas para niñas y otras para niños. Recordemos aquí el caso de uno de los primeros ejemplos de la LIJ, A Little Pretty Pocket (1744) donde incluso se regalaba un juguete diferente en función del sexo del lector. Y, así, podríamos concatenar muchos más ejemplos. No obstante, en la actualidad, debido a una notable proliferación de obras dirigidas al público infantil y juvenil y, especialmente, del álbum ilustrado (del que nos ocuparemos más adelante), temáticas tradicionalmente consideradas "tabú" han ido adaptándose a la centuria actual, la de la interculturalidad. Así pues, pueden apreciarse ejemplos de lo que Cicerchia (1999) denomina como "formas familiares", es decir, una redefinición del concepto familia en que a la nuclear tradicional se han unido monoparentales, homosexuales, etc. De forma similar, aparecen nuevas publicaciones que pretenden huir de los estereotipos de género, como álbumes ilustrados centrados en concienciar a las futuras generaciones de la nopredeterminación de una profesión en función del género. En este sentido, enfatizamos la necesidad de mostrar mujeres científicas, matemáticas y astronautas, entre otras.

La segunda cuestión que nos planteábamos sobre cómo leer y el proceso lector nos remi-te incuestionablemente a las premisas indicadas por Ballester (2007), quien enfatiza el hecho de la superación de la concepción de la lectura como un simple desciframiento de signos gráficos. Para el investigador valenciano, la lectura debe ser entendida como un proceso de interpretación de todos aquellos mensajes que nos quiere transmitir un deter-minado texto y/o imagen. Y, aquí, recuperamos las directrices de Mendoza (2001) sobre el intertexto-lector, que son realmente esclarecedoras, ya que dan todo el protagonismo al lector y a las distintas interpretaciones que puede tener un mismo texto/imagen. Por ende, podríamos unir esta segunda cuestión con la tercera, que versa sobre los objetivos de dicha lectura, los cuales, como comprobaremos con el posterior análisis de materiales y la propuesta didáctica, se podrían definir como interculturales, ya que persiguen el fomento de valores como la solidaridad, la empatía, la justicia social y la igualdad de género.

En esta misma línea argumentativa, la interculturalidad adquiere un papel fundamental en la educación literaria, pues desde esta perspectiva se pueden desarrollar lo que Agua-do (2003, pág. 141) denomina “competencias interculturales". 
un clima educativo donde las personas se sientan aceptadas y apoyadas por sus propias habilidades y aportaciones, así como a permitir la interacción efectiva y justa entre todos los miembros del grupo.

Este enfoque puede aplicarse a la Otredad femenina de la que hablábamos previamente. Por ejemplo, en el caso de las tres afroamericanas que participaron en la carrera espacial, quienes compartían la condición de pertenecer a un grupo étnico tradicionalmente denostado y la de ser mujeres. Por tanto, se adopta el prisma de la interculturalidad, comprendida como una interacción entre culturas y como un diálogo permanente entre la pareja indisoluble que forman el Yo y el Otro.

Asimismo, dentro de la etiqueta de la interculturalidad, no podemos obviar la eminente figura del Otro femenino. Se hace, por ello, imprescindible, promover una educación literaria feminista con la igualdad de género como principal baluarte. Para ello, debemos impregnar la educación literaria tanto en sus objetivos como en su metodología y en sus materiales de feminismo, que es definido por Sau (2000) como un movimiento político y social que denuncia la invisibilidad de las mujeres y la posibilidad de conseguir un Estado no patriarcal. A esto, añadiríamos también que es un movimiento educativo, ya que desde la educación y, en especial, desde la literatura se pueden acercar a los pequeños lectores realidades interculturales y heterogéneas donde las mujeres también participan en la llegada a la Luna y en otros hitos importantes de la humanidad. En este sentido, tal y como establece Martel de la Coba (2005, pág. 9), existen unos "valores fundamentales que se entrecruzan y superponen en los debates pasados y presentes: la igualdad, la libertad, la justicia y la diversidad". Así, con estas premisas en consideración, defendemos una educación literaria intercultural y feminista con los valores que propone esta autora.

Para concluir este apartado, reivindicamos el rol que la educación literaria intercultural y feminista adquiere en la recuperación de historias como la que hemos denominado aquí, como la llegada a la otra cara de la Luna. Son necesarias y, para ello, la literatura se convierte en una aliada muy significativa y, en especial, el álbum ilustrado y la poderosa imbricación que se produce entre imagen y texto al leerlo. Así, en la siguiente sección analizaremos los beneficios de esta singular herramienta que fomenta el desarrollo integral del ser humano desde la infancia a través del lenguaje visual y narrativo.

\subsection{El álbum ilustrado y sus beneficios}

En la actualidad el álbum ilustrado goza de una gran popularidad, pero no fue hasta finales del siglo pasado cuando se produjo su eclosión como fenómeno literario, especialmente como soporte para la LIJ. Desde el considerado como el primer álbum ilustrado, Orbis Pictus, hasta el momento presente, han sido muchos los autores e ilustradores que han contribuido a su desarrollo. Así, gracias a los avances acaecidos en la era digital, el álbum ilustrado ha dejado de considerarse un "simple" libro para pasar a ser un artefacto cultural e incluso un juguete para los primeros lectores. Esta definición de Hoster y Gómez (2013) nos parece acertada, ya que manifiesta la magnitud del álbum: 
El álbum ilustrado es un producto estético, artístico y, a menudo, didáctico: narra historias o nos transmite emociones, pero también constituye un material ideal para formar lectores competentes, capaces de enfrentarse a obras complejas. Acercarnos a niños y jóvenes con este nuevo material es un reto porque, si bien la educación literaria ha privilegiado durante mucho tiempo el texto escrito, hay que aceptar que la lectura de la imagen cobra cada vez más relevancia a medida que su presencia en la vida cotidiana aumenta; y las características del álbum ilustrado lo convierten en un recurso idóneo tanto para la iniciación a la competencia literaria como para el afianzamiento de la habilidad lectora en los jóvenes.

Suscribimos, por tanto, las afirmaciones anteriores donde el texto no prevalece sobre la palabra, sino que se nutren y se enriquecen mutuamente, de forma similar a la pareja entre el Yo y el Otro. También, destacamos el calificativo de didáctico ya que, como veremos en la sección dedicada a la propuesta educativa, el álbum ofrece muchas posibilidades no solo en la enseñanza/aprendizaje de la lengua y la literatura, sino también de ciencias sociales, naturales, música o artes plásticas.

Así, en colación a los beneficios del uso de álbumes ilustrados en las aulas como herramientas en la educación literaria intercultural y feminista, resaltaremos los siguientes: (1) el poder combinatorio de la imagen y el texto, (2) la capacidad de generar emociones, (3) la promoción del pensamiento crítico, la imaginación y la creatividad, (4) la permeabilidad para adaptarse a la didáctica de distintos campos: lengua y literatura, ciencias sociales, ciencias naturales, artes, etc. y (5) la identificación con un juguete/objeto desde edades tempranas. En cuanto al primero de ellos, un referente como Nodelman (1988, pág. 153) expresa lo siguiente:

...the pictures focus our attention on specific aspects of the words and cause us to interpret them in specific ways. As a result, a picturebook contains at least three stories: the one told by the words, the one implied by the pictures, and the one that results from the combination of the first two?

Atribuye el investigador a la combinación entre imagen y texto la posibilidad de generar diferentes tipos de historias, en concreto, tres que, multiplicadas por los beneficios segundo y tercero de la lista previa, ofrecen al lector un ilimitado generador de historias. Así, gracias a las emociones, al pensamiento crítico, a la imaginación y a la creatividad, desde la infancia se fomenta la "creación" de niñas y niños librepensadores y críticos. Por lo que respecta al cuarto beneficio, como veremos en sucesivas secciones, el álbum ilustrado no solo es útil para enseñar lengua y literatura, sino también para profundizar en otras áreas del conocimiento a través de la lectura. Finalmente, el último de los beneficios destierra la visión de un libro como objeto de lectura únicamente, ya que intervienen el resto de los sentidos, como pueden ser el tacto.

Seguidamente, centramos nuestro interés en los materiales seleccionados que posteriormente formarán parte de la propuesta didáctica. Entre las características principales que comparten sendos materiales están estas dos: son álbumes ilustrados y muestran la lle-

9Las imágenes centran nuestra atención en aspectos específicos de las palabras y nos hacen interpretarlas de maneras concretas. Como resultado, un álbum ilustrado contiene al menos tres historias: la que narran las palabras, la que insinúan las imágenes y la que resulta de la combinación de ambas. 
gada a la otra cara de la Luna tanto de manera científica como simbólica, con personajes femeninos como protagonistas.

\subsection{Análisis de los materiales}

Tras la descripción exhaustiva de lo que podríamos considerar el marco teórico del capítulo con referencia a la educación literaria, la interculturalidad, el feminismo y el álbum ilustrado, así como el rol histórico de la mujer en la llegada a la Luna, nos disponemos a analizar los materiales seleccionados, a partir de los cuales se propondrán una serie de actividades multidisciplinares.

Por lo que respecta a la estructura de esta sección, se ha dividido en dos subapartados. El primer apartado inicia con algunas consideraciones previas y los criterios de selección utilizados, así como la lista con los álbumes escogidos. Por su parte, en el segundo se analizan de manera pormenorizada los álbumes, con especial énfasis en la simbología que nos ofrece la Luna en cada uno de ellos.

\subsubsection{Consideraciones previas y criterios de selección}

Hemos escuchado muchas veces cómo las lecturas realizadas durante la infancia influyen decisivamente en el desarrollo del ser humano de manera integral como personas, no solo en lo que atañe a su formación intelectual, cultural y académica, sino también personal en cuanto a la adquisición y el fomento de valores y de un estilo de vida. Así, cuando nos preguntamos cómo seleccionar un libro para niños, qué características debe tener, qué tipo de personajes, qué temas y qué tramas deben aparecer, debemos hacerlo con la convicción de que esa obra pueda ayudar al lector en cuestión a ser un mejor ciudadano. Por tanto, ¿cómo se mide la calidad de un libro? Es un hecho que nuestra vida es limitada y no podemos leer todo. Tal y como expresa Bloom (1995, pág.42): “solo poseemos un intervalo". Asimismo, discute la problemática del canon, ¿qué es más apropiado leer?, ¿qué aspectos definen la calidad de un libro? Para este autor, sin duda, los valores estéticos perviven por delante de cualquier característica moral o social, ya que (1995, pág. 25): "leer a los mejores escritores- pongamos a Homero, Dante, Shakespeare, Tolstói -no nos convertirá en mejores ciudadanos". Bajo estas premisas, valor estético y valores socio-cívicos, ¿en qué nos basamos para calificar un libro como una muestra literaria de calidad?, ¿por qué no combinar ambas? Un libro infantil puede tener valores estéticos y también promulgar un mensaje cívico y moral. Así pues, estos serán los criterios generales que utilizaremos para seleccionar las obras que posteriormente serán los materiales para la propuesta didáctica, una propuesta intercultural y feminista, por consiguiente, donde las mujeres tengan voz, así como una representación libre de estereotipos de las diferentes culturas.

En consonancia con los criterios que acabamos de describir, hemos seleccionado una serie de álbumes ilustrados que, a nuestro juicio, cumplen con el hecho de poseer cualidades estéticas (tanto del texto como de la imagen) y, al mismo tiempo, fomentan la educación emocional y la educación en valores donde el Otro femenino adquiere una 
especial relevancia. Además, en cuanto a la temática, hemos tenido presente el hito histórico de la llegada a la Luna desde la figura del Otro femenino y también hemos prestado atención a la simbología de la Luna en tanto ente imaginario/romántico y astrofísico.

A continuación, mostramos una tabla con los títulos seleccionados y un breve resumen del argumento de los mismos:

Tabla 1. Título y argumento de los álbumes ilustrados seleccionados

\begin{tabular}{|l|l|}
\hline \multicolumn{1}{|c|}{ Título } & \multicolumn{1}{c|}{ Argumento } \\
\hline Margaret and the Moon (2017) & $\begin{array}{l}\text { Narración de la historia real de Margaret } \\
\text { Hamilton, la mujer que codificó el software } \\
\text { que permitió la llegada a la Luna. }\end{array}$ \\
\hline $\begin{array}{l}\text { Hidden Figures: The True Story of Four Black } \\
\text { Women and the Space Race (2018) }\end{array}$ & $\begin{array}{l}\text { Narración de la historia real de cuatro mujeres } \\
\text { que contribuyeron notablemente en la carrera } \\
\text { espacial. }\end{array}$ \\
\hline $\begin{array}{l}\text { Catching the Moon: The Story of a Young Girl's } \\
\text { Baseball Dream (2005) }\end{array}$ & $\begin{array}{l}\text { Descripción metafórica de la ilusión de una } \\
\text { niña que sueña con ser jugadora de béisbol y } \\
\text { así alcanzar su luna imaginaria. }\end{array}$ \\
\hline Aliana reaches for the Moon (2019) & $\begin{array}{l}\text { Narración de la historia de una niña apasionada } \\
\text { por el astro lunar. }\end{array}$ \\
\hline Ladder to the Moon (2011) & $\begin{array}{l}\text { Narración de la historia de una abuela y una } \\
\text { nieta que nunca se conocieron con la Luna } \\
\text { como testigo. }\end{array}$ \\
\hline Franklin and Luna go to the Moon (2018) & $\begin{array}{l}\text { Narración de la historia de una niña y su } \\
\text { amigo dragón que viajan a la Luna en busca de } \\
\text { respuestas a sus preguntas. }\end{array}$ \\
\hline
\end{tabular}

Fuente: Elaboración propia (2019)

Dada la diversa simbología que puede adoptar la Luna, centraremos el análisis de estos álbumes en dichas concepciones, desde la Luna interpretada con un halo romántico y metafórico hasta la Luna más factual como un astro al igual que el sol.

\subsubsection{La simbología de la Luna: ente imaginario/romántico versus astro}

Tal y como se acaba de indicar, la primera división que haremos en el estudio de los álbumes hará referencia a la Luna. Sin embargo, consideramos pertinente comentar las semejanzas que contemplamos en todos los álbumes como introducción previa. En este sentido, los cinco álbumes seleccionados comparten el protagonismo de la Otredad femenina, es decir, todos están protagonizados o coprotagonizados por personajes femeninos. De igual modo, todos tienen en común el hecho de reflejar las distintas visiones que nos ofrece la Luna. Por tanto, como podemos comprobar, la Luna y la Otredad femenina serán las protagonistas indiscutibles de estas historias. Además, cabe reseñar que mediante la lectura de todos los álbumes se desarrolla el pensamiento crítico, la imaginación y la creatividad en tanto la consideración de la Luna y su funcionamiento 
como una materia dentro de las ciencias y la tecnología y su aproximación metafórica al imaginario romántico infantil.

Tras estas breves consideraciones iniciales, nos disponemos a realizar la división en torno a la simbología de la Luna. Por una parte, atenderemos a aquellos álbumes que presentan una visión más "real" de la Luna y, por otro lado, los que defienden su concepción romántica/imaginaria. Así, en la siguiente tabla apreciamos dicha división:

Tabla 2. División de los álbumes ilustrados seleccionados con respecto a la simbología de la Luna

\begin{tabular}{|l|l|}
\hline \multicolumn{1}{|c|}{ Luna: Astro } & \multicolumn{1}{|c|}{ Luna: Imaginación/Romanticismo } \\
\hline Margaret and the Moon (2017) & $\begin{array}{l}\text { Catching the Moon: The Story of a Young Girl's } \\
\text { Baseball Dream (2005) }\end{array}$ \\
\hline $\begin{array}{l}\text { Hidden Figures: The True Story of Four Black } \\
\text { Women and the Space Race (2018) }\end{array}$ & Ladder to the Moon (2011) \\
\hline Aliana reaches for the Moon (2019) & Franklin and Luna go to the Moon (2018) \\
\hline Franklin and Luna go to the Moon (2018) & \\
\hline
\end{tabular}

Fuente: Elaboración propia (2019)

Con referencias a la tabla precedente, debemos hacer una especificación, ya que uno de los títulos: Franklin and Luna go to the Moon, aparece en las dos clasificaciones porque, como comprobaremos más adelante, combina ambas concepciones de la Luna: como astro y como ente imaginario.

En primer lugar, exploraremos los álbumes cuya concepción de la Luna se atribuye a su tradicional visión como astro. En esta línea, observaremos cómo a través de la lectura de un álbum ilustrado no solo se aprende lengua y literatura, sino también ciencia ya que, a través por ejemplo de Margaret and the Moon, los lectores podrán leer sobre la historia real de la científica Margaret Hamilton y cómo consiguió codificar el software que permitió el hito de la llegada a la Luna. Del mismo modo, el otro de los álbumes catalogados como de no-ficción es Hidden Figures: The True Story of Four Black Women and the Space Race, que permite a los lectores conocer la historia real de cuatro mujeres matemáticas que también contribuyeron a la llegada a la Luna. Por tanto, estos dos álbumes reflejan cómo a través de la lectura de álbumes ilustrados se puede aprender ciencia. En el primero de ellos, destacaremos cómo el autor, Dean Robbins, inicia el álbum con una Margaret niña a la que le encanta resolver problemas matemáticos. Así, en esa primera ilustración observamos la cara de felicidad de Margaret en el inicio de su sueño. En el segundo, enfatizaremos la cualidad intercultural del álbum, ya que no solo se centra en el camino científico de las mujeres, sino también en sus raíces étnicas y culturales y en las barreras a las que tuvieron que hacer frente:

Because Dorothy was black and a woman, some people thought it would be impossible for her to get a job as a computer. She lived in Virginia, a southern state, where laws segregated, or kept apart, black people and white people. 
They could not eat in the same restaurants.

They could not drink from the same water fountains.

They could not use the same restrooms...

But Dorothy didn't think it was impossible. She was good at math. Really good (2019). ${ }^{10}$

Sin duda, estamos ante una muestra sobre cómo dar voz a la diversidad y ver cómo, a través del esfuerzo y la confianza en uno mismo, se pueden conseguir todas aquellas metas que nos propongamos.

En la misma línea que los anteriores pero, en este caso, de ficción, Aliana reaches for the Moon combina la parte más científica de la Luna con las cualidades de la niña, ya que Aliana tiene una gran imaginación: "Aliana has a big imagination and loves making things for her family, especially for her little brother Gustavo"11 (2019). Asimismo, otra de las características importantes del libro es que esta pequeña científica se convierte en un referente esencial para su hermano pequeño. En este sentido, el mensaje que se transmite a las niñas es que ellas también pueden ser modelos para sus hermanos y no solo al revés. Podríamos comparar este libro con el que versa sobre la vida de Margaret Hamilton, porque su protagonista es una niña que también sueña con crear cosas útiles para la humanidad, tal y como hizo la científica estadounidense. Por tanto, ambas obras, junto con la de las cuatro mujeres que también contribuyeron a la llegada a la otra cara de la Luna, constituyen poderosos materiales para mostrar a los aprendices historias reales en las que inspirar sus respectivas vidas.

En segundo lugar, examinaremos los álbumes seleccionados en torno a la temática de la Luna como un ente imaginario y romántico. Siguiendo a Loske y Massey (2018), comprobamos que ya el filósofo griego Plutarco escribió en el siglo I un diálogo ficticio en el que los distintos participantes reflexionaban sobre el aspecto de la superficie lunar y sobre la posibilidad de vida allí. Y así, hasta hoy, la Luna ha tenido un papel relevante, tanto en la literatura para adultos como en la LIJ, sobre todo en su contraposición con el sol y en la poesía. A continuación, nos centraremos en los dos álbumes seleccionados que identifican la Luna con una simbología metafórica. En el primero de ellos, Catching the Moon: The Story of a Young Girl's Baseball Dream, la Luna se convierte en el elemento simbólico que pretende alcanzar Marcenia. Por tanto, observamos un juego metafórico entre conseguir su sueño: asistir a un campamento de béisbol con niños pese a ser una niña sin recursos, y alcanzar la Luna: "Marcenia felt as proud and happy as if she had

10 "Debido a que Dorothy era negra y mujer, algunos pensaban que le resultaría imposible conseguir un empleo como computadora. Ella vivía en Virginia, un estado sureño de los Estados Unidos, donde las leyes segregaban, o mantenían separados, a las personas negras y blancas.

No podían comer en los mismos restaurantes.

No podían beber de las mismas fuentes de agua.

No podían utilizar los mismos baños...

Pero Dorothy no creía que fuera imposible. Se le daban bien las matemáticas. Pero que muy bien" (2019).

11 "Aliana tiene una gran imaginación y le encanta fabricar cosas para su familia, especialmente para su hermanito Gustavo". 
reached right up in the sky and caught the moon in her glove"12 (2005). Cabe reseñar, asimismo, la imagen que precede a este texto, donde una iluminada luna contempla a un padre y a una hija contentos, fundidos en un abrazo. Se trata, por tanto, de un álbum que muestra otra cara de la Luna, la Luna como motor y guía para conseguir los sueños, en este caso, de una niña rechazada al inicio por su condición de mujer.

Por lo que respecta al segundo álbum de este tipo, Ladder to the Moon recrea la historia de una nieta y una abuela que jamás se conocieron pero que logran abrazarse gracias a una escalera dorada que las reúne en la Luna. El mensaje del álbum nos muestra cómo, de nuevo, los imaginarios en torno a la Luna permiten la consecución de los sueños y solamente contemplando el astro los lectores pueden compartir tiempo con sus seres queridos ya fallecidos porque la Luna tiene ese poder de mantenerlos vivos. La Luna se muestra como un personaje más e, incluso, la madre de la protagonista la compara con la abuela fallecida: "She was like the moon, her mother replied. Full, soft and curious"13. Nos interesa especialmente el último adjetivo, ya que consideramos que la Luna también es un personaje llamativo para los niños y niñas curiosos, pues se trata de un ente simbólico y enigmático.

Finalmente, pasaremos a analizar Franklin and Luna go to the Moon que, como ya comentábamos previamente, es un ejemplo híbrido donde a la propia llegada a la Luna se suman aspectos esenciales para una educación literaria feminista e intercultural, como la imaginación o la creatividad. La protagonista, Luna, es aficionada a la lectura y a las historias: "Luna loves stories. Stories make her world feel bright"14 (2018) y, junto con su amigo Franklin, un dragón, decide embarcarse en la aventura de averiguar los orígenes de tan singular criatura. En el proceso, incluso encuentran a cinco vampiros leyendo a Shakespeare, hasta que finalmente deciden ir a la Luna y allí encuentran a un antepasado del dragón. Se trata, como podemos observar, de una historia diferente de las anteriores en el sentido de que tiene la parte más científica (incluso la tortuga de Luna se llama Neil Armstrong) y una parte más imaginaria, que es la que reside en el carácter soñador e imaginativo de la niña protagonista.

En recapitulación, como hemos demostrado, el personaje de la Luna ofrece numerosas combinaciones y significados que pueden aprovecharse, sin duda, en la promoción de una educación literaria intercultural y feminista con la igualdad de género como principal objetivo. Así pues, bajo estas consideraciones, se ha diseñado una propuesta didáctica basada en los materiales descritos en esta sección, que describimos con detalle en la siguiente.

\footnotetext{
12 "Marcenia se sintió tan orgullosa y feliz como si hubiera alcanzado el mismísimo cielo y capturado la luna con su guante" (2015).

13 "Era como la luna, respondió su madre: plena, suave y curiosa".

14 "A Luna le encantan las historias. Las historias hacen que su mundo resplandezca" (2018).
} 


\subsection{Propuesta didáctica}

Una vez analizados los materiales con los que vamos a trabajar en el aula, nos disponemos a presentar el diseño de las sesiones y las diferentes actividades. Así, en primer lugar, mostraremos los objetivos principales:

- Fomentar el desarrollo del pensamiento crítico, la imaginación y la creatividad.

- Promover el desarrollo del debate participativo y crítico, donde se respetan y se aprecian todas y cada una de las opiniones.

- Impulsar tanto el trabajo autónomo como en grupo.

- Mostrar al alumnado cómo a través de la lectura de álbumes ilustrados es posible aprender acerca de campos aparentemente tan dispares como la lengua y la tecnología, o la literatura y la ciencia.

- Dar a conocer la historia de la otra cara de la Luna, haciendo hincapié en su Otredad femenina.

Así, en comunión con estos objetivos, se diseñaron unas sesiones con unos contenidos concretos, que detallamos en la siguiente tabla:

Tabla 3. Resumen con las sesiones y sus contenidos

\begin{tabular}{|l|l|}
\hline \multicolumn{1}{|c|}{ Sesiones } & \multicolumn{1}{c|}{ Contenidos } \\
\hline La otra cara de la Luna: las olvidadas & $\begin{array}{l}\text { Lectura colaborativa en voz alta de algunos } \\
\text { fragmentos de Margaret and the Moon (2017)y } \\
\text { Hidden Figures: The True Story of Four Black } \\
\text { Women and the Space Race (2018). Debate } \\
\text { participativo y crítico. }\end{array}$ \\
\hline $\begin{array}{l}\text { El sueño lunar: Luna, Aliana, Suhaila y } \\
\text { Marcenia }\end{array}$ & $\begin{array}{l}\text { Lectura colaborativa en voz alta de algunos } \\
\text { fragmentos de Catching the Moon: The Story } \\
\text { of a Young Girl's Baseball Dream, Ladder } \\
\text { to the Moon, Franklin and Luna go to the } \\
\text { Moon y Aliana reaches for the Moon. } \\
\text { Debate participativo y crítico. }\end{array}$ \\
\hline Las heroínas lunares & $\begin{array}{l}\text { Actividad grupal. Selección de una de las } \\
\text { heroínas y explicación de su relación con la } \\
\text { Luna a través de la escritura o las artes plásticas }\end{array}$ \\
\hline
\end{tabular}

Fuente: Elaboración propia (2019)

Seguidamente, centraremos nuestro interés en la descripción detallada de cada una de las sesiones, que tendrán una duración de 50 minutos cada una, y están dirigidas a alumnado de inglés como lengua extranjera en el último curso de Educación Primaria (11-12 años):

Por lo que respecta a la sesión número uno, los dos álbumes ilustrados que recrean historias reales serán los materiales utilizados. Debido a la limitación temporal, se escogen 
una serie de fragmentos donde se ven las personalidades y los logros de las mujeres protagonistas y con los cuales se puede identificar el alumnado. El proceso lector sigue las vicisitudes promulgadas por Roché (2015), quien aboga por los beneficios de la lectura colaborativa en voz alta, que provoca reacciones en los aprendientes como la formulación de preguntas, de porqués y la diversidad de respuestas. También alude la autora a la necesidad del respeto de los turnos y de la heterogeneidad de pensamientos y creencias. Así pues, esta primera sesión, juntamente con la segunda, constituye un taller de lectura participativo y crítico.

Como acabamos de indicar, la estructura de la segunda sesión es similar a la de la primera, pero en este caso se realizan las lecturas de los fragmentos de las lecturas de los álbumes restantes. De nuevo, se hace especial hincapié en las protagonistas de las historias, en sus conflictos personales y con la sociedad, en sus características y en cómo se relacionan con el resto de personajes. De este modo, el debate posterior se centra en dichos personajes, donde la Luna también tiene un rol importante.

Para finalizar con estas dos sesiones, ofrecemos una batería con algunas posibles preguntas para iniciar los correspondientes debates, pero también se invitará al alumnado a que formule sus propias propuestas:

- What do you know about the moon?

- What do you like the most about Margaret Hamilton/the Hidden Figures?

- Would you like to catch the moon like Marcenia?

- What do you think about having a golden ladder to visit your grandma and grandpa?

- Do you think baseball is a male game? Why/why not?

- What are the best characteristics to get a good job?

- Why must girls and boys work together to have a better world? ${ }^{15}$

En cuanto a la sesión final, proponemos una actividad grupal titulada: Las heroínas de la Luna /Moon heroines donde, por grupos, tendrán que seleccionar la protagonista que más les haya gustado y mostrar la relación que esta tiene con la Luna a través de un poema, carta, dibujo, campaña publicitaria... Debido al carácter ecléctico y multidisciplinar de la sesión, se permite que escojan de qué manera se sienten más cómodos de mostrar dicha relación.

En suma, a través de las distintas sesiones, consideramos que se pueden conseguir los objetivos detallados anteriormente y, sobre todo, dar voz a las figuras femeninas eclipsa-

\footnotetext{
${ }^{15}$ ¿Qué sabes sobre la Luna? ¿Qué es lo que más te gusta de Margaret Hamilton/Las Figuras ocultas? ¿Te gustaría capturar la Luna como Marcenia? ¿Qué te parecería tener una escalera dorada para visitar a tu abuelo y a tu abuela? ¿Crees que el béisbol es un deporte de chicos? ¿Por qué/por qué no? ¿Cuáles son las principales características para conseguir un buen empleo? ¿Por qué deben las niñas y los niños trabajar juntos para lograr un mundo mejor?
} 
das y que componen la otra cara de la Luna. Del mismo modo, en las sesiones aquí presentadas los discentes aprenden aspectos relevantes de varios campos del conocimiento, entre ellos: la ciencia, la tecnología, la lengua, la literatura, la cultura y la historia. Por tanto, propuestas didácticas como la que presentamos aquí se hacen necesarias para una educación literaria intercultural y feminista, libre de sesgos de índole étnica y sexista.

\subsection{Conclusiones y consideraciones finales}

En los albores de los primeros decenios del siglo XXI consideramos pertinente y necesario el fomento de una educación literaria intercultural y feminista donde la Otredad femenina y/o la atribuida a las tradicionalmente consideradas minorías no se muestren relegadas ni denostadas. Con este objetivo, hemos introducido el capítulo con un apartado histórico donde se puede ver el rol femenino en la denominada llegada a la otra cara de la Luna. Seguidamente, nos centramos en la educación literaria, el feminismo y la interculturalidad como ejes de un proceso educativo crítico y librepensador que promueve la imaginación, la curiosidad y el pensamiento crítico entre los discentes. A continuación, después de describir los beneficios del álbum ilustrado como soporte idóneo en este tipo de educación, se procedió al análisis de los distintos materiales, teniendo en cuenta la doble simbología de la Luna como astro físico y como ente imaginario y romántico. Finalmente, se diseñaron una serie de sesiones con sus respectivas actividades cuyo objetivo primordial fue la visibilidad del papel de la mujer en la llegada a la Luna y la posterior crítica constructiva a través del debate y una actividad grupal que englobaba diversas disciplinas.

Por tanto, la ciencia y la mujer no deben mostrarse por separado, aunque tradicionalmente así se haya hecho, como expresa de manera muy sugestiva Escribano (2010, pág. 151):

\footnotetext{
La historia de la ciencia que nos han contado está llena de nombres masculinos: Newton, Einstein, Franklin, Graham Bell... Hay datos sobre la figura y aportaciones de algunas mujeres, en especial de Madame Curie. Pero, ¿hay otras mujeres científicas? A una/ un profana/o en la materia podría parecerle que no, que las mujeres solo tienen un contacto con la ciencia en tanto que usuarias de sus descubrimientos, por ejemplo, de la lejía.
}

Afortunadamente, propuestas como las que presentamos en este capítulo intentan que, poco a poco, las mujeres científicas sean (re)conocidas, valoradas y que ocupen el lugar que merecen en la historia de la ciencia. A través de historias como las de las mujeres de la otra cara de la Luna, se pueden abrir nuevas perspectivas más plurales, feministas y más justas, donde la igualdad de género sea una realidad tangible en el siglo XXI.

\subsection{Referencias bibliográficas}

Aguado, T. (2003). Pedagogía intercultural. México: McGraw-Hill.

Ballester, J. (2007). L'educació literària. València: Universitat de València.

Bloom, H. (1995). El canon occidental: la escuela y los libros de todas las épocas. Barcelona: Anagrama. 
Campbell, J. (2018). Franklin and Luna go to the moon. London: Thames \& Hudson.

Cicerchia, R. (1999). Alianzas, redes y estrategias: El encanto y la crisis de las formas familiares. Revista Nómadas, 11, 46-53.

Comenius, J. A., Hoole, C., e In Bardeen, C. W. (1968). The Orbis pictus of John Amos Comenius. Detroit: Singing Tree Press.

Corbyn, Z. (2019). Margaret Hamilton: 'They worried that the men might rebel. They didn't', The Guardian. Recuperado de: https://www.theguardian.com/technology/2019/jul/13/margaret-hamilton-computer-scientist-interview-software-apollomissions-1969-moon-landing-nasa-women. Consultado el 24 de julio de 2019.

Domene, R. (2019). Aragonesas con voz propia. Teruel: Terueligráfica.

Dueñas, J.D. (2013). La educación literaria. Revisión teórica y perspectivas de futuro. Didáctica. Lengua y Literatura, 25, 135-156.

Escribano, P. (2010). Mujeres en, por y para la ciencia. Dossiers Feministes, 14,151-174.

García, B. (2005). Las mujeres a través de la historia. Trabajo silenciado. En Mujer, fuerzas armadas y conflictos bélicos. Una visión panorámica. Ministerio de Defensa, Instituto Español de Estudios Estratégicos.

Hoster Cabo, B., y Gómez Camacho, A. (2013). Interpretación de álbumes ilustrados como recurso educativo para la competencia literaria y visual. Red Visual, 19, $65-76$.

Hubbard, C. (2005). Catching the moon: The story of a young girl's baseball dream. New York: Lee \& Low Books.

Magallón, C. (2017). Science from women's lives. Better Science? How gendered studies improve science and lives, Mètode Science Studies Journal, 7, 105-111.

Martel de la Coba, M. C. (2005). Los feminismos, la educación y yo, Revista Qurriculum, 18, 9-37.

Massey, R., \& Loske, A. (2018). Luna: Arte, ciencia, cultura. Madrid: Akal.

Mendoza, A. (2001). El intertexto lector. Ediciones de la Universidad de Castilla-La Mancha: Cuenca.

Nodelman, P. (1988). Words about pictures: The narrative art of children's picture books. Athens: University of Georgia Press.

Noragueda, C. (2017). 'Hidden Figures', tres mujeres fundamentales de la NASA, Hipertextual. Recuperado de: https://hipertextual.com/2017/01/hidden-figureskatherine-johnson-dorothy-vaughan-mary-jackson. Consultado el 24 de julio de 2019.

Paz, O. (1956). El arco y la lira: el poema; la revelación poética; poesía e historia. México: Fondo de Cultura Económica.

Pueyo, J. (2018). "Pensé más en que el programa funcionó que en la llegada a la Luna", El País. Recuperado de: https://elpais.com/tecnologia/2018/10/22/actualidad/1540207046 513939.html Consultado el 24 de julio de 2019. 
Robbins, D. (2017). Margaret and the Moon. USA: ALFRED A KNOPF.

Roché, M. (2015). Developing children's critical thinking through picturebooks: A guide for primary and early years students and teachers. Milton Park, Abingdon, Oxon: New York, NY: Routledge.

Roettiger, L. (2019). Aliana reaches for the moon. Lemont, PA: Eifrig Publishing

Rosenblatt, L. M. (1978). The reader, the text, the poem: The transactional theory of the literary work. Carbondale: Southern Illinois University Press.

Sánchez, A., Samper-Gras, T., Jabbaz. M. y Diaz, C. (2017). An open path for gender equality in research: When women scientists question the state of science and the institutions embrace the criticism, Mètode Science Studies Journal, 7, 97-103.

Sartre, J. P. (1943). L'Être et le néant. Paris: Gallimard.

Sau, V. (2000). Reflexiones feministas para principios de un siglo. Madrid: Horas y horas.

Shetterly, M. L. (2016). Hidden Figures: The American Dream and the Untold Story of the Black Women Mathematicians Who Helped Win the Space Race. New York, NY: William Morrow.

Soetoro-Ng, M. (2011). Ladder to the moon. Somerville, Mass: Candlewick Press. 


\section{Capítulo 7 \\ Proyecto Girls4STEM: fomento de vocaciones científico-tecnológicas desde la igualdad y la diversidad}

Silvia Rueda ${ }^{1}$, Emilia López-Iñesta ${ }^{2}$, Carmen Botella-Mascarell ${ }^{1}$, Joaquin Perez $^{3}$, Esther de Ves ${ }^{1}$, Xaro Benavent ${ }^{1}$, Anabel Forte4 Esther Dura1, Sandra Roger1, Cristina Portalés1, Daniel Garcia-Costa1y Paula Marzal5

1Depto. de Informática 2Depto. de Didáctica de la Matemática 3Depto. de Ingeniería Electrónica 4Depto. de Estadística e Investigación Operativa 5Depto. de Ingeniería Química Universitat de València

\subsection{Introducción}

El uso cada vez más extendido de las Tecnologías de la Información y de la Comunicación (TIC) en nuestras actividades cotidianas está generando una demanda creciente de personal cualificado en las denominadas profesiones CTIM (Ciencias, Tecnología, Ingeniería y Matemáticas), también conocidas por sus siglas en inglés como STEM. De hecho, informes como The Future of Jobs Report (World Economic Forum, 2018) señalan que la Cuarta Revolución Industrial, caracterizada por el avance tecnológico, creará oportunidades completamente nuevas en el mercado laboral STEM. Asimismo, la encuesta realizada en 2019 por la patronal de empresas tecnológicas DigitalES ${ }^{16}$ indica que existen al menos 10 mil empleos vacantes no cubiertos en el sector tecnológico en España por falta de cualificación, y se calcula que entre 2017 y 2022 se crearán más de 1 millón de empleos en España.

Esta situación, sin embargo, contrasta con la escasez de vocaciones en las áreas STEM entre el futuro estudiantado, especialmente en el área de las TIC. En concreto, la tenden-

${ }^{16} \mathrm{https}: / / w w w . d i g i t a l e s . e s / ? \mathrm{~s}=10000+$ vacantes 
cia de los datos del Ministerio de Educación, Cultura y Deporte muestra un descenso en el número de personas matriculadas en carreras técnicas, como Ingenierías y Arquitectura, un $28 \%$ en los últimos años (López-Iñesta, Botella, Rueda, Forte y Marzal, 2020). Esta situación representa un problema desde hace tiempo, como advertía el Informe Rocard de 2007, con repercusiones tanto a corto como a largo plazo ya que, además de no disponer de suficientes profesionales para llegar a cubrir los puestos de trabajo en el área, surgen desigualdades y desequilibrios que difícilmente podrán revertirse en los próximos años sin unos planes de acción adecuados (Rocard et al., 2007).

Al problema de esta falta de vocaciones STEM en la sociedad, se añade la baja proporción de mujeres que cursan carreras en estas ramas (iClaves y European Commission, 2018). En el caso particular de los estudios de Ingeniería Informática, el porcentaje de mujeres ha pasado de un 30\% en el curso 1985-1986 a un 13\% en el curso 2017-2018 (Merelo y Merelo, 2017). Por otro lado, un alto porcentaje de mujeres egresadas en STEM renuncian a su puesto de trabajo a lo largo de su carrera profesional debido a las dificultades para conciliar trabajo y familia (Cech y Blair-Loy, 2019).

Esta situación pone de manifiesto la progresiva pérdida del talento, visión y aportaciones de la mitad de la población que ocurre desde hace años en los sectores TIC-STEM, hecho que debería llamar la atención ya que existen evidencias que muestran que la diversidad de género y, en general, la composición de equipos de trabajo diversos e interdisciplinares es fundamental tanto para la mejora de la investigación como para la innovación (Turban, Wu y Zhang, 2019; Hunt, Prince, Dixon-Fyle y Dolan, 2020). Además, se ha demostrado que una mayor participación de las mujeres, no solo en los campos STEM, tiene un impacto muy positivo en la economía global (Duflo, 2012).

A la luz de estas consideraciones, en los últimos años han surgido múltiples iniciativas desde instituciones públicas y privadas para fomentar el interés por la ciencia y las disciplinas STEM en niños y especialmente en niñas desde edades tempranas (Botella, Rueda, López-Iñesta y Marzal, 2019). La necesidad queda demostrada por estudios como los de Bian, Leslie y Cimpian (2017), que muestran que las niñas empiezan a carecer de confianza en sus habilidades y perder interés en las materias STEM a partir de los 6 años. Por ello, es muy importante involucrar al sistema educativo desde la etapa de la educación primaria y secundaria en la búsqueda de soluciones a este problema tratando, además, de eliminar los estereotipos existentes sobre las profesiones STEM, tal y como señala el Libro Blanco de las mujeres en el ámbito tecnológico (Mateos y Gómez, 2019). Por otro lado, para que las niñas se sientan identificadas y se imaginen desarrollando esos trabajos en su futuro laboral, es necesario que vean modelos y referentes femeninos en los que puedan verse reflejadas (UNESCO, 2017).

En el ámbito universitario, el análisis de las estadísticas refleja una feminización en las áreas de la salud y educación y una masculinización en aquellos estudios directamente relacionados con las ingenierías y la tecnología. Esto ocurre tanto en el número de estudiantes como en el personal docente e investigador (PDI). El Libro Blanco. Situación de las Mujeres en la Ciencia Española de Sánchez de Madariaga, de la Rica y Dolado 
(2011) evidenciaba ya en 2011 un sesgo en la evaluación del mérito en la promoción a la carrera académica en España. Por ello, las universidades, a través las unidades de igualdad y los planes de igualdad, trabajan para superar los sesgos y los estereotipos establecidos, ya que las mujeres aún están poco representadas en cuestiones relativas a la excelencia, puestos de responsabilidad o premios, a pesar de haber una mayoría de estudiantes mujeres en las universidades.

Por los motivos anteriormente expuestos, las iniciativas que tienen por objeto visibilizar, premiar e incentivar los referentes femeninos en un entorno diverso e inclusivo son, sin duda, apuestas clave para atraer y retener al talento femenino. Con este ambicioso objetivo surgió la idea de crear e impulsar el proyecto Girls4STEM ${ }^{17}$ en la Universitat de València que se expone en las siguientes secciones, detallando su origen y las líneas de actuación, además de presentar las acciones y actividades realizadas hasta el momento y el futuro del proyecto.

\subsection{Origen de Girls4STEM: programa piloto de la ETSE-UV}

Las instituciones de educación superior pueden desarrollar un papel fundamental en el ecosistema de factores que afectan a las decisiones formativas y vocacionales de las personas, contribuyendo a la promoción de las vocaciones STEM, especialmente entre las niñas. Sin embargo, para ello se deben de tener en cuenta las conclusiones de trabajos como los de Weisgram y Bigler (2006), que señalan que hay variables como el impacto social, vinculado al cuidado de las personas y a las relaciones interpersonales, así como valores como el altruismo, que afectan a las decisiones profesionales de las niñas, haciendo que desde edades tempranas excluyan las carreras de la rama de ingeniería en sus decisiones por considerarse 'masculinas'. Por ello, es necesario que las instituciones de educación superior asuman su responsabilidad y contribuyan a la difusión de la aplicabilidad con fines sociales de las áreas STEM, mostrando una correspondencia entre estas disciplinas y la mejora de la sociedad.

Desde un punto de vista práctico, la educación superior necesita reforzar la interacción con el estudiantado preuniversitario, pero también con el resto de las esferas de influencia de este, como son las constituidas por familia y profesorado o educadores. De forma más específica, es posible destacar tres dimensiones básicas de actuación en el estudio de Botella et al. (2019), como son:

\footnotetext{
${ }^{17}$ Agradecimientos: Este trabajo ha sido financiado por los proyectos FCT-18-13147 de la FECYT, RTI2018-095820-B-I00 del Ministerio de Ciencia e Innovación, la Agencia Estatal de Investigación (AEI) y el Fondo Europeo de Desarrollo Regional (FEDER), MTM2016-77501-P del Ministerio de Economía y Competitividad español, así como las becas Ramón y Cajal RYC-2017-22101 y RYC2018-025009 y los proyectos UV-SFPIE-PID19-1097673, UV-SFPIE-PID19-1097874, UV-SFPIEPID19-1098335 del SFPIE de la Universitat de València (UV). Agradecemos también a Capgemini, Singularity Experts y todas las empresas patrocinadoras del proyecto, el Vicerectorat d'Igualtat, Diversitat i Sostenibilitat (UV), la Unitat d'igualtat (UV), la Unidad de Cultura e Innovación Científica (UV), el CEFIRE CTEM y los centros escolares participantes, las expertas STEM, el personal de la ETSE-UV, y otras entidades y facultades de la Universitat de València.
} 
i) interactuar con las familias y/o educadores, centros de educación secundaria y otros agentes equivalentes para conseguir programas inclusivos y diversos que faciliten un proceso de enseñanza-aprendizaje de calidad en la infancia;

ii) proporcionar apoyo a aquellas estudiantes que ya han accedido a estudios englobados en las disciplinas STEM-TIC mediante el desarrollo de acciones complementarias o extracurriculares; $y$

iii) colaborar con las estudiantes graduadas de sus centros para construir redes de apoyo profesional.

La Escola Tècnica Superior d'Enginyeria de la Universitat de València (ETSE-UV) es el centro responsable de los estudios de la rama de Ingeniería y de la Ciencia de Datos impartidos en la Universitat de València. Este centro viene desarrollando desde el año 2011 un programa piloto estructurado en torno a las tres dimensiones mencionadas anteriormente. De hecho, como institución que cubre los niveles de grado, máster y doctorado, puede abordar el problema de la diversidad de género principalmente en dos áreas diferenciadas. Por un lado, promoviendo la interacción con los centros de educación secundaria (estableciendo modelos femeninos a seguir que contribuyan a romper con los estereotipos) y segundo, motivando y creando redes de apoyo entre las estudiantes que acceden a sus estudios. Un componente esencial y transversal del programa piloto de la ETSE-UV es la difusión y la visibilidad dada a las disciplinas STEM como fundamentales para lograr un objetivo comunitario.

En este sentido, se puede señalar que la ETSE-UV es una institución que, a través del programa piloto, ha contribuido a concienciar en su entorno de influencia sobre el problema de la necesidad de entornos diversos en género en STEM, formando parte de las iniciativas que permitirán una transición hacia una cultura o sociedad sensible al género y a la diversidad en general. Tal y como indica la UNESCO (2017), en el caso particular de los campos STEM es fundamental promover la presencia de más modelos femeninos, y esto se puede articular aumentando la presencia de mujeres tanto entre el alumnado como entre el profesorado o en el entorno profesional. Sin embargo, los planes de igualdad o las acciones afirmativas deben planificarse en una escala temporal a largo plazo y siempre incluyendo criterios construidos sobre la base de calificaciones y méritos. De hecho, en el caso de las mujeres profesionales, se les puede atribuir el estigma de la incompetencia si se benefician de acciones de discriminación positiva (Heilman, Block y Lucas, 1992), mientras que, en el caso de las alumnas, la integración de los estudiantes hombres es fundamental para evitar sentimientos de frustración y que no perciban que las mujeres tienen acceso a recursos exclusivos (Smith y Gayles, 2018).

Con el objetivo, entonces, de conseguir un ambiente de estudio y trabajo acogedor y de apoyo a las mujeres, el programa piloto de la ETSE-UV se alinea con algunas propuestas del informe Cracking the code: girls' and women's education in Science, Technology, Engineering and Mathematics (STEM) (UNESCO, 2017), destacando la promoción de la participación extracurricular de las estudiantes, las acciones de tipo tutorial y la visi- 
bilización de modelos femeninos a seguir en distintos ámbitos, tanto académicos como profesionales. De forma más específica, como se ha señalado antes, el programa piloto de la ETSE-UV interacciona con centros de educación secundaria, y motiva a sus estudiantes y colabora con las egresadas abarcando tres momentos vitales distintos en la formación del alumnado. Para llevar a cabo el programa, se diseñaron cuatro acciones fundamentales en el mismo, tal y como indican Botella et al. (2019) y se puede ver en la Figura 1, que consisten en:

i) proporcionar estímulo institucional y apoyo a las estudiantes;

ii) aumentar la red de apoyo profesional tras la graduación;

iii) promover y apoyar el liderazgo del personal académico; y

iv) aumentar la visibilidad de los modelos femeninos.

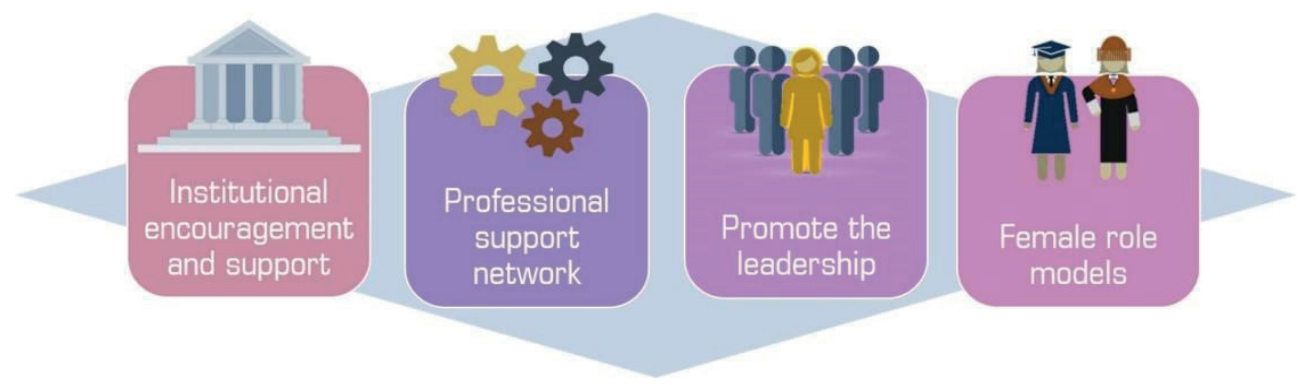

Fuente: Botella et al. (2019)

Figura 1. Acciones principales de la ETSE-UV para actuar ante el problema de diversidad de género.

Estas cuatro acciones se han desarrollado a través de varias actividades, tanto en las instalaciones de la ETSE-UV como fuera de la escuela, con distintas escalas temporales e implicando a diversos agentes según el objetivo de la actividad. Se puede encontrar una descripción detallada de las actividades, así como una justificación a partir del estado del arte en la cuestión de la diversidad de género y un análisis previo de los resultados en la ventana temporal 2011-2018, en los trabajos de Botella et al. (2019) y Rueda, Botella, López-Iñesta y Marzal (2019). En dichos estudios se demuestra que, por ejemplo, ha aumentado el porcentaje de estudiantes femeninas matriculadas en títulos relacionados con la Ingeniería Informática, situándose siete puntos por encima del promedio nacional español (Rueda et al., 2019).

Como se observa, el programa piloto de la ETSE-UV contemplaba la interacción con estudiantes de educación secundaria, pero, tal y como se ha presentado en la sección anterior, es necesario intentar llegar al alumnado comprendido en el intervalo de edad de entre los 6 y los 18 años. En este caso, por las características particulares de este público meta (por ejemplo, la necesidad del acompañamiento de sus familias y/o educadores 
en los asistentes de menor edad), una opción es la organización de actividades de tipo divulgativo que destaquen la presencia de mujeres en el sector STEM. En este ámbito concreto ya hay programas centrados en las niñas que evalúan el impacto que tiene la actitud hacia la ciencia en función de la edad (Fernández y Solano, 2017). Además, con el objetivo de llegar a la esfera de influencia del alumnado, primer punto de entrada de los estereotipos, las actividades de divulgación necesitarían garantizar la participación de las familias, educadores y educadoras, profesorado, e incluso entidades profesionales del ámbito STEM. Estas últimas serían las que podrían dar visibilidad a los avances sociales conseguidos gracias a las disciplinas STEM.

Cabe señalar que existen investigaciones sobre los beneficios e impacto conseguido por este tipo de actividades. De hecho, estudios como el de la Fundación La Caixa, FECYT y Everis (2015) indican que estas actividades tienen mucho menos impacto en las niñas, especialmente en el campo de la Ingeniería. Asimismo, trabajos como los de Kitchen, Sonnert y Sadler (2018) muestran que las actividades de divulgación pueden llegar a aumentar hasta un $1.8 \%$ las posibilidades de que el estudiantado se matricule en un título STEM.

Teniendo en cuenta estos aspectos, dentro del grupo de trabajo relacionado con el programa piloto de la ETSE-UV se planteó la necesidad de llegar a niñas más jóvenes (en etapas inferiores a la enseñanza secundaria) y de reforzar la interacción con el ecosistema que las rodea (familias, escuela, amistades). De esta forma, se empezó a gestar la iniciativa Girls4STEM desde principios de 2019 dentro de la ETSE-UV, que rápidamente fue adoptada por el Vicerectorat d'Igualtat, Diversitat i Sostenibilitat de la UV, al alinearse con las líneas estratégicas del III Pla d'Igualtat de la UV. Girls4STEM se presenta como proyecto, pero es, en realidad, una iniciativa paraguas que incluye todas las actividades y líneas de actuación de la ETSE-UV para concienciar sobre el problema de la falta de diversidad de género en las áreas STEM incluyendo, de esta forma, también las actividades realizadas dentro del programa piloto.

Como se ha comentado anteriormente, la evidencia disponible en estos momentos indica que las actividades de divulgación tienen un impacto menor en las niñas a menos que supongan una posibilidad real de que las niñas se imaginen y visualicen desempeñando tareas en el ámbito laboral. En paralelo, Diekman, Clark y Belanger (2019) han propuesto recientemente un marco para extraer elementos comunes en las distintas teorías psicológicas que tratan de inferir conocimiento al respecto de la brecha de género en STEM. De esta forma, en su trabajo se plantea un modelo con tres acciones básicas (desafiar los estereotipos, alinearse con valores y promover el desarrollo de actitudes) y se definen dos líneas de intervención, siendo una de ellas la piedra angular de Girls4STEM: la organización de actividades con oradores de un amplio espectro de perfiles e identidades STEM.

En la siguiente sección se describen los objetivos del proyecto y sus dos ejes fundamentales: las charlas FAMILY y las PROFESSIONAL. 


\subsection{El proyecto G4STEM}

El proyecto Girls4STEM tiene como principal objetivo el fomento de las vocaciones científico-tecnológicas en las áreas STEM para el alumnado preuniversitario con edades comprendidas entre los 6 y los 18 años. Se trata de una iniciativa integradora e inclusiva, que busca hacer especial hincapié entre las niñas y las chicas adolescentes, para intentar aumentar la baja representación femenina en estas disciplinas a la vez que mejorar su autoconfianza (Rittmayer y Beier, 2009), ya que como se ha mencionado en las secciones anteriores, es en estas etapas donde es necesario mostrar la conexión de las profesiones STEM con los beneficios para la sociedad (por ejemplo, el desarrollo de prótesis a través de la Ingeniería Informática, Electrónica o la Robótica para personas que han tenido un accidente) lo que puede potenciar el interés en la adquisición y el desarrollo de habilidades STEM como la programación para que la prótesis sea funcional. Para ello, siguiendo las directrices de estudios como el de la UNESCO (2017), es esencial buscar y crear referentes femeninos de proximidad que resulten atractivos al estudiantado femenino, que den visibilidad al papel de las mujeres en STEM, dando a conocer a qué dedican su día a día, mediante actividades divulgativas y de ocio.

Girls4STEM es una iniciativa que se encuentra enmarcada dentro de los Objetivos de Desarrollo Sostenible ${ }^{18}$ (ODS) establecidos por las Naciones Unidas en la Agenda de Desarrollo Sostenible para 2030 y supone beneficios tanto para el alumnado como para el profesorado y la sociedad en general. El proyecto se enmarca en los objetivos cuarto, quinto y décimo (ODS 4, ODS 5 y ODS 10), que tratan de garantizar una educación de calidad, la igualdad de género y la reducción de las desigualdades.

Por todo ello, los objetivos particulares que se persiguen con la iniciativa Girls4STEM consisten en:

1. Aumentar el número de estudiantes que deciden cursar estudios en áreas STEM, incidiendo especialmente en el número de chicas.

2. Despertar la curiosidad sobre las temáticas STEM desde edades tempranas.

3. Incentivar la participación de todas las partes implicadas: estudiantado, profesorado, familias, colegios profesionales y empresas haciéndoles sentir parte fundamental del proyecto.

4. Visibilizar a mujeres que desarrollan su labor profesional en áreas STEM y mostrar sus investigaciones, desarrollos y avances (estas profesionales son las denominadas "expertas STEM" que colaboran en el proyecto).

Una de las principales actividades programadas dentro del proyecto orientada al estudiantado preuniversitario (primaria, secundaria, bachillerato y ciclos formativos) son las charlas Girls4STEM FAMILY, en las que participan conjuntamente el alumnado, el profesorado, las expertas STEM y las familias. El objetivo de esta actividad es que el alum-

\footnotetext{
${ }^{18}$ https://en.unesco.org/sdgs
} 
nado conozca el día a día de una mujer profesional STEM, en qué consiste su trabajo, qué ventajas profesionales y personales le ha aportado y qué camino ha seguido. De esta manera, el estudiantado puede descubrir en ellas un referente a seguir, despertando la curiosidad por profesiones o facetas laborales que muchas veces son desconocidas para una gran parte del alumnado o, incluso, de la sociedad.

Para participar en el proyecto, en primer lugar, los centros educativos preuniversitarios deben elegir una experta STEM por curso o cursos, siendo limitado el número a cuatro expertas por centro. Para ello, en la página web de Girls4STEM ${ }^{19}$ se muestra un listado de las expertas que colaboran en el proyecto, indicando su área STEM específica y una pequeña biografía que ellas mismas han introducido. La elección de la experta se coordina entre el centro y el equipo organizador de Girls4STEM. El alumnado puede interactuar con la experta de varias maneras: visitando su lugar de trabajo, a través de una videoconferencia o reuniéndose con la experta en su centro de enseñanza primaria o secundaria.

A partir de los apuntes tomados en la visita o entrevista realizada a la experta, el alumnado ha de preparar un vídeo de menos de tres minutos sobre la experta, que se presentará posteriormente en una fecha concreta en un evento en el que tienen lugar las charlas $F A$ $M I L Y$. Estas charlas se celebran un sábado por la mañana en el Jardí Botànic de la Universitat de València, en un entorno natural y lúdico, en el que se ofrecen horchata y fartons y otros artículos de regalo cortesía de las empresas patrocinadoras de Girls4STEM. $\mathrm{Al}$ evento asiste el alumnado con sus familias, el profesorado y cuatro expertas STEM de las que se mostrarán los vídeos.

En cada charla FAMILY participan dos centros escolares, mostrando los vídeos que han elaborado sobre la experta entrevistada. En cada charla se presentan hasta ocho vídeos. A continuación, tras la visualización del vídeo, el profesorado, el alumnado, y la experta comparten sus experiencias con el público, comentando cómo han cambiado sus impresiones sobre las ramas STEM. Las expertas también pueden comentar a las familias interesadas algunas claves que les pueden ayudar a despertar el interés por las disciplinas STEM. Además de subir los vídeos al canal de YouTube del proyecto, se contempla la opción de redactar un resumen de las biografías de cada experta para la Wikipedia, en la medida que las restricciones de inserción de información en Wikipedia lo permitan. En la primera edición, de 2019-2020, del proyecto, se programaron cinco charlas FAMILY entre el mes de enero y el mes de junio de 2020. Desafortunadamente, a partir del mes de marzo, las charlas se debieron aplazar, debido a la pandemia de la COVID-19, al último trimestre del año 2020, y pasaron a celebrarse en una modalidad virtual (o híbrida) para preservar la seguridad de todas y todos los participantes.

La segunda actividad propuesta en el proyecto consiste en las charlas Girls4STEM PROFESSIONAL, orientadas al profesorado, alumnado de secundaria de últimos cursos y público general mayor de 16 años. Estas charlas tienen como objetivo principal presentar el

\footnotetext{
$\overline{19} \underline{\mathrm{http}: / / \text { girls } 4 \text { stem.es }}$
} 
proyecto al profesorado de los centros no universitarios, que resulta una pieza clave para fomentar la participación del estudiantado preuniversitario, pero también a estudiantes, empresas y público interesado.

En cada una de las charlas PROFESSIONAL, cuatro expertas STEM, de forma dinámica y a través de charlas entretenidas, dan a conocer el talento emergente dentro y fuera de la Comunidad Valenciana y ayudan a visibilizar el papel de las mujeres dentro de las disciplinas STEM, sirviendo de inspiración a todo el público en general y al profesorado en particular, para que pueda transmitir esta curiosidad por las disciplinas STEM a su alumnado.

La temática de la charla debe estar relacionada directamente con la actividad profesional y experiencia personal en los sectores STEM y debe ajustarse a una duración máxima de 10 minutos. Se pretende, así, dar a conocer el lado más humano y menos conocido de las profesiones del ámbito STEM. Las charlas se realizan en un ambiente distendido, pretenden ser un lugar de encuentro con una duración aproximada de una hora y cuarto como máximo para permitir la conciliación laboral y familiar. En ellas se ofrece a las personas asistentes un refresco y/o agua y un aperitivo, por cortesía de las empresas patrocinadoras del proyecto.

Las charlas PROFESSIONAL se celebran los jueves por la tarde, como un plan de ocio alternativo, en espacios emblemáticos de la Universitat de València, contribuyendo a potenciar la relación de la propia Universitat de València con la sociedad valenciana y dando conocer su historia. El equipo de expertas STEM está formado por mujeres profesionales que, de forma altruista, quieren colaborar con esta iniciativa para generar más referentes femeninos STEM y difundir estas profesiones entre los niños y niñas.

La tercera actividad propuesta es una actividad de formación orientada al profesorado de primaria y secundaria que participa en las charlas FAMILY. Se trata de una sesión de 2 horas de duración en la que se proporciona al profesorado una guía de lo que debe hacer para coordinar un grupo de estudiantes y cuáles son los objetivos contemplados en Girls4STEM. Esta sesión se repite en dos fechas: en la edición de 2019-2020 la primera fecha fue en el mes de septiembre de 2019 y la segunda durante el mes de enero de 2020.

Para favorecer la participación del profesorado no universitario que, como ya se ha comentado, es clave para la realización del proyecto Girls4STEM, se cuenta con la colaboración del Centre de Formació, Innovació i Recursos per al professorat de Ciències, Tecnología, Enginyeria i Matemàtiques (CEFIRE CTEM). A través de este CEFIRE, la participación del profesorado se puede certificar, siendo reconocida como formación de prácticas, con tareas de documentación y estudio por parte del docente que equivalen a un total de 30 horas de formación. Para que le sean reconocidos los créditos, el profesorado de centros inscritos en el programa Girls4STEM deberá asistir a una sesión inicial de formación, a una Charla Girls4STEM PROFESSIONAL como mínimo, debe guiar y ayudar a un grupo de estudiantes en la elaboración del vídeo a presentar en una de las sesiones de charlas FAMILY (a la que también deberá asistir). 
La Figura 2 muestra un esquema de las actividades planificadas en el proyecto Girls4STEM, su implementación y las entidades o personas implicadas.

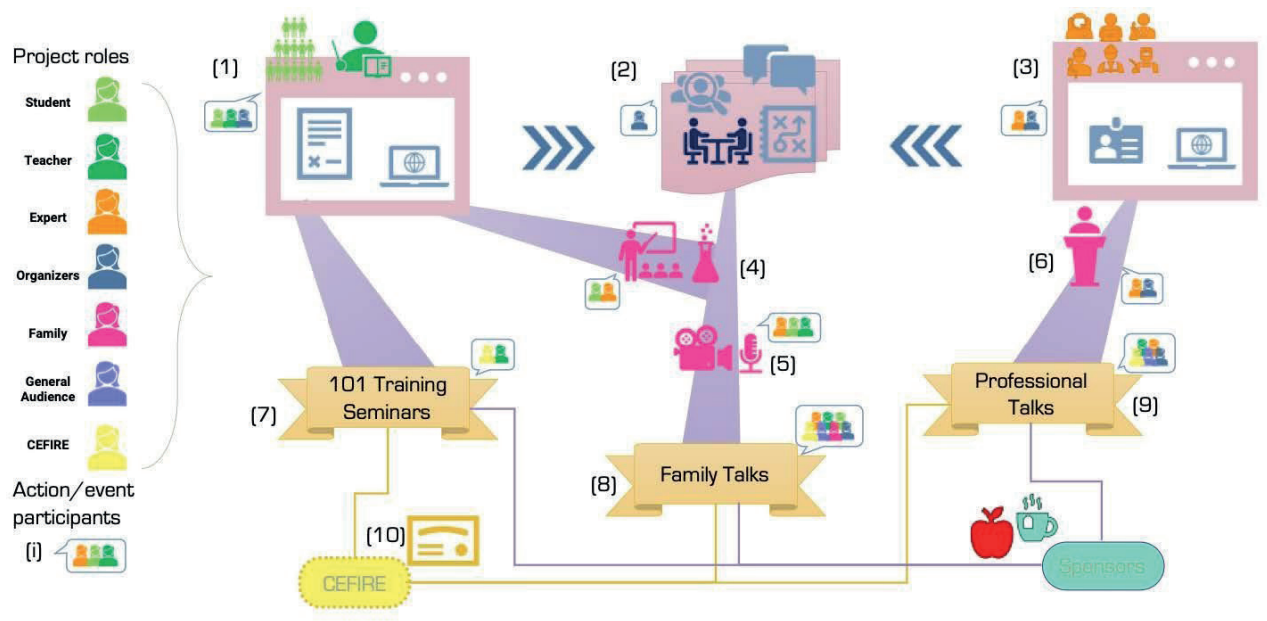

Fuente: Benavent et al. (2020)

Figura 2. Principales actividades diseñadas y roles de las y los participantes en el proyecto Girls4STEM: (1) Centros escolares; (2) Asignación de experta STEM al centro escolar; (3) Expertas STEM; (4) Reunión/encuentro estudiantes-experta; (5) Creación del vídeo; (6) Selección de las expertas para las charlas Professional; (7) Seminario de formación; (8) Charla FAMILY; (9) Charla PROFESSIONAL; and (10) CEFIRE CTEM.

Para conocer el impacto del proyecto, se han establecido mecanismos de inscripción y control de asistencia, los cuales permiten evaluar la ejecución del proyecto:

1. Formulario de inscripción para las charlas Girls4STEM PROFESSIONAL en el que se incluyen una serie de preguntas básicas relacionadas con conocimientos sobre las disciplinas STEM.

2. Encuesta en formato concurso mediante un programa de gamificación denominado Kahoot ${ }^{20}$ que permite medir el impacto y el interés de la actividad antes de finalizar la sesión Girls4STEM PROFESSIONAL. En este se incluyen preguntas sobre las charlas, siempre manteniendo el tono lúdico.

3. Formulario de inscripción para las Charlas Girls4STEM FAMILY, similar al de las charlas Girsl4STEM PROFESSIONAL.

4. Encuesta en formato concurso mediante Kahoot! con preguntas sobre los videos presentados y el interés de la actividad.

${ }^{20}$ https://kahoot.it/ 
5. Encuestas realizadas al alumnado, una previa y otra posterior, a la presentación del vídeo en una charla Girs4STEM FAMILY.

El proyecto Girls4STEM cuenta con el respaldo institucional de la Universitat de València a través de su Vicerectorat d'Igualtat, Diversitat i Sostenibilitat i la Unitat d'igualtat y la iniciativa se enmarca en las líneas estratégicas del Plan de Igualdad de la UV y es una de las acciones principales dentro de la Càtedra de Bretxa Digital de Gènere establecida en septiembre de 2020 mediante la firma de un convenio entre la Universitat de València i la Generalitat Valenciana, a través de la Conselleria d'Innovació, Universitats, Ciència i Societat Digital. Asimismo, Girls4STEM tiene financiación pública a través del Ministerio de Ciencia, Innovación y Universidades a través de un proyecto de la Fundación Española para la Ciencia y la Tecnología (FECYT). Por otro lado, el proyecto cuenta con el apoyo de la Secretaría Autonómica de Educación y el CEFIRE, lo que se traduce en una estrecha colaboración con centros educativos públicos, concertados y privados.

Otras instituciones vinculadas a la Universitat de València que también han brindado su apoyo son el Jardí Botànic, el Col·legi Major Rector Pesset, la Fundació Universitat Empresa (ADEIT), la Unitat de Cultura Científica i de la Innovació de la UV, el Vicerectorat d'Ocupació i Programes Formatius o UVemprèn.

En cuanto a otros colectivos que también se han implicado en el proyecto, cabe resaltar la participación de los colegios profesionales de ingeniería con los que se ha trabajado estrechamente desde la ETSE-UV, la Asociación de Mujeres Investigadoras y Tecnólogas (AMIT), la Asociación de Empresarios de Parques y Polígonos Industriales (Ribera Baixa) (APPI), y diferentes empresas del sector con las que la UV tiene firmadas cátedras o convenios de colaboración. Este es el caso de Capgemini, empresa que ha participado como desarrolladora de la web del proyecto.

Además, numerosas empresas privadas colaboran en esta iniciativa con su patrocinio: Batterfly, Capgemini, Singularity Experts, Mari Golosa, Malferida, Medita, Polo o Kitu. Estas empresas prestan sus productos y/o servicios en los eventos de las charlas FAMILY y PROFESSIONAL.

\subsection{Algunas cifras: ¿qué se ha hecho hasta ahora?}

Los números de la primera edición del proyecto son los siguientes: han participado 10 centros escolares, que han interactuado con 38 expertas. El alumnado participante se compone de 75 estudiantes de primaria, 311 de secundaria y 9 de formación profesional. El $56.7 \%$ del total de alumnado participante eran niñas o chicas.

A lo largo del curso académico 2019-2020, se planificaron 5 charlas profesionales, en las que colaboraban 4 expertas STEM por charla. En las 3 charlas profesionales desarrolladas hasta marzo de 2020, participaron 414 personas, de las cuales un $56 \%$ eran mujeres y un $33 \%$ estaban relacionadas profesionalmente con la educación. 
En el momento de redacción de este capítulo (septiembre de 2020), hay registradas 116 expertas en la base de datos del proyecto, número que aumenta debido a la expansión de la iniciativa.

El proyecto, como se ha indicado anteriormente, incluye un seminario de formación para profesorado de primaria y secundaria. En esta primera edición, han participado 40 profesores, de los cuales un $87 \%$ eran mujeres y un $83 \%$ eran docentes de enseñanza secundaria.

Otro dato importante es el impacto del proyecto en redes sociales. En julio de 2020, el proyecto cuenta con 1267 seguidores en Twitter, 400 en Instagram y 190 en Facebook.

Como ejemplo, se ha realizado una representación gráfica en la Figura 3 del análisis de los mensajes de Twitter de cara al seguimiento de la actividad de la charla PROFESSIO$N A L$ que tuvo lugar en diciembre de 2019. La figura muestra las etiquetas (hashtags) empleadas en los mensajes relacionados con el proyecto Girls4STEM. Las etiquetas \#estereotiposdegénero, \#MujeresEnCiencia, \#sostenibilidad, \#perspectivadegénero, \#referentesfemeninos, \#ingeniería, \#matemáticas, \#bioquímica, \#InferenciaBayesiana o \#ingenieríaindustrial dan una idea de las temáticas tratadas y los aspectos que se incluyen en el proyecto Girls4STEM.

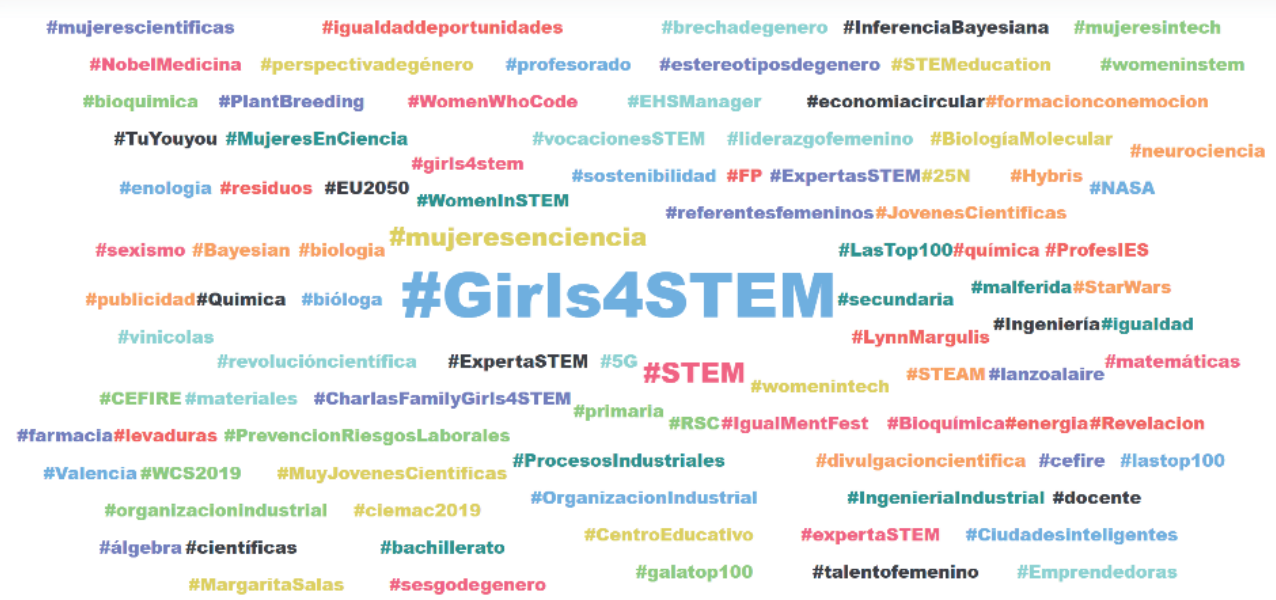

Fuente: elaboración propia

Figura 3. Análisis de los mensajes de la red social Twitter relacionados con la etiqueta \#Girls4STEM.

Empleando técnicas de visualización de datos, se pueden detectar las menciones que hacen a nuestro proyecto en Twitter con la etiqueta \#Girls4STEM, los retuits, y las subcomunidades que se definen a partir de la interacción de determinados perfiles con los que se relaciona el proyecto. 
En la Figura 4, se puede ver la red generada por las etiquetas o hashtags relacionados con \#Girls4STEM. Como se observa, se relacionan los ámbitos de educación primaria y secundaria que se recogen en el proyecto y se menciona al CEFIRE, colaborador imprescindible de este proyecto. Relacionados con \#Girls4STEM y como se ha indicado antes, se hace referencia a las \#CharlasFamilyGirls4STEM, \#expertasSTEM, \#ReferentesFemeninos y \#MujeresEnciencia. Otras etiquetas que se relacionan con el proyecto y son muy interesantes son \#WomenInTech, \#WomenWhoCode que, a su vez, se relacionan con \#formaciónConEmoción. Los colores de esta red indican la presencia de subcomunidades, y los diferentes colores indican qué subcomunidades están creándose teniendo como nodo central de la red @Girls4STEMVLC (perfil del proyecto en Twitter).

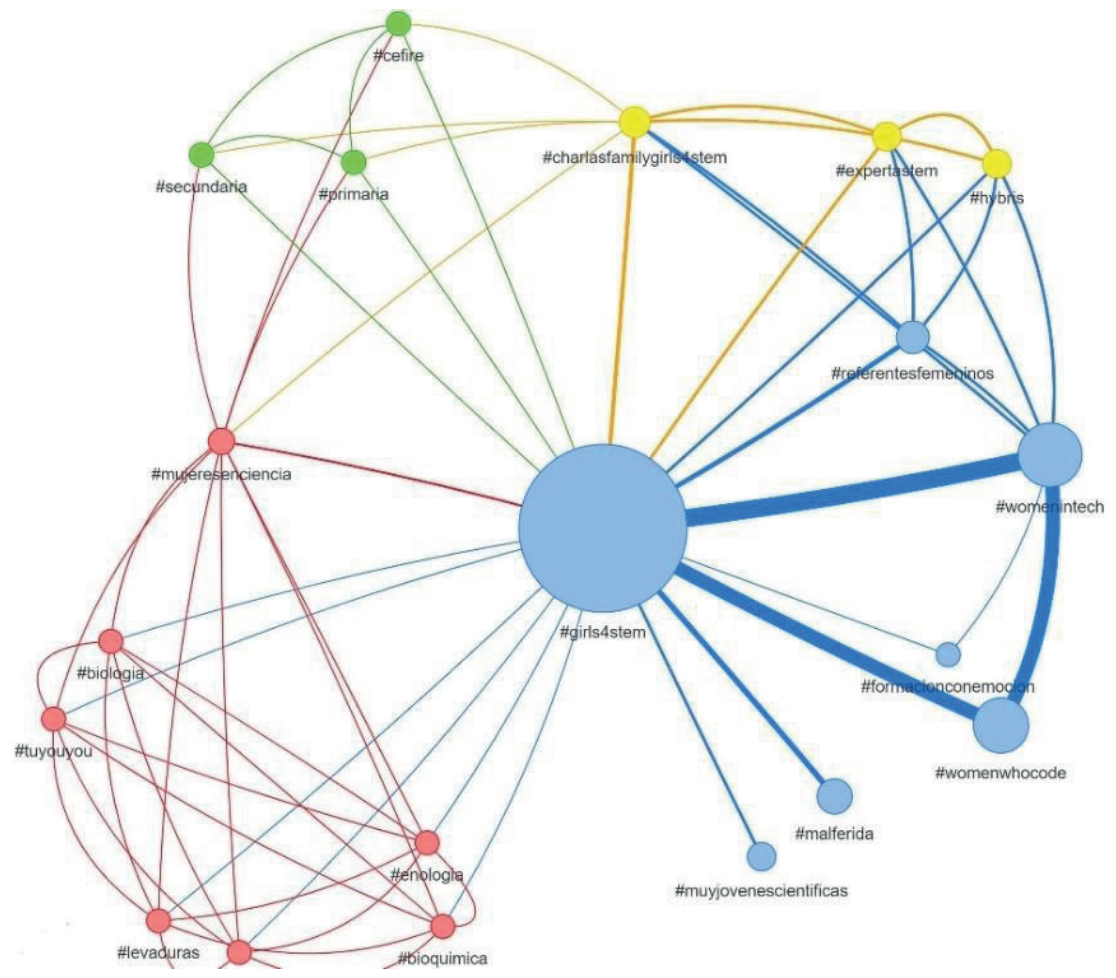

Fuente: elaboración propia

Figura 4. Redes generadas con nodo central la etiqueta \#Girls4STEM.

La colaboración estrecha con iniciativas como DatabeersVlc ${ }^{21}$, una iniciativa de charlas informales sobre ciencia de datos, resultó en la celebración de una sesión especial para conmemorar el 11 de febrero, día de la niña y la mujer en la ciencia, en la que las ponentes son mujeres. Esto es especialmente importante, pues se trata de un foro en el ámbito STEM en el que cuesta ver a mujeres como ponentes, ya que muchas de ellas admiten

${ }^{21}$ https://databeersvlc.com/ 
tener el "síndrome de la impostora". La iniciativa tiene lugar en toda España y podría ser muy interesante plantear extender la colaboración al resto de nodos de Databeers.

Uno de los aspectos que consideramos más diferenciadores del proyecto es el amplio abanico de público sobre el que incide el proyecto de manera directa. Cabe resaltar que esta iniciativa, además del impacto directo en cuanto a transferencia a la sociedad, ha tenido la capacidad de haber avanzado en el conocimiento científico mediante la publicación de artículos científicos en revistas indexadas y clasificadas como muy relevantes (Q2). Estas publicaciones despertarán previsiblemente el interés de la comunidad científica, por lo que el impacto del proyecto también es significativo en cuanto al avance del conocimiento en esta línea de investigación. Estos artículos y la presentación de trabajos en congresos permiten presentar evidencias contra el pensamiento común que establece que las niñas no acceden a las disciplinas STEM porque "no les gustan".

De esta manera, el método de evaluación, así como un mayor detalle de los resultados obtenidos en los cuestionarios mencionados en la sección 1.4 de este capítulo, se pueden consultar en los siguientes artículos de investigación elaborados por parte del equipo Girls4STEM, compuesto por mujeres y hombres:

López-Iñesta, E.; Botella, C.; Rueda, S.; Forte, A.; Marzal, P. (2020) Towards breaking the gender gap in Science, Technology, Engineering and Mathematics. IEEE Revista Iberoamericana de Tecnologías del Aprendizaje, 15(3), 233-241. doi:10.1109/RITA.2020.3008114

Benavent, X., de Ves, E., Forte, A., Botella-Mascarell, C., López-Iñesta, E., Rueda, S., Roger, S., Perez, J., Portalés, C., Dura, E., Garcia-Costa, D. y Marzal, P. (2020). Girls4STEM: Gender Diversity in STEM for a Sustainable Future. Sustainability, 12, 6051. https://doi.org/10.3390/su12156051

En este sentido, es importante remarcar que Girls4STEM es un proyecto que basa la puesta en marcha de sus acciones en evidencias científicas. Por ello, es fundamental estudiar y evaluar qué ocurre después de cada evento para planificar las siguientes actividades. A través de los datos recogidos, se realizan investigaciones que quedan plasmadas en distintos trabajos publicados en revistas como los que se han mencionado.

Los artículos exponen parte del impacto cuantitativo del proyecto y, en particular, el segundo trabajo presentado por Benavent et al. (2020) muestra resultados como la confirmación de una necesidad de mayor divulgación del término STEM y sus implicaciones, puesto que parte de los participantes no podían identificar correctamente qué disciplinas se englobaban dentro de este término. En el artículo también se pueden consultar las diferentes percepciones por parte de alumnado, profesorado y familias al respecto del desempeño del alumnado participante en diversas asignaturas de su currículum.

Se pueden consultar más trabajos del equipo de Girls4SInferenciaBayesiana, otras publicaciones y trabajos presentados en múltiples congresos y jornadas en el enlace https:// cutt.ly/WdNpYub. 
A través del uso que se ha realizado de las redes sociales, se ha generado mucho contenido que se puede emplear en distintos contextos. Por ejemplo, las fichas de ponentes y materiales para visualizar tanto las actividades del proyecto Girls4STEM como a las expertas STEM y el público participante. Se puede consultar todo el material en los canales sociales del proyecto de Facebook ${ }^{22}$, Twitter ${ }^{23}$ e Instagram ${ }^{24}$. Además, el canal de YouTube ${ }^{25}$ contiene los vídeos ya publicados de algunas expertas, así como los vídeos de presentación del proyecto ${ }^{26} \mathrm{o}$ divulgación y de otras actividades relacionadas.

\subsection{EI futuro del proyecto Girls4STEM}

Como se ha comentado a lo largo del capítulo, Girls4STEM es un proyecto de reciente creación que surge a partir de una iniciativa previa dirigida al estudiantado de la ETSEUV. El proyecto se plantea actualmente como un paraguas con el que abarcar todas las iniciativas de la Universitat de València relacionadas con la perspectiva de género en STEM dentro de las actuaciones y medidas que prevé el II Plan de Igualdad de la UV, organizado dentro de su Vicerectorat d'Igualtat, Diversitat i Sostenibilitat y en estrecha colaboración con la Unitat d'Igualtat. En este sentido, el proyecto Girls4STEM no sustituye al actual programa de la ETSE-UV, sino que lo complementa y amplía.

En cuanto a las actividades concretas planificadas a corto, medio y largo plazo, cabe resaltar el reciente cambio de escenario provocado por el estado de alarma que se decretó en nuestro país debido al virus COVID-19 y el consecuente confinamiento forzoso, situación que se repite en todos los países del mundo. Este hecho determinó que las actividades planificadas a partir de marzo de 2020 tuvieran que ser aplazadas, como se ha explicado anteriormente. En el momento de redacción de este capítulo, la programación de los eventos de Girls4STEM está siendo replanificada y las actividades volverán a celebrarse a partir del mes de septiembre en modalidades virtuales, semipresenciales o presenciales, con un aforo limitado atendiendo a las medidas de seguridad establecidas por la Universitat de València y la Conselleria de Sanitat.

Una de las actividades programadas que ampliaba el programa piloto de la ETSE-UV y que tuvo que ser pospuesta es el campus de verano "Campus UV Ingenia Girls4STEM". Este campus estaba previsto este año 2020 para la tercera semana del mes de julio y cuenta con la financiación del Banco Santander y de la Fundación General CSIC a través de la III edición de Cuenta la Ciencia, pues se realiza en colaboración con el Instituto de Física Corpuscular (IFIC). El campus se plantea como objetivos fomentar la cultura científica entre la ciudadanía, y estimular y difundir el estudio de las STEM entre el alumnado de secundaria de la provincia de Valencia, al mismo tiempo que pretende despertar el interés por las vocaciones científicas y tecnológicas entre nuestros jóvenes

\footnotetext{
${ }^{22} \mathrm{http}: / /$ www.facebook.com/Girls4STEM

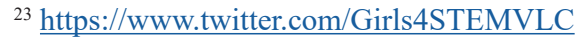

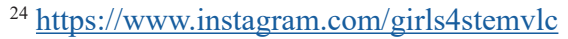

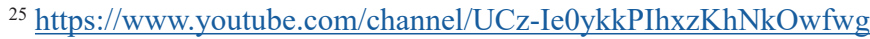

${ }^{26} \mathrm{https}: / /$ youtu.be/DFtC3 q29tM
} 
en general y especialmente entre las jóvenes adolescentes. Para contribuir al enriquecimiento curricular y al desarrollo de capacidades entre las y los jóvenes, promocionando una ciencia inclusiva y sostenible, se ofertaban un total de 36 plazas para jóvenes - 24 chicas y 12 chicos - que cursaran $4^{\circ}$ curso de enseñanza secundaria en centros públicos, concertados o privados. Durante una semana, las y los estudiantes participantes tienen la oportunidad de diseñar, experimentar y desarrollar proyectos científicos a través de la realización de actividades y talleres integrados en las diferentes áreas STEM al mismo tiempo que, gracias a la organización de visitas, podrían conocer las diversas áreas e instalaciones del Campus Burjassot-Paterna de la UV, en el cual se concentran la práctica totalidad de las titulaciones del ámbito STEM de la UV y los diferentes centros tecnológicos y de investigación del parque científico de la Universitat de València. El programa científico se complementa con una serie de actividades lúdicas en las que los y las estudiantes podrán estrechar las relaciones con el resto de participantes. Entre las actividades previstas se encuentran talleres y actividades dirigidas a resolver problemas relacionados con los ODS, además de charlas impartidas por las expertas STEM orientadas a las chicas y chicos que participan en el campus de verano.

Otras iniciativas serían la extensión de los Premios +Dones, que se venían realizando en la ETSE-UV desde el año 2018, a todo el ámbito universitario, recogiendo y analizando la brecha de género en STEM no solo desde el propio ámbito STEM sino desde la percepción del alumnado de cualquier otro ámbito de estudio. El concurso +Dones empezó en 2018 motivado por el bajo número de mujeres que forma parte del personal de la ETSE-UV, tanto de estudiantes como de profesoras. La iniciativa, que se encuentra dentro de las actividades que forman parte del programa de la ETSE-UV, cuenta con el apoyo y colaboración de la Asociación de Representantes del alumnado de la ETSE y de la Women in Engineering (WIE) Student Branch Affinity Group, asociación de alumnas de la escuela que pertenece a la IEEE. Dada la gran acogida de las ediciones anteriores y el elevado número de visitas que recibieron los vídeos presentados por el alumnado, el objetivo este año es extender la iniciativa a toda la Universitat de València, haciendo partícipes de esta situación a todo el conjunto de las personas que forman parte de esta.

La iniciativa ampliada a toda la Universitat de València pretende mantener el formato del concurso de vídeos con un acto de entrega de premios, al igual que en ediciones anteriores, con el objeto de dar visibilidad a las mujeres al ámbito STEM, ofrecer modelos a nuestras estudiantes, reducir las tasas de abandono femenino de los estudios y motivar la creación de redes de apoyo. El concurso consistirá en que cualquier persona miembro de UV podrá presentar un vídeo de corta duración (3 minutos como máximo). El equipo que presenta el vídeo puede estar formado tanto por hombres como por mujeres, pero la protagonista del vídeo ha de ser una mujer. Se plantean dos modalidades para los premios, una para estudiantado de las ramas STEM y otra para el resto, con el objetivo de poder comparar la percepción de la situación de la mujer en función de su contexto académico. En ambos casos, con el vídeo se deberá contestar a la pregunta: "qué cambios tiene que hacer la sociedad y la educación para acabar con la brecha de género en STEM y cómo 
se puede conseguir equilibrar la presencia de hombres y mujeres, tanto en carreras feminizadas como en las masculinizadas".

Asimismo, Girls4STEM colabora en el Programa GEN10S ${ }^{27}$ que pretende concienciar sobre la brecha digital y la necesidad de acercar la tecnología a todos los niños y niñas, apostando por una educación en valores trabajando por reducir la brecha digital y de género para conseguir una igualdad de condiciones. Se trata de una iniciativa de Ayuda en Acción y Google.org.

Entre otras colaboraciones habituales se encuentra la Expociencia ${ }^{28}$ o la reciente creación de mesas redondas y sesiones especiales que incluyan la perspectiva de género en congresos como las JENUI ${ }^{29}$ (Jornadas sobre la Enseñanza Universitaria de la Informática) organizadas por la Asociación de Enseñantes Universitarios de la Informática (AENUI).

Uno de los resultados más importantes del proyecto es que, debido a la difusión de Girls4STEM y la preocupación ante la brecha de género, se ha incluido el proyecto dentro de las iniciativas prioritarias de la recientemente creada Càtedra de Bretxa Digital de Gènere. La inclusión de Girls4STEM dentro de las actuaciones de la Càtedra de Bretxa Digital de Gènere persigue precisamente garantizar la expansión del proyecto a toda la Comunidad Valenciana.

En la actualidad, se cuenta con propuestas de abrir nodos en otras provincias, pero la organización del proyecto apuesta por consolidar primero la propuesta en la Comunidad Valenciana, teniendo en cuenta, además, el reto que supone adaptarse a las nuevas directrices debido a la COVID-19. Por ello, se toma la edición de 2020-2021 como fase de consolidación del proyecto y búsqueda de otros nodos con motivo de la celebración de las XXV JENUI que se celebrarán en Valencia y organiza la ETSE-UV en julio de 2021.

En cualquier caso, el objetivo final es poder exportar el proyecto a otras comunidades autónomas españolas y también fuera de España. Para este aspecto será de gran ayuda la colaboración de la empresa patrocinadora Capgemini, ya que se trata de una empresa multinacional que cuenta con una sección específica de apoyo a la igualdad de género, siendo habitual expandir las iniciativas que apoyan localmente a otras regiones.

\subsection{Referencias bibliográficas}

Benavent, X., de Ves, E., Forte, A., Botella-Mascarell, C., López-Iñesta, E., Rueda, S., Roger, S., Perez, J., Portalés, C., Dura, E., Garcia-Costa, D. y Marzal, P. (2020). Girls4STEM: Gender Diversity in STEM for a Sustainable Future. Sustainability, 12, 6051. Recuperado de https://doi.org/10.3390/su12156051

Bian, L., Leslie, S. J. y Cimpian, A. (2017). Gender stereotypes about intellectual ability emerge early and influence children's interests. Science, 355 (6323), 389-391.

\footnotetext{
${ }^{27}$ https://www.genios.org/

${ }^{28} \mathrm{https://www.pcuv.es/es/expociencia-2020}$

${ }^{29}$ https://jenui2020.uv.es/
} 
Botella, C., Rueda, S., López-Iñesta, E. y Marzal, P. (2019). Gender diversity in STEM disciplines: A multiple factor problem. Entropy, 21 (1), 30. Recuperado de https:// www.mdpi.com/1099-4300/21/1/30.

Cech, E. A. y Blair-Loy, M. (2019). The changing career trajectories of new parents in STEM. PNAS, 116 (10), 4182-4187.

Diekman, A. B., Clark, E. K. y Belanger, A. L. (2019). Finding Common Ground: Synthesizing Divergent Theoretical Views to Promote Women's STEM Pursuits. Social Issues and Policy Review, 13 (1), 182-210.

Duflo, E. (2012). Women empowerment and economic development. Journal of Economic literature, 50 (4), 1051-79.

Fernández, R. y Solano, N. (2017). Attitude towards School Science in Primary Education in Spain. REDIE. Revista Electrónica de Investigación Educativa, 19 (4), 112-123.

Fundación Bancaria "la Caixa", FECYT y Everis. (2015). ¿Cómo podemos estimular una mente cientifica?. Recuperado de https://www.fecyt.es/es/publicacion/comopodemos-estimular-una-mente-cientifica.

Heilman, M. E., Block, C. J. y Lucas, J. A. (1992). Presumed incompetent? Stigmatization and affirmative action efforts. Journal of Applied Psychology, 77(4), 536.

Hunt, V., Prince, S., Dixon-Fyle, S. y Dolan, K. (2020). Diversity Wins: How inclusion matters. McKinsey. Recuperado de https://mck.co/3lqk9NF

iClaves y European Commission. Women in the digital age. Recuperado de https://bit. ly/3iDGbuL

Kitchen, J. A., Sonnert, G. y Sadler, P. M. (2018). The impact of college-and universityrun high school summer programs on students' end of high school STEM career aspirations. Science Education, 102 (3), 529-547.

López-Iñesta, E., Botella, C., Rueda, S., Forte, A. y Marzal, P. (2020). Towards breaking the gender gap in Science, Technology, Engineering and Mathematics. IEEE Revista Iberoamericana de Tecnologías del Aprendizaje, 15 (3), 233-241.

Mateos, S. y Gómez, C. (2019). Libro Blanco de las mujeres en el ámbito tecnológico. Madrid, España: Secretaria de Estado para el Avance Digital, Ministerio de Economia y Empresa. Recuperado de https://bit.ly/2GxEzFU

Merelo, J. J. y Merelo, C. (2017) Evolución de la matrícula femenina en el grado de Informática en universidades públicas españolas. Recuperado de https://bit. ly/3d8yL1f

Rittmayer, A. D. y Beier, M. E. (2008). Overview: Self-efficacy in STEM. SWE-AWE CASEE Overviews, 1, 12.

Rocard, M., Csermely, P., Jorde, D., Lenzen, D., Walwerg-Heriksson, H. y Hemmo, V. (2007). Science Education Now: A New Pedagogy for the Future of Europe. Report for the European Commission. Recuperado de https://bit.ly/2Gy9ySb 
Rueda, S., Botella, C., López-Iñesta, E. y Marzal, P. (2019). Estrategias para aumentar la diversidad de género en la Educación Superior CTIM. En Actas de las XXIV Jornadas sobre Enseñanza Universitaria de la Informática (Vol. 4, pp. 111-118). Recuperado de https://bit.ly/2GK3bep

Sánchez de Madariaga, I., De la Rica, S. y Dolado, J.J. (2011). Libro Blanco sobre la situación de las Mujeres en la Ciencia Española. Madrid, España: Ministerio de Ciencia e Innovación. Recuperado de https://bit.ly/2GHpYHB

Smith, K. N. y Gayles, J. G. (2018). "Girl Power": Gendered academic and workplace experiences of college women in engineering. Social Sciences, 7(1), 11.

Turban, S., Wu, D. y Zhang, L. (2019). When gender diversity makes firms more productive. Harvard Business Review. Recuperado de https://bit.ly/3iBsM6n

UNESCO. (2017). Cracking the code: girls' and women's education in Science, Technology, Engineering and Mathematics (STEM). Recuperado de https://unesdoc. unesco.org/ark:/48223/pf0000253479

Weisgram, E. S. y Bigler, R. S. (2006). Girls and science careers: The role of altruistic values and attitudes about scientific tasks. Journal of Applied Developmental Psychology, 27 (4), 326-348.

World Economic Forum. (2018). The future of jobs report 2018. Geneva: World Economic Forum. Recuperado de https://www.weforum.org/reports/the-future-of-jobsreport-2018. 



\title{
Capítulo 8 Enfermería y género
}

\author{
Francisca Esteve Claramunt \\ Concepción Martínez Martínez \\ Departamento de Enfermería \\ Universidad Europea de Valencia
}

\subsection{El cuidado como centro de la Enfermería}

El cuidado se puede definir como "un acto de mantener la vida asegurando la satisfacción de un conjunto de necesidades indispensables, pero que son diversas en su manifestación. Las diferentes posibilidades de responder a estas necesidades vitales crean e instauran hábitos de vida propios de cada grupo o persona" (Collière, 1993).

Según Lydia Hall, "la enfermería es una disciplina profesional que surge como resultado de la evolución dentro de la sociedad de una actividad humana fundamental, la actividad de cuidar" (citado en Marriner-Tomey, 1994) y cuya finalidad es contribuir a mantener la salud existente o ayudar a mejorarla, recuperar la salud perdida, adaptarse al proceso de enfermedad y ayudar a morir en las mejores condiciones posibles. Para que los cuidados proporcionados en cada una de estas situaciones sean satisfactorios, debemos considerar a la persona de forma integral, teniendo en cuenta tanto la esfera física, como la psíquica y social. Esta forma de entender los cuidados hace que la enfermera o enfermero sea una figura necesaria a lo largo de todo el ciclo vital de la persona.

Las enfermeras (y enfermeros), desde el inicio de la profesión, han elaborado un cuerpo teórico propio formado por modelos y teorías de enfermería que proporcionan distintas formas de entender el cuidado, la enfermería, la salud y la persona en función de los paradigmas presentes en cada una de las épocas históricas por las que ha transitado la enfermería. Estos modelos se pueden agrupar en 6 escuelas: Escuela de las necesidades, Escuela de la interacción, Escuela de los efectos deseables, Escuela de la promoción de la salud, Escuela del ser humano unitario y Escuela del Caring (Keruak, 1996). Para poner en práctica los cuidados de forma profesional, es necesario adoptar un modelo teórico como referente. La identificación de los cuidados necesarios para cada caso en particular se hace a través de la aplicación de distintas metodologías, como el proceso de atención de enfermería (PAE) y la taxonomía diagnóstica.

El proceso de atención de enfermería (PAE) es "un método sistemático y organizado de administrar cuidados individualizados que se centra en la identificación y tratamiento de las respuestas únicas de la persona o grupos a las alteraciones de salud reales o po- 
tenciales y se desarrolla a través de cinco etapas: valoración, diagnóstico, planificación, ejecución y evaluación" (Alfaro, 1996).

Mediante el uso de la taxonomía diagnóstica desarrollada por la North American Nursing Diagnosis Association (NANDA), la enfermera o enfermero determina la respuesta de una persona, familia o grupo ante un problema de salud concreto, valorando las alte-raciones fisiopatológicas, actitudes o emociones, modos de relacionarse con su entorno, etc., que se producen ante determinadas situaciones vitales. En otras palabras, el proceso diagnóstico es una forma de pensamiento crítico que permite llegar a una conclusión acerca del estado de salud y de la respuesta de una persona a su situación vital (Alfaro, 1996).

El uso de estas herramientas metodológicas permite a la enfermera o enfermero valorar a la persona de manera holística, asegurar la máxima calidad de los cuidados prestados y facilitar la coordinación entre aquellos profesionales implicados en el proceso de cuidar. Asimismo, contribuye a la autonomía de la práctica profesional, ya que es la enfermera o enfermero la persona que identifica, diagnostica y soluciona los problemas de salud siendo, por tanto, la única persona responsable del resultado final.

\subsection{Mujer, reformismo y enfermería}

El contexto social de finales del S.XVIII y XIX está marcado por la industrialización. La demanda de mano de obra para cubrir las necesidades de la industria provocó un flujo de población del campo a la ciudad. Las mujeres y niños se incorporaron al trabajo como mano de obra barata y en unas condiciones laborales insalubres. Los bajos salarios obligaron a las familias a vivir en condiciones de hacinamiento. Como consecuencia, los índices de mortalidad infantil llegaron a ser superiores al $50 \%$ en algunas zonas de Gran Bretaña. En cuanto al sistema de atención a los enfermos, la situación no era muy distinta, pues los hospitales y las casas de beneficencia seguían padeciendo las consecuencias a las que condujo la reforma anglicana a los países protestantes. Existía una falta de enfermeras cualificadas que se hicieran cargo de los enfermos y el estado, sin capacidad para hacer frente a la situación, comenzó a contratar mujeres sin ninguna formación y escasa moral, dispuestas a realizar un trabajo que nadie quería por un salario ínfimo.

Como contrapartida a esta situación, surge en Inglaterra el reformismo como una ideología política que intenta dar respuesta a los problemas concretos que afectan a parte de la sociedad, mediante la búsqueda de consenso y de forma sosegada, sin necesidad de efectuar cambios drásticos en las instituciones estatales y las estructuras sociales vigentes en ese momento.

Entre los grandes reformistas ingleses destaca la figura de John Howard (1726-1789). Howard se centró en el estudio del funcionamiento de los hospitales y centros penitenciarios. Consiguió que se realizaran reformas para dispensar un trato más humanitario a los presos, por lo que puede ser considerado uno de los precursores de la reforma del sistema penitenciario. Tras recorrer cientos de centros penitenciarios, pudo observar el 
estado deplorable en que se encontraban presos y enfermos, destacando únicamente a dos organizaciones enfermeras como ejemplo del buen trabajo realizado: las Hermanas de la Caridad y las Beguinas (Siles González, 2011).

Las reformas sanitarias no fueron realizadas únicamente por hombres. Grandes mujeres lucharon para conseguir mejorar las condiciones de los más desfavorecidos. Sin embargo, el papel que tuvieron en la reforma del sistema no ha sido debidamente reconocido. Los cuidados a enfermos y pobres habían estado tradicionalmente en manos de las mujeres, por lo que eran conocedoras de la situación de abandono que se encontraban las instituciones y la necesidad de reorganizar el sistema sanitario para ofrecer mejores servicios. Las ideas feministas se iban abriendo camino tímidamente en Inglaterra, principalmente entre las clases altas, lo que contribuyó a que mujeres como Elisabeth Fry y Florence Nightingale en Gran Bretaña, y Concepción Arenal en España, se negaran a seguir el camino que tenían establecido por el hecho de haber nacido mujeres y continuaran la labor iniciada por reformadores como John Howard.

\subsubsection{Elisabeth Fry}

Elisabeth Fry (1780-1845) rompió con los estereotipos que existían en la época para las mujeres de su clase social y se interesó por la vida de los marginados, en concreto, la vida en la cárcel de las mujeres y sus hijos ya que, en caso de tener hijos, estos debían ingresar también en prisión.

Elisabeth Fry puede considerarse una pionera en la práctica del tratamiento moral en el ámbito carcelario (Giménez Segura, 2008). Comparte con Pinel que la función que deben cumplir las instituciones es reeducativa y que el trabajo remunerado y un entorno ambiental adecuado son fundamentales para su rehabilitación y reinserción en la sociedad (Giménez Segura, 2008). En 1817 fundó la asociación para el desarrollo y mejora de las condiciones de las mujeres recluidas en New Gate, a través de la cual conseguían fondos para libros, ropa y otros enseres, instruían a las mujeres en higiene básica y tareas del hogar, además de acompañarlas y reconfortarlas anímicamente. En 1840 fundó el Instituto de Hermanas enfermeras, con una preparación eminentemente práctica, cuya función inicial era visitar a las presas, aunque más tarde se especializarían en visitas domiciliarias. En 1818 presenta el informe An enquiry into prison discipline ante la Cámara de los Comunes y la de los Lores, siendo la primera mujer que intervino en ambas cámaras. Los cambios legislativos conseguidos permitieron la reforma del sistema penitenciario que se mantiene hasta la actualidad.

\subsubsection{Florence Nightingale (1820-1910)}

Florence Nightingale es reconocida por sus aportaciones a la mejora de las condiciones sanitarias de los hospitales y fundamentalmente por ser la artífice de la reforma que acabó con la etapa más negra en la historia de la enfermería, dignificando y revalorizando la profesión. No obstante, también es necesario reivindicar el papel que ejerció como mujer investigadora, escritora y estadista. 
Florence Nightingale nació en una familia con una posición socioeconómica elevada. A pesar de las ideas vigentes en la época, su padre era partidario de la educación de la mujer y se ocupó personalmente de que Florence se formara en disciplinas tan diversas como: Historia, Ciencias Políticas, Filosofía, Idiomas y Religión, junto a otras menos habituales, como Matemáticas y Estadística.

La formación humanista y sus sólidos valores religiosos le forjaron una fuerte personalidad con firmes convicciones y principios que, en muchas ocasiones, se mostraron contrarios a la ideología vigente. Cuenta que a los 17 años tuvo una llamada de Dios para dedicarse a la enfermería. Sin embargo, tuvo que enfrentarse a la oposición familiar, que concebía la enfermería como una profesión denigrante para una mujer de su posición social.

Florence siguió formándose y viajando para conocer distintos modos de gestión hospitalaria, llegando a trabajar de forma altruista como supervisora en un hospital. Durante la Guerra de Crimea, se originó una epidemia de cólera que estaba acabando con la vida de miles de soldados. Florence fue nombrada inspectora de la institución de enfermería en los hospitales generales ingleses en Turquía y al cabo de unos meses de trabajo la mortalidad en los hospitales pasó del $40 \%$ al $2 \%$. En 1859 comenzó a trabajar por las mejoras de las condiciones del ejército inglés en la India, donde volvió a obtener resultados similares, concluyendo que el exceso de mortalidad era debido a las malas condiciones ambientales de los hospitales y no consecuencia de las heridas recibidas. En su libro Notas sobre enfermería: qué es y qué no es dejó reflejado: "Una mala sanidad, una mala arquitectura y una mala administración a menudo hacen imposible cuidar" (Nightingale, trad. 1990).

Para convencer a las autoridades responsables de la necesidad de una reforma en los hospitales, recurrió al uso de la estadística y la representación gráfica. De hecho, se la considera pionera en el uso de la estadística para medir fenómenos sociales (Young, Verónica, Chambi y Finn, 2011). Una de sus mayores aportaciones al campo de la estadística fue la creación del gráfico de la rosa (diagrama de área polar), en el que se pueden observar de forma gráfica tres variables: el tiempo, el número de muertes y la causa de la misma. Florence tenía una gran facilidad para codificar y ordenar sus observaciones de forma sistemática, llegando a proponer un sistema hospitalario de registro de enfermedades que puede considerarse visionario. Su aportación al ámbito de la estadística fue reconocida con su ingreso como miembro de la Royal Statistical Society y miembro honorífico de la American Statistical Association.

En cuanto a la reforma de la profesión enfermera, Florence organizó la profesión y creó una escuela con formación reglada, iniciándose con ella la profesionalización de la enfermería. Dicha escuela se instaló en el Hospital de Saint Thomas. Durante el periodo de formación, las estudiantes residían en un internado donde, a través del control y la disciplina, se pretendía romper con la imagen negativa que tenía la sociedad sobre la enfermería. Para ella, "la enfermería es un llamado superior, un llamado honorable... El honor radica en el amor por la perfección, la constancia y en el trabajo duro para conseguirla". 
El libro de texto que se utilizaba en la escuela era Notas sobre enfermería: qué es y qué no es. En el campo de la literatura no fue su único trabajo, pues publicó otro libro, Notas sobre hospitales (1859). Del mismo modo, el número de artículos y documentos de su autoría ascienden a 147, destacando dos trabajos sobre epidemiología sanitaria que presentó junto a su maestro Quetelet en el Congreso Internacional de Estadística.

En el ámbito social, el espíritu reformista de Florence Nightingale está marcado por el deseo de mejorar las condiciones sociales a las que se encontraban encadenadas las mujeres en la sociedad victoriana. Al convertir en oficio una actividad que según los estereotipos vigentes en la época era propia del género femenino, posibilitó a las mujeres la emancipación económica.

Durante el siglo XIX fue una de las mujeres más populares de Gran Bretaña: en 1856 fue condecorada por la Reina Victoria de Inglaterra con la Cruz de San Jorge por sus actos durante la guerra y en 1907 el Rey Eduardo VII le concedió la Orden del Mérito, siendo la primera vez que se le concedía a una mujer.

\subsubsection{Concepción Arenal (1820-1893)}

En España, la figura de Concepción Arenal se ha considerado relevante en muchas disciplinas: Derecho, Asistencia Social, Sistema Penal y Beneficencia; pero apenas se ha tenido en cuenta su aportación a la reforma sanitaria y de la enfermería española.

Nace en el seno de una familia acomodada y adquiere su formación intelectual inicial de forma autodidacta. En Madrid, acude como oyente a clases en la facultad de derecho vestida de hombre, ya que estaba prohibido el acceso de la mujer a la formación superior. De hecho, no obtuvo el título universitario por no tener derecho a examinarse. Sus contactos con un gran número de intelectuales, políticos y empresarios le permitieron ampliar sus conocimientos y su visión reformista, desarrollando una gran carrera como periodista, escritora y pensadora.

En cuanto a la reforma sanitaria en España, tuvo un papel destacado. Su pensamiento estaba influido a nivel nacional por el movimiento krausista (Sanz del Río, Gumersindo Azcárate, Fernando de Castro) y por la Institución Libre de Enseñanza de Giner de los Ríos. A nivel internacional, las reformas sanitarias y penales iniciadas por Elizabeth Fry, Florence Nigthingale, Lynde Dix y John Howard inspiraron el inicio de su obra. Concepción se inicia con la crítica a la situación en que se encuentran las mujeres en las prisiones. No obstante, en 1863 llegó a desempeñar un puesto en la administración del estado como visitadora de prisiones en Galicia. Es importante también destacar que contribuyó a la fundación de la asociación de mujeres "Las Magdalenas", cuyo cometido era visitar a las presas en las cárceles. En 1868, el gobierno provisional la nombra Inspectora de Casas de Corrección de Mujeres. Más tarde, durante el transcurso de la Tercera Guerra Carlista, llegó a dirigir el Hospital de Sangre de Miranda de Ebro, donde atendía a los soldados de ambos bandos. 
Concepción Arenal fue el máximo exponente de la enfermería durante estos años. En su obra La beneficencia, la filantropía y la caridad denunció la necesidad de suplir las carencias existentes en cuanto a los servicios y al personal de enfermería, ya que los cuidados hasta ese momento eran desempeñados por mujeres con limitados conocimientos técnicos y culturales. La educación básica no era obligatoria para las mujeres y la mayor parte de ellas eran analfabetas. Basándose en sus observaciones, elabora una crítica fundamentada en 5 criterios de cuidado que deben cumplir las personas que vayan a dedicarse a la enfermería: cuidado en la asistencia, honestidad, aseo, orden y alimentación.

Desde el movimiento reformista promueve la reforma de los hospitales en general y de la enfermería en particular, trabajando por conseguir una enfermería laica. En 1870 ya señaló que era necesaria la unificación de categorías laborales y la necesidad de una escuela de enfermería que expidiese un solo título a nivel nacional. Concepción Arenal realizó un proyecto de reforma de la enfermería española que, aunque no se pudo llevar a la práctica, constituye un referente para la historia de la profesión (Siles González, 2009).

\subsection{Evolución histórica de los estudios de enfermería en España}

En el año 1857 se publica la Ley de Instrucción Pública, más conocida como la Ley Moyano, mediante la cual se regulan las profesiones sanitarias. La Ley Moyano supone un gran avance frente a la legislación previa al introducir la Educación Primaria obligatoria desde los 6 a los 9 años para las mujeres y la obligatoriedad de creación de escuelas femeninas en pueblos de más de 500 habitantes (Ministerio de Fomento, 1857). Esta reforma legal repercutirá de forma positiva en el proceso de profesionalización de la enfermería al contribuir al acceso de la mujer al sistema educativo. Otra de las consecuencias de su aplicación fue la aparición de los reglamentos para la enseñanza de practicante y matrona. Sin embargo, todavía no se hace ninguna mención a la regulación como profesión sanitaria de la categoría de enfermera, que sigue siendo equiparada laboralmente a la de sirvientes de hospital (Siles González, 2011).

La primera escuela de enfermería en España fue la de Santa Isabel de Hungría, fundada en Madrid en 1895 por el Doctor Federico Rubio Gali con la intención de que las enfermeras tuvieran una formación adecuada que les permitiera aplicar unos cuidados de mayor calidad que los que se venía aplicando hasta la fecha. Pero no será hasta 1915 cuando se regule de forma oficial la profesión de enfermería mediante la Real Orden del 7 de mayo, donde se disponía que el Certificado de Enfermera debía ser el mismo en todas las facultades de enfermería del Reino y se determinaba el programa de conocimientos necesario para obtenerlo. A partir de este momento, queda la profesión dividida en tres títulos: enfermera, practicante y matrona. Esta segregación seguirá hasta 1952 (Decreto de 27 de junio de 1952, por el que se organizan los estudios de la carrera de Enfermera), donde se unifican estas tres profesiones en otra distinta, que pasa a denominarse Auxiliar Sanitario Facultativo (que posteriormente pasó a llamarse Auxiliar Técnico Sanitario, ATS), y las escuelas de enfermería como centros de formación profesional se vinculan a la Universidad (Ministerio de Educación Nacional, 1952). Sin embargo, a pesar de 
la unificación del título, en la formación y áreas de actuación seguirían produciéndose diferencias en función del sexo (Tabla 1).

Tabla 1. Diferenciación en función del sexo en las Áreas de actuación

\begin{tabular}{|l|l|}
\hline \multicolumn{1}{|c|}{ Mujer ATS } & \multicolumn{1}{c|}{ Hombre ATS } \\
\hline Régimen de internado & Régimen abierto \\
\hline La escuela estaba integrada en el hospital & Estudiaba en la Facultad de Medicina \\
\hline Formación mayoritariamente práctica & Formación teórica y técnica \\
\hline $\begin{array}{l}\text { Estricto control de rotación por las unidades } \\
\text { hospitalarias }\end{array}$ & $\begin{array}{l}\text { Podían solicitar permiso para determinadas } \\
\text { unidades hospitalarias }\end{array}$ \\
\hline Asignatura: Enseñanza del hogar & Asignatura: Autopsia médico-legal \\
\hline $\begin{array}{l}\text { Desarrollo profesional: Unidades de } \\
\text { Hospitalización }\end{array}$ & $\begin{array}{l}\text { Desarrollo profesional: Servicios técnicas } \\
\text { diagnósticas, laboratorios clínicos }\end{array}$ \\
\hline
\end{tabular}

Fuente: Elaboración propia

La duración de los estudios era de tres años y, aunque el nivel de formación se elevó, la etapa técnica del cuidado estaba plenamente consolidada en enfermería. Los planes de estudios tenían una clara orientación hacia las ciencias médicas, contribuyendo a la formación de ayudantes médicos. No en vano, la dirección de la escuela recaía sobre un médico que también se encargaba de impartir las asignaturas, mientras que la figura de la enfermera quedaba relegada a jefa de la escuela e instructora. Más tarde, se establecieron las especialidades de ATS y se agruparon en especialidades técnicas, especialidades de cuidado en función del problema médico y los cuidados en distintas etapas de la vida, y las especialidades de atención sanitaria. Las especialidades también eran reflejo de la segregación de sexos, ya que los ATS masculinos no podían cursar la especialidad de matrona.

Respecto a la colegiación de los profesionales de enfermería, en 1945 se establece su obligatoriedad para el ejercicio de la profesión. El Consejo General de Enfermería y los Colegios Provinciales estaban estructurados en tres secciones: practicantes, matronas y enfermeras, y la colegiación se realizaba en función del sexo. Los hombres se colegiaban en la sección de practicantes y las mujeres en la de enfermería o matrona, dejando constancia de que en la práctica se seguía produciendo una segregación por sexos que se mantuvo vigente hasta 1977.

La independencia de las escuelas de ATS de la Facultad de Medicina se produce en 1977. Con la entrada en vigor del Real Decreto 2128/1977, de 23 de julio, se crea el título de Diplomado Universitario de Enfermería (DUE) y las escuelas de ATS pasan a denominarse Escuelas Universitarias de Enfermería, que comenzarán a elaborar e impartir sus propios planes de estudios con un cuerpo teórico común para ambos sexos (Tabla 2). 
Tabla 2. Cambios producidos desde la creación del título de DUE

\begin{tabular}{|l|}
\hline \multicolumn{1}{|c|}{ Cambios producidos desde la creación del título de DUE } \\
\hline La dirección de escuela de enfermería es asumida por enfermeras \\
\hline Creación de departamentos dentro de la escuela \\
\hline Las enfermeras obtienen plazas de profesor titular universitario \\
\hline Aparecen las primeras revistas profesionales \\
\hline Las enfermeras llevan a cabo congresos \\
\hline La dirección de enfermería de los hospitales la asumen las enfermeras \\
\hline
\end{tabular}

Fuente: Elaboración propia

En 2003 se aprueba la Ley de Ordenación de las Profesiones Sanitarias, donde se reconoce la enfermería como una profesión sanitaria, se determinan sus competencias en el marco laboral y se sientan las bases para establecer una relación interprofesional. En cuanto al aspecto educativo, se establece la estructura general de la formación que deben recibir.

Con la publicación del Real Decreto 55/2005, de 21 de enero, por el que se establece la estructura de las enseñanzas universitarias y se regulan los estudios universitarios oficiales de Grado y el 56/2005, de 21 de enero, por el que se regulan los estudios universitarios oficiales de Posgrado, que posibilitan el acceso a los programas de máster y doctorado, junto al Real Decreto 1509/2005, de 16 de diciembre, que introduce modificaciones en ambos, los profesionales de enfermería españoles pasan de la Diplomatura al Grado. Se aprueban en ese momento los contenidos y competencias que se incluyen actualmente en los estudios de Grado en Enfermería, en los que ya se recoge explícitamente como competencia que los estudiantes deberán ser capaces de basar las intervenciones de la Enfermería en la evidencia científica, lo que ha supuesto que ya desde la formación de Grado, los futuros egresados deban tener unas competencias necesarias en utilización de resultados de investigación (Esteve-Claramunt, Osca-Lluch, Haba-Osca y GonzálezSala, 2020). El nuevo marco legislativo permite seguir desarrollando la profesión hacia un futuro ya que, a través de la formación y la investigación, se consiguen dos objetivos primordiales: por un lado, mejorar los conocimientos, técnicas y habilidades que permiten a las enfermeras proporcionar cuidados de calidad basados en la evidencia científica que contribuyen de forma eficaz a prevenir las enfermedades, a promocionar la salud y proporcionar los cuidados necesarios durante la enfermedad para poder restaurar la salud perdida; y, por otro lado, contribuyen a generar conocimiento propio, adaptándose a los nuevos paradigmas vigentes en la actualidad.

\subsection{Enfermería desde la perspectiva de género}

El empuje que le dio Florence Nightingale a la profesión no puede ponerse en duda. Las medidas adoptadas para la elección y formación de las futuras enfermeras fueron decisivas para acabar con la etapa oscura de la enfermería. 
Y recordaremos que la enfermera debe de ser una persona de la que se puede uno fiar, capaz de ser "enfermera de confianza", Ella no... puede ser chismosa, ni ligera charlatana; no debo decir que ella debe de ser estrictamente moderada y honesta, pero, más que esto, debe ser una mujer religiosa y devota; ha de respetar su propia vocación...; debe ser una minuciosa fiel y rápida observadora y ha de ser una mujer de buenos modales y delicados sentimientos (González Gil, 2005).

El éxito del método de F. Nightingale contribuyó a que se abrieran nuevas escuelas siguiendo el modelo propuesto por la fundadora de la enfermería profesional. Amparada en un contexto social en que se mantenían intactos los estereotipos asociados a la mujer, siguió perpetuándose en el tiempo la idea de que la enfermería era una profesión femenina, debido a cualidades innatas que la mujer poseía (Wlosko, 2010). Entre estas cualidades se encontraba la sumisión, por lo que enfermería siguió subordinada a las órdenes de la profesión médica (Nightingale, 1990). En sus anotaciones, Florence refiere que las enfermeras no son "hombres de medicina", haciendo una analogía entre hombremédico y mujer-enfermera y refiriéndose siempre a la enfermería en términos femeninos (González Gil, 2005).

Esta ideología ha formado parte del cuerpo teórico de la enfermería y ha conformado la historia más reciente de la profesión, transmitiéndose a las distintas generaciones a través de la formación teórico-práctica. Es necesario recordar que hasta el año 1977, en que Enfermería pasa a ser considerada diplomatura, la formación era impartida por profesionales de la medicina que aceptaban sin ninguna crítica el concepto de subordinación. Montes Jiménez (2002) recoge en su artículo esta frase del año 1975: "Es reverencia que un inferior debe tener a un superior; ahora bien, el médico es superior del ATS por dignidad y por ciencia y por ambos motivos debe respetarle, en él ha de ver un padre".

\subsubsection{La feminización de la enfermería}

La evolución y desarrollo de la enfermería ha estado influida por la visión de género, lo que ha contribuido a que se haya mantenido la feminización de la profesión (Burguete, Martínez y Martín, 2010). En España, en el curso 2019/2020 estaban matriculados en el Grado de Enfermería 47.806 alumnos y alumnas, de los cuales un $82 \%$ correspondía al género femenino. Como se puede observar en la tabla 3 , el número de mujeres matriculadas ha ido incrementándose en los últimos años, en contraposición al de hombres, que ha visto disminuir su número. Esta tendencia se ha mantenido en todas las comunidades excepto en La Rioja, donde el porcentaje de mujeres matriculadas ha disminuido frente a los hombres. Navarra es la comunidad que mayor porcentaje de mujeres matriculadas tiene, un $86.91 \%$. Por el contrario, es en Murcia donde se han matriculado un mayor número de hombres, 23,84\%. Cabe destacar la situación de Canarias, donde la cantidad de hombres matriculados ha disminuido drásticamente en pocos años. En el curso 2016/2017 el porcentaje de hombres matriculados era de un 45,34 \%, disminuyendo hasta el 22,72\% en el curso 2019/2020. 
Tabla 3. Mujeres matriculadas en enfermería según CCAA

\begin{tabular}{|c|c|c|c|c|c|c|c|c|c|c|}
\hline & \multicolumn{2}{|c|}{$2019-2020 * *$} & \multicolumn{2}{|c|}{ 2018-2019 } & \multicolumn{2}{|c|}{ 2017-2018 } & \multicolumn{2}{|c|}{ 2016-2017 } & \multicolumn{2}{|c|}{ 2015-2016 } \\
\hline $\begin{array}{l}\text { Comunidad } \\
\text { Autónoma }\end{array}$ & Matriculados & $\begin{array}{c}\% \\
\text { Mujeres }\end{array}$ & Matriculados & $\begin{array}{c}\% \\
\text { Mujeres }\end{array}$ & Matriculados & $\begin{array}{c}\% \\
\text { Mujeres }\end{array}$ & Matriculados & $\begin{array}{c}\% \\
\text { Mujeres }\end{array}$ & Matriculados & $\begin{array}{c}\% \\
\text { Mujeres }\end{array}$ \\
\hline Andalucía & 7.872 & $78,91 \%$ & 7.785 & $78,62 \%$ & 7.719 & $78,67 \%$ & 7.719 & $78,29 \%$ & 7.660 & $77,28 \%$ \\
\hline Aragón & 1403 & $80,39 \%$ & 1372 & $79,73 \%$ & 1381 & $80,07 \%$ & 685,5 & $79,02 \%$ & 1387 & $78,27 \%$ \\
\hline $\begin{array}{l}\text { Asturias } \\
\text { (Principado } \\
\text { de) }\end{array}$ & 666 & $84,98 \%$ & 632 & $83,54 \%$ & 642 & $83,64 \%$ & 650 & $84,77 \%$ & 651 & $85,10 \%$ \\
\hline Balears (Illes) & 667 & $83,81 \%$ & 668 & $82,34 \%$ & 673 & $81,87 \%$ & 685 & $80,15 \%$ & 675 & $78,22 \%$ \\
\hline Canarias & 2.084 & $77,28 \%$ & 2.056 & $63,76 \%$ & 1.913 & $55,27 \%$ & 1.924 & $54,66 \%$ & 1.877 & $56,64 \%$ \\
\hline Cantabria & 307 & $84,04 \%$ & 320 & $82,81 \%$ & 318 & $82,08 \%$ & 305 & $79,34 \%$ & 317 & $81,70 \%$ \\
\hline $\begin{array}{l}\text { Castilla la } \\
\text { Mancha }\end{array}$ & 2.153 & $79,52 \%$ & 2.029 & $79,35 \%$ & 1.903 & $79,51 \%$ & 1.812 & $80,24 \%$ & 1.769 & $77,50 \%$ \\
\hline Castilla León & 3.823 & $82,24 \%$ & 3.824 & $82,03 \%$ & 3.757 & $81,67 \%$ & 3.717 & $81,37 \%$ & 3.772 & $81,37 \%$ \\
\hline Cataluña & 8.380 & $83,05 \%$ & 8.228 & $82,87 \%$ & 8.074 & $82,19 \%$ & 8.038 & $82,14 \%$ & 8.006 & $82,09 \%$ \\
\hline $\begin{array}{l}\text { Comunidad } \\
\text { Valenciana }\end{array}$ & 5.241 & $81,60 \%$ & 5.062 & $80,76 \%$ & 4.907 & $79,19 \%$ & 4.884 & $78,10 \%$ & 4.937 & $78,63 \%$ \\
\hline Extremadura & 1.294 & $78,05 \%$ & 1.288 & $78,80 \%$ & 1.274 & $79,75 \%$ & 1.312 & $79,19 \%$ & 1.359 & $78,37 \%$ \\
\hline Galicia & 2.176 & $83,24 \%$ & 2.197 & $83,65 \%$ & 2.201 & $83,39 \%$ & 2.204 & $83,74 \%$ & 2.297 & $83,44 \%$ \\
\hline $\begin{array}{l}\text { Madrid } \\
\text { (Comunidad } \\
\text { de) }\end{array}$ & 5.914 & $84,75 \%$ & 5.780 & $83,96 \%$ & 5.555 & $82,71 \%$ & 5.371 & $81,22 \%$ & 5.481 & $81,42 \%$ \\
\hline $\begin{array}{l}\text { Murcia } \\
\text { (Región de) }\end{array}$ & 3.077 & $76,16 \%$ & 2.919 & $75,50 \%$ & 2.751 & $75,36 \%$ & 2.721 & $74,05 \%$ & 2.676 & $73,39 \%$ \\
\hline $\begin{array}{l}\text { Navarra } \\
\text { (Comunidad } \\
\text { Foral de) }\end{array}$ & 932 & $86,91 \%$ & 943 & $87,14 \%$ & 913 & $86,85 \%$ & 905 & $87,09 \%$ & 876 & $86,82 \%$ \\
\hline País Vasco & 1.511 & $82,86 \%$ & 1.492 & $82,64 \%$ & 1.524 & $83,53 \%$ & 1.521 & $82,45 \%$ & 1.537 & $82,89 \%$ \\
\hline Rioja (La) & 306 & $83,99 \%$ & 299 & $88,63 \%$ & 313 & $86,26 \%$ & 307 & $86,97 \%$ & 316 & $88,29 \%$ \\
\hline TOTAL & 47.806 & $81,87 \%$ & 46.894 & $80,95 \%$ & 45.818 & $80,12 \%$ & 44.761 & $79,58 \%$ & 45.593 & $79,50 \%$ \\
\hline
\end{tabular}

Fuente: Elaboración propia. Datos recuperados de:

Ministerio de Universidades a partir de: https://www.ciencia.gob.es

A pesar de que el número de mujeres matriculadas en el grado de enfermería es 4,5 veces mayor al número de hombres, el número de hombres se equipara al de mujeres entre el Personal Docente e Investigador (PDI), y su número va disminuyendo conforme va aumentando la categoría profesional. Como se puede observar en la tabla 4, entre el perso- 
nal contratado ayudante hay un $75 \%$ de mujeres, un $45 \%$ de mujeres tienen la categoría laboral de catedrático de escuela universitaria y un $19 \%$ de catedrático de universidad.

Tabla 4. Distribución PDI en el área de enfermería

\begin{tabular}{|l|l|l|l|}
\hline \multicolumn{1}{|c|}{ 2018-2019 } & Ambos sexos & Mujeres & \% mujeres \\
\hline FUNCIONARIO & 16 & 3 & 18,75 \\
\hline Catedrático de Universidad & 227 & 145 & 63,88 \\
\hline Profesor Titular de Universidad & 34 & 14 & 41,18 \\
\hline Catedrático de Escuela Universitaria & 127 & 88 & 69,29 \\
\hline Profesor Titular de Escuela Universitaria & \multicolumn{3}{l}{} \\
\hline CONTRATADO & 29 & 22 & 75,86 \\
\hline Ayudante & 113 & 77 & 68,14 \\
\hline Profesor Ayudante Doctor & 136 & 87 & 63,97 \\
\hline Profesor Contratado Doctor & 1.089 & 710 & 65,20 \\
\hline Profesor Asociado & 1.383 & 1.007 & 72,81 \\
\hline Profesor Asociado de C.C. de Salud & $\mathbf{3 . 1 5 4}$ & $\mathbf{2 . 1 5 3}$ & $\mathbf{5 3 , 9 1}$ \\
\hline TOTAL &
\end{tabular}

Fuente: Elaboración propia

En cuanto a las enfermeras y los enfermeros en activo, según los datos oficiales publicados por el Instituto Nacional de Estadística, en 2019 había un total de 307.762 profesionales de enfermería colegiados, de los cuales 259.129 eran mujeres, lo que supone un $84,2 \%$ del total. Los profesionales de enfermería con título de matrona/matrón ascendían a 9.236, siendo 8.637 mujeres, un 93,5\% del total, y únicamente un $6.48 \%$ varones. Cabe destacar la elevada proporción de hombres en las juntas de los colegios profesionales: a pesar del mayor número de mujeres colegiadas, el porcentaje medio de mujeres presidentas de colegios de enfermería es del 36,4\%. En cambio, el porcentaje de mujeres que ocupan una vocalía del colegio de enfermería asciende a más del $60 \%$ (Gobierno de España, 2009).

Tabla 5. Mujeres en activo según el Instituto de la Mujer

\begin{tabular}{|c|c|c|c|c|}
\hline \multicolumn{5}{|c|}{ ENFERMERÍA } \\
\hline \multirow{2}{*}{2019} & \% Mujeres & Ambos sexos & Mujeres & Varones \\
\cline { 2 - 5 } & 84,15 & 316.094 & 266.020 & 50.074 \\
\hline \multicolumn{7}{|c|}{ ENFERMERÍA con título de Matrona/Matrón } \\
\hline \multirow{2}{*}{2019} & \% Mujeres & Ambos sexos & Mujeres & Varones \\
\cline { 2 - 5 } & 93,4 & 9.536 & 8.904 & 632 \\
\hline
\end{tabular}

Fuente: Elaboración propia. Datos recuperados del Instituto Nacional de Estadística, a partir de: https://www.ine.es/jaxi/Datos.htm?path=/t15/p416/serie/10/\&file=s08001.px 
En cuanto a la situación de ocupación de cargos directivos en el campo de la sanidad por parte de mujeres, se observa que la tendencia es paralela a la que sucede en las universidades y en los colegios profesionales. Según la Sociedad Española de Directivos de la Salud, siete de cada diez mujeres trabajan en el ámbito de la sanidad pública o privada, pero solo tres de cada diez ejercen cargos directivos de gestión intermedia en las organizaciones sanitarias (gerencias, direcciones médicas, direcciones de enfermería, de recursos humanos, de gestión económica, etcétera). El número ascendería a cuatro de cada diez si se incluyen en estos cálculos a mujeres que ocupan cargos en las subdirecciones de los hospitales y/o son adjuntas a alguna dirección (Sociedad Española de Directivos de la Salud [SEDISA], 2019).

\title{
8.4.2 Identidad de género y división sexual del trabajo
}

Simone de Beauvoir, con su célebre frase "No se nace mujer, se llega a serlo" (Beauvoir, 2005), propone que hombres y mujeres son resultado de un contexto cultural. A partir de este momento, comienzan a realizarse los estudios de género, identificando las bases sobre las que se asientan las desigualdades entre géneros y su influencia en la proyección laboral de la mujer.

\begin{abstract}
La identidad de género es un constructo social, a través del cual se atribuyen a cada género características distintas y definitorias. Lo femenino se asocia a rasgos expresivo-comunales como son afectividad, emotividad y necesidad de establecer relaciones, mientras que lo masculino se asocia a rasgos instrumentales-agentes, relacionados con la productividad, la eficacia, la autonomía, la independencia y la competitividad (Urra Medina, 2007).
\end{abstract}

Observar la enfermería desde una perspectiva de género es investigar, por un lado, cómo los estereotipos que tradicionalmente se han atribuido a la mujer han afectado al desarrollo histórico de la profesión y, por otro lado, las consecuencias que ha tenido sobre ella el sistema de patriarcado, al primar las características propias del género masculino frente al femenino.

La hegemonía de lo masculino frente a lo femenino se observa fácilmente en una profesión altamente feminizada, como es la enfermería. Cuando un hombre entra a formar parte de la profesión no sufre discriminación, al contrario, se le atribuyen características propias de su rol masculino, siendo visto desde el inicio con un estatus superior a sus compañeras, aun ejerciendo las mismas tareas y teniendo conocimientos y experiencia laboral similar (Bernalte Martí, 2015). A nivel interprofesional, la discriminación hacia la enfermería se evidencia porque el clima organizacional favorece las tareas interdependientes relacionadas con órdenes médicas y dificulta las independientes, por lo que la enfermera no puede aplicar de forma rigurosa los planes de cuidados, produciéndose una escisión entre responsabilidad y autonomía. Este clima es reflejo de la situación de subordinación que ha padecido de forma continuada la enfermería frente a la profesión médica. 
La división sexual del trabajo, es decir, la distribución de tareas y responsabilidades en función del sexo, se observa de forma frecuente en la práctica diaria. Se puede distinguir una discriminación a dos niveles, horizontal y vertical:

\begin{abstract}
La discriminación horizontal se produce cuando la distribución de tareas propias de enfermería es distinta en función del género. Se observa con frecuencia que los hombres son requeridos para puestos técnicos e independientes relacionados con la manipulación de aparataje, técnico de laboratorio, técnicas de diagnóstico, informática, etc. puestos en los que no hay una relación de cuidado directa con la persona. Las mujeres, por el contrario, ocupan plazas relacionadas con el cuidado directo del individuo (Mosqueda-Díaz, ParevicKijin y Valenzuela-Suazo, 2013).

La tarea del cuidado directo ha sido y sigue siendo invisible, poco valorada y deseada por los hombres que entran a formar parte de la enfermería. Asociada al ámbito doméstico y ejercida por mujeres, el sistema patriarcal la consideró como secundaria por el hecho de no reportar beneficios económicos, restándole importancia por estimarse consecuencia del amor a la familia, quedándose por tanto en la esfera de lo emocional, sin embargo la actividad realizada por el hombre al estar asociada a una retribución económica consigue un reconocimiento social mayor (Arroyo Rodríguez, Lancharro Tavero, Romero Serrano y Morillo Martín, 2011).
\end{abstract}

La discriminación vertical se produce cuando los hombres consiguen ascender laboralmente de forma más rápida que las mujeres. Como ya se ha comentado ampliamente en el apartado anterior, en el colectivo de la enfermería y, a pesar de que actualmente más de un $84 \%$ de las enfermeras son mujeres, su presencia en puestos elevados: dirección, gestión, supervisión, etc. es anecdótica, estando ocupados en un mayor porcentaje por hombres (Mosqueda-Díaz et al., 2013).

La explicación para la existencia de esta barrera o techo de cristal que impide a las mujeres alcanzar puestos de liderazgo se ha hecho tradicionalmente sobre la base de que el estereotipo asociado al liderazgo es el masculino, "think manager-think male" (Cuadrado \& Morales, 2007). Sin embargo, esta explicación deja fuera de estudio muchas otras dificultades a las que tienen que hacer frente las mujeres para alcanzar puestos directivos, a nivel social, económico, psicológico, relacionados con la organización, etc. por lo que, para explicar la situación actual de las mujeres en relación al liderazgo, se ha propuesto el concepto de "Laberinto", debido la cantidad de obstáculos con los que se encuentran las mujeres para alcanzar un ascenso profesional en relación con los que se han de enfrentar los hombres (Lupano Perugini y Castro Solano, 2010).

La investigación es el principal método a través del cual se puede contribuir a eliminar los estereotipos hacia la profesión de enfermería. Desde el inicio de la profesión, la ciencia enfermera, asumiendo los paradigmas vigentes en cada momento histórico, ha elaborado teorías y modelos, su propio cuerpo de conocimiento, que ha permitido a los profesionales definir sus funciones y organizar la práctica asistencial en torno a la persona y los cuidados como eje vertebral de la profesión. Sin embargo, hay que tener presente que, aunque necesarios porque delimitan el campo de la investigación y el modo de llevarla a cabo, los paradigmas también suponen una limitación, al ocultar a la mirada del 
investigador o de la investigadora los problemas de un colectivo. En otras palabras, los motivos que han originado una situación no pueden ser analizados y comprendidos por encontrarse fuera de los límites de su conocimiento (Kuhn, 2006).

Durante el siglo XIX y gran parte del XX, han coexistido dos creencias que han limitado el crecimiento y desarrollo de la profesión. Por un lado, el modelo patriarcal, que impuso una visión de subordinación de la enfermería a la profesión médica y, por otro lado, la creencia de que la mujer tenía características innatas que la hacían única para ejercer la profesión. Actualmente, han surgido nuevas corrientes filosóficas que permiten observar la profesión enfermera desde un enfoque distinto a como se ha hecho hasta el momento. La filosofía postestructuralista y la feminista presentan elementos convergentes a partir de los que se ha creado el paradigma postestructuralista feminista que, por un lado, reivindica el valor de la subjetividad, es decir, cómo entiende un sujeto su posición en el mundo (en nuestro caso, la mujer) y, por otro lado, atribuye a las estructuras de poder el interés en el mantenimiento de las jerarquías sociales tal como se conocen, al tiempo que limita el acceso al conocimiento pleno, aquel que queda fuera de sus límites. Sin embargo, la teoría admite la posibilidad de que las asunciones vigentes podrían ser modificadas mediante un cambio en las relaciones de poder (Urra Medina, 2007). Este nuevo paradigma permite recorrer la profesión desde sus inicios, conocer los motivos de sus contradicciones y las limitaciones originadas por una profesión feminizada y definir el camino que queremos ir recorriendo para transformar la profesión ante los nuevos retos del futuro.

\subsection{Referencias bibliográficas}

Alfaro, R. (1996). Aplicación del proceso de enfermería: guía práctica (3a ed.). Madrid: Mosby.

Arroyo Rodríguez, A., Lancharro Tavero, I., Romero Serrano, R., y Morillo Martín, M. S. (2011). La Enfermería como rol de género. Index de Enfermería, 20(4), 248251. https://doi.org/10.4321/S1132-12962011000300008

Beauvoir, S. de. (2005). El segundo sexo. Madrid: Ediciones Cátedra, S.A.

Bernalte Martí, V. (2015). Minoría de hombres en la profesión de enfermería. Reflexiones sobre su historia, imagen y evolución en España. Enfermería Global, 37(35), 328-334.

Burguete Ramos, M. D., Martínez Riera, J. R., y Martín González, G. (2010). Actitudes de género y estereotipos en Enfermería. Cultura de Los Cuidados. Revista de Enfermería y Humanidades, 14(28), 39-48.

Collière, M. F. (1993). Promover la vida : De la práctica de las mujeres cuidadoras a los cuidados de enfermería (1a ed.). Madrid: Interamericana.

Cuadrado, I. y Morales, J. F. (2007). Algunas claves sobre el techo de cristal en las organizaciones. Revista de Psicología Del Trabajo y de Las Organizaciones, 23(2), 183-202. 
Esteve-Claramunt, F., Osca-Lluch, J., Haba-Osca, J. y González-Sala, F. (2020). Visibilidad de las revistas de enfermería en los Journal Citation Reports y Emerging Source Citation Index. Revista ROL de Enfermería, 43(5), 341-351.

Giménez Segura, M. (2008). Elizabeth Fry (1780-1845) y Dorothea Dix (1802-1887): dos pioneras del tratamiento moral. Revista de Historia de La Psicología, 29(3), 85-91.

Gobierno de España. (2009). Informe salud y género 2007-2008 : Mujeres y hombres en las profesiones sanitarias (Informes, estudios e investigación). Madrid.

González Gil, T. (2005). Florence Nightingale. Profesionalización de los cuidados desde una perspectiva de la antropología feminista. Cultura de Los Cuidados Revista de Enfermería y Humanidades, (17), 33-40. https://doi.org/10.14198/ cuid.2005.17.06

Instituto Nacional de Estadística (2020). Enfermeros colegiados por tipo de especialidad, año y sexo. [Fichero de datos]. Recuperado de: https://www.ine.es/jaxi/Datos.htm?path $=/ \mathrm{t} 15 / \mathrm{p} 416 /$ serie $/ 10 / \&$ file $=$ s08001.px

Keruak, S. et al. (1996). El pensamiento enfermero. (S. Kérouac, Ed.) (1a ed.). Barcelona: Masson.

Kuhn, T. S. (2006). La estructura de las revoluciones científicas. Madrid: Fondo de cultura económica de España. S.L.

Lupano Perugini, L. M. y Castro Solano, A. (2010). Análisis de características estereotípicas de género en líderes y seguidores. SUMMA Psicológica UST, 7(2), 55-66.

Ministerio de Educación Nacional. Decreto de 27 de junio de 1952 por el que se organizan los estudios de la carrera de Enfermera. (1952). España: Boletín Oficial del Estado.

Ministerio de Fomento. (1857). Ley de Instrucción Pública de 9 de septiembre de 1857. Gaceta de Madrid, (1710), 1-3.

Montes Jiménez, J. F. (2002). La enfermería, una breve aproximación sociológica: desde, donde y hacia donde. Cultura de Los Cuidados Revista de Enfermería y Humanidades, (11), 30-39. https://doi.org/10.14198/cuid.2002.11.07

Mosqueda-Díaz, A., Parevic-Kijin, T. y Valenzuela-Suazo, S. (2013). División sexual del trabajo y Enfermería. Index de Enfermería, 22(1).

Nightingale, F. (1990). Notas sobre enfermería : qué es y qué no es. Salvat. (Trabajo original publicado en 1859).

Siles González, J. (2009). La influencia de Concepción Arenal en la Enfermería Española: Un estudio desde la perspectiva de la historia cultural y el modelo estructural dialéctico. Rev. de Pesq.: Cuidado é Fundamental, 1(2), 154-169.

Siles González, J. (2011). Historia de la enfermería. Valencia: DAE.

Sociedad Española de Directivos de la Salud [SEDISA] (2019). Solo tres de cada 10 socias de SEDISA ejercen cargos directivos de mesogestión en sus organizacio- 
nes. Recuperado de https://sedisa.net/2019/03/04/solo-tres-de-cada-10-socias-desedisa-ejercen-cargos-directivos-de-mesogestion-en-sus-organizaciones/

Urra Medina, E. (2007). La teoria feminista post-estructuralista y su utilidad en la ciencia de enfermeria. Ciencia y Enfermeria, 13(2), 9-16.

Young, P., Verónica, H. de S., Chambi, M. C. y Finn, B. C. (2011). Florence Nightingale (1820-1910), a 101 años de su fallecimiento. Rev. Med Chile, 139, 807-813. 


\section{Parte III}

\section{Perspectivas sociales, psicológicas $\mathbf{y}$ artístico-teatrales}





\section{Capítulo 9 Las sinergias para la inclusión de la perspectiva de género en la docencia universitaria}

Genoveva Ramos Santana

Amparo Pérez Carbonell

Depto. Métodos de Investigación y Diagnóstico en Educación

Universitat de València

\subsection{Consideraciones}

Desde la década de los años noventa del siglo XX han ido aumentado, de forma considerable, los estudios de género, los espacios para su difusión, los institutos universitarios de género y de estudios de la mujer, así como las investigaciones sobre el género y las mujeres (Ballarín, 201; Howie, Tauchert y Howe, 2002). En consonancia, "la parte académica del feminismo" está posibilitando "liberar a la cultura de los sesgos de género" (Evans, 1998, pág. 9). Este hecho, junto a la normativa educativa referente a la introducción de la perspectiva de género (en adelante $\mathrm{PG}$ ) en la educación superior, ha creado un corpus teórico relevante y de grandes propuestas de transformación de la docencia (Donoso y Velasco, 2013; García, González, García y Mena 2017a; Rodríguez e Iglesias 2019; Ruiz y Blasco, 2020; Torres, 2018; Vázquez y López, 2014; Vizcarra, Nuño, Lasarte, Aristizabal y Álvarez, 2015).

Desde este contexto, y tal como establecen la Ley 14/2011 de Ciencia, Tecnología e Innovación y el III Plan de Igualdad de la Universitat de València (2019-2022), creemos necesario promover la inclusión de la perspectiva de género como categoría transversal en la ciencia, la investigación y la innovación. Como docentes universitarias, estimamos esencial desarrollar procesos individuales de reflexión sobre la incorporación y transversalidad de la PG en nuestras asignaturas, pues su inclusión supone un factor de innovación y cambio que responde a las exigencias actuales de la sociedad (Díaz, 2018). Del mismo modo, creemos imprescindible el fomento del aprendizaje colaborativo, e impulsar proyectos de investigación e innovación (en adelante IeI) entre el profesorado para generar dinámicas colaborativas de transformación de los procesos de enseñanzaaprendizaje en pro de la igualdad de género y el aprendizaje no sexista ni discriminador 
(Bartual, Carbonell, Carreras, Colomé y Turmo, 2018). Como se referencia en Ramos, Pérez, Chiva y Moral (2020) -siguiendo a Díaz-Martínez (2018) -,

\begin{abstract}
la mayoría de los diagnósticos y los planes de igualdad de las universidades se preocupan más por la investigación y no se ocupan tanto de la docencia o lo hacen tangencialmente, quizá por: la falta de formación del profesorado, de materiales y recursos didácticos, de referentes y modelos y de conciencia de género; la escasez de experiencias en educación superior; la dificultad de parte del alumnado para percibir discriminaciones de género; el rechazo de parte del alumnado y del profesorado hacia el movimiento feminista (negacionismo) y la no inclusión de género en la innovación docente. Sin embargo, dicha perspectiva supone un giro y un cambio de enfoque al convertirse en una herramienta de análisis y transformación sobre cualquier aspecto de la realidad socioeducativa (pág. 2).
\end{abstract}

Por consiguiente, es indefectible que la PG se incorpore a la planificación de la docencia, a la programación de objetivos de aprendizaje, de los contenidos, a las metodologías activas de enseñanza-aprendizaje, a los recursos didácticos, a las actividades prácticas y a las referencias bibliográficas para garantizar así la formación de una ciudadanía responsable de la igualdad y una docencia de calidad, inclusiva y equitativa, en un contexto de justicia y cohesión social con un fuerte compromiso con la responsabilidad social.

\title{
9.2. Objetivos
}

Este capítulo tiene como objetivo general presentar el proceso de IeI realizado durante dos cursos académicos (2018-2019 y 2019-2020) por un grupo de docentes que buscan mejorar su docencia incorporando de forma rigurosa y sistemática la PG en sus asignaturas. Concretamente, se presenta el quehacer del grupo en dos proyectos de innovación educativa denominados: "Transformar la docencia universitaria a través de la incorporación de la perspectiva de género" y "La transversalidad del género en las metodologías de la docencia universitaria y su repercusión en las competencias del alumnado", financiados por el Servicio de Formación Permanente e Innovación Educativa -SFPIE- de la Universitat de València.

\subsection{Metodología}

Como grupo de docentes, consideramos necesaria la incorporación y atención de la PG como competencia a desarrollar en nuestras aulas, pues con ello contribuimos a la orientación ética de las actividades profesionales, a una mayor sensibilidad en las relaciones de género y a una mayor perceptibilidad ante las estructuras discriminatorias presentes en la sociedad (Bas, Pérez de Guzmán y Vargas, 2014).

Creemos en una forma de crear ciencia y conocimiento centrada en el modelo humanístico investigador (De la Orden, 2004) donde el conocimiento se adquiere haciendo y la investigación alcanza un carácter sensible, tomando consciencia de las dimensiones humanas (Morales, Bermúdez y García, 2018). Se proyecta un proceso donde investigación e innovación se convierten en ejes dinamizadores de los procesos de transformación que se suceden en las aulas. 
Asimismo, este trabajo se plantea desde un modelo de género sensible (Sinnes, 2006) centrado en el pluralismo metodológico donde se integrarán diversas estrategias provenientes de diferentes perspectivas: cuantitativa-exploratoria-objetiva; cualitativa-participativa-colaborativa-interpretativa y crítica-transformadora.

En estos proyectos han participado 22 docentes con 22 asignaturas de 7 departamentos y de diez titulaciones de grado y postgrado de las ramas de Artes y humanidades, Ciencias sociales y jurídicas y de Ciencias de la salud de la Universitat de València, considerándose, por ello, proyectos de IeI transversales, interdepartamentales e interdisciplinares.

Desde este planteamiento de colaboración y asumiendo la relación positiva que se produce al unir investigación e innovación, se programan distintas fases de actuación. Es decir, el trabajo se ha realizado a través de etapas o fases a partir de las cuales se han conseguido los procesos de innovación y transformación de la docencia universitaria. Entre ellas destacamos las siguientes:

a) Revisión documental de la literatura existente en distintas bases de datos sobre las variables, experiencias y estrategias que se han utilizado para la incorporación de la PG en el currículum y en la docencia. Así como, de instrumentos y técnicas utilizadas en estudios previos para el análisis de la PG en la docencia.

b) Revisión y análisis cualitativo de las Guías para una docencia universitaria con PG de la Xarxa Vives d'Universitats (2018).

c) Evaluación inicial de la incorporación de la PG planteada en las asignaturas implicadas en el proyecto. El profesorado explora a través de la lista de autochequeo de Provencio, Arráez, Ayala, Balteiro, Escabias, Fernández, Crumplel, Martínez, Mateo, Moreno y Sancho (2016), en qué medida promueve a través de sus metodologías, actuaciones y actitudes, la igualdad de género en la docencia que imparte. Cada docente establece su línea base para la contrastación de los cambios y la transformación en los diseños docentes posteriores.

d) Diseño y construcción de un instrumento dirigido al alumnado universitario para recoger su opinión como protagonista del proceso de enseñanza-aprendizaje. Dicho instrumento tiene como objetivo conocer la opinión del alumnado implicado en las distintas asignaturas sobre la incorporación de la perspectiva de la igualdad de género en las asignaturas que cursa. En este proceso, el grupo de docentes se convierte en el Comité de Personas Expertas para la validación lógica del instrumento. Como resultante, se obtiene la "Escala de valoración estudiante sobre la perspectiva de género en la docencia universitaria". Posteriormente, se recoge la opinión del alumnado y se detectan aspectos a mejorar.

e) Debate y aprendizaje colaborativo a través de grupos de discusión. Se realizan dos grupos de discusión entre el profesorado, como aprendizaje de metodología socializada. Se desarrollan procesos de evaluación entre iguales para identificar buenas prácticas a replicar en el equipo. Se recoge información de las metodolo- 
gías docentes empleadas para constatar el nivel de inclusión de la perspectiva de género en la docencia.

f) Incorporación de la PG en las asignaturas. Implementación de cambios por parte del profesorado, actualizando o rediseñando, en la medida de lo posible, las guías y las prácticas docentes. La información de dicha innovación se recoge en un autoinforme cumplimentado por el profesorado. Este instrumento se diseña ex profeso y está constituido por un grupo de preguntas-guías para la reflexión crítica y el análisis.

\subsection{Resultados}

Siendo conscientes de que la transformación de la docencia no la conforma un ciclo cerrado de fases o acciones, sino que supone un continuo, un proceso o un camino que se abre a nuevos itinerarios, a continuación se exponen algunos de los resultados hallados en esta andadura.

a) Tras la búsqueda realizada en varias bases de datos (WoS WEB OF SCIENCE, ERIC, Dialnet e InDICEs CSIC) por el propio profesorado en parejas colaborativas, durante los meses de abril a mayo de 2019, se incorporan al gestor bibliográfico Mendeley 183 documentos que incluyen la perspectiva de género en la docencia. Finalmente, y extraídos los valores únicos, son 99 los documentos considerados pertinentes y útiles para esta investigación. Documentos escritos por 213 personas, entre las que un 73,2 \% son mujeres y un $26,8 \%$ son hombres. De los cuales, el 73,8 \% son artículos de revistas científicas, el 10,7 \% libros de secciones, un 7,5\% tesis, un 5,1\% informes, un 1,9\% libros y el resto, las bases de datos utilizadas, los consideran o genéricos o trabajos inéditos. Los años de mayor publicación en torno a esta temática paulatinamente van aumentando a partir del 2010, produciéndose un mayor incremento de documentación durante el año 2013 y en 2018, un 14 \% y un 16\% respectivamente (revisión realizada de 2010 a 2019).

b) Cuando el profesorado participante en el proyecto revisa las Guías para una docencia universitaria con perspectiva de género de la Xarxa Vives d'Universitats (2018) referentes a su área de conocimiento, el grupo selecciona 55 acciones como Buenas Prácticas para incluir en su docencia.

o Estas acciones, y a modo de síntesis, se centran en referencias de buenas prácticas para incorporar en la evaluación; en sus metodologías de enseñanzaaprendizaje y prácticas educativas; en el diseño de los trabajos planteados al alumnado; para atender a la diversidad del alumnado; para explicar y trabajar los contenidos y conocimientos; para trabajar las actitudes y competencias del alumnado; para visibilizar y sensibilizar al alumnado sobre la igualdad y la violencia de género; para aplicar el uso del lenguaje inclusivo; para la incor- 
poración de las mujeres referentes en la bibliografía de la asignatura y para la inclusión de recursos y materiales que potencien la PG.

c) La exploración de la documentación en las bases de datos permite también seleccionar la propuesta de indicadores diseñada por Provencio et al., (2016) como lista de autochequeo. Esta lista presenta una enumeración de características cuya presencia o ausencia se ha de constatar por parte del profesorado. El grupo de docentes participante en el proyecto se autoaplica la checklist, conformando así la línea base del grupo y determinando el estado de la cuestión. Para el autochequeo cada docente realiza una revisión de la guía docente de la asignatura con la que participa en el estudio.

o A modo de síntesis global, los resultados, tras el análisis descriptivo cuantitativo y cualitativo de este instrumento, muestran que los indicadores referentes al uso de un lenguaje inclusivo, no sexista y de visibilización de la mujer son los más utilizados por el grupo. Asimismo, también se utilizan como referentes en sus guías a las mujeres que son conocidas en sus áreas disciplinares, aunque no reflejan de igual manera a las mujeres que no son tan conocidas por su comunidad científica. Además, la mitad del profesorado usa en la bibliografía aportaciones realizadas por mujeres, aunque sin nombres completos y apellidos como medida positiva de visibilización. Aproximadamente la mitad del profesorado visibiliza a las mujeres y sus aportaciones en la presentación de la materia y en sus contenidos. Incluso hay un acuerdo casi mayoritario al señalar que dicha visibilización se hace en el material concreto que recomiendan al alumnado para desarrollar o profundizar los temas. Sin embargo, se refleja la falta de incorporación de la PG en los procedimientos que utilizan para evaluar el aprendizaje del alumnado. Tampoco incorporan dicha perspectiva cuando difunden o comunican información académica a través de la página web de su materia, en la plataforma Moodle, en los anuncios en el campus virtual o en las redes sociales universitarias que utilizan.

d) Como resultado del proceso de diseño y construcción del instrumento para recoger la opinión del alumnado implicado en las asignaturas, se muestra la "Escala de valoración sobre la perspectiva de género en la docencia universitaria", planteada a partir de una escala ordinal tipo Likert graduada con 6 puntos -desde (1) "Nada de acuerdo / Nunca" a (6) "Totalmente de acuerdo/ Siempre"-. Tras el proceso métrico para la creación de escalas de medida y los análisis estadísticos pertinentes, se constata un alfa de Cronbach $(\alpha)$ de 0.95 y queda compuesta por 32 ítems -ver Tabla 1-. 
Tabla 1. Escala de valoración sobre la perspectiva de género en la docencia universitaria. Alumnado.

\begin{tabular}{|c|c|}
\hline \multicolumn{2}{|c|}{ Objetivos y contenidos } \\
\hline 1 & $\begin{array}{l}\text { En la asignatura se han explicitado objetivos ligados a fomentar el principio de igualdad } \\
\text { y no discriminación. }\end{array}$ \\
\hline 2 & $\begin{array}{l}\text { En los contenidos de la asignatura se han visibilizado las aportaciones de mujeres } \\
\text { relevantes en la disciplina. }\end{array}$ \\
\hline 3 & $\begin{array}{l}\text { En la asignatura se ha ofrecido información sobre la posición desigual de hombres y } \\
\text { mujeres en el campo profesional o disciplinar. }\end{array}$ \\
\hline 4 & En la asignatura se han tratado las desigualdades de género. \\
\hline \multicolumn{2}{|r|}{ Lenguaje: comunicación oral y escrita } \\
\hline 5 & $\begin{array}{l}\text { En la asignatura se han nombrado en femenino cargos y profesiones que desempeñan las } \\
\text { mujeres como evidencia de su participación en la vida social y académica. }\end{array}$ \\
\hline 6 & En la asignatura se ha utilizado un lenguaje inclusivo, no sexista que visibiliza a la mujer. \\
\hline 7 & En el material escrito ofrecido en la asignatura se ha empleado un lenguaje no sexista. \\
\hline 8 & $\begin{array}{l}\text { Cuando el profesorado ha realizado presentaciones orales y/o escritas ha alternado el } \\
\text { orden del nombramiento de mujeres y hombres para evitar consolidar la idea de que un } \\
\text { género es prioritario al otro. }\end{array}$ \\
\hline 9 & $\begin{array}{l}\text { En sus intervenciones el profesorado ha utilizado términos y/o frases estereotipadas de } \\
\text { género. }\end{array}$ \\
\hline 10 & $\begin{array}{l}\text { En la asignatura se ha utilizado un discurso dirigido a sensibilizarnos sobre la importancia } \\
\text { de atender a la perspectiva de género en la disciplina. }\end{array}$ \\
\hline 11 & $\begin{array}{l}\text { Durante las clases se ha escuchado por igual tanto las propuestas realizadas por los } \\
\text { alumnos como las realizadas por las alumnas. }\end{array}$ \\
\hline 12 & $\begin{array}{l}\text { En la asignatura se ha sustituido el masculino genérico que puede resultar discriminante, } \\
\text { por sustantivos que designan a ambos sexos (estudiante) y/o sustantivos colectivos } \\
\text { (población) y/o sustantivos abstractos (la dirección). }\end{array}$ \\
\hline \multicolumn{2}{|c|}{ Metodologías, actividades y recursos } \\
\hline 13 & $\begin{array}{l}\text { En esta asignatura se han utilizado metodologías que trabajan por la igualdad (como por } \\
\text { ejemplo: trabajo colaborativo, dinámicas de grupo heterogéneos, juegos de rol, tertulias } \\
\text { dialógicas...). }\end{array}$ \\
\hline 14 & $\begin{array}{l}\text { En la asignatura se han planteado actividades en las que se valora que el alumnado atienda } \\
\text { a la perspectiva de género. }\end{array}$ \\
\hline 15 & $\begin{array}{l}\text { En la asignatura, se han planteado ejemplos, ejercicios o prácticas que ponen de manifiesto } \\
\text { las desigualdades entre mujeres y hombres. }\end{array}$ \\
\hline 16 & $\begin{array}{l}\text { En la asignatura se han incluido imágenes en las que aparecen mujeres y hombres, con el } \\
\text { fin de destacar la presencia de ambos, por ejemplo, en el desempeño de sus profesiones. }\end{array}$ \\
\hline 17 & $\begin{array}{l}\text { En esta materia se han utilizado recursos de enseñanza-aprendizaje para el desarrollo } \\
\text { de la igualdad de género como, por ejemplo: vídeos, páginas web, artículos, trabajos de } \\
\text { investigación, etc. }\end{array}$ \\
\hline
\end{tabular}




\begin{tabular}{|l|l|}
\hline Participación/relaciones \\
\hline 18 & $\begin{array}{l}\text { En la asignatura se ha respetado el turno de palabra con el fin de no deslegitimar o restar } \\
\text { importancia a la voz de las alumnas. }\end{array}$ \\
\hline 19 & $\begin{array}{l}\text { En la asignatura las alumnas y los alumnos han tenido las mismas oportunidades de } \\
\text { participar. }\end{array}$ \\
\hline 20 & En la asignatura se han delegado responsabilidades tanto en alumnas como en alumnos. \\
\hline 21 & $\begin{array}{l}\text { En la asignatura se ha motivado o animado de forma diferente a los alumnos que a las } \\
\text { alumnas. }\end{array}$ \\
\hline 22 & $\begin{array}{l}\text { Las actividades de participación propuestas en la asignatura se han basado en la } \\
\text { cooperación entre géneros. }\end{array}$ \\
\hline 23 & En la asignatura se ha potenciado el respeto entre los géneros. \\
\hline 24 & En la asignatura se ha ayudado a desarrollar la identidad personal de cada estudiante. \\
\hline 25 & En la asignatura se ha dedicado la misma atención a los alumnos y a las alumnas. \\
\hline 26 & $\begin{array}{l}\text { En la asignatura se han empleado las mismas normas (explícitas o implícitas) para las } \\
\text { alumnas que para los alumnos. }\end{array}$ \\
\hline Evaluación \\
\hline 27 & $\begin{array}{l}\text { El procedimiento de calificación utilizado en la asignatura ha tenido en cuenta el género } \\
\text { del alumnado. }\end{array}$ \\
\hline 28 & $\begin{array}{l}\text { En el sistema de evaluación de la asignatura se han incluido distintos tipos de pruebas con } \\
\text { el fin de que se contemplen las necesidades del alumnado en su diversidad. }\end{array}$ \\
\hline Bibliografía \\
\hline 29 & $\begin{array}{l}\text { En la bibliografía utilizada en la asignatura se han visibilizado las aportaciones de las } \\
\text { mujeres académicas y/o científicas. }\end{array}$ \\
\hline 30 & $\begin{array}{l}\text { En las referencias bibliográficas de la asignatura se han estudiado un número equilibrado } \\
\text { de mujeres y hombres relevantes para la disciplina. }\end{array}$ \\
\hline 31 & $\begin{array}{l}\text { En la asignatura, si se ha presentado un número reducido de autoras, se han explicado las } \\
\text { razones contextuales y/o históricas de este hecho. }\end{array}$ \\
\hline Valoración global \\
\hline 32 & En la asignatura se ha aplicado la perspectiva de género. \\
\hline
\end{tabular}

Fuente: elaboración propia

o En cuanto a la opinión del alumnado y, con el uso de esta escala, se recogen 347 encuestas de alumnas y alumnos con una media de edad de 23 años y donde el $84 \%$ tienen género femenino, un $15 \%$ masculino y cerca del $1 \%$ otro género o prefiere no comentarlo.

Son estudiantes que están totalmente de acuerdo con que durante las clases se ha escuchado por igual tanto las propuestas realizadas por los alumnos como las realizadas por las alumnas $(\overline{\mathrm{X}}=5.5 \mathrm{y} \mathrm{ST}=1.04)$; se ha respetado el turno de palabra con el fin de no deslegitimar o restar importancia a la voz de las alumnas $(\bar{X}=5.5$ y ST=1.03); se han delegado responsabilidades tanto en alumnas 
como en alumnos $(\overline{\mathrm{X}}=5.6$ y $\mathrm{ST}=1.02)$ y se ha dedicado la misma atención a los alumnos y a las alumnas $(\overline{\mathrm{X}}=5.6$ y $\mathrm{ST}=0.95)$.

Asimismo, se muestran muy de acuerdo respecto a que en la asignatura se ha utilizado un lenguaje verbal y escrito inclusivo $(\bar{X}=4.4$ y $\mathrm{ST}=1.63)$; se han utilizado metodologías que trabajan por la igualdad (como por ejemplo: trabajo colaborativo, dinámicas de grupo heterogéneos, juegos de rol, tertulias dialógicas...) $(\overline{\mathrm{X}}=4.4$ y ST=1.36); las actividades de participación propuestas en la asignatura se han basado en la cooperación entre géneros $(\bar{X}=4.4$ y ST$=$ $1.65)$; en las asignaturas se ha potenciado el respeto entre los géneros $(\bar{X}=4.9$ y $\mathrm{ST}=1.49)$ y se ha ayudado a desarrollar la identidad personal de cada estudiante $(\overline{\mathrm{X}}=4.1$ y ST$=1,69)$.

Por otro lado, se muestran poco de acuerdo con que en las asignaturas se hayan explicitado objetivos ligados a fomentar el principio de igualdad y no discriminación $(\bar{X}=3.9$ y ST=1.66); en los contenidos de las asignaturas se han visibilizado las aportaciones de mujeres relevantes en la disciplina $(\bar{X}=3.6$ y ST=1.65); se ha ofrecido información sobre la posición desigual de hombres y mujeres en el campo profesional o disciplinar $(\bar{X}=3.6$ y ST=1.69); se han tratado las desigualdades de género $(\bar{X}=3.6$ y ST=1.7); se ha utilizado un discurso dirigido a sensibilizarles sobre la importancia de atender a la perspectiva de género en la disciplina $(\bar{X}=3.7$ y ST $=1.71)$; se han planteado actividades en las que se valora que el alumnado atienda a la perspectiva de género $(\bar{X}=3.6$ y $\mathrm{ST}=1.70$ ); se han propuesto ejemplos, ejercicios o prácticas que ponen de manifiesto las desigualdades entre mujeres y hombres $(\bar{X}=3.5$ y ST $=1.69)$; se han incluido imágenes en las que aparecen mujeres y hombres, con el fin de destacar la presencia de ambos, por ejemplo, en el desempeño de sus profesiones $(\bar{X}=3.8$ y ST=1.76); se han utilizado recursos de enseñanza-aprendizaje para el desarrollo de la igualdad de género como, por ejemplo: vídeos, páginas web, artículos, trabajos de investigación $(\bar{X}=3.6$ y ST=1.74); en la bibliografía utilizada en la asignatura se han visibilizado las aportaciones de las mujeres académicas y/o científicas ( $\bar{X}=3.68$ y ST=1.67); se han estudiado un número equilibrado de mujeres y hombres relevantes para la disciplina $(\overline{\mathrm{X}}=3.2 \mathrm{y} \mathrm{ST}=$ 1.65) y se ha aplicado la perspectiva de género $(\bar{X}=3.9$ y ST=1.73).

Finalmente, cabe destacar que dicen estar nada de acuerdo únicamente al valorar si el procedimiento de calificación utilizado en la asignatura ha tenido en cuenta el género del alumnado $(\bar{X}=1,9$ y ST=1.70).

e) Elaborados los grupos de discusión como técnica participativa cuya finalidad era conocer las metodologías de enseñanza-aprendizaje empleadas por el grupo de docentes para incorporar la perspectiva de género en su docencia -ver Tabla 2-, se recogen reflexiones muy útiles para el proceso de innovación y transformación de la docencia del equipo. 
o En resumen, se obtienen opiniones, percepciones y expectativas, al tiempo que se manifiestan actitudes, inquietudes, necesidades y también innovaciones. Se considera que la PG ha de estar presente en la docencia universitaria y ha de trabajarse de manera transversal, y ha de planificarse e impregnar la organización curricular. Se considera importante la formación para poder implementar dicha PG en el aula y, de este modo, motivar la participación y empoderar a las mujeres para que sean visibles en los espacios públicos. En cuanto a cómo incorpora la PG en su práctica docente, el profesorado que ha participado ha hablado fundamentalmente del empleo del lenguaje inclusivo, de situar la PG al tratar los contenidos didácticos en el aula, la utilización de seminarios, debates y recursos digitales, entre otros. Surge una idea reiterativa respecto a que las metodologías activas y participativas, así como la evaluación por rúbricas, son las que más potencian la incorporación de la PG en la práctica docente. No obstante, también queda constancia de que se puede trabajar dicha perspectiva desde cualquier tipo de metodología, incluso en el caso de las más tradicionales, como la clase magistral, si se hace un uso del discurso docente que muestre y visibilice el estudio diferenciado o diferencial de la consideración de mujeres y varones en nuestra sociedad.

Tabla 2. Preguntas guía para Grupos discusión. Profesorado

¿Qué entendéis por "atender a la perspectiva de género en la docencia universitaria”?

- ¿Consideráis que debe estar presente en la docencia universitaria?

- ¿Qué finalidad tiene dicha transversalidad?

- ¿Creéis que se consigue trabajar transversalmente la perspectiva de género en la universidad?

¿Qué tipo de metodología/s utilizáis en vuestra práctica docente?

- ¿Consideráis que la metodología que utilizáis en el aula desarrolla la perspectiva de género? ¿Por qué?

- De manera concreta, ¿cómo aplicáis la perspectiva de género en vuestras prácticas educativas, en los contenidos de vuestras asignaturas, en los procedimientos de evaluación y/o en los recursos y materiales que utilizáis?

Para concluir, en caso que se haya quedado una perspectiva negativa o conflictiva respecto a la implementación de la perspectiva de género:

- ¿Cómo definiríais una buena docencia con perspectiva de género?

Fuente: Elaboración propia (2020)

f) Por lo que se refiere a las innovaciones metodológicas implementadas, el profesorado constata su proceso de transformación a través del autoinforme. Esta técnica les permite tomar consciencia de la implementación o el diseño de su asignatura con PG. De forma breve, exponen la innovación puesta en marcha, las actividades, los materiales que utiliza y los recursos. Asimismo, plantean el proceso de evaluación para analizar esta perspectiva: plantean desde la coevaluación 
qué hacen y cómo lo hacen, qué procesos de autoevaluación y de evaluación del alumnado siguen y qué información les ha aportado. A modo de síntesis,

o se han planteado y justificado metodologías muy variadas, dado que el grupo que participa en el proyecto está constituido por docentes cuyos estilos de enseñanza-aprendizaje son diversos, como también lo es su práctica docente. Entre ellas: aprendizaje por proyectos; método de casos; aprendizaje colaborativo; metodologías de aprendizaje visual: vídeos, documentales, infografías; metodologías participativas y reflexivas: debates, discusiones; talleres; seminarios; etc.

o Algunas de las aplicaciones didácticas desarrolladas se han materializado en: la mejora de las guías docentes de las asignaturas; revisión y adaptación de las referencias bibliográficas relevantes; la incorporación de las metodologías más idóneas para trabajar la igualdad de género; la formación básica en conceptos relacionados con la igualdad entre hombres y mujeres; detección de las necesidades y/o dificultades en las disciplinas desde la PG; actividades de discusión y reflexión sobre los binomios esencialistas como lo femenino/masculino, su jerarquía e importancia social, y su representación en los espacios profesionales; actividades de reflexión sobre la aportación de las mujeres en la disciplina; y presentación de textos escritos y de audiovisuales alternativos con perspectiva de género; etc.

o Además, en los autoinformes se han efectuado comentarios y valoraciones diversas relacionadas con: la necesidad de la formación previa por parte del profesorado para trabajar por la igualdad entre todas las personas de la comunidad universitaria; el gran reto con el que se encuentran, pues ahora han de llevar la experiencia realizada en una asignatura a todas las asignaturas para el próximo curso académico; la grata sorpresa de percibir que el alumnado agradece esta mirada y la atención a la incorporación de la PG, si bien les cuesta mucho reflexionar sobre la importancia de realizarlo y el esfuerzo que esto supone tanto para el profesorado como para el alumnado. Se señala también la gran importancia del uso de un lenguaje inclusivo en cualquier canal de comunicación del proceso de enseñanza-aprendizaje. Para terminar, entre los inconvenientes que manifiestan, se encuentra la dificultad de hallar recursos y materiales adecuados para trabajar en las aulas universitarias, lo que conlleva tener que elaborar los recursos ad hoc.

g) Por último, se ha realizado una encuesta al profesorado implicado en estos proyectos sobre el grado de consecución de los objetivos y su nivel de satisfacción y, en suma, el $100 \%$ del profesorado que responde está muy satisfecho con el desarrollo de este tipo de proyectos para conseguir la transversalidad de género en la universidad y un 94,70 \% considera imprescindible seguir trabajando en la línea planteada para atender a la perspectiva de género en su docencia. 


\subsection{Conclusión}

Plantear la perspectiva de género en el ámbito de la docencia no es algo novedoso (Aguayo, Freires y Lamelas, 2016; Díaz-Martínez, 2018; García et. al, 2017b; González, 2011; Menéndez, 2013; Montes, 2019; Luengo y Sumaza, 2009; Saldaña, 2011; Vizcarra et. al, 2015). Sin embargo, creemos que esta perspectiva debe formar parte de todos los procesos de innovación en el contexto universitario.

Que un grupo de docentes de distintas asignaturas, de distintas titulaciones y de forma voluntaria desarrolle un proceso de investigación e innovación con un carácter autorreflexivo conlleva integrar el trabajo intelectual en el análisis de las experiencias que se realizan en las aulas. Esto contribuye a la consecución de la calidad en la docencia universitaria, dando un paso más hacia la igualdad pero más allá del convencionalismo social y académico.

Se ha presentado una línea de IeI que implica: fomentar el compromiso socioeducativo, la responsabilidad y la reflexión crítica-constructiva para identificar las prácticas educativas que promuevan la igualdad de mujeres y hombres en todas las ramas de conocimiento; aprender a reconocer el sexismo, ya sea implícito o explícito, en los discursos y prácticas de la universidad; utilizar metodologías activas y participativas para trabajar por la igualdad de género y de oportunidades; describir las aportaciones de las mujeres en las disciplinas; explicar su ausencia; etc.

En estos proyectos, el profesorado aprende haciendo para transmitir no solo contenidos, sino más bien una respuesta actualizada a un tema muy demandado en el siglo XXI: elevar "a todos los seres humanos a la categoría de personas y ciudadanas sin distinción de sexo" (Simón, 2010).

Las sinergias que se han generado entre el profesorado participante están redundando en una mejora sustancial de la gestión, planificación y desarrollo de sus programas curriculares de las materias unido a una actualización de las metodologías docentes. Asimismo, de forma indirecta, pero no circunstancial, se espera incidir en las competencias genéricas del alumnado como son: compromiso ético con los derechos humanos y la igualdad entre hombres y mujeres; reconocimiento y respeto por la diversidad; capacidad crítica y autocrítica; capacidad para resolver problemas y tomar decisiones, compromiso con la identidad, desarrollo y ética profesional y la capacidad para reconocer y valorar los procesos afectivos; entre otras.

\subsection{Referencias bibliográficas ${ }^{30}$}

Aguayo-Lorenzo, Eva; Freire-Esparís, María Pilar, y Lamelas-Castellanos, Nélida (2016). Incorporación de la perspectiva de género en el TFG: una experiencia en el Grado de Economía de la USC. Revista Complutense de Educación, 28 (1), 1128. https://doi.org/10.5209/rev_RCED.2017.v28.n1.48588

\footnotetext{
${ }^{30}$ Los autores han puesto los nombres completos de los y las autoras como estrategia de visibilización.
} 
Ballarín-Domingo, Pilar. (2015). Los códigos de género en la universidad. Revista Iberoamericana de Educación, 68(1), 19-38. http://hdl.handle.net/10481/49984

Bartual-Figueras, María Teresa; Carbonell-Esteller, Montserrat; Carreras-Marín, Anna; Colomé-Ferrer, Josep y Turmo-Garuz, Joaquín (2018). La perspectiva de gènere en la docència universitària d'Economia i Història. RIDU: Revista d'Innovació Docent Universitària, 10, 92-101.

Bas-Peña, Encarna; Pérez-de-Guzmán, Victoria y Vargas-Vergara, Montserrat (2014), Contribución de la lectura a la formación en género en el Grado de educación Social: Estudio descriptivo y censal. Ocnos, 12, 129-148.

De la Orden, Arturo (2004). Producción, transferencia y uso del conocimiento pedagógico. En Leonor Buendía; Daniel González y Teresa Pozo (coords.). Temas fundamentales en la investigación educativa. Aula Abierta. La Muralla.

Díaz-Martínez, Capitolina (2018). La igualdad de género en la docencia universitaria como elemento de innovación educativa. Conferencia presentada a la VI Jornadas de Innovación Educativa, los días 8 y 9 de febrero de 2018 en la Universidad de Málaga. Vicerrectorado de Personal Docente e Investigador.

Donoso-Vázquez, Trinidad y Velasco-Martínez, Anna (2013). ¿Por qué una propuesta de formación en perspectiva de género en el ámbito universitario? Profesorado: Revista de currículo y formación del profesorado, 17(1), pp. 71-88.

Evans, Mary (1998). Introducción al Pensamiento Feminista Contemporáneo. Traducción de Rosalía Pereda. Minerva Ediciones.

García-Holgado, Alicia, González González, Carina, S., García-Peñalvo, Francisco, J., y Mena Marcos, Juan José (2017a). Pretest y postest para evaluar la introducción de la perspectiva de género en la docencia de asignaturas de Ingeniería Informática. Grupo GRIAL. Universidad de Salamanca http://repositorio.grial.eu/handle/ grial/929. doi:10.5281/zenodo.825768

García-Holgado, Alicia; García-Peñalvo, Francisco José; Mena-Marcos, Juan José y González-González, Carina S. (2017b). Inclusión de la perspectiva de género en la asignatura de Ingeniería de Software I. https://gredos.usal.es/jspui/bitstream/10366/135405/1/MID 16 084.pdf

González-Gómez, María Fernanda (2011). Salud laboral y género. Apuntes para la incorporación de la perspectiva de género en el ámbito de la prevención de riesgos laborales. Medicina y Seguridad del Trabajo, 57, 89-114.

Howie, Gillian, Tauchert, Ashley y Howe, G. (2002). Gender, Teaching and Research in Higher Education: Challenges for the 21st Century. Ashgate

III Plan de Igualdad Universitat de València (2019-2022). Aprobado por Consejo de Gobierno el 16 de abril de 2019 cuenta con 64 acciones a desarrollar. Unitat d'Igualtat. Universitat de València. https://www.uv.es/igualtat/webnova2014/IIIPla.pdf 
Izquierdo, María Jesús, Mora, Enrico y Duarte, Laura (2008). Cuidado y provisión: el sesgo de género en las prácticas universitarias y su impacto en la función socializadora de la universidad. Ministerio de Igualdad. Instituto de la Mujer.

Luengo-Rodríguez, Tomasa L., y Rodríguez-Sumaza, Carmen R. (2009). Enfoque de género en la docencia universitaria: apuntes para la elaboración de un protocolo de buenas prácticas. En $\mathrm{M}^{\mathrm{a}}$ Elena Jaime de Pablos (Ed.). Identidades femeninas en un mundo plural (pp. 441-448). Audem.

Menéndez-Menéndez, María Isabel (2013). Metodologías de innovación docente: la perspectiva de género en Comunicación Audiovisual. Methodologies for Teaching Innovation: The Gender Perspective in Audiovisual Communication. Historia y Comunicación social, 18, 699.

Montes-de-Oca-O’Reilly, Alejandra (2019). Dificultades para la transversalización de la perspectiva de género en una institución de educación superior. Revista Latinoamericana de Educación Inclusiva, 13(1), 105-125. https://dx.doi.org/10.4067/ $\underline{\text { S0718-73782019000100105 }}$

Morales-Hidalgo, Paulina de los Ángeles, Bermúdez-García, José Ángel y García-Zacarías, Jean Carlos (2018). El fenómeno del conocimiento como problema en la investigación educativa. Sophia, Colección de Filosofía de la Educación, 25(2).

Provencio-Garrigós, Herminia, Arráez-Llobregat, José Luis, Ayala-Aracil, María de los Ángeles, Balteiro, Isabel, Escabias-Lloret, Pilar, Fernández-Arrillaga, Inmaculada, Grümpel, Claudia, Martínez-Lirola, María, Mateo-Ripoll, Verónica, MorenoSeco, Mónica \& Sancho-Carbonell, Isabel (2016). Implementación de la perspectiva de género en la docencia universitaria de la Facultad de Filosofía y Letras. Innovaciones metodológicas en docencia universitaria: Resultados de investiga-ción (pp. 1703-1718). Instituto de Ciencias de la Educación.

Ramos-Santana, Genoveva, Pérez-Carbonell, Amparo, Chiva-Sanchis, Inmaculada y Moral-Mora, Ana Ma . (2020). El binomio “Investigación + Innovación” para abrazar la perspectiva de Género en la docencia universitaria. Tirant Lo Blanch (en prensa).

Rodríguez-Jaume, María José, y Iglesias, Encina. C. (2019). Guías para una docencia con perspectiva de género. In (Re) construíndo o coñecemento: A Coruña, 14 de xuño de 2019 (pp. 297-302). Universidade de Santiago de Compostela.

Ruiz-Cantero, María Teresa, y Blasco-Blasco, Mar (2020). Perspectiva de género en epidemiología clínica. Aprendiendo con el caso de las espondiloartritis. Gaceta Sanitaria, 34(1), 83-86. https://doi.org/10.1016/j.gaceta.2018.09.004

Saldaña, María Nieves (2011). Los Estudios de Género en los Grados en Derecho: Propuestas para un diseño curricular de la enseñanza del Derecho Constitucional con perspectiva de género en el Espacio Europeo de Educación Superior. Revista de educación y derecho, (3). 
Sinnes, Astrid (2006). Three approaches to gender equity in science education. Nordic Studies in Science Education Nordina, 20(3), 72-83.

Simón-Rodríguez, $\mathrm{M}^{\mathrm{a}}$ Elena (2010). La igualdad también se aprende: cuestión de coeducación. Narcea

Torres-Díaz, María Concepción (2018). Guía docència i Recerca Sensible al Gènere 'Derecho y Criminología. En colección Guies per a docència universitària amb perspectiva de gènere. Xarxas Vives d'universitats.

Vázquez -Verdera, Victoria y López -Francés, Inmaculada (2014). La perspectiva de género y el papel de la Universidad en el siglo XXI. Teoría de la Educación. Educación y Cultura en la Sociedad de la Información 15 (4), 241-261.

Vizcarra-Morales, María Teresa; Nuño-Angós, Teresa; Lasarte-Leonet, Gema; Aristizabal-Llorente, Pilar y Álvarez-Uria, Amaia (2015). La perspectiva de género en los títulos de Grado en la Escuela Universitaria de Magisterio de Vitoria-Gasteiz. REDU: Revista de Docencia Universitaria, 13(1), 14. https://doi.org/10.4995/ redu. 2015.6448

Xarxa Vives d'universitats (2018). Guías para una docencia universitaria con perspectiva de género. Xarxa Vives d'universitats. https://www.vives.org/coleccio/guiesper-a-una-docencia-universitaria-amb-perspectiva-de-genere/ 


\title{
Capítulo 10
}

\section{Fomento de la participación}

de personas mayores en Perspectiva de Género: una

\section{experiencia con agentes activos de cambio social}

\author{
Julia Haba-Osca \\ Depto. Filología Inglesa y Alemana \\ Sandra Simó Teufel \\ Depto. de Psicología Básica \\ Universitat de València
}

\subsection{De dónde venimos: breve historia del feminismo}

"El feminismo es una apelación al buen sentido de la humanidad". Con esta frase proclamaba la escritora Mary Wollstonecraft la razón de ser de un movimiento vindicativo que no había adquirido aún carta de naturaleza pero que encontraba ya, en el siglo XVIII, sus fuentes conceptuales, sus signos de identidad teóricos y sus cabales defensores. Olympe de Gouges, Poullain de la Barre y Nicholas de Condorcet en Francia; o Josefa Amar y Borbón y el Padre Feijoo, en España, por ejemplo, se atrevieron con los primeros textos en defensa de la igualdad política y social de las mujeres, en un momento en que aquella idea era concebida aún como una provocación contra natura.

Pero el sueño que tuvieron aquellos hombres y mujeres proyectando en el futuro sus expectativas de una humanidad más igualitaria, lejos de caer en un rincón marginado de la historia, se convertiría en el cimiento de una corriente teórica, que desde entonces no dejaría de estar presente en las tribunas políticas e intelectuales. Siendo que, derribadas las jerarquías estamentales al calor de los principios de la Revolución Francesa, el objetivo de estas prefeministas ilustradas era derribar también la aristocracia del sexo. En palabras de Amelia Valcárcel (2014): 
Fomento de la participación de personas mayores en Perspectiva de Género: una experiencia con agentes activos de cambio social

Como el sexo en el que uno nace no se elige, no puede ser una condición que te merme libertades. No se puede mantener ni permitir de ningún modo que la inteligencia, el corazón y el mérito estén asignados a un sexo determinado. En eso varones y mujeres somos iguales, y esta idea nace en el contexto de la filosofía de Descartes.

Aquella primera ola de feminismo siguió recogiendo frutos teóricos hasta mediados del siglo XIX cuando surge la denominada segunda ola, la del feminismo sufragista, que se movía ya a ambos lados del Atlántico y que tendría como hito inaugural la Declaración de Seneca Falls, como adalides teóricos a John Stuart Mill, Harriet Taylor y Cady Stanton entre otras, y como nuclear frente de lucha, el derecho al voto femenino. Mientras tanto, quienes sentaron las bases del feminismo español fueron Concepción Arenal y Emilia Pardo Bazán, nutridas por las corrientes de pensamiento que revolucionaron la Europa del industrialismo. En sus textos van ahondando en la desnaturalización de lo femenino, abogando por la visibilización de las mujeres en la esfera pública y buscando la pertinencia intelectual y militante de cada nuevo concepto. Se trata, pues, de un valioso legado que servirá como fundamento a las leyes republicanas aprobadas en defensa de la igualdad de la mujer.

En 1949 se publica la obra que da por inaugurada la tercera ola del feminismo: El segundo sexo, de Simone de Beauvoir. En ella, la autora se embarca en la búsqueda de las condiciones de posibilidad teóricas del feminismo. Dotada de los instrumentos conceptuales existencialistas, radicaliza la idea de igualdad al afirmar que: "la mujer no nace, se hace". Así, el feminismo hace causa común con el pensamiento filosófico en la constatación de que todo poder, incluido el patriarcal, tiene que ver con una genealogía. Por tanto, la ética se alía con el pensamiento feminista ayudando a centrar discusiones erráticas, a rescatar una noción de virtud secuestrada por la religión y a definir una idea transcultural de justicia, capaz de sobreponerse a situaciones de discriminación, dominio y violencia, como las que asolaron España durante el franquismo. Fueron décadas de desierto intelectual que secaron el anhelo de miles de mujeres, condenándolas a vivir bajo parámetros morales decimonónicos.

No obstante, durante los años 70, cuando las mujeres españolas llegan a la universidad representando el $30 \%$ del alumnado, que es lo que se suele llamar el porcentaje de masa crítica, se empieza a organizar rápidamente un movimiento que luego acaba coincidiendo con el gran movimiento de liberación de las mujeres que está ya en todo occidente en los años 70. Como un eco lejano llegaban también del otro lado del Atlántico textos audaces como La mística de la feminidad de Betty Friedan, que denunciaba la sensación de vacío de las mujeres al ser definidas exclusivamente por sus funciones de esposa, madre y ama de casa. Como representante del feminismo liberal entendía que las mujeres habían sido atrapadas por esa "mística de la feminidad" cerco que solo podían romper incorporándose al mundo del trabajo.

En 1975, dos semanas después de la muerte de Franco, se celebraba en la clandestinidad el primer "Día de la Liberación de la Mujer". Estos vientos de cambio propiciaron la salida a las calles de un ideario feminista que había ido gestándose en silencio con 
el impulso de las corrientes libertarias americanas y europeas. Las primeras feministas teóricas cayeron en la cuenta de que narrar reflexivamente una tradición emancipatoria tenía efectos emancipatorios, que había que pasar de la anécdota a la categoría y que conceptualizar, era en realidad, politizar.

La periodización del movimiento feminista constituía la base de la vindicación. Se iniciaba la reconstrucción de las categorías políticas modernas, la identificación de paradigmas y la redefinición de una terminología capaz de explicar la insoportable vivencia de las mujeres durante siglos de opresión. Si las mujeres reclamaban ser incluidas en lo genéricamente humano era porque lo genéricamente humano había sido usurpado históricamente por los varones (Peredo \& Haba-Osca, 2019). Al mismo tiempo, estos avances teóricos avalan en la vida real el éxito profesional de algunas mujeres y el lenguaje que, al definir las cosas, las emociones y los pensamientos, es el más poderoso continente de ideología sexista que ha condicionado durante siglos el modo en que la mujer es categorizada y pensada.

La teoría feminista, por tanto, ha ido haciendo de cada escollo un desafío, buscando nuevas alianzas epistemológicas con las que explicar los nuevos problemas. Como han demostrado los estudios de campo de pioneras como Margaret Mead (2019), la antropología postcolonial y, en particular, la antropología política, han permitido elaborar teorías cada vez más rigurosas. La explicación del sexismo como una economía política del sexo resultó crucial en la definición del sistema sexo-género, como el conjunto de disposiciones por el que una sociedad transforma la sexualidad biológica en producto de la actividad humana. Acuñado por las feministas académicas anglosajonas, el concepto de género ha sido el mayor hallazgo conceptual de la teoría feminista. Una categoría empírica que ayuda a pensar los modelos normativos que encarnamos desde nuestros sexos biológicos y que define las relaciones de poder entre hombres y mujeres.

Gracias a estos avances teóricos quedaron atrás aquellos prejuicios asentados en el imaginario colectivo como las llamadas "virtudes femeninas". La filosofía moderna ha puesto en su lugar cada concepto extraviado, borrando de una vez por todas ese sesgo fatal que condenaba a las mujeres a todo lo menor, o que concebía como menor, valores como el cuidado, que no han hecho sino contribuir al progreso de lo genéricamente humano. Entonces, el valor del cuidado, que en realidad puso de relieve la psicóloga Carol Gilligan, intentaba elaborar una teoría que sirviera de complemento a la teoría de Kohlberg, que tenía un prejuicio muy masculino, de cómo se forma a la personalidad moral. Y pensó en esa idea del cuidado como el valor que sintetiza las preocupaciones morales de la mujer, que tiene que ver con la cercanía a los demás, con sentirse responsable de los que tiene más cerca, con esa necesidad de cuidar a los demás, a los niños, a los enfermos, a los ancianos, etc.

El feminismo constata en los años 90 la existencia del techo de cristal. Este término, en inglés "Glass ceiling barriers" aparece por primera vez en 1986 en un artículo del Wall Street Journal, describiendo las barreras invisibles con las que topan mujeres altamente cualificadas que, independientemente de sus capacidades, sus logros y méritos, les impi- 
den alcanzar niveles más altos en la jerarquía profesional. Existen seis grandes ámbitos de poder en los que el techo de cristal se manifiesta de forma más contundente: el público-político, el económico-empresarial, el ámbito de la creatividad, el de los medios de comunicación, el medio académico y, muy especialmente, el ámbito religioso. Estos son seis enormes ámbitos de poder donde las mujeres, por cualificadas que estén, casi nunca suben del tramo medio; habitualmente ocupan los tramos bajos, incluso pueden llegar a ocupar parte de los tramos medios, pero pasar a las élites es como si hubiera un enorme techo invisible, que no se ve ni sabe de qué está hecho, pero ahí está innegablemente, porque ellas no logran subir. Y ahí es donde se instala la agenda del feminismo que es la agenda de la paridad.

Por todo lo anteriormente expuesto, se puede afirmar que el feminismo es siempre una vanguardia. Es una teoría en constante renovación, un cambio de paradigma de tal magnitud que ha tenido que ser inyectada en todos los campos de conocimiento, haciendo de la transversalidad estandarte y del proceso de autoconciencia herramienta fundamental.

Siendo una de las últimas tendencias de la teoría feminista, el Ecofeminismo, que no es más que un diálogo entre lo que postula el movimiento feminista y el movimiento ecologista. Este diálogo adquiere una gran importancia en el momento en el que vemos que algunas de las raíces que permiten explicar o comprender la subordinación y el deterioro de la naturaleza y también el sometimiento y dominación de las mujeres en los sistemas patriarcales tienen algunas raíces que pueden ser comunes. Del mismo modo, cuando nos planteamos cómo salir de estos sistemas de dominación y cómo crear de alguna manera culturas y economías que puedan ser armónicas con el planeta que nos sostiene, y con el marco de relaciones imprescindibles que tienen que tener las personas entre sí para poder también sostenerse, nos damos cuenta de que puede haber también elementos y pautas comunes y es desde ahí desde donde vamos a tener que combatir.

Realmente, es un esfuerzo en este momento hacer que se abran caminos al talento femenino y al mérito, de tal manera que en las élites estén igualmente representadas todo lo que valen las capacidades y los saberes que han adquirido. En El siglo de las mujeres, Victoria Camps subraya las tres grandes carencias que siguen mermando la vida de las mujeres aún en países como España. Además del techo de cristal, que relega a las mujeres a una perpetua medianía profesional, la desigualdad en la vida doméstica y nuestra gran lacra, la mal llamada violencia de género, persiste en el menoscabo de la vida de numerosas mujeres, reproduciendo comportamientos intolerables, aún pendientes de superar.

\subsection{Hacia dónde vamos: la importancia de la Igualdad de Género}

La ciudadanía mundial está llamada a alcanzar los Objetivos de Desarrollo Sostenible que promueve Naciones Unidas en su Agenda 2030, aprobada en otoño de 2015. Como potenciales agentes de cambio social que somos, tenemos metas que cumplir para su- 
perar la gravísima situación de desigualdad, pobreza, hambre e injusticia que muchas regiones, países y comunidades humanas padecen en todo el planeta.

Desde la Universitat de València nos hemos propuesto incidir en la expansión de una ciudadanía universitaria comprometida con su tiempo y con estos retos mundiales (Artigas, 2015). En esta institución se ha considerado que la humanización de las disciplinas continúa siendo esencial en la formación integral de las personas y en sus relaciones humanas. Se trata de una política pública fundamental en el ejercicio de su responsabilidad social y, de entre diversas líneas de trabajo, la formación y la sensibilización en temas de educación para el desarrollo sostenible son claves para el fomento de una ciudadanía global.

Para ello, disponemos de diversos instrumentos docentes, siendo uno de los más destacados el programa "Universitat i Societat", más conocido como UNISOCIETAT. Esta iniciativa surge del firme compromiso de los Ayuntamientos de Alzira, Benetússer, Bétera, Cullera, 1'Eliana, Massamagrell, Paterna, Quart de Poblet, Requena y Riba-Roja de Túria por la formación continua o a lo largo de la vida con el apoyo de la Universitat de València. Esta formación va dirigida a estudiantes a partir de los 30 años de edad, procedentes de estos municipios y sus alrededores, con inquietud por aprender y motivación por la cultura. Se implanta a través de un itinerario multidisciplinar de 120 horas por curso académico, acompañado de un ciclo de conferencias de formación complementaria y variado contenido.

Los objetivos generales de UNISOCIETAT son los siguientes:

1. Sensibilizar sobre el valor de la formación a lo largo de la vida, apreciando especialmente la valiosa contribución que las personas de más edad hacen a la sociedad.

2. Promover la solidaridad intergeneracional, la vitalidad y dignidad de todas las personas, y esforzarse más para movilizar el potencial de las personas mayores haciendo posible una formación adecuada.

3. Estimular el debate y el intercambio de información con tal de desarrollar el aprendizaje mutuo.

4. Promover actividades que luchen contra la discriminación como por ejemplo evitar recaer en estereotipos relacionados con la edad, el sexo, la religión, etc.

En el curso académico 2019-2020, con motivo de la demanda para impartir el curso "Perspectiva de Género" en la sede de Quart de Poblet, tuvimos la oportunidad de poner en marcha un taller de formación piloto para vincular una iniciativa transversal que persigue el cumplimiento de las metas marcadas en la Agenda 2030. De este modo, fue posible en 10 sesiones la apertura de un espacio para la reflexión y la acción, tomando como base la educación multidisciplinar para la igualdad de género y proyectándolo hacia una consciencia de los objetivos que deben guiar la erradicación de las desigualdades sociales. 
Aquella experiencia inicial reunió en un mismo espacio alrededor de 50 personas mayores (jubilados/as, profesores y profesoras, amas de casa, personal sanitario y personal de servicios del ayuntamiento local) que lograron apropiarse de referentes feministas e interpretarlos en clave de logros de la sociedad a lo largo del tiempo. La metodología empleada en todas las sesiones fue, por ende, la de identificar elementos de nuestra propia vivencia para comprenderlos y reconocerlos como patrimonio cultural inmaterial, aportando sus experiencias vitales como contribuciones al desarrollo humano sostenible. Las manifestaciones de esta lucha, tanto individual como colectiva, cobran un nuevo valor en la mirada de las personas mayores que forman parte de la comunidad universitaria y que desean exponer su percepción sobre la Perspectiva de Género a nivel local para explicarlo en clave global (Walker, 2006).

Consideramos que el pasado es importante para el desarrollo de la ciudadanía de hoy, para la construcción de las opciones de vida de las personas mayores y para ser agentes activos en su propio desarrollo y el de su entorno, de ahí que las primeras sesiones se dedicasen a la introducción de una breve historia del feminismo. A partir de ahí, los y las participantes han hecho suyo este curso, aportando sus propuestas, identificando elementos simbólicos de gran valor social y cultural, transitando más allá de las clases magistrales generalistas y avanzando hacia espacios de acción diversos, menos evidentes, pero sustancialmente importantes para la ciudadanía del siglo XXI. De ahí que debamos agradecer su presencia a todas las personas que apostaron por esta formación, sin cuyas valiosas aportaciones no hubiera sido posible.

\section{3. "Perspectiva de Género": objetivos y dinámica del curso}

En el curso teórico-práctico y experimental que proponemos, "Perspectiva de Género", queremos contribuir a implementar en nuestra sociedad el principio de igualdad entre hombres y mujeres, especialmente entre las personas mayores, sus discursos y sus actitudes. Para ello, no solo ofrecemos acceso a propuestas teóricas y conceptuales sobre el feminismo, los derechos humanos y el género en desarrollo, entre otros temas actuales, sino que también creamos un contexto de reflexión y escucha sobre temas que afectan a la vida cotidiana de las y los participantes, como la conciliación, la corresponsabilidad y las buenas prácticas en la organización del tiempo.

Consideramos que esta iniciativa puede prolongarse para cubrir ciertas necesidades en la propia comunidad universitaria: tiene que ver con el compromiso y la responsabilidad institucional de promover los derechos humanos y la Agenda 2030 entre estudiantes de la tercera edad; tiene que ver con el fomento universitario de una ciudadanía global (Martinell, 2015) no solo competente, sino capaz (Unceta, 2013) de lograr ese desarrollo; tiene que ver con aplicar otras formas didácticas que incluyan la perspectiva de género en clave de los Objetivos de Desarrollo Sostenible (ODS) para desarrollar asignaturas y materias; tiene que ver con establecer relaciones dialógicas de integración y acogida a cualquier persona o colectivo que se acerque a estas aulas; tiene que ver con proyectar una imagen solidaria, comprometida y crítica de nuestra propia academia y de 
esta ciudad desde la participación horizontal y diáfanamente entendida; y tiene que ver con recuperar en el ideario colectivo universitario la fuerza y los valores de aquello en lo que nos reconocemos como ciudadanía del siglo XXI.

El objetivo principal del curso es crear un contexto de diálogo e interacción respetuosa entre los y las participantes que permita: visualizar la situación actual de la mujer y del hombre en la distribución desigual del poder, cuestionarse los valores sociales de falta de equidad y los estereotipos en torno al género tan profundamente arraigados, y generar soluciones prácticas y adaptadas a la cotidianidad en el funcionamiento individual, familiar y comunitario (ver tabla 1). Las actividades del curso van orientadas a fomentar cambios en el comportamiento y las actitudes de las personas (ver tabla 2).

\section{Tabla 1. Objetivos del curso}

\section{Fundamentación/contextualización del curso}

- Adquirir una capacidad reflexiva interdisciplinar sobre el sistema género y las relaciones entre personas que se generan.

- Identificar los procesos individuales, sociales y culturales que causan y sustentan las diferencias y desigualdades en función del sexo y el género, así como sus consecuencias.

- Reconocer y manejar los conceptos básicos sobre las desigualdades en relación a la conciliación de la vida personal, familiar y laboral, y la importancia en la nueva estrategia de la corresponsabilidad

- Conocer las medidas, los derechos y recursos de los que se dispone para conseguir una mayor calidad de vida al tener que conciliar las tareas del espacio privado y el público.

Fuente: Elaboración propia (2020)

Generar un cambio transformacional en "Perspectiva de Género" no resulta fácil, puesto que la resistencia parece ser una parte intrínseca del cambio para la igualdad de género. El sistema social consiste en procesos interactivos, en los que el género funciona como un punto de referencia para establecer la división del trabajo, determinar las interacciones diarias entre las personas, construir símbolos e imágenes, así como fundamentar las identidades de las personas (Acker, 1990). El género es, así pues, un constructo que vertebra la organización y el funcionamiento del sistema y, por ello, ponerlo en duda supone introducir un desequilibrio en el mismo. La resistencia es una herramienta del sistema que permite a las organizaciones dominantes mantener el equilibrio cuando se enfrentan al cambio y a la duda (Bleijenbergh, 2018; Dent and Galloway, 1999; Lewin, 1946). En este sentido, las organizaciones, así como sus miembros, muestran una tendencia a restaurar y mantener las normas, creencias y valores en torno al género para mantener el equilibrio. El cambio supone un reto emocional y cognitivo, no solo para el/la receptor/a del cambio sino también para los/las agentes del cambio (Bovey y Hede, 2001). El cambio significativo supone que la persona piense de forma distinta, crea de forma distinta y se comporte de forma distinta, y esto es solamente posible a través del diálogo entre las personas (Jones y Van de Ven, 2016). 
Fomento de la participación de personas mayores en Perspectiva de Género: una experiencia con agentes activos de cambio social

En el curso se cuida el crear una dinámica de grupo basada en la confianza y el respeto, que permita discutir dudas, indagar críticamente, reflexionar, compartir significados subjetivos, expresar frustraciones, sentirse escuchado y escuchada, y negociar y construir nuevos significados.

Para establecer estas dinámicas, las profesoras del curso se mostraron empáticas, creativas, flexibles y ocurrentes, sobre todo cuando se trataba de abordar la resistencia vinculada a las cuestiones relacionadas con el género. Se esforzaron por potenciar la comunicación de los y las participantes, sin juzgarlos, ayudando a adoptar una perspectiva de género y permitiéndoles iniciar un proceso de aprendizaje y cambio reflexivo.

Tabla 2. Descripción de las sesiones, objetivos y actividades de las sesiones del curso "Perspectiva de Género"

\begin{tabular}{|c|c|c|}
\hline Sesión & Objetivo & Dinámicas \\
\hline \multicolumn{3}{|c|}{ Módulo 1: Derechos de las mujeres: origen y perspectivas } \\
\hline $\begin{array}{l}\text { Sesión 1: } \\
\text { Origen de la } \\
\text { reivindicación de la } \\
\text { igualdad de género }\end{array}$ & $\begin{array}{l}\text { - Presentación del curso. } \\
\text { - Favorecer el conocimiento } \\
\text { del marco internacional } \\
\text { sobre los derechos de las } \\
\text { mujeres, profundizando en los } \\
\text { objetivos de la Agenda } 2030 . \\
\end{array}$ & $\begin{array}{l}\text { Actividad 1: Presentación de las } \\
\text { docentes y participantes. } \\
\text { Actividad 2: ¿Qué sabes de la Agenda } \\
2030 \text { ? }\end{array}$ \\
\hline $\begin{array}{l}\text { Sesión 2: } \\
\text { Origen de la } \\
\text { reivindicación de la } \\
\text { igualdad de género }\end{array}$ & $\begin{array}{l}\text { - Ofrecer un análisis de la } \\
\text { situación de la mujer en el } \\
\text { mundo a través del Woman } \\
\text { Stats Maps. }\end{array}$ & $\begin{array}{l}\text { Actividad 3: Debate sobre la } \\
\text { información contenida en los Women } \\
\text { Stats Map. }\end{array}$ \\
\hline $\begin{array}{l}\text { Sesión 3: } \\
\text { Evolución histórica } \\
\text { de las demandas } \\
\text { feministas }\end{array}$ & $\begin{array}{l}\text { - Favorecer el análisis de la } \\
\text { evolución histórica de las } \\
\text { demandas feministas. } \\
\text { - Ofrecer una visión crítica del } \\
\text { feminismo español. }\end{array}$ & $\begin{array}{l}\text { Actividad 4: ¿Qué hacemos por la } \\
\text { Igualdad de Género? } \\
\text { Actividad 5: ¿Por qué creéis que los } \\
\text { movimientos se denominan olas? } \\
\text { Actividad 6: Sufragio femenino en el } \\
\text { mundo. }\end{array}$ \\
\hline \multicolumn{3}{|c|}{ Módulo 2: ¿Qué es el género? } \\
\hline $\begin{array}{l}\text { Sesión 4: } \\
\text { ¿Sexo o género, } \\
\text { o ninguno de los } \\
\text { dos? }\end{array}$ & $\begin{array}{l}\text { - Diferenciar conceptos básicos } \\
\text { como sexo y género para } \\
\text { comprender las políticas de } \\
\text { inclusión social actuales. } \\
\text { - Análisis de la construcción } \\
\text { social de género. } \\
\text { - Análisis de los procesos de } \\
\text { socialización del poder. }\end{array}$ & $\begin{array}{l}\text { Actividad 7: Reflexión en torno al } \\
\text { género a partir de los contenidos } \\
\text { videográficos "Dibujando en el } \\
\text { género". } \\
\text { Actividad 8: ¿Hasta qué punto crees } \\
\text { que tiene que ver el género con la } \\
\text { conciliación? } \\
\text { Actividad 9: El poder, ¿cuestión de } \\
\text { género? } \\
\text { Actividad 10: Cuestionando los mitos } \\
\text { en torno a la división social del trabajo. }\end{array}$ \\
\hline
\end{tabular}




\begin{tabular}{|c|c|c|}
\hline Sesión & Objetivo & Dinámicas \\
\hline $\begin{array}{l}\text { Sesión 5: } \\
\text { Incorporando las } \\
\text { herramientas que } \\
\text { necesitamos para } \\
\text { analizar la realidad }\end{array}$ & $\begin{array}{l}\text { - Reconocer la medida del } \\
\text { tiempo como una herramienta } \\
\text { útil y objetiva para evidenciar } \\
\text { las desigualdades de género. } \\
\text { - Análisis de las causas macro y } \\
\text { micro sociales de la desigual } \\
\text { distribución del uso del } \\
\text { tiempo. } \\
\text { - Introducción y análisis del } \\
\text { constructo de la conciliación } \\
\text { y la corresponsabilidad. } \\
\end{array}$ & $\begin{array}{l}\text { Actividad 11: ¿Creéis que son } \\
\text { importantes los estudios del tiempo? } \\
\text { Actividad 12: Análisis de los modelos } \\
\text { de centralidad social. } \\
\text { Actividad 13: ¿Qué sucede en España } \\
\text { cuando una mujer no puede conciliar? } \\
\text { Actividad 14: ¿Qué podemos hacer } \\
\text { para fomentar en nuestros hogares la } \\
\text { igualdad de género? }\end{array}$ \\
\hline $\begin{array}{l}\text { Sesión 6: } \\
\text { Incorporando las } \\
\text { herramientas que } \\
\text { necesitamos para } \\
\text { analizar la realidad }\end{array}$ & $\begin{array}{l}\text { - Revisión de estadísticas y } \\
\text { estudios sobre la evolución } \\
\text { y repercusiones del uso del } \\
\text { tiempo. } \\
\text { - Análisis de las consecuencias } \\
\text { del uso desigual de tiempo } \\
\text { entre hombres y mujeres. }\end{array}$ & $\begin{array}{l}\text { Actividad 15: ¿Cómo crees que puedes } \\
\text { colaborar en evitar la desigualdad en } \\
\text { tu vida? } \\
\text { Actividad 16: ¿Consideras que es } \\
\text { importante cuestionarse (todo) desde la } \\
\text { perspectiva de género? } \\
\text { Actividad 17: ¡Sé parte del cambio que } \\
\text { estabas esperando! }\end{array}$ \\
\hline $\begin{array}{l}\text { Sesión 7: } \\
\text { Conciliación y } \\
\text { corresponsabilidad }\end{array}$ & $\begin{array}{l}\text { - Favorecer un análisis y } \\
\text { reflexión sobre los ámbitos } \\
\text { (laboral, familiar, personal } \\
\text { y social) que vertebran la } \\
\text { conciliación y dan lugar a la } \\
\text { corresponsabilidad. }\end{array}$ & $\begin{array}{l}\text { Actividad 18: Siempre hablamos } \\
\text { de } 4 \text { pilares fundamentales para la } \\
\text { conciliación, ¿sabes cuáles son? } \\
\text { Actividad 19: ¿Qué argumentos a } \\
\text { favor de la conciliación se te ocurren? }\end{array}$ \\
\hline $\begin{array}{l}\text { Sesión 8: } \\
\text { Conciliación y } \\
\text { corresponsabilidad }\end{array}$ & $\begin{array}{l}\text { - Desarrollar una actitud } \\
\text { orientada a favorecer las } \\
\text { buenas prácticas hacia una } \\
\text { mayor cohesión social. } \\
\text { - Necesidades de las familias. } \\
\text { - Beneficios de la conciliación. }\end{array}$ & $\begin{array}{l}\text { Actividad 20: ¿Se te ocurren algunas } \\
\text { medidas para llevar a cabo una correcta } \\
\text { corresponsabilidad? } \\
\text { Actividad 21: ¿Crees que es fácil } \\
\text { alcanzar la corresponsabilidad en todos } \\
\text { los países del mundo? }\end{array}$ \\
\hline \multicolumn{3}{|c|}{ Módulo 3: Género en el desarrollo } \\
\hline $\begin{array}{l}\text { Sesión 9: } \\
\text { ¿Qué es el } \\
\text { desarrollo? }\end{array}$ & $\begin{array}{l}\text { - Consideración de } \\
\text { las estrategias de } \\
\text { empoderamiento femenino } \\
\text { en el ámbito productivo, } \\
\text { reproductivo, comunitario, de } \\
\text { acceso a la igualdad, justicia, } \\
\text { acceso y control de los } \\
\text { recursos y del poder. } \\
\text { - Afianzar el enfoque de género } \\
\text { en el desarrollo sostenible. } \\
\end{array}$ & $\begin{array}{l}\text { Actividad 22: Ahora que conoces } \\
\text { los cuatro ámbitos, ¿Cómo podemos } \\
\text { fomentar la conciliación? } \\
\text { Actividad 23: La vida laboral de la } \\
\text { mujer española. }\end{array}$ \\
\hline
\end{tabular}


Fomento de la participación de personas mayores en Perspectiva de Género: una experiencia con agentes activos de cambio social

\begin{tabular}{|l|l|l|}
\hline \multicolumn{1}{|c|}{ Sesión } & \multicolumn{1}{|c|}{ Objetivo } & \multicolumn{1}{c|}{ Dinámicas } \\
\hline $\begin{array}{l}\text { Sesión 10: } \\
\text { ¿Por qué género en } \\
\text { el desarrollo? }\end{array}$ & $\begin{array}{l}\text { Beneficios de una buena } \\
\text { gestión del tiempo. }\end{array}$ & $\begin{array}{l}\text { Actividad 24: Mujer y liderazgo. } \\
\text { Análisis de material video gráfico. } \\
\text { Actividad 25: Debate sobre la } \\
\text { Odopción de la perspectiva de género. } \\
\end{array}$ \\
$\begin{array}{l}\text { Oénero en el desarrollo. } \\
\text { Estrategias para la prevención } \\
\text { de la violencia contra las } \\
\text { mujeres. }\end{array}$ & \\
\hline
\end{tabular}

Fuente: Elaboración propia (2020)

\section{4. "Perspectiva de Género": evaluación del curso}

Consideramos que para analizar si la actividad ha sido eficaz y alcanza sus objetivos es necesario hacer una evaluación de la misma y reflexionar sobre los resultados. Monitorizar y hacer un seguimiento de los resultados nos permitirá mejorar las actividades, dinámicas y estrategias a la hora de abordar la dinámica de posibles futuros cursos.

En esta ocasión, los elementos que nos interesa conocer hacen referencia a los siguientes puntos:

1. si la actividad está bien planificada y se realiza en un formato adecuado (tanto en términos de contenidos como de dinámicas);

2. si satisface las necesidades de los y las participantes;

3. y si está en línea con los objetivos de aprendizaje previamente establecidos.

Para llevar a cabo este análisis, se recogió y analizó información a través de un cuestionario elaborado por las autoras que incluye ítems cuantitativos con escalas tipo Likert de 5 puntos, e ítems cualitativos. En el cuestionario se recoge información sobre características personales de los y las participantes, sobre el desarrollo de la actividad, su organización, su aplicabilidad y utilidad, con sus puntos fuertes y débiles.

\subsubsection{Descripción de las personas participantes en el curso}

En el curso participaron 45 personas, de las cuáles 22 contestaron el cuestionario (ver tabla 3). Las personas del curso que participaron en la encuesta tienen una edad media de 63,95 años (DT: 4.68), entre 51 y 72 años. El 59,1 \% son mujeres, mientras que el 40,9 $\%$ son hombres. El 15,8 \% de las personas participantes tiene un nivel educativo básico, un $47,4 \%$ un nivel educativo medio y un $36,8 \%$ tiene un nivel educativo superior. El $100 \%$ de los participantes son personas jubiladas o pensionistas. 
Tabla 3. Características sociodemográficas de la muestra

\begin{tabular}{|lc|}
\hline \multicolumn{1}{|c|}{ Edad (M, DT) - Min/Max } & $\mathbf{6 3 . 9 5}(\mathbf{4 . 6 8 )}$ - 51/72 \\
\hline Educación (\%) & $0 \%$ \\
\hline Sin estudios & $15,8 \%$ \\
\hline Estudios básicos & $47,4 \%$ \\
\hline Estudios medios & $36,8 \%$ \\
\hline Estudios superiores & \\
\hline Género (\%) & $59,1 \%$ \\
\hline Mujer & $40,9 \%$ \\
\hline Hombre & \\
\hline Situación laboral previa a la jubilación (\%) & $13,6 \%$ \\
\hline Educación & $22,7 \%$ \\
\hline Administración & $9,1 \%$ \\
\hline Trabajo doméstico no remunerado & $18,2 \%$ \\
\hline Empresa/banca & $9,1 \%$ \\
\hline Pensionista & $22,7 \%$ \\
\hline Autónomo & \\
\hline
\end{tabular}

Fuente: Elaboración propia (2020)

\subsubsection{Satisfacción de los y las participantes en el curso "Perspectiva de Género"}

En general, los/las 22 participantes que contestaron la encuesta valoran la organización del curso como buena y ejemplar. En concreto, tal como se puede observar en la tabla 4, el 95,3\% de las personas consideran que la actividad está organizada lógicamente y que los objetivos están definidos claramente $(80,9 \%)$.

Tabla 4. Respuestas de asistentes al curso "Perspectiva de Género" a la organización del curso $(\mathrm{N}=\mathbf{2 2})$

\begin{tabular}{|c|c|c|c|c|c|c|}
\hline \multicolumn{7}{|c|}{ Porcentajes } \\
\hline Organización & \begin{tabular}{|c|} 
No \\
satisfactoria
\end{tabular} & Satisfactoria & Buena & Ejemplar & $\mathrm{n}$ & Media/DT \\
\hline $\begin{array}{l}\text { La actividad está organizada } \\
\text { lógicamente }\end{array}$ & & 4.8 & 52.4 & 42.9 & 21 & $3.38(.59)$ \\
\hline $\begin{array}{l}\text { Los objetivos de la actividad están } \\
\text { definidos claramente }\end{array}$ & & 9.1 & 40.9 & 40 & 22 & $3.41 / .66$ \\
\hline $\begin{array}{l}\text { Las actividades planteadas favorecen } \\
\text { la reflexión sobre la perspectiva de } \\
\text { género }\end{array}$ & & 9.1 & 36.4 & 54.5 & 22 & $3.45 / .67$ \\
\hline
\end{tabular}


Fomento de la participación de personas mayores en Perspectiva de Género: una experiencia con agentes activos de cambio social

\begin{tabular}{|c|c|c|c|c|c|c|}
\hline \multicolumn{7}{|c|}{ Porcentajes } \\
\hline Organización & $\begin{array}{c}\text { No } \\
\text { satisfactoria }\end{array}$ & Satisfactoria & Buena & Ejemplar & $\mathrm{n}$ & Media/DT \\
\hline $\begin{array}{l}\text { Las clases incluyen las ideas } \\
\text { principales del feminismo y de la } \\
\text { perspectiva de género }\end{array}$ & & 4.8 & 38.1 & 57.1 & 21 & $3.52 / .60$ \\
\hline $\begin{array}{l}\text { El tiempo empleado para esta } \\
\text { temática en el curso es }\end{array}$ & 5.6 & 22.2 & 50 & 22.2 & 18 & $2.89 / .83$ \\
\hline
\end{tabular}

Fuente: Elaboración propia (2020)

Los/las participantes valoran muy positivamente que las actividades planteadas favorezcan la reflexión sobre la Perspectiva de Género y que las clases incluyen las ideas principales del Feminismo y de la Perspectiva de Género. Con respecto al tiempo empleado para esta temática en el curso, las respuestas son algo más variadas. Algunos/as participantes comentan que el tiempo empleado en el curso es insuficiente (ver tabla 4), aunque el $90 \%$ de los participantes consideran que el tiempo empleado es satisfactorio.

En general, los/las participantes del curso valoran muy positivamente los contenidos del curso. Tal como indican los datos (ver tabla 5) los/las asistentes valoran que el curso haya favorecido la identificación de los procesos individuales, sociales y culturales que causan y mantienen las diferencias y desigualdades en función del sexo y género (54.4\%). 
Tabla 5. Respuestas de los/las asistentes al curso "Perspectiva de Género" al contenido del curso $(\mathrm{N}=\mathbf{2 2})$

\begin{tabular}{|c|c|c|c|c|c|c|}
\hline \multirow[b]{2}{*}{ Contenido } & \multicolumn{4}{|c|}{ Porcentajes } & \multirow[b]{2}{*}{$\mathrm{n}$} & \multirow[b]{2}{*}{ Media/DT } \\
\hline & $\begin{array}{c}\text { No } \\
\text { satisfactoria } \\
\end{array}$ & Satisfactoria & Buena & Ejemplar & & \\
\hline $\begin{array}{l}\text { El curso me ha permitido conocer } \\
\text { mejor la situación de la mujer en el } \\
\text { mundo y en nuestro contexto social } \\
\text { y familiar. }\end{array}$ & & 4.7 & 52.4 & 42.9 & 21 & $3.38 / .59$ \\
\hline $\begin{array}{l}\text { El curso ha fomentado una } \\
\text { sensibilidad por los derechos } \\
\text { humanos y la igualdad de género. }\end{array}$ & & 9.1 & 40.9 & 50 & 22 & $3.41 / .66$ \\
\hline $\begin{array}{l}\text { El curso ha favorecido la } \\
\text { identificación de los procesos } \\
\text { individuales, sociales y culturales } \\
\text { que causan y mantienen las } \\
\text { diferencias y desigualdades en } \\
\text { función del sexo y género. }\end{array}$ & & 9.1 & 36.4 & 54.5 & 22 & $3.45 / .67$ \\
\hline $\begin{array}{l}\text { El curso ha favorecido el } \\
\text { reconocimiento de las consecuencias } \\
\text { derivadas de las desigualdades de } \\
\text { género. }\end{array}$ & & & 47.6 & 52.4 & 21 & $3.52 / .51$ \\
\hline $\begin{array}{l}\text { El curso ha fomentado la reflexión } \\
\text { en torno a cómo el sistema de género } \\
\text { determina e influye las relaciones } \\
\text { entre las personas. }\end{array}$ & & 9.1 & 36.4 & 54.5 & 22 & $3.45 / .67$ \\
\hline $\begin{array}{l}\text { El curso ha fomentado la reflexión } \\
\text { en torno a cómo el sistema de } \\
\text { género influye en el desarrollo de la } \\
\text { propia identidad y las preferencias } \\
\text { individuales. }\end{array}$ & & 4.8 & 38.1 & 57.1 & 21 & $3.52 / .60$ \\
\hline $\begin{array}{l}\text { El curso ha favorecido el análisis } \\
\text { de las razones que explican las } \\
\text { diferencias en la promoción laboral } \\
\text { de hombres y mujeres. }\end{array}$ & & 9.2 & 54.4 & 36.4 & 22 & $3.27 / .63$ \\
\hline $\begin{array}{l}\text { El curso ha propiciado el } \\
\text { reconocimiento de los conceptos } \\
\text { básicos sobre las desigualdades en } \\
\text { relación a la conciliación de la vida } \\
\text { personal, familiar y laboral. }\end{array}$ & & & 42.9 & 57.1 & 21 & $3.57 / .50$ \\
\hline $\begin{array}{l}\text { El curso ha promovido la } \\
\text { importancia de la nueva estrategia de } \\
\text { corresponsabilidad. }\end{array}$ & & & 36.4 & 63.6 & 22 & $3.64 / .49$ \\
\hline
\end{tabular}


Fomento de la participación de personas mayores en Perspectiva de Género: una experiencia con agentes activos de cambio social

\begin{tabular}{|c|c|c|c|c|c|c|}
\hline \multirow[b]{2}{*}{ Contenido } & \multicolumn{4}{|c|}{ Porcentajes } & \multirow[b]{2}{*}{$\mathrm{n}$} & \multirow[b]{2}{*}{ Media/DT } \\
\hline & $\begin{array}{c}\text { No } \\
\text { satisfactoria }\end{array}$ & Satisfactoria & Buena & Ejemplar & & \\
\hline $\begin{array}{l}\text { El curso ha favorecido mi } \\
\text { conocimiento de las medidas, los } \\
\text { derechos y recursos de los que se } \\
\text { dispone para conseguir una mayor } \\
\text { calidad de vida al tener que conciliar } \\
\text { las tareas del espacio privado y } \\
\text { público. }\end{array}$ & & 9.1 & 50 & 40.9 & 22 & $3.32 / .64$ \\
\hline $\begin{array}{l}\text { El curso ha fomentado un análisis } \\
\text { objetivo y crítico de la perspectiva de } \\
\text { género, basado en datos estadísticos } \\
\text { y globales de las problemáticas. }\end{array}$ & & 10 & 40 & 50 & 20 & $3.40 / .68$ \\
\hline
\end{tabular}

Fuente: Elaboración propia (2020)

Asimismo, los/las participantes valoran muy positivamente que se haya fomentado la reflexión en torno a cómo el sistema de género influye en el desarrollo de la propia identidad y las preferencias individuales $(57.1 \%)$; valoran, además, muy positivamente que el curso haya propiciado el reconocimiento de los conceptos básicos sobre las desigualdades en relación a la conciliación de la vida personal, familiar y laboral $(57.1 \%)$; así como que haya promovido la importancia de la nueva estrategia de corresponsabilidad $(63.6 \%)$.

En general, los/las asistentes al curso valoran positivamente poder aplicar los contenidos impartidos en el curso en su vida cotidiana y recomendarían este curso (ver tabla 6). En concreto, valoran muy positivamente que en el curso se hayan discutido los diferentes temas relacionados con la igualdad de género desde una perspectiva creativa y crítica $(68.2 \%)$, y que se haya permitido hablar sobre las diferentes problemáticas relacionadas con el género de una manera constructiva (52.4\%). 
Tabla 6. Respuestas de los/las asistentes al curso "Perspectiva de Género" a la aplicabilidad y utilidad de los contenidos del curso $(\mathrm{N}=\mathbf{2 2})$

\begin{tabular}{|c|c|c|c|c|c|c|}
\hline \multirow[b]{2}{*}{ Aplicabilidad y utilidad } & \multicolumn{4}{|c|}{ porcentaje } & \multirow[b]{2}{*}{$\mathrm{n}$} & \multirow[b]{2}{*}{ Media/DT } \\
\hline & $\begin{array}{c}\text { No } \\
\text { satisfactoria }\end{array}$ & Satisfactoria & Buena & Ejemplar & & \\
\hline $\begin{array}{l}\text { En el curso se han discutido los } \\
\text { diferentes temas relacionados con } \\
\text { la igualdad de género desde una } \\
\text { perspectiva creativa, crítica. }\end{array}$ & & 4.5 & 27.3 & 68.2 & 22 & $3.59 / .73$ \\
\hline $\begin{array}{l}\text { Las actividades e ideas planteadas } \\
\text { en el curso me resultan útiles para } \\
\text { aplicar en mi vida. }\end{array}$ & & & 61.9 & 38.1 & 21 & $3.38 / .49$ \\
\hline $\begin{array}{l}\text { Creo que las actividades han } \\
\text { contribuido a mi desarrollo personal }\end{array}$ & & 5.2 & 63.2 & 31.6 & 19 & $3.26 / .56$ \\
\hline $\begin{array}{l}\text { Recomendaría este curso a otros } \\
\text { compañeros/as }\end{array}$ & & & 33.3 & 66.7 & 21 & $3.67 / .48$ \\
\hline $\begin{array}{l}\text { Las actividades y contenidos del } \\
\text { curso han contribuido a reconocer } \\
\text { mejor las desigualdades de género }\end{array}$ & & 9.1 & 31.8 & 59.1 & 22 & $3.5 / .67$ \\
\hline $\begin{array}{l}\text { El curso ha fomentado mi } \\
\text { visión crítica en relación a las } \\
\text { desigualdades de género. }\end{array}$ & & 42.8 & 52.4 & 42.9 & 21 & $3.38 / .59$ \\
\hline $\begin{array}{l}\text { El curso me ha permitido hablar } \\
\text { sobre las diferentes problemáticas } \\
\text { relacionadas con el género de una } \\
\text { manera constructiva }\end{array}$ & & & 4.7 .6 & 52.4 & 21 & $3.52 / .51$ \\
\hline
\end{tabular}

Fuente: Elaboración propia (2020)

En resumen, los y las participantes en el curso son personas mayores que han elegido voluntariamente acudir al curso y se sienten satisfechos/as con él. Valoran muy positivamente que la actividad formativa está bien planificada y que se realiza en un formato adecuado, cumpliéndose con los objetivos de aprendizaje previamente establecidos. Consideran que las actividades han favorecido la reflexión creativa y constructiva sobre la Perspectiva de Género y sobre cómo el sistema de género influye en el desarrollo de la propia identidad y las preferencias individuales. Asimismo, los y las participantes consideran que la reflexión y el diálogo les ha ayudado a convertirse en personas más activas y responsables de las decisiones de su vida, ha favorecido la necesidad de replantear su propio funcionamiento personal y familiar, y de incorporar una estrategia de corresponsabilidad en su vida cotidiana. Algunos/as participantes ponen de manifiesto "la capacidad de las docentes para tratar el tema", así como su capacidad de "ayudar a analizar el propio comportamiento y a reflexionar sobre los temas tratados". Los y las participantes hacen notar la "dificultad del tema" y "la necesidad de trascender de las historias personales de desigualdad para alcanzar una visión más global y social del tema”. 
Fomento de la participación de personas mayores en Perspectiva de Género: una experiencia con agentes activos de cambio social

\subsubsection{Diferencias entre hombres y mujeres con respecto a la valoración del curso "Perspectiva de Género"}

Nuestra observación como docentes del curso es que el debate en torno al género suele despertar ciertas controversias y resistencias entre los y las participantes. Es un tema que genera diversas reacciones emocionales, y, en cualquier caso, supone también un reto cognitivo, puesto que los y las participantes, ante la evidencia de los datos, ven la necesidad de cuestionar y reelaborar sus creencias para adaptarse a su entorno.

En el presente apartado se analiza si existen diferencias entre hombres y mujeres en relación a la valoración del curso 6 su satisfacción con los contenidos y dinámicas ofrecidas, así como la aplicabilidad de los mismos.

Tal como se observa en la tabla 7, en general, no se observan diferencias significativas entre hombres y mujeres en relación a la valoración de la organización del curso. No obstante, se observa una diferencia significativa entre hombres y mujeres en relación al ítem 3, en el sentido de que las mujeres valoran más positivamente el hecho de que las actividades planteadas favorecen la reflexión sobre la Perspectiva de Género.

Tabla 7. Diferencias entre hombres y mujeres con respecto a su valoración de la organización del curso. Resultados Pruebas t- muestras independientes

\begin{tabular}{|l|c|c|c|c|c|}
\hline Organización & Mujeres & & Hombres & & \\
\hline 1. La actividad está organizada lógicamente. & 3,54 &, 51 & 3,13 &, 64 &, 626 \\
\hline $\begin{array}{l}\text { 2. Los objetivos de la actividad está definidos } \\
\text { claramente }\end{array}$ & 3,62 &, 50 & 3,11 &, 78 &, 382 \\
\hline $\begin{array}{l}\text { 3. Las actividades planteadas favorecen la reflexión } \\
\text { sobre la perspectiva de género }\end{array}$ & 3,62 &, 50 & 3,33 &, 86 &, 025 \\
\hline $\begin{array}{l}\text { 4. Las clases incluyen las ideas principales del } \\
\text { feminismo y de la perspectiva de género. }\end{array}$ & 3,54 &, 51 & 3,38 &, 74 &, 140 \\
\hline $\begin{array}{l}\text { 5. El tiempo empleado para esta temática en el curso es } \\
\text { Total }\end{array}$ & 3,20 &, 78 & 2,50 &, 75 &, 936 \\
\hline
\end{tabular}

Fuente: Elaboración propia (2020)

En relación a los contenidos impartidos en el curso, tampoco se observan diferencias significativas en la valoración de hombres y mujeres a excepción del ítem 9, en el que se observa una diferencia tendencial entre hombres y mujeres (ver tabla 8). Las mujeres, en comparación con los hombres, consideran que el curso ha promovido la importancia de una nueva estrategia de conciliación y corresponsabilidad. 
Tabla 8. Diferencias entre hombres y mujeres con respecto a su valoración de los contenidos del curso. Resultados Pruebas t- muestras independientes

\begin{tabular}{|c|c|c|c|c|c|}
\hline \multirow{2}{*}{ Contenidos del curso } & Mujeres & & Hombres & & \\
\hline & Media/ & DT & Media & DT & sig \\
\hline $\begin{array}{l}\text { 1. El curso me ha permitido conocer mejor la situación } \\
\text { de la mujer en el mundo y en nuestro contexto social y } \\
\text { familiar. }\end{array}$ & 3,62 &, 50 & 3,00 &, 53 & , 109 \\
\hline $\begin{array}{l}\text { 2. El curso ha fomentado una sensibilidad por los } \\
\text { derechos humanos y la igualdad de género. }\end{array}$ & 3,54 &, 51 & 3,22 & ,83 &, 091 \\
\hline $\begin{array}{l}\text { 3. El curso ha favorecido la identificación de los } \\
\text { procesos individuales, sociales y culturales que causan } \\
\text { y mantienen las diferencias y desigualdades en función } \\
\text { del sexo y género. }\end{array}$ & 3,85 &, 37 & 2,89 & ,60 & ,370 \\
\hline $\begin{array}{l}\text { 4. El curso ha favorecido el reconocimiento de las } \\
\text { consecuencias derivadas de las desigualdades de } \\
\text { género. }\end{array}$ & 3,54 &, 51 & 3,50 &, 53 &, 838 \\
\hline $\begin{array}{l}\text { 5. El curso ha fomentado la reflexión en torno a cómo } \\
\text { el sistema de género determina e influye las relaciones } \\
\text { entre las personas. }\end{array}$ & 3,69 & ,48 & 3,11 & ,78 & ,254 \\
\hline $\begin{array}{l}\text { 6. El curso ha fomentado la reflexión en torno a cómo } \\
\text { el sistema de género influye en el desarrollo de la } \\
\text { propia identidad y las preferencias individuales. }\end{array}$ & 3,62 &, 50 & 3,38 & ,74 &, 140 \\
\hline $\begin{array}{l}\text { 7. El curso ha favorecido el análisis de las razones que } \\
\text { explican las diferencias en la promoción laboral de } \\
\text { hombres y mujeres. }\end{array}$ & 3,46 &, 51 & 3,00 & ,70 &, 721 \\
\hline $\begin{array}{l}\text { 8. El curso ha propiciado el reconocimiento de los } \\
\text { conceptos básicos sobre las desigualdades en relación } \\
\text { a la conciliación de la vida personal, familiar y laboral. }\end{array}$ & 3,69 & ,48 & 3,38 &, 5 &, 575 \\
\hline $\begin{array}{l}\text { 9. El curso ha promovido la importancia de la nueva } \\
\text { estrategia de corresponsabilidad. }\end{array}$ & 3,92 &, 27 & 3,22 & ,44 &, 063 \\
\hline $\begin{array}{l}\text { 10.El curso ha favorecido mi conocimiento de las } \\
\text { medidas, los derechos y recursos de los que se dispone } \\
\text { para conseguir una mayor calidad de vida al tener que } \\
\text { conciliar las tareas del espacio privado y público. }\end{array}$ & 3,54 &, 51 & 3,00 & ,70 & ,721 \\
\hline $\begin{array}{l}\text { 11. El curso ha fomentado un análisis objetivo y } \\
\text { crítico de la perspectiva de género, basado en datos } \\
\text { estadísticos y globales de las problemáticas. }\end{array}$ & 3,38 & ,65 & 3,43 & ,7 &, 552 \\
\hline Total & 3,62 &, 24 & 3,29 &, 50 &, 194 \\
\hline
\end{tabular}

Fuente: Elaboración propia (2020)

Por último, y en relación a la aplicación práctica de los contenidos del curso en la vida diaria, las mujeres valoran de forma significativa el hecho de que en el curso se han discutido los diferentes temas relacionados con la igualdad de género desde una perspectiva 
Fomento de la participación de personas mayores en Perspectiva de Género: una experiencia con agentes activos de cambio social

creativa y crítica (ver tabla 9). En cuanto al resto de ítems, no se observan diferencias significativas entre los hombres y las mujeres participantes.

Tabla 9. Diferencias entre hombres y mujeres con respecto a su valoración de la aplicación práctica de los contenidos del curso. Resultados Pruebas t- muestras independientes

\begin{tabular}{|c|c|c|c|c|c|}
\hline \multirow{2}{*}{ Aplicabilidad y utilidad } & Mujeres & & Hombres & & \\
\hline & Media & DT & Media & DT & sig \\
\hline $\begin{array}{l}\text { En el curso se han discutido los diferentes temas } \\
\text { relacionados con la igualdad de género desde una } \\
\text { perspectiva creativa, crítica. }\end{array}$ & 3,85 & ,37 & 3,22 & ,97 & ,039 \\
\hline $\begin{array}{l}\text { Las actividades e ideas planteadas en el curso me } \\
\text { resultan útiles para aplicar en mi vida. }\end{array}$ & 3,31 &, 48 & 3,50 &, 53 & ,276 \\
\hline $\begin{array}{l}\text { Creo que las actividades han contribuido a mi } \\
\text { desarrollo personal }\end{array}$ & 3,36 &, 50 & 3,13 & ,64 &, 858 \\
\hline Recomendaría este curso a otros compañeros/as & 3,77 & ,43 & 3,50 &, 53 &, 102 \\
\hline $\begin{array}{l}\text { Las actividades y contenidos del curso han contribuido } \\
\text { a reconocer mejor las desigualdades de género }\end{array}$ & 3,77 & ,43 & 3,11 &, 78 &, 129 \\
\hline $\begin{array}{l}\text { El curso ha fomentado mi visión crítica en relación a } \\
\text { las desigualdades de género. }\end{array}$ & 3,38 & ,65 & 3,38 &, 51 & ,347 \\
\hline $\begin{array}{l}\text { El curso me ha permitido hablar sobre las diferentes } \\
\text { problemáticas relacionadas con el género de una } \\
\text { manera constructiva }\end{array}$ & 3,54 &, 51 & 3,50 & ,53 &, 838 \\
\hline Total & 3,53 & ,33 & 3,39 &, 40 &, 574 \\
\hline
\end{tabular}

Fuente: Elaboración propia (2020)

En general, tal como se desprende de los datos, no existen grandes diferencias entre los hombres y las mujeres del grupo en relación a su satisfacción del curso y valoración de su utilidad. No obstante, sí que se observan diferencias en relación a la percepción de aquellas actividades que suponen una reflexión para la introducción de una Perspectiva de Género y que suponen un cuestionamiento de sus propias situaciones, actitudes y comportamientos. Las mujeres valoran estas actividades más positivamente que los hombres del grupo y se muestran más proclives a tratar estos temas de forma creativa y crítica. Asimismo, son las mujeres del grupo las que se muestran más contundentes a la hora de considerar que el curso ha promovido la importancia de considerar una nueva estrategia de corresponsabilidad.

\subsection{Conclusión}

A grandes rasgos, consideramos que el curso "Perspectiva de Género" de UNISOCIETAT ha favorecido la sensibilización en Educación para el Desarrollo y la Ciudadanía Global (EpDyCG) sobre las cuestiones relativas a la igualdad entre los géneros en diversas esferas: política, laboral, familiar e individual. El curso ha contribuido a generar una mayor consciencia, orientando a los y las participantes a reducir la resistencia a la 
incorporación de la igualdad de género, al tiempo que ha potenciado los conocimientos y aptitudes sobre la forma de incorporar la Perspectiva de Género en la organización cotidiana del tiempo.

Además, en línea con el pensamiento de Hodder (2010), entendemos a los y las participantes de esta formación como agentes de cambio social especialmente pertinentes para el desarrollo. Para ello, se han dedicado esfuerzos por interpretar muchas de las contribuciones de las personas mayores a lo largo de todas las sesiones. Ellas y ellos han fijado su mirada en determinadas referencias personales para devolverlas a la ciudadanía e invitarnos a reflexionar sobre estas manifestaciones de una solidaridad colectiva y diacrónica, de cómo aquellas gentes en el pasado hicieron o crearon cosas que han contribuido a nuestro bienestar, pero que — sobre todo - son manifestaciones del empuje personal y colectivo de tantas gentes por mejorar sus condiciones de vida y enriquecerse con la creatividad de otros.

Las referencias simbólicas que cada comunidad humana es capaz de identificar, generar y recrear, son fundamentales para interpretar el continuado esfuerzo de personas, instituciones y pueblos por desarrollarse humanamente y en armonía con su entorno. Es decir, muchos de los testimonios de personas mayores son interpretables ahora como referencias de los logros que a lo largo de siglos han conseguido las comunidades humanas para nutrir su hambre y su dignidad. Se trata de ejercer nuestro derecho colectivo al desarrollo, que incluye nuestros derechos culturales (Benneoune, 2016).

Es más, mirado así, podemos pensar que el patrimonio cultural no solo es lo que heredamos, sino que es también lo que nosotros y nosotras hoy somos capaces de identificar porque consideramos que es importante para entender nuestro presente y dotar de argumentos cívicos nuestra adhesión personal y colectiva al desarrollo humano sostenible desde la diversidad (Cabrero, 2006).

Desde este enfoque y con la ejecución de este curso-taller formativo, hemos realizado un viaje de ida y vuelta: hay quienes se han inscrito atraídos por la idea de conocer mejor la Universitat de València; otras personas han participado con la inquietud de entender mejor qué es esto de la Agenda 2030; y/u otras deseaban no estar solas en su hogar. En estas sesiones, dentro del aula y en las casas de cada uno de los y las participantes, se han producido relaciones simbióticas entre las diferentes aspiraciones, altamente valoradas en las evaluaciones. De alguna manera, podemos decir que humanizar la enseñanza superior en todos los ámbitos de trabajo, de estudio, de investigación o de docencia, no solo se limita a regenerar los discursos, sino (como en este caso) a reapropiarse de los referentes patrimoniales y re-usarlos como material eficaz en la generación de impactos y en la transformación de las maneras de pensar nuestra sociedad: la local y la global.

En definitiva, como invita Martínez-Usarralde (2011), existe un camino a recorrer que fortalece los resultados del aprendizaje a través de lo que sentimos y pensamos. A nuestra consideración, un instrumento eficaz para ese "sentipensar" es el patrimonio cultural. También queremos participar de esa universalidad de las expresiones patrimoniales y 
Fomento de la participación de personas mayores en Perspectiva de Género: una experiencia con agentes activos de cambio social

culturales que nos permita compartir una conciencia de ciudadanía global para la que queremos estar preparados/as y desde donde relanzar nuestra capacidad de fomentar la igualdad de género, nuestra solidaridad, nuestro compromiso y nuestro reconocimiento a la inmensa diversidad cultural, entendida como la manera de resolver y aportar soluciones para llevar una vida digna para todas las personas.

\subsection{Referencias bibliográficas}

Acker, J. (1990). "Hierarchies, jobs, bodies: A theory of gendered organizations". Gender \& Society, 4(2), 139-158.

Amorós, C. (2000). Tiempo de Feminismo. Sobre feminismo, proyecto ilustrado y postmodernidad. Madrid: Cátedra.

Artigas, B. (2015). La contribución de la universidad al desarrollo humano, bienestar y ciudadanía global: una mirada cualitativa. (Tesis doctoral). Palma de Mallorca: Universitat de les Illes Balears.

Beauvoir, S. de (2017). El segundo sexo. Madrid: Cátedra.

Bennoune, K. (2016). Informe de la Relatora Especial sobre los Derechos Culturales. Asamblea General de Naciones Unidas. Consejo de Derechos Humanos. Disponible en: http://documents-ddsny.un.org/doc/UNDOC/GEN/G16/017/00/PDF [Última consulta: 26/12/2020]

Bleijenbergh, I. (2018). Transformational change towards gender equality: An autobiographical reflection on resistance during participatory action research: The interdisciplinary journal of organization, theory and society. Organization, 25(1), 131-138. doi: http://dx.doi.org/10.1177/1350508417726547

Cabrero, F. (2006). El tercer mundo no existe. Diversidad cultural y desarrollo. Dossiers para entender el mundo. Barcelona: Intermón-Oxfam.

Camps, V. (1998). El siglo de las mujeres. Madrid: Cátedra.

Dent, E. B. and Galloway G. S. (1999) 'Challenging "Resistance to Change", Journal of Applied Behavioral Science 35(1): 25-41

Friedan, B. (2017). La mística de la feminidad. Madrid: Cátedra.

Gilligan, C. (1994). La moral y la teoría: psicología del desarrollo femenino. México D.F.: Fondo de cultura económica.

Herrero, Y.; Pascual, M. \& González Reyes, M. (2019). La vida en el centro. Voces y relatos ecofeministas. Madrid: Libros en Acción.

Hodder, I. (2010). "Cultural Heritage Rights: From Ownership and Descent to Justice and Well-being". Anthropological Quarterly. Vol 83 (4), Institute for Ethnographic Research (IFER) GEorge Washington University, pp. 861-882.

Jones, S. L., \& Van de Ven, A.,H. (2016). The changing nature of change resistance. The Journal of Applied Behavioral Science, 52(4), 482-506. doi: http://dx.doi. org/10.1177/0021886316671409 
Jordão, C., Carvalho, T., \& Diogo, S. (2020). Implementing gender equality plans through an action-research approach: Challenges and resistances. Kidmore End: Academic Conferences International Limited. doi: http://dx.doi.org/10.34190/ ERM.20.130

Lansu, M., Bleijenbergh, I., \& Benschop, Y. (2019). Seeing the system: Systemic gender knowledge to support transformational change towards gender equality in science. Gender, Work and Organization, 26(11), 1589-1605. doi: http://dx.doi. org/10.1111/gwao.12384

Lewin, K. (1946). Action Research and Minority Problems', Journal of Social Issues 1(2): 34-46

Martinell, A. (2015). “Cultura para el desarrollo y educación: ciudadanos globales”, EDHC, Quaderns Electrònics sobre el desenvolupament humà i la cooperació, 5, pp. 58-70.

Martínez-Usarralde, M. J. (2011): Sentipensar el Sur: cooperación al desarrollo y educación, Col·lecció La Nau Solidària, Valencia: Publicacions de la Universitat de València.

Mead, M. (2019). Cultura y Compromiso: Estudios sobre la ruptura generacional. Barcelona: Gedisa editorial.

Peredo, J. \& Haba-Osca, J. (2019). "Repensar la evolución humana en clase de Biología en $4^{\circ}$ de la ESO”. Educación multidisciplinar para la Igualdad de Género. Perspectivas traductológicas, ecoartísticas, socioeducativas y jurídicas. Valencia: Editorial Universitat Politècnica de València.

Sağlame, G. et al (2016) FESTA Deliverable WP7 Handbook on Resistance to gender Equality in Academia, FESTA. ISBN 978- 87-93152-13-7. Disponible en: http:// www.resge.eu

Unceta, K. (2013) "La universidad como ámbito para la promoción del desarrollo humano", en Ramírez-Blanco, M. J. (coord.) Actas del VI Congreso Universidad y Cooperación al desarrollo. Desarrollo humano y diversidad. Valencia, Universitat Politècnica de València.

UNESCO (2003). Convención para la salvaguarda del patrimonio cultural inmaterial. París. Disponible en: http://portal.unesco.org/es/ev.php-URL_ID=17716\&URL $\mathrm{DO}=\mathrm{DO}$ TOPIC\&URL_SECTION=201.html [Última consulta: 21/12/2020]

Valcárcel, A. (2014). Feminismo en el mundo global. Madrid: Cátedra.

Walker, M. (2006). Higher Education Pedagogies. Berkshire: The society for research into Higher Education and Open University Press.

Wollstonecraft, M. (2020). Vindicación de los derechos de la mujer. Madrid: Penguin clásicos. 



\title{
Capítulo 11 Moby Dick. El Mal Amor. Analogía entre una historia de violencia de género y el clásico de Herman Melville
}

\author{
Daniel M. Ambrona Carrasco \\ Colegio La Baronía San Antonio Abad de Gilet (Valencia)
}

\subsection{Introducción}

El 6 de octubre del año 2016 la Compañía de Danza Transfermove y la compañía de teatro Arden Producciones estrenaban la obra Moby Dick. El Mal Amor en la Sala Russafa de Valencia. Se trataba de una puesta en escena que utilizaba la novela de Herman Melville (1851) como punto de partida. La idea original fue de Toni Aparisi (premio MAX 2016 al Mejor Intérprete Masculino y a la Mejor Coreografía por Pinoxxio), quien también codirigía la obra junto a Chema Cardeña.

La idea se había gestado previamente, en el año 2015, en los talleres CulturArts que Aparisi impartía en la ESAD a profesionales de las artes escénicas de diferentes disciplinas para colaborar en su inserción laboral, con la colaboración de la también bailarina y coreógrafa Iris Pintos.

Aquella primera aproximación, estrenada en el Teatro Rialto en noviembre de 2015, consistía en una función de danza en la cual los participantes del taller habían bailado, construido e improvisado piezas inspiradas en la novela de Melville. Según declaraba Aparisi, la idea surgió al observar que "el capitán tiene una obsesión con la ballena, quiere hacerla suya, perseguirla e impedir que nadie que no sea él la mate. Y cuando consigue su objetivo no le importa morir" (La Vanguardia, 2016). Preparando el taller, Aparisi y Pintos trasladaron la relación entre el capitán Ahab y la ballena al código de una relación sentimental y rápidamente surgió la idea: "una historia de violencia de género encaja perfectamente con la obsesión del capitán por matar a un ser vivo. Esta obra trata sobre esa obsesión que desarrolla el ser humano en la violencia machista" (La Vanguardia, 2016). Y añadía: 
La obsesión que desarrolla el capitán Ahab por la ballena, la personaliza poniéndole nombre al animal, piensa que es solo suya, es mutilado por ella a causa de la agresión que él provoca, siente que la ballena es suya y convierte el matar a la ballena en el objetivo de su vida aunque cause su propia destrucción y la de todo el mundo que le rodea, que es exactamente lo que provoca un maltratador.

Para desarrollar esta idea, Aparisi contó en las fases previas a la creación con el asesoramiento de una psicóloga especializada en este tipo de violencia y delitos, Amàlia Alba, presidenta de la Federació d'Associacions de Dones Progressistes, y lo hizo con varios objetivos: en primer lugar, porque necesitaba la confirmación por parte de un especialista de que se podía establecer dicha analogía de forma razonable. En este sentido, la especialista secundó positivamente la alegoría de Aparisi y además, le aconsejó la lectura del libro Mi marido me pega lo normal, de Miguel Lorente Acosta (2003), toda una referencia dentro del análisis de la agresión a la mujer desde una perspectiva médica, legal y moral.

En segundo lugar, el coreógrafo, bailarín y director afirmaba la necesidad de documentación para el correcto desarrollo de la puesta en escena:

Hay ideas muy equivocadas sobre el amor, que aceptan el control o la obsesión como parte de un ideal romántico. Quería documentarme para poder reflejar en el espectáculo cuáles son las fases, cómo una relación que empieza siendo amorosa se convierte en violenta. (Valenciaplaza.com, 2016)

En tercer y último lugar, Aparisi quería "conocer cómo se sienten las mujeres que la han sufrido y ver mejor el paralelismo” (La Vanguardia, 2016)

Gracias a este asesoramiento, Aparisi y Pintos desarrollaron la analogía de forma evidente:

Ahab considera que el cachalote es suyo, del mismo modo que hay hombres que tratan a sus mujeres como una propiedad. Cuando los abandonan, es como si perdieran una parte de su cuerpo, de igual forma que el capitán se queda sin una extremidad. Es entonces cuando se deshumaniza, porque su leitmotiv pasa a ser acabar con la vida de la ballena. El sacrificio de sus marineros es una metáfora del daño que los maltratadores causan a sus hijos (Donat, 2017).

\subsection{Justificación y objetivos de la puesta en escena: sensibilización, denuncia, conciencia, testimonio y educación}

Ante la realidad de la violencia de género y la necesidad de sensibilización al respecto, Toni Aparisi llevó a cabo esta ambiciosa analogía, un elaborado paralelismo a partir de la obra de Melville para crear un alegato contra la violencia de género y con el objetivo de denunciar la falta de atención, comprensión y apoyo que muchas mujeres padecen en nuestro país frente a los daños físicos y psicológicos infligidos por los hombres, dar voz a las víctimas que los padecen, ser un altavoz para ellas y aportar, de este modo, "un grano de arena para que la sociedad tome conciencia" (La Vanguardia, 2016).

Al trasladar la idea al escenario, Aparisi temía que el mensaje pudiera perderse al ser transmitido únicamente a través de la danza, por lo que incorporó al proyecto al drama- 
turgo Chema Cardeña. Este escribió el texto de la obra, y juntos lograron un espectáculo de denuncia, en el que la trama de Melville tiene un papel vehicular.

Entre ambas historias, novela y obra de teatro, existe un verdadero equilibrio temático. Todo está muy equilibrado sobre el escenario, ya que Aparisi y Cardeña no pretendían que fuese un espectáculo de danza con texto. Por tanto, se plantearon los lenguajes presentes en el escenario: el lenguaje pictórico, el lenguaje musical, el lenguaje textual y el lenguaje corporal, integrando todos ellos en un único lenguaje común y tejiendo así un espectáculo multidisciplinar al estilo de la compañía Arden que codirige el propio Chema Cardeña, disciplinas con las que Sala Russafa suele contar en su programación, temporada tras temporada.

La denuncia y el objetivo de concienciar a nuestra sociedad sobre la problemática de la violencia de género y la violencia machista se vio completada en esta ocasión, representando la obra en el Palau de la Música de Valencia en una campaña preventiva para institutos. Tanto Aparisi como Cardeña coinciden en que es en la educación donde se debe realizar mayor hincapié para poder acabar con esta lacra enraizada en nuestra cultura. Por ello, se debe prevenir y sensibilizar a la población, muy especialmente a adolescentes, ya que muchos de ellos han vivido situaciones de este tipo de violencia en primera persona, además de que entre ellos se encuentran los futuros maltratadores. Nos encontramos ante una adolescencia que tiende a normalizar estos actos, desensibilizada, y donde el libre acceso a la pornografía y prostitución desde muy jóvenes son caldo de cultivo para las agresiones sexuales y la violencia machista en general.

"No ha habido función que no haya coincidido con un asesinato" (Donat, 2017), afirmaba alarmado Aparisi. Al analizar los datos, comprobamos que estos justifican que las compañías teatrales se encuentren en la necesidad de representar obras que denuncien la situación de la violencia de género y la violencia machista en España:

- En el año 2015, año en que se creó la obra, 62 mujeres murieron a manos de su pareja o expareja.

- Según la Delegación del Gobierno contra la Violencia de Género, entre los años 2003 y 2019 el número de víctimas mortales por este tipo de violencia en España a manos de sus parejas o exparejas fue de 1033 mujeres (Delegación de Gobierno contra la violencia de género, 2020).

- El número de mujeres víctimas de violencia de género aumentó un $2 \%$ en el año 2019, hasta 31.911 casos. La tasa de víctimas de violencia de género fue de 1,5 por cada 1.000 mujeres de 14 y más años. El número de víctimas de violencia doméstica creció un 3,6 \%. (INE, 2020)

- En los primeros 9 meses del año 2020 las víctimas mortales a causa de la violencia de género ascendían a 36, según el Ministerio de la Presidencia, Relaciones con las Cortes e Igualdad (EPDATA).

- Según Save the Children, desde el año 2013, en que se comenzara a contabilizar en España, los niños y niñas víctimas mortales a manos de sus padres o parejas de 
sus madres o en el caso de chicas jóvenes, por sus propias parejas, hasta octubre de 2020, el número de víctimas asciende a 52.

Qué duda cabe de que, con el objetivo de la sensibilización, el arte desempeña un papel muy relevante. Así lo aseguran también Cenizo et al. (2003) en su estudio:

\begin{abstract}
Una de las vías más útiles para llegar al entramado emocional de la persona, y desde ahí sensibilizar y lograr una cierta toma de conciencia de los patrones establecidos dentro de su propio sistema personal y social es el arte: la pintura como forma de expresión y de proyección de las emociones, la música liberadora o relajante, la danza como forma de dejar a nuestro cuerpo que se exprese en ese lenguaje tan vivencial y el teatro como forma de vivir una experiencia tan compleja y penetrante como la de ser el que da vida al propio protagonista de la historia. (pág. 256)
\end{abstract}

\title{
11.3. El compromiso social de Sala Russafa
}

El Centro Cultural Docente de Artes Escénicas Sala Russafa es un proyecto que la compañía de teatro Arden Producciones ponía en pie en el año 2011. Desde entonces, la sala posee un amplio historial de producciones comprometidas socialmente, compromiso desarrollado con gran éxito en los últimos años tanto por parte de la propia compañía Arden, como por parte de otras compañías invitadas que han tenido la posibilidad de presentar sus montajes en la sala valenciana.

Cada temporada, Sala Russafa presenta una parte de su programación que entronca con el activismo social, de modo que intenta organizar, albergar y compartir producciones y actos que pudieran tener que ver con lo solidario o con una acción social, bien denunciando o bien intentando concienciar al público de ciertas necesidades que tiene la sociedad y que el teatro, de alguna manera, como reflejo de la sociedad, tiene la misión de desarrollar, así como las artes tienen la misión de zarandear conciencias.

Arden y su director y cofundador, Chema Cardeña, han llevado a escena en los últimos años en la sala producciones que han seguido ese activismo social, con el objetivo de hacer reflexionar al espectador desde la ironía. Algunos ejemplos serían:

- Revolución (2013).

- "Trilogía Política", compuesta por tres obras:

- Alicia en Wonderland (2014).

- Buscando al Mago de Oz (Oh, Europa!) (2015).

- Viaje a Nuncajamás (2016).

La Trilogía fue todo un éxito y permitía al público apreciar cómo iba cambiando la problemática social más urgente en aquellos tres años.

- Yla Nave... Va? (2018).

- Shakespeare en Berlin (2018).

- La Invasión de los Bárbaros (2020). 
Por otro lado, en la sala también se han presentado en los últimos años diversas producciones y proyectos sociales junto a diferentes compañías. Algunos ejemplos serían:

- ¿Por qué duele cuando no hay dolor? (2014). Compañía Theatretk. Teatro inclusivo.

- Programa "Especial Refugiados" (2017), en torno a la crisis migratoria. Incluyó la representación de Los Invitados, de la compañía valenciana Colectivo Fracasadas y dirigida por Ximo Flores.

- En 2018 Sala Russafa dio eco al proyecto "DRAP", junto a la compañía Mou dansa y la ONG Setem Comunitat Valenciana. Propuesta escénica socialmente comprometida que denunciaba el consumo compulsivo, la explotación laboral y el impacto derivado de la industria textil sobre el medioambiente.

El último ejemplo que citaremos es el más actual y el que más relación temática pudiera tener con Moby Dick. El Mal Amor:

- Threesome (2020) Compañía Alarcón \& Cornelles. Desarrollaba una trama centrada en el contexto español para reclamar cambios legislativos que distingan la violación del abuso sexual.

\subsection{El compromiso del teatro español con la violencia de género en el siglo XXI}

Moby Dick. El Mal Amor y Threesome no han sido los únicos montajes que han abordado esta temática en nuestro país en las primeras décadas del siglo XXI. Tal y como afirma Jódar Peinado (2018):

La violencia machista se ha convertido en una de las preocupaciones fundamentales del feminismo, por lo que se trata de un tema que las dramaturgas españolas van a analizar con una clara voluntad de denuncia y concienciación social (...) encontramos tanto violencia de género en la pareja como abusos a niñas o mutilación genital. El tratamiento de este tema comienza por la abierta exposición de la violencia, para terminar con un análisis de las causas, apuntando al machismo social. (pág. 624).

Sin embargo y afortunadamente, no solo encontramos textos de dramaturgas, ya que cada vez son más los dramaturgos que tratan esta problemática. En la segunda década del siglo XXI, un elevado número de compañías se ha visto en la necesidad de reflejar la problemática de la violencia de género y violencia machista en sus programaciones, así como la discriminación sexual o la imposición de los roles de género. Algunos ejemplos fueron los siguientes, aunque hubo muchos más, especialmente de corte local:

- No Solo Duelen los Golpes (2016). Monólogo teatral de Pamela Palenciano en el cual la actriz contaba su experiencia de pareja junto a un maltratador durante 6 años de relación en la que sufrió abusos, sometimiento y violencia machista. 
- Cuidado con el Perro (2018), escrita por Eva Redondo, en la sala la Cuarta Pared de Madrid, que denuncia la violencia contra las mujeres y niñas en diferentes partes del mundo, como Bangkok o Madrid.

- Jauría (2019), escalofriante dramaturgia de Miguel del Arco y el Teatro Pavón Kamikaze de Madrid, a partir del juicio celebrado a "La Manada" dentro del caso de violación grupal en Pamplona el 7 de julio de 2016, con texto de Jordi Casanovas. Esta producción recibió el XVI Premio Cultura Contra la Violencia de Género 2019 otorgado por el Ministerio de Igualdad, entre otros muchos premios.

- Macho Man (2019), de Àlex Rigola y Teatros del Canal. Este montaje de instalaciones, sin actores, mostraba testimonios reales de mujeres maltratadas. Estaba principalmente destinada a sensibilizar a adolescentes por su alto valor educativo.

- Las peladas (Soledad de ausencia) (2019). Thriller psicológico de David RoldánOru. Un homenaje a las mujeres que sufrieron humillaciones y torturas durante y tras la Guerra Civil por el hecho de ser madres, esposas e hijas de rojos y, en definitiva, por ser mujeres y ser consideradas el sexo débil.

\subsection{Jornada Educativa del $25 / 11 / 2015$}

La puesta en escena de Moby Dick. El Mal Amor no fue la única aportación que Toni Aparisi y Chema Cardeña llevaron a cabo, ya que ambos quisieron ir más allá y organizaron una jornada el 25 de noviembre de 2015, Día Internacional para la Eliminación de la Violencia contra la Mujer, en la que reunieron a algunas de las principales voces que se enfrentan a diario a la violencia machista y en la que seis destacadas ponentes de distintos ámbitos participaron analizando la situación de este tipo de violencia desde distintas perspectivas. Una de ellas fue Isabel Lozano, regidora de Igualdad y Políticas Inclusivas del Ayuntamiento de Valencia, quien recordó el escalofriante dato de que "solo en la última década 20 mujeres han fallecido en la capital valenciana", y destacó "la necesidad de una concienciación social en la que las instituciones tienen parte activa" (Valenciaplaza.com, 2016)

Isabel García, diputada de Juventud, Deportes e Igualdad de la Diputación de Valencia, remarcó "la necesidad de implantar planes de igualdad en todos los municipios para trabajar no solo en las grandes capitales, también en pequeñas poblaciones" (Valenciaplaza. com, 2016), y zonas rurales.

Otra de las invitadas fue Pilar Gil, directora de la Oficina de Atención a la Víctima del Delito, quien comentó sobre la positiva evolución del funcionamiento que tiene este organismo desde su creación:

Está costando mucho, pero las instituciones se están concienciando, se ha mejorado la coordinación entre ellas y la colaboración. Pero nos queda un camino por hacer porque hay que luchar contra centenares de años de cultura patriarcal, hay que cambiar muchas cosas que están en la raíz del problema" (Valenciaplaza.com, 2016). 
Rosa Guiralt, fiscal delegada de Violencia de Género, fue otra de las participantes y cuestionó el sistema asistencial a las víctimas, que les proporciona casas de acogida y viviendas sociales, alterando sus vidas por completo y alejándolas de sus familiares y amigos, mientras sus agresores se quedan en su mismo entorno sin alterar sus vidas, manteniendo sus relaciones sociales y su libertad.

También intervino Macu Gimeno, coordinadora del área Dona de la Intersindical Valenciana. Una de las palabras más pronunciadas, tanto en su intervención como en el resto de la mesa redonda, fue la palabra "igualdad" y la necesidad de la misma. Gimeno señalaba al respecto que "la igualdad no está en la agenda de los políticos, pero tampoco en la de las personas, nunca aparece entre los principales temas de preocupación de los españoles" ${ }^{\prime 3}$.

Por su parte, Amàlia Alba destacó la capacidad del montaje de Aparisi y Cardeña para contribuir a esa concienciación social necesaria afirmando:

Es una pieza muy trabajada, que ha recogido opiniones y voces distintas y que ha sabido trasladar los distintos elementos que entran en juego en la violencia machista a través de un lenguaje novedoso, que puede interesar a los jóvenes y a mucha gente ${ }^{32}$.

Además de estas magníficas aportaciones, la Plaza del Ayuntamiento sirvió de escenario para una feria muy particular en la que se reunieron las principales asociaciones sociales que trabajan a favor de la mujer y contra la violencia de género y machista. En la misma también tuvieron lugar las artes plásticas y artes escénicas con intervenciones artísticas con el importante objetivo de dar visibilidad a esta problemática.

\subsection{Análisis del texto y puesta en escena de Moby Dick. El Mal Amor}

En lo que al espectáculo en sí se refiere, aprovechando e interrelacionando las herramientas que ofrecen las diferentes expresiones artísticas que se reúnen sobre las tablas, este espectáculo iba narrando sin tapujos ni visiones poéticas las fases que se suceden en este "mal amor" que suele conducir a un trágico desenlace, similar al del clásico de Melville.

El espectáculo reunía las tres disciplinas que Sala Russafa presenta cada temporada: los ya mencionados teatro y danza por parte de Chema Cardeña y Toni Aparisi, a los que se sumaban la música en directo y original a cargo de Jesús Serrano al piano y la escenografía y mural del artista plástico Claudio Zirotti. Al respecto, Aparisi defendía la aportación de "una propuesta interdisciplinar porque todo suma, el teatro, la danza, la música y el arte. La cultura es una herramienta fundamental para la difusión, pero también para la concienciación social que en este tema es absolutamente necesario". (Valenciaplaza. com. 2016).

\footnotetext{
${ }^{31}$ En Valenciaplaza.com. 2016

${ }^{32}$ En Valenciaplaza.com. 2016
} 
Con una duración de 50 minutos, los personajes que aparecían en escena eran dos: el capitán Ahab, interpretado por Chema Cardeña y Blanche, trasunto humano de la ballena, interpretada por la actriz Iria Márquez. Ambos daban vida a una serie de crudos y realistas monólogos que reflejaban la evolución de esta relación de maltrato, desarrollando el proceso de destrucción psicológico y físico que padecen las mujeres que lo sufren.

Aparisi decidió llamar Blanche al personaje femenino por el color de la ballena, y también en la novela de Melville se refieren a ella de esta forma en una ocasión, en el capítulo XCI, "The Pequod meets the Rose Bud". Cuando el barco capitaneado por Ahab se encuentra con el barco francés Rose Bud, Stubb les preguntaba si habían visto a la ballena, a lo que el primer oficial del barco francés le respondía refiriéndose a ella como Blanche en su idioma:

\section{'The White Whale -- a Sperm Whale -- Moby Dick, have ye seen him?' \\ 'Never heard of such a whale. Cachalot Blanche! White Whale -- no.' (pág. 402)}

Los personajes también eran interpretados por dos bailarines: Toni Aparisi e Iris Pintos, que actuaban como una especie de alter ego de Ahab y Blanche. Convendría aportar que aparecían solo dos personajes, puesto que Aparisi tenía un objetivo claro: "la intención al reducir los personajes al mínimo es personalizar. Así el espectador no ve a los dos protagonistas cómo números, sino como gente real, que puedes tener a tu lado (Donat, 2017).

$\mathrm{Al}$ analizar la puesta en escena observamos que, al contrario de obras de esta temática como ;Arriba la Paqui! de Carmen Resino (2007), por ejemplo, no se representaba violencia física sobre el escenario, algo que, por otra parte, habría sido lo más sencillo en la búsqueda del impacto y el morbo. En cambio, tanto Aparisi como Cardeña prefirieron no escenificar golpes físicos: "creo que la música, el texto y la danza son lenguajes que harán entender la violencia de género al público" (La Vanguardia, 2016). De este modo, se transmitía al espectador las emociones físicamente, a partir del movimiento, los gestos, energías y miradas. El diario La Vanguardia aseguraba al respecto: "sin un solo golpe, pero sin faltar al realismo y con un lenguaje escénico capaz de comunicarse por la vía física, verbal y emocional con el espectador" (2016).

En cuanto al texto, para cuyo análisis citaremos el guion de texto del propio Cardeña, observamos que se intercalan extractos originales de la novela, aunque muy escasos, con pasajes propios de Cardeña, donde Ahab describía cómo se enamoraba, de qué manera iba atrapando a Blanche en sus redes, su ira cuando esta quiere escapar de ellas y cómo tramaba el asesinato final. También observamos el proceso de sufrimiento de Blanche desde una primera fase de enamoramiento hasta su asesinato.

La obra da comienzo con el piano de Jesús Serrano, y un narrador introducía la historia y objetivos de Ahab:

Aunque consumido por el ardiente fuego de su propósito, Ahab tenía siempre en la mira, en todos sus pensamientos y acciones, la captura final de Moby Dick, parecía preparado para sacrificar todos los intereses mortales a esa única posesión. (pág. 1) 
Este fragmento, aunque adaptado, es uno de los escasos fragmentos de texto de la novela de Melville, el cual pertenece al capítulo XLVI "Surmises".

Después, el primer monólogo, titulado "Bitácora 1", pertenece a Ahab, cuyos monólogos (a excepción del último) se titulan "Bitácora", como si del diario de a bordo del capitán se tratase.

En este primer monólogo, Ahab relata cuándo ha avistado a Blanche por primera vez: "hoy la vi por primera vez. Caminaba rumbo sudeste" (pág. 1); y cómo se enamora de ella por ser especial y diferente al resto: "nunca había visto una mujer así. Una mujer que irradie tanta luz a cada paso que da" (pág. 1); y establece comparaciones entre la joven y la ballena, ya que no parece caminar sino "flotar como deslizándose sobre el azulado mar" (pág. 1). Posteriormente, observamos referencias al mar: "su mirada era la de alguien que ve el mar por primera vez" (pág. 1), "sin perder de vista sus ojos, que como las sirenas a Ulises, parecían arrastrarme" y "sin duda escapó de lo más profundo de los océanos para convertirse en ma belle blanche” (pág. 1). Estas referencias marinas se repetirán a lo largo de toda la obra.

Tras este primer monólogo, asistimos al primer encuentro entre ambos, en el que Ahab aborda a Blanche y establece comunicación con ella:

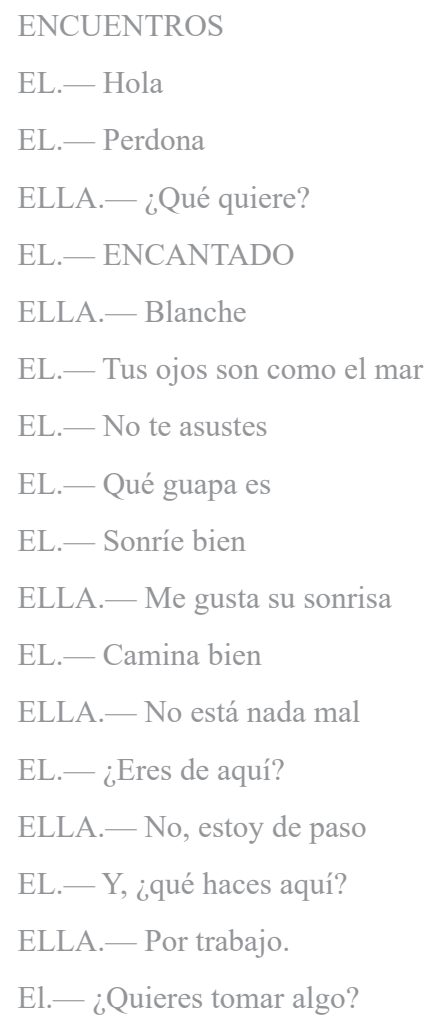




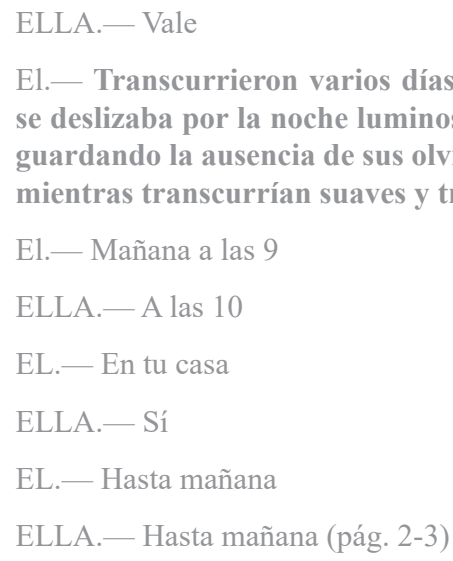

En todo el texto tan solo hay dos diálogos entre ambos. Este era el primero, breve y rápido, aportando ritmo a la obra. En él se intercala un breve fragmento de texto de la novela de Melville, aunque adaptado y recortado por Cardeña. Lo narra Ahab muy cerca del oído a Blanche con la intención de seducirla. Este aparece en la obra original al comienzo del capítulo XXIX "Enter Ahab; to him, Stubb".

Tras ese primer encuentro, tiene lugar "Bitácora 2", monólogo en el que Ahab se muestra satisfecho por la conquista, y compara a Blanche con sus conquistas anteriores, todas en peor consideración: "Sí, esta vez sí. Muchas leguas en tu busca. Muchas otras en tu lugar, todas rumbo noreste y ella siempre rumbo al sur. Ahora todas parecen vacías, pequeñas, insignificantes. Ahora sí. Te he encontrado. Te he dado alcance". (pág. 3)

Incluso llega a considerar a Blanche "la joya del océano" o "la perla de los siete mares", continuando con las referencias marinas.

De este monólogo, llama poderosamente la atención ese sentimiento de posesión que rápidamente desarrolla Ahab sobre Blanche y que expresa en diferentes ocasiones en el mismo: "eres mía. Mía para siempre y para todo"; "tu primer y único pensamiento. Tus acciones, tus sonrisas, tus lágrimas me pertenecen para siempre" y "eres mía Blanche". (pág. 3)

Ni siquiera tienen una relación de pareja todavía y él ya la considera de su propiedad. Todo lo que a ella se refiera, él ya lo considera suyo, y con su afirmación "no permitiré que nadie se apropie de lo que es mío" (pág. 3) demuestra que está dispuesto a todo para que así sea.

El siguiente monólogo, "Amor”, lo pronuncia Blanche. Cardeña da voz al personaje femenino tras dos monólogos del personaje masculino, algo que no resulta casual. Él tiene voz primero y decide sobre Blanche antes que podamos conocer sus reflexiones.

"Le amo. Y él me ama. Soy una mujer muy afortunada". (pág. 3-4)

${ }^{33}$ En negrita, el texto del original de Melville. 
Al principio de este primer monólogo, Blanche muestra sus sentimientos. Se siente afortunada por haber conocido al hombre de sus sueños, inmersa en una primera fase de enamoramiento. "El hombre con que todas soñamos alguna vez, y que creemos que nunca va a llegar". (pág. 3-4)

Aunque lo que ella destaca como un halago, los espectadores lo vemos como un exceso de control por parte de Ahab: "Sus ojos siempre están pendientes de los míos. Me observa a cada movimiento. Se interesa por todo cuanto hago. Dónde voy, con quién voy, qué voy a hacer". "Le importa cómo llevo mi cabello, qué ropa me pongo, qué como o qué bebo. Toda yo le intereso". (pág. 3-4). Ahab controla todos los aspectos de su persona.

También afirma que Ahab persiste en darle instrucciones para que todo salga bien. Mientras, nosotros como espectadores observamos que es parte del control encubierto que pretende ejercer sobre ella. Quiere que las cosas se hagan a su manera.

Posteriormente, Blanche afirma:

Mis amigas dicen que lo encuentran demasiado controlador, y yo les digo que no saben lo que dicen. Que si estuvieran en mi piel, bendecirían cada hora que pasaran con él. A mi familia le molesta tanta observación por su parte. Él se ríe de ellos, y dice que no me merecen. Que debo cambiar de amigas, o algo mucho mejor. Que solo él es mi amigo, mi familia, mi hogar. (pág. 3-4)

Sus amigas y familiares, al estar fuera de esta relación, comparten la visión del espectador y consideran un exceso de control por parte de Ahab, por eso él se ofrece como su única opción. Los maltratadores psicológicos tienden a aislar a las víctimas y alejarlas de su entorno más cercano y sus relaciones establecidas, ejerciendo así una relación de poder y supremacía sobre ellas. Como comprobamos, la víctima no es capaz de verlo, inmersa en la fase de enamoramiento.

Asistimos, claramente, al comienzo de la denominada "escalada de violencia". Esta, del mismo modo que observamos en la obra:

comienza con conductas de abuso psicológico bajo la apariencia y expresión, por parte del agresor, de actitudes de cuidado y protección, difíciles de percibir por su apariencia amorosa, pero que van reduciendo la seguridad y la confianza de la mujer en sí misma y su capacidad de reacción. Se trata de conductas restrictivas y controladoras, que van minando su autonomía, a la vez que la sitúan en condiciones de dependencia y aislamiento. Un ejemplo son los celos, la vigilancia, la censura sobre la ropa, amistades o actividades, el control de los horarios, las salidas fuera de la casa, etc. Habitualmente estas conductas, que suelen ser la antesala del maltrato físico, no se perciben por parte de las mujeres como agresivas, sino como manifestaciones del carácter de la pareja o de rasgos masculinos por excelencia (rol dominante y protector a un tiempo), que se han interiorizado como normales a través de los procesos de socialización en la familia, la escuela o la calle, por lo que su importancia suele ser minimizada y son admitidas tácitamente, lo que genera a las mujeres situaciones de indefensión aprendida y vulnerabilidad. (Guía del Instituto Canario de la Mujer, p. 28).

A continuación asistimos al segundo y último diálogo entre ambos. En este diálogo, observamos que la relación ha evolucionado negativamente y cómo Blanche expresa 
voluntades, actividades que quiere hacer pero él se las niega todas, anulando su voluntad y anulando así a la persona por completo.

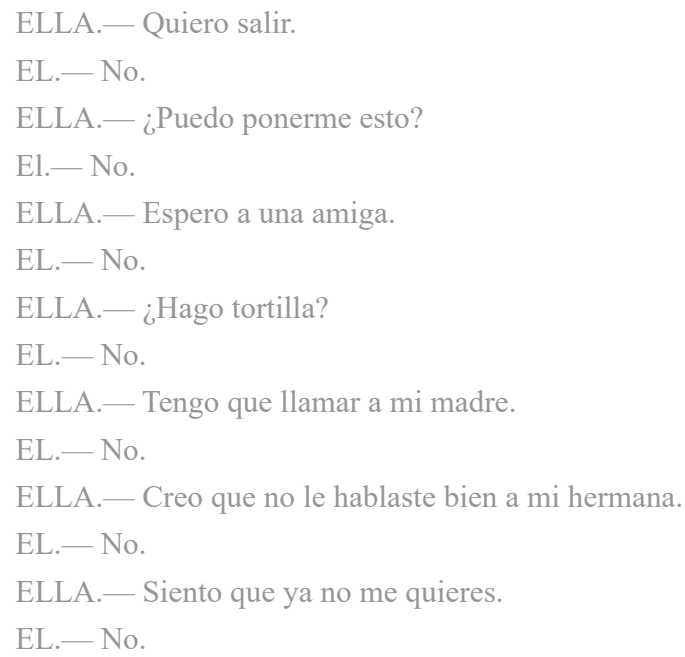

ELLA.- Bien, pues, quiero, puedo, espero, hago, tengo, creo, siento. Quiero, puedo, espero, hago, tengo, creo, siento. Quiero, puedo, espero, hago, tengo, creo, siento. Quiero, puedo, espero, hago, tengo, creo, siento. Quiero, puedo, espero, hago, tengo, creo, siento. Quiero, puedo, espero, hago, tengo, creo, siento. Quiero, puedo, espero, hago, tengo, creo, siento. Quiero, puedo, espero, hago, tengo, creo, siento. (págs. 4-5)

Tras tanta negativa, ella le expresa su deseo de querer, poder, esperar, hacer, tener, creer y sentir, en definitiva, SER. En esta intervención repitiendo una y otra vez sus anhelos, el tono va in crescendo hasta que vuelve a bajar, siendo finalmente sometida de nuevo.

Según Madina (2005), esta anulación respondería a la violencia denominada "instrumental", desarrollada por el tipo de maltratador considerado "hombre inmaduro", en la que "claramente hay una intención de anulación de la persona, de acabar con ella, a través de machacarla psicológicamente y de amenazarla e incluso agredirla físicamente".

En el siguiente monólogo, titulado "Dudas", las dudas alcanzan a Blanche, quien reflexiona y muestra su deseo de ser, como persona individual, independiente, de poder tomar sus propias decisiones, de sentirse ella misma. Comienza, por tanto, a darse cuenta de que está anulada y que ha perdido toda su vida social y familiar:

Estoy confusa. No alcanzo a entender tanta negativa. Puedo entender que no todo sea de su agrado pero esto... Esto no me parece normal. No hay nada malo en salir a la calle sin él, tal vez sean celos, y eso me halaga pero puede ser asfixiante.

Yo tengo que elegir mi propia ropa, sé que solo tiene ojos para mí, pero yo no solo me visto para él. También quiero sentirme yo misma. (pág. 5)

Necesito ver a más gente. Hace meses que sólo le veo a él. Quiero comunicarme con mis amigos y mi familia. No puedo seguir en el mismo lugar por siempre. 


\begin{abstract}
Yo antes tomaba mis propias decisiones, ahora debe consensuarlas siempre y eso es agotador. La comida, la ropa, las llamadas, las salidas... todo.

Creo que me está devorando. Que vivo con un vampiro agarrado a mi cuello. Que ya no soy yo. Esto no puede ser amor. Esta cárcel cada vez es más estrecha. Y debo reconocer que me he equivocado. ¿Cómo ha podido caer así en su red? (pág. 5)
\end{abstract}

Al final de cada uno de estos párrafos, Blanche cae al suelo y se vuelve a levantar, como si cada una de estas reflexiones fuese un mazazo para ella, un duro golpe a su persona.

Moral Jiménez et al. (2008) afirman que este tipo de víctimas son dependientes emocionales que, como Blanche, "suelen soportar desprecios y humillaciones, no reciben verdadero afecto, (...) observan cómo sus gustos y aficiones son relegados a un segundo plano, renuncian a su orgullo o a sus ideales". (pág. 161)

El final de este monólogo resulta muy interesante: “¿Cómo ha podido pasarme esto a mí? ¿Por amor? No, esto no puede ser amor. Esto es otra cosa que yo no creí nunca poder vivir" (pág'. 5), reflexiona muy acertadamente Blanche, y por fin, reconoce su error y que debe poner fin a la relación y escapar sin mirar atrás, aunque cuando estas víctimas alcanzan ese momento de lucidez puede que sea demasiado tarde para ellas.

Además, se pregunta cómo ha podido caer en sus redes, igual que la ballena cae en las redes de un pescador. Todos pensamos que algo así no nos puede suceder y que estamos a salvo. Sin embargo, cualquiera puede acabar siendo víctima de maltrato físico o psicológico en algún momento por parte de su pareja. Por tanto, Cardeña está advirtiendo a los espectadores de que hoy es Blanche pero mañana puede ser cualquiera.

En el siguiente monólogo, "Bitácora 3", se nos presenta la reacción de Ahab ante las dudas y el intento de huida por parte de Blanche y se nos muestra en escena a un asustado y furioso capitán.

En sus palabras: "me desespera no saber qué le dicen. Me aterra pensar que otras voces puedan seducirla" (pág. 5), observamos cómo el maltratador sufre cuando algo se escapa a su control y le llega el miedo, miedo a perderla.

Este monólogo se representa en escena acompañado de danza, ambos danzan juntos y él se interpone ante ella ante cada intento de avanzar por su parte. La música es perturbadora, acorde con la furia de sus palabras y su tono. En cambio, cuando él sale del escenario y danza ella a solas, la música vuelve a ser más pausada, tranquila y relajada.

En el siguiente monólogo, titulado "Reconocimiento", Blanche aparece de rodillas, llorando, cabizbaja, mientras actor y bailarín se suceden ante ella en lo que sugiere ser una metáfora del día a día y su llegada a casa. Al llegar, ella les calza y descalza los zapatos mientras recita sus palabras, y los gestos de ambos hacia ella se alternan entre la indiferencia y la agresividad.

Asistimos en este punto al sometimiento total de Blanche. Tras volver a su relación, se autoinculpa de no ser lo suficientemente buena para él, por no ser lo que él quiere e incluso acepta su falta de libertad y solo destaca cualidades negativas de su propia persona. 
Yo intento ser como tú quieres, pero no es fácil. Tal vez sea mi torpeza. Mi incapacidad para ver las cosas como tú las ves. Creo que he estado muy confundida. Que todo cuanto me enseñaron estaba equivocado. (...) Y puede que eso me conduzca a cometer errores.

Sé que hablo demasiado, que soy bastante torpe a la hora de hacer determinadas cosas. Que soy insegura, indecisa, que no conozco en verdad el mundo y que todo en lo que yo creía, eran cosas pueriles y a veces ridículas.

Sé que me estoy haciendo más fuerte junto a ti. Y que tus decisiones son acertadas. Yo no sé distinguir muchas veces qué está bien y qué está mal. Que a veces te pongo muy nervioso con mis acciones. No hago las cosas como deben ser, pero quiero que sepas que me esfuerzo. (págs. 6-7)

Este sentimiento de fracaso, unido a la inseguridad, baja autoestima tras haber sido anulada y sentirse responsable de las agresiones de las que ha sido víctima son varios de los principales factores que inciden en que la mujer regrese con su pareja agresor tras haber logrado romper la relación y seguir permitiendo el maltrato.

El aumento progresivo de la violencia, hasta llegar a las agresiones físicas e incluso a la muerte, puede extenderse a lo largo de un prolongado periodo de tiempo, durante el cual se incrementa la pérdida de referencias, autoestima, seguridad personal, de manera que es difícil para la mujer víctima percibir y entender el significado y la trascendencia del proceso en el que está inmersa, así como el riesgo que corre. (Guía del Instituto Canario de la Mujer, pág. 28)

También observamos en sus palabras la idea del "amor romántico" en que estas víctimas refuerzan su actitud de sumisión con gran carga de sacrificio, altruismo y abnegación: "Que una pareja exige sacrificio, entrega, comprensión... perdón”. (pág. 6)

Tras este monólogo ambos bailarines danzan de forma cariñosa al principio pero poco a poco Ahab va interpretando gestos agresivos hacia ella hasta que la acaba agarrando de los cabellos, mientras Blanche se nos muestra cual títere en sus manos. Esta danza se repite en bucle, en lo que podría sugerir al considerado como "ciclo de violencia", una de las teorías expuestas por la psicóloga americana Lenore Walker en 1979 y una de las teorías más aceptadas y difundidas sobre dinámicas internas en las relaciones violentas.

Este ciclo refleja el modo en que agresor y víctima se comportan dentro de cada una de las etapas de proceso de violencia, planteando la existencia de tres fases (en ocasiones se consideran cuatro) que pueden variar en el tiempo e intensidad pero que se suelen repetir: la fase de tensión o acumulación, la fase de agresión o tensión violenta, en la que estalla la violencia y, por último, la fase de calma o remisión, también conocida como de arrepentimiento, en la que se puede llegar a dar un interludio amoroso. En esta fase, las agresiones llegan a desaparecer y el agresor se suele mostrar arrepentido de sus actos, seduciendo a la víctima de nuevo con promesas de cambio. Esta fase también es conocida como "luna de miel", puesto que en ella ambos se muestran cariñosos y amables, emulando la vuelta al principio de la relación de afectividad. Sin embargo, esta fase da paso a una nueva fase de tensión, y en cada fase de tensión y agresión la intensidad es cada vez mayor. 
"Bitácora IV" es la última Bitácora de Ahab en la obra, aunque no su última intervención. En esta ocasión, el personaje aparece furioso entre sombras. El ciclo de violencia se repite y la intensidad ha crecido:

¡Maldita seas zorra del demonio! ¡Puta desagradecida! ¿Cómo has podido hacerme esto? Estúpida, Inútil, necia, torpe”. (pág. 7)

Blanche se ha escapado. Ha huido de mí. No es capaz de entender que sólo junto a mí está segura. Que solo yo puedo darle lo que necesita. Que todo cuanto hago es por su bien. Que desde el momento en que cayó en mi red soy su guía, su padre, su dueño, su amo. Que sin mí está perdida. Se ha ido. Y su ausencia es dolorosa. Es como la amputación de un miembro cercenado por una bestia despiadada. Y Duele. Y falta. Pero sobre todo duele. ¡Duele, duele, duele!

Mi propio cuerpo se ha rebelado contra mí. Un solo miembro ha provocado, esta sedición, este motín, esta traición. Has desobedecido el orden natural de las cosas. Pero tú fuiste hecha a partir de mí. No puedes salir de mí. No hay vida fuera de mí. (pág. 7)

En este monólogo, observamos que Ahab se refiere a Blanche con graves descalificativos, señal de pérdida total de respeto. También una referencia al clásico de Melville: "la amputación de un miembro cercenado por una bestia despiadada", como la pierna que pierde Ahab tras el ataque de Moby Dick. Aunque lo más llamativo y grave de esta bitácora son sus últimas palabras: "no hay vida sin mí", una grave advertencia y declaración de intenciones de Ahab.

La última intervención de Blanche fue titulada "Síndrome de Estocolmo", y en ella observábamos aceptación y resignación por su parte. No puede escapar. Esta actitud entronca claramente con la Teoría de la Indefensión Aprendida de Seligman, según la cual el continuo maltrato provocaría la percepción cognitiva a la víctima de que es incapaz de resolver la situación y, por tanto, le llevaría a aceptarla:

Cuando me alejo, me siento libre, ligera... pero al instante empiezan las dudas. Oigo su voz
y no quiero escucharla, pero me he acostumbrado a su sonido. A sus palabras. No sé ya si
son suyas o mías. No soy dueña de mis palabras, o tal vez él no es nadie sin las mías. Pero
siento el extraño vacío en mi seno. No, no es un vacío, es un dolor, un profundo dolor seco
que me atraviesa. Mis pies se paralizan, yo quiero andar, pero no puedo. El miedo es quien
rige mis actos. Una larga cola de escamas envuelve mis piernas y permanezco inmóvil. No
soy yo. Yo ya no soy yo. Espero el arpón frío e hiriente que atraviesa mi piel. Me ha vuelto
a cazar. Otra vez quiero alejarme, escapar. Pero la red es grande, gigante, enorme y yo de-
masiado pequeña, diminuta, insignificante y no tengo un saliente donde asirme y escapar.
Y cuando por fin me alejo, siento que quiero volver. Le echo de menos. Le veo entonces
a él, pequeño e insignificante, casi perdido y necesito estar con él. No puedo entenderlo,
pero creo que no hay otra explicación. Le amo. Esto que siento debe ser el amor, y el amor
duele. (págs.7-8)

Entre referencias marinas, Blanche danza mientras Ahab le interrumpe y le va diciendo: "Blanche, no hay vida sin mí / Blanche, no hay vida fuera de mí".

Sus "yo ya no soy yo" resuenan en los corazones de los espectadores de forma desoladora. Ella ya solo espera la muerte como la ballena espera el arpón que atraviesa su piel. 
No logra escapar, pero cuando lo consigue, como el secuestrado siente el síndrome de Estocolmo, siente que quiere volver con él. Se establece una relación de dependencia entre víctima y agresor y por ello, fruto de su confusión, alcanza una conclusión muy desacertada: "el amor duele".

Finalmente, Ahab, furioso, exclama:

\section{¿Por qué? ¿Qué te he hecho? ¡Quédate conmigo, no me hagas esto! \\ Te necesito, me necesitas. Eres mía. ¡No puedes escapar! ¡Eres de mi propiedad! ¡No te lo voy a consentir! \\ Perdóname, jte quiero! (pág. 8)}

Ahab le repetía las palabras que le recitaba al principio al seducirla, pero esta vez de una forma airada y con agresividad, agarrándola por el brazo sin dejarla marchar.

Y transcurrieron varios días y dejábamos a popa todos los icebergs. El Pequod se deslizaba por la noche luminosa de Quito. Interiormente se deslizaba hacia al alma, sobre todo cuando transcurrían tranquilas y suaves las olas del ocaso. (pág. 8)

De este modo llegamos a la escena final. Danzando, bailarín y actor rodean el cuello de Blanche con una soga roja como la sangre mientras ella intenta escapar, pero entre ambos la sujetan y estiran, poco a poco acercándola hacia ellos, en una analogía con la caza y muerte de la ballena, y Blanche finalmente caía al suelo inmóvil. Muerta. Ellos, dando vueltas a su alrededor recitaban:

Hacia vos navego, ballena conquistable que todo lo destruye. Por fin lidio con vos. Desde el corazón del infierno os escupo mi odio, os hiero, y por odio os envío mi último aliento. Ahora, ahora se ve cumplido mi propósito. Así os entrego la lanza, mi muerte solidaria para una vida solidaria. Ahora descubro que mi mayor grandeza fue mi mayor dolor. (pág. 8)

Se trata de un fragmento adaptado de la original de Melville de la última intervención de Ahab en la novela poco antes de morir intentando acabar con Moby Dick. Tras estas palabras, Ahab se suicida en escena. Frente a frente, Ahab y su alter ego, bailarín y actor, se acaban atravesando con una gran lanza el uno al otro.

Finalmente, la última intervención era para el pianista Jesús Serrano, quien avanzaba hasta ellos y decía: "Llamadme Ismael" (pág. 9). De esta forma da comienzo la novela de Melville y de esta forma acaba la obra de Aparisi y Cardeña, sugiriendo que el ciclo vuelve comenzar y que la música también cuenta la historia junto a ellos.

\subsection{Conclusiones}

Como hemos comprobado, recurrir a la violencia de género y violencia machista comienza a resultar frecuente en el teatro contemporáneo, señal de que dentro del compromiso social que desarrollan las artes escénicas, es un hecho necesario. Ante esta necesidad, Aparisi y Cardeña desarrollaron su proyecto multidisciplinar de danza, teatro, música y artes plásticas Moby Dick. El Mal Amor. 
En esta obra se desarrollan las fases de escalada de violencia y ciclos de violencia de forma muy acertada y con el objetivo de rasgar las conciencias de los espectadores, que no pueden permanecer ajenos a lo que ocurre sobre las tablas y, mucho menos, a lo que ocurre cada día en nuestro país.

Concluimos que estamos ante una obra necesaria en los escenarios valencianos y españoles. Es una producción necesaria por su alto valor escénico y artístico pero, ante todo, necesaria por su valor educativo, su mensaje de denuncia y su intención de advertir y concienciar a los espectadores sobre esta lacra presente en nuestra sociedad como es la violencia de género y la violencia machista.

\subsection{Referencias bibliográficas}

Cardeña, C. (Director). (2016). Moby Dick. El Mal Amor. DVD. Arden Producciones.

Cardeña, C. (Director). (2016). Moby Dick. El Mal Amor. Guión de Texto Teatral. Arden Producciones.

Cenizo Rodríguez, M., del Moral Arroyo, G. \& Varo Baena, R. (2011). El teatro como medio de sensibilización contra la violencia de género en la adolescencia. (Estudio exploratorio sobre el uso de la obra de teatro Ante el espejo como herramienta de prevención y sensibilización). Stichomythia 11 (12), 255-267. ISSN: 1579-7368

Delegación de Gobierno contra la violencia de género. https://violenciagenero.igualdad. gob.es/violenciaEnCifras/victimasMortales/fichaMujeres/home.htm

Donat, Begoña. Danza y teatro sensibilizan a una sociedad anestesiada frente a la violencia de género. 19-4-2017. https://alicanteplaza.es/Danzayteatrosensibilizanaunasociedadanestesiadafrentealaviolenciadegnero2

Europa Press Data. Violencia de género - datos y estadísticas. Octubre 2020. https:// www.epdata.es/datos/violencia-genero-estadisticas-ultima-victima/109/espa$\underline{\text { na/106 }}$

Guía para la Atención a Mujeres Víctimas de Violencia de Género Instituto Canario de la Mujer. www.educacionyfp.gob.es/va/dam/jcr:80e16748-7d58-4201-a262533ea09755fe/guia_atencion victimas violencia cambiada-21042008.pdf

Instituto Nacional de Estadística. Estadística de violencia doméstica y violencia de género. Año 2019. www.ine.es/dyngs/INEbase/es/operacion.htm?c=Estadistica_C $\underline{\mathrm{ccid}}=1254736176866 \& \mathrm{menu}=\mathrm{ultiDatos} \& \mathrm{id} \mathrm{p}=1254735573206 \#: \sim:$ text $=\mathrm{El} \% \overline{20}$ n\%C3\%BAmero $\% 20 \mathrm{de} \% 20$ mujeres $\% 20 \mathrm{v} \% \mathrm{C} 3 \%$ ADctimas, creci $\% \mathrm{C} 3 \% \mathrm{~B} 3 \% 20$ un $\% 203 \% 2 \mathrm{C} 6 \% 25$

Jódar Peinado, M. del Pilar. (2018). Igualdad, representación y violencia de género: el feminismo en las dramaturgas del siglo XXI. UNED. Revista Signa. 617-645

La Vanguardia. La obsesión por Moby Dicky la violencia machista, unidas en una obra teatral. 4-10-2016. www.lavanguardia.com/local/valencia/20161004/41775889595/ 
la-obsesion-por-moby-dick-y-la-violencia-machista-unidas-en-una-obra-teatral. html? facet=amp

Madina, Javier. Perfil psicológico e intervención de los hombres maltratadores. Conferencia. 25-11-2005. San Sebastián.

Melville, H. Moby-Dick. (1851). Macmillan Collector's Library. Ed. 2016.

Moral Jiménez, M. de la Villa \& Sirvent Ruiz C. (2008). Dependencias sentimentales o afectivas: etiología, clasificación y evaluación. Revista española de drogodependencia. 33 (2). 150-167

Red Vecinal. Red Vecinal contra la violencia de género e intrafamiliar. http://www.redvecinal.org/violencia-de-genero/ciclo-de-violencia/

Save the children. Violencia de género. www.savethechildren.es/barometro-infancia/ violencia-genero

Valencia Plaza. La Danza toma parte y revisiona Moby Dick para dar voz a las víctimas de la violencia machista. 4-10-2016. https://valenciaplaza.com/la-danzatoma-parte-y-revisiona-moby-dick-para-dar-voz-a-las-victimas-de-la-violenciamachista

Walker, L. (1979). Battered women: A psych sociological study of domestic violence. Psychology of Women Quarterly, 4 (1), 136-138. 


\section{Capítulo 12 La SubTerránea: teatro poético hecho por mujeres}

Robert March i Tortajada Dept. Filología catalana

Universitat de València

\subsection{Educación para la Igualdad de Género como patrimonio artístico- cultural}

Desde el seminario «Feminismo e Ilustración», el cual consideramos un hito en el desarrollo de la teoría feminista, impartido en 1987 en la Universidad Complutense de Madrid ya se reconoció y manifestó que el mundo y su complejidad social — especialmente multidimensionada en la era de la globalización — solo se entiende echando mano de la teoría feminista. En palabras de Amelia Valcárcel:

\footnotetext{
El feminismo es un conjunto teórico explicativo que da suficiencia a la pensabilidad del mundo. De modo que, una vez rescatada toda la transición de pensamiento y esbozadas las alianzas epistemológicas que lo han ubicado en las coordenadas dialécticas adecuadas, el feminismo siguió evolucionando, especializándose en diversos campos de estudio, y escindiéndose en derivadas teóricas, incluso contrapuestas (Valcárcel, 2014).
}

Desde este enfoque, todas las referencias artístico-culturales que somos capaces de identificar pueden y deben comprenderse como un vínculo emocional, pero sobre todo cívico, entre nosotros y nosotras, pero también con todas aquellas personas que en nuestro pasado reciente o lejano tanto lucharon para sacar la vida adelante en condiciones de dignidad y libertad. Este ejercicio práctico de análisis con «gafas violetas» nos permite entender de manera empática cómo se han pergeñado procesos ciudadanos (a veces singulares, a veces colectivos) en los que muchas personas han ido más allá de su propio bienestar y han encauzado sus esfuerzos y empeño en transformar la sociedad que les había tocado vivir.

Muchos de aquellos impactos nos han permitido avanzar humanamente, y sus logros forman parte hoy de nuestro entorno, de nuestra manera de entender nuestras relaciones en sociedad, de nuestra manera de estar abiertos a las aportaciones culturales de otras gentes con las que convivimos - incluso si no las logramos comprender del todo-, y que nos permite sacar a la luz hechos, vidas, testimonios, expresiones, modos de vida, prácticas, 
objetos, construcciones..., que tanto han contribuido a superar la pobreza, a distribuir la riqueza, a resolver conflictos, o a prosperar en nuestras aspiraciones.

Asimismo, uno de los sentidos de la democratización del hecho artístico-cultural es precisamente el carácter de apropiación (personal y colectiva) de estas referencias simbólicas. Esta apropiación no necesariamente tiene que ver con ostentar su titularidad en términos de propiedad, sino de hacer nuestro algo que pertenece a toda la comunidad universitaria incluida - . Tiene que ver también con la capacidad ciudadana de ir más allá del patrimonio artístico-cultural otorgado, y nuestro poder de identificar «otros patrimonios» $\mathrm{u}$ «otras realidades», y de extraer de su conocimiento interpretaciones válidas para nuestra vida, para nuestro empeño a favor de la educación para la igualdad de género y a favor del desarrollo humano sostenible.

\subsection{La Subterránea. Trayectoria de la compañía}

La SubTerránea ${ }^{34}$ es una compañía de teatro residente en València, fundada como cooperativa en 2013 por Lucía Abellán, Ester Martínez y Lucía Sáez, aunque a partir de 2019 son Lucía Sáez y Esther Martínez quienes están a cargo del colectivo teatral. En 2014, estrenan su primer espectáculo, Pussy Koan, una obra que reflexiona sobre el dolor y la identidad, pero también sobre el deseo y la violencia. En esta pieza, las actrices de La SubTerránea se sumergen en la Ópera Pánica de Alejandro Jodorowski con el objetivo de adaptar la poética del psicomago a una estética que, al fin y al cabo, dotará de cierta identidad a la compañía. En todo caso, tal y como La SubTerránea ha confesado, su aproximación a la mirada de Jodorowski y al teatro de Arrabal llegó a producirse por casualidad. Según La SubTerránea:

Nos acercamos al teatro pánico casi por casualidad y nos hemos quedado por supervivencia
o mejor, por sobrevivencia — aunque la RAE diga que no exista-, porque el teatro pánico
nos sobredimensiona. No nos identificamos con un movimiento pánico si es que lo hay
—aunque esto mismo supondría ir a contracorriente-. Tomamos del pánico la libertad, la
alegría de gritar con la boca bien abierta, la forma de experimentar y de hacer, las sesiones
infinitas y locas —a veces de varios días-, el humor, el disparate y la euforia, el símbolo,
lo vulgar y lo sublime, lo cruel, la tragedia común y la poesía... y seguro que más cosas que
aún no sabemos. [...] Hacemos nuestra una máxima de Arrabal y del teatro pánico: «es la
crítica de la razón pura, es la pandilla sin leyes y sin mando [...] es el himno al talento loco,

\footnotetext{
${ }^{34}$ La SubTerránea ha mostrado su trabajo en salas como Espacio Inestable, Teatro Círculo, Sala U1tramar y Sala OFF, Teatro Principal de Requena. Asimismo, han participado en el festival Estrénate (CICUS, Sevilla), Reclam (Castelló), Escènia 2016 (Foios), la Muestra de Teatro de Alcoy, Tercera Semana (València y Castelló) y Muestra de Autores Contemporáneos (Alacant). Han sido galardonadas en Escènia 2016 con el Primer Premio del Jurado y el premio Mención Especial del Público por Martingala. Con el premio Punto G al mejor espectáculo de 2017 en València por Maldito Otoño. Maleïda Tardor. Han sido finalistas en los Premios Max 2018, en las categorías de «Mejor obra revelación» y «Mejor autoría revelación». También, en 2018, fueron nominadas a los Premios de la Crítica Valenciana por su obra Martingala. Además, tanto Martingala como Maldito Otoño. Maleïda Tardor han sido publicadas por Alupa editorial, que apostó por la publicación de textos teatrales y que cerró sus puertas en los primeros meses del 2019.
} 
es el antimovimiento, es el rechazo a la seriedad, es el canto a la falta de ambigüedad; es el arte de vivir que tiene en cuenta la confusión y el azar, es el principio de indeterminación con la memoria de por medio... y todo lo contrario» (La SubTerránea 2015, p. 9).

De este modo, con Pussy Koan y su mirada hacia el teatro pánico, La SubTerránea inicia una andadura teatral en la que apuesta por cierta ruptura con el teatro más convencional. Según las creadoras, su inicio fue:

Tal vez ese fue el inicio de ir descubriendo una manera propia de trabajo: romper, sin miedo al vacío de después. Esa es una buena costumbre que se nos ha quedado. No somos cobardes ni en la creación, ni en la destrucción. Si algo no funciona, se tira. [...] Perseguimos la verdad — nuestra verdad — desde el inicio, esto es, desde el momento mismo de escoger sobre qué vamos a tratar.

A continuación, se puede observar una imagen de la pieza Pussy Koan donde la actriz Lucía Sáez realiza un vuelo poético.

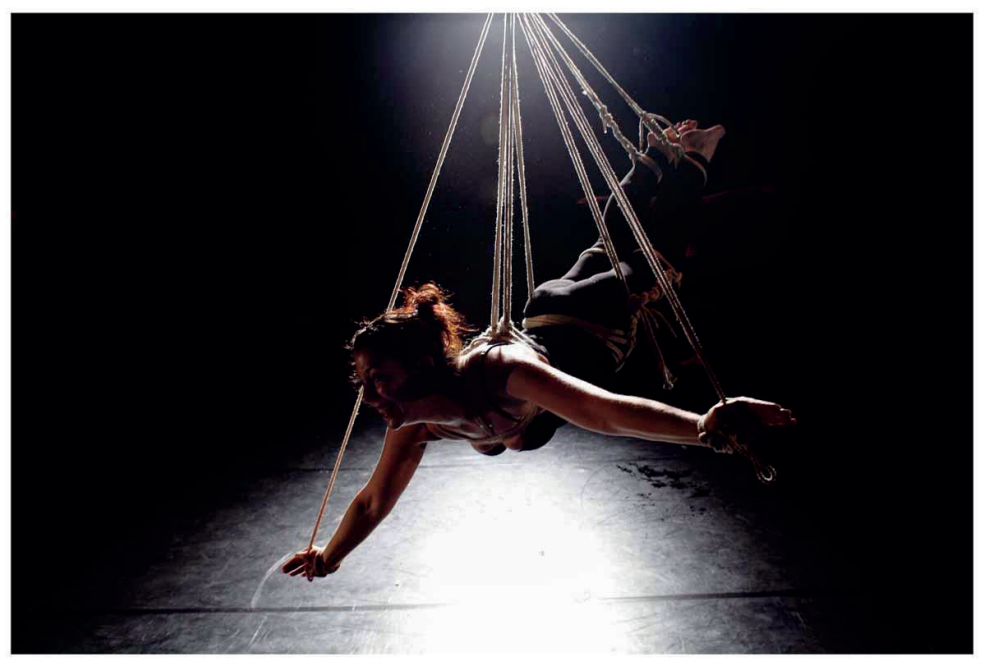

Fotógrafo: Jordi Pla (2014)

Imagen 1. Pussy Koan

\section{Fragmento de Pussy Koan:}

MARTÍNEZ: Cierra los ojos, y mira. Mira esas filas de gentes ordenadas, razonables, haciendo cola. Esperan su turno para el transporte público, para conseguir plaza en la universidad, en la oposición, para recibir su primer beso; aguardan ante la taquilla de un espectáculo cualquiera.

Estamos aquí y es primavera, todo está bien, y por un momento la vida promete ser amable. Pero cierra los ojos más, y mira mejor. Son las mismas colas del pan y del racionamiento, en cualquier lugar las mismas gentes, humilladas, razonables: interminables filas de prisioneros provenientes de cien ejércitos distintos, pero todos igualmente derrotados. Sabes, son muchas, demasiadas las veces en las que no puedo dejar de verlo así. 


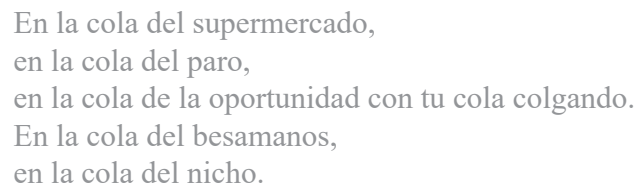

Sabes, a menudo en mi cabeza suena feroz y persistente un tambor como de guerra: ese tamtam que convoca a las gentes fugitivas para que se busquen y se encuentren, anunciando que la grieta crece, que cuidado que crece, que a lo mejor está bien que crezca. Ese tam-tam que convoca a las gentes fugitivas para que se busquen y se encuentren.

Entonces, tanto da. Da lo mismo: da el mismo miedo.

¿Cuánto miedo te cabe en la boca?

¿Qué puede pensar alguien obligado a demorarse en una formación, con los ojos fijos en la nuca de quien le precede, ofreciendo la suya al que viene detrás, mientras la muerte va cantando su monótona victoria? (La SubTerránea, 2013, p. 2-3. Inédito)

Un año después, en 2015, la compañía entra a formar parte del proyecto de Residencias de la sala Espacio Inestable. Esta experiencia les permite crear Finisterre o vencer al Chupacabras, un proyecto que, desde su mismo estreno, sufrirá una transformación bien importante, ya que, como work in progress, pasará a estrenarse como Martingala (2016), una pieza que aborda la manipulación mediática - a nuestro juicio, la mejor obra que La SubTerránea ha realizado hasta la fecha-, conservando, eso sí, un par de guiños escénicos de la Finisterre inicial y, por supuesto, sin abandonar el interés por la poética de Jodorowsky y las imágenes de Roland Topor. La siguiente imagen corresponde a la escena de «La vida nos separa», de Martingala. En ella, las actrices representan y viven un momento de rebelión social en el que debaten qué hacer con su existencia.

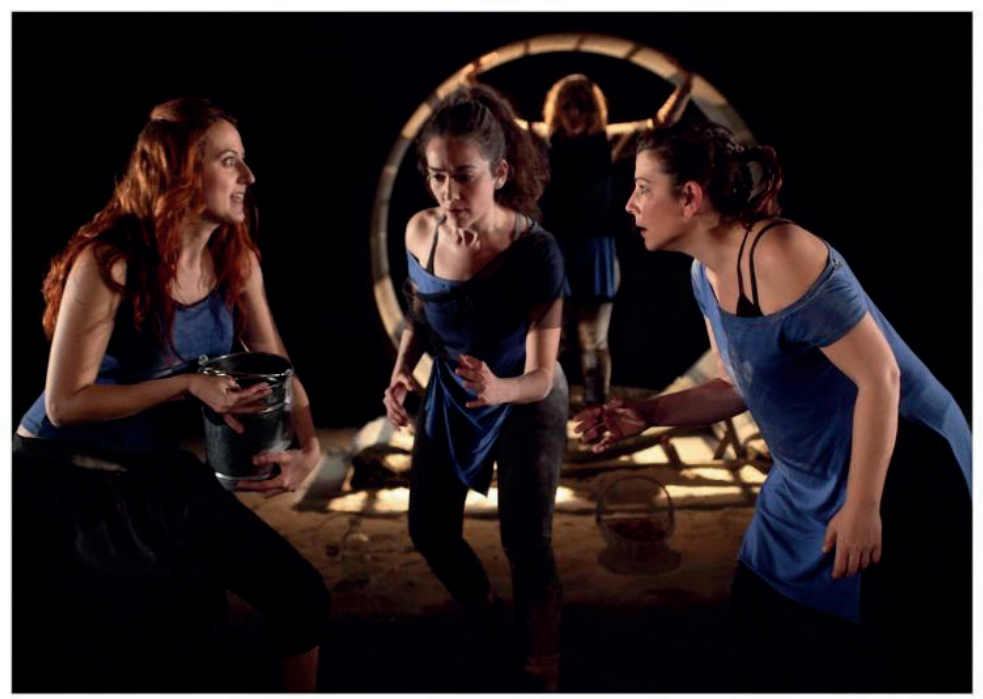

Fotógrafo: Jordi Pla (2016)

Imagen 2. Martingala 
El inicio de Martingala, concretamente, la acotación que engloba toda la acción de «Medea y su ejército de hijos» —nótese la repetición metafórica del concepto ejército de la cita anterior de Pussy Koan -, nos dibuja la siguiente imagen poética (ver imagen 2):

\begin{abstract}
Medea, gélida, madre creadora, mitad centauro mitad cíclope -con los senos cableados y conectados a extractores de leche- sacrifica todo lo que crea en centro de la escena. Tras ella, se adivina una gran rueda metálica. A sus pies, el suelo está cubierto por montañas de harina, botellas de leche, platos, huevos y unos bultos que respiran. Y el mundo entero.

Medea, en medio del frío, alumbra al mundo dos huevos, que nacen de sus axilas. Contempla su creación y sale de escena. A su imagen y semejanza da vida a dos cachorros. Estos huelen su ausencia. Buscan leche materna y la encuentran en los cables que Medea se ha quitado de los senos. A través de estos, la engullen y, a medida en que el alimento surte efecto, se incorporan. Con las últimas gotas de leche llega la lucha.

Los cachorros acechan en busca de alimento. En mitad de la lucha, la harina se eleva en el aire. Todo es supervivencia, revuelo, corro. Ríen, juegan y pelean por la leche. Y eligen a uno de los cachorros como a su gallinita ciega. Esta asume su papel. Se alegra y gira. Ciega, busca lo que se le ha perdido. Ríe sin descanso y gira hasta que el juego se torna turbio y el giro violento. Como una letanía se oye cantar «gallinita ciega qué se te ha perdido.» La gallinita queda sola en la escena, gira como una peonza hasta que cae rendida (La SubTerránea, 2017, p. 15).
\end{abstract}

En su proyecto siguiente, La SubTerránea vuelve a ser seleccionada en los Graneros de Creación del Espacio Inestable, experiencia que, en este caso, permite a las creadoras desarrollar Maldito Otoño. Maleïda Tardor, una obra que piensa la vida y sus límites, con la intención de reflexionar acerca de la presencia de la muerte, pero también sobre su ausencia en el discurso, digamos, occidental. En Maldito otoño. Maleïda tardor, La SubTerránea cuenta con la colaboración del dramaturgo Paco Zarzoso, concretamente, como codirector de la misma. Esta sinergia se ha repetido también en Federico, la última creación de la compañía.

ABELLÁN: Pasa la vida entera y luego... luego ya sí que no.

ESTER: ¡Que no! Que luego ya no, ¡no!, que pasarán más cosas...

SÁEZ: Pasa la vida en tierra, y luego ya no.

ESTER: ¿Pasa la vida en tierra y luego ya no?

ABELLÁN: Pasa el tiempo y luego... luego ya «colorín colorado».

SÁEZ: Que no, que no tenemos tiempo ni para el «Érase una vez...».

ESTER: Ni para el «érase una vez» ni para «el colorín colorado», que no tenemos tiempo, que pasan los otoños y se nos deshidrata el pellejo, que pasa y nos convertimos en pasas. Que pasa, que pasa...

SÁEZ: ¿Qué pasa? Pasan los otoños, las cosas secas, pasa la vida entera. ¿Y luego? ¿Luego ya no?

ESTER: Luego ya no, luego ya no... ¿Qué es eso de que luego ya no?

ABELLÁN: ¿A ti te han dicho alguna vez que te vas a morir?

(Dejan de oírse el pasodoble y la risa. La fiesta concluye brusca y solo queda el silencio. Se dirigen a la mesa del centro, se miran y se acusan con los ojos.) 
ESTER: ¿Qué?

SÁEZ: Que luego ya no.

ABELLÁN: Y a ti, ¿te lo han dicho?

SÁEZ: ¿El qué?

ESTER: Que luego ya no, que... «Colorín colorado».

ABELLÁN: Que te vas a morir (La SubTerránea, 2017, p. 25-26).

Otra pieza de gran interés es Urbach-Whiethe, en este caso, puesta en escena para la edición del Festival Russafa Escènica 2016. Hablamos ahora de una obra de teatro breve la más corta que la compañía ha desarrollado hasta el momento, pero no por ello carente de intensidad dramática — en la que las actrices, bajo la temática del miedo — propuesta lanzada por el Festival para todos los proyectos de esa edición-, reflexionan sobre la enfermedad de Urbach, caracterizada por la ausencia de miedo como consecuencia de tener la amígdala dañada, y nos invitan a que dañemos la nuestra. De este modo, La SubTerránea estimula al público para que piense en sus propios temores y en sus pulsiones. En definitiva, Urbach-Whiethe se presenta como una indagación acerca de aquello que nos asusta, que nos inquieta y nos da pavor, que puede, en algunas ocasiones, no estar a mucho más de un metro y medio de distancia o, al menos, así se nos presenta en esta obra teatral. Por lo que se refiere al espacio, la puesta en escena tuvo lugar en una galería de arte del barrio valenciano de Russafa, concretamente, para no más de veinte espectadores; escenario, además, idóneo, en la medida en la que las distancias cortas favorecían la experiencia teatral y, a su vez, el carácter de intimidad y, por extensión aquí, la posible aparición del miedo, como hemos señalado, propuesta por la organización del festival:

SÁEZ: El miedo pesa.

ABELLÁN: El miedo mide.

(Abellán apunta a Sáez con una linterna, mide con el haz de luz la distancia que las separa. La sombra de Sáez se proyecta, pictórica, sobre la pared. Con los tacones en la mano, Sáez lucha por no caer al suelo. El miedo le pesa tanto que apenas puede sostenerse sobre sus propias piernas. Intenta bailar sobre él, venciendo el vértigo del desequilibrio a cada paso.)

SÁEZ: El miedo pesa. Da igual donde lo guardes, que pesa. Yo tengo miedo en las piernas, y es por eso lo de las varices y las piernas pesadas, porque el miedo pesa. Y es por eso, porque pesa y está en las piernas, que creo que no bailo bien, y que si te fijas son un poco gordas en comparación con el resto del cuerpo, y que no he ido a todos los sitios que me gustaría, porque tengo miedo en las piernas. Desde hace seis años tengo las mismas zapatillas de caminar-viajar, y yo creía que porque eran de marca, pero no, es porque no he ido a tantos lugares como me habría gustado porque tengo miedo en las piernas. ¿Nunca has deseado romperte la amígdala?

ABELLÁN: El miedo mide.

SÁEZ: El miedo pesa.

ABELLÁN: A veces mide justo la distancia que separa mi cuerpo del tuyo, porque no me atrevo a decirte... Justo esta distancia (Señala con el haz de luz de la linterna) que no sé cuánta es, pero justo esta.

SÁEZ: El miedo pesa. 
ABELLÁN: A veces mide un metro y diez centímetros, lo que necesito para extender la mano a un desconocido. Lo que está claro es que si mide, separa. Aunque también prefiere las distancias cortas, porque miedo de lo que pasa a once mil kilómetros no tienes, tienes miedo de que te pase eso mismo pero a un metro y diez centímetros de distancia (La SubTerránea, 2016, p. 5. Inédito).

En el marco del Festival 10 Sentidos, en 2018, La SubTerránea estrena Ser Visibles, pieza que permite a la compañía realizar un giro procesual. De hecho, si hasta el momento tanto sus proyectos teatrales como sus intereses se habían centrado en un teatro desarrollado a partir de procesos creativos generados por la misma compañía, Ser visibles permite a La SubTerránea abrir su creatividad al otro, a la escena social, tal y como lo indicaban las actrices acerca de este proceso de creación:

En estos días, trabajamos con personas con diversidad funcional, transgénero, inmigrantes, personas que habían padecido violencia de género, y también con jóvenes estudiantes de arte dramático. Nos interesa el trabajo conjunto de todos en un proceso de creación artística e individualizarlos ahí, para la no significación de los «dramas» asociados a cada colectivo. Ampliar el «horizonte» de cómo vemos a las personas - y cómo nos vemos a nosotros mismos - para ampliar la libertad de miras y de actos que nos permitimos a nosotros y a los demás. Abrirnos a un proceso de retroalimentación y cuidado que, entre tanta riqueza diferencial, será sumamente enriquecedor.

La creación de un espectáculo donde los participantes se presenten como deseen ser vistos, rompiendo los esquemas de los horizontes que cada uno ha trazado —o le han trazado- en su mente. Rompiendo previamente el horizonte propio. En definitiva, crear nuevos horizontes más cercanos y abolir esa línea recta que casi siempre está construida de prejuicios (March, 2020. Entrevista inédita).

Esto es, si bien la compañía es consciente de cómo el teatro tiene un poder sanador e integrador, es en esta pieza donde la compañía valenciana pone al servicio del otro su práctica. Asimismo, Ser visibles no será la última experiencia de teatro social. En todo caso, en ella, participarán alumnos de la Escuela superior de arte dramático (ESAD), personas con movilidad reducida, transgénero, mujeres víctimas de violencia de género e inmigrantes. La puesta en escena de la obra se realizará en la Plaça de l'Ajuntament de València. En todo caso, el papel de La SubTerránea será el de hacerse cargo tanto del proceso como de la dramaturgia. De este modo, a diferencia de los proyectos anteriores, Ser visibles será la primera obra en la que nuestras creadoras no participarán de la interpretación, pues la intención de La SubTerránea aquí no es otra que dejar que el otro sea quien ocupe toda la escena.

FRANCISCO: Me llamo Francisco. No llevo la cuenta de las veces que he sido invisible, tampoco me hace falta, esa es la verdad. Me preocupo más de ver que de que me vean, hago teatro en un grupo de la Once, Samaruc, y allí sí que sabemos ver, ver de verdad. No hacen falta ojos para ver, ni para ser visto. El órgano de la vista es el corazón y Carmen lo sabe.

FRANCISCO Y CARMEN: ¡Azúcar!

ANA: ¿Veis esa chica de ahí? La de rizos y una sonrisa que podría iluminar esta sala. Sí, ella. Ella es Estela. Para mí ella es la palabra que más gracia le hace: cacahuetes. Quiero decir: ¿Sabéis cuando una cerveza bien fresquita viene acompañada de un platito de cacahuetes? Es algo que esperas que llegue pero que cuando llega te sorprende y te hace sonreír. 
Ella es ese plato de cacahuetes: llega de manera inesperada y se te dibuja una sonrisa. Ella es fragilidad y fortaleza, como el mar y la música. Para mí ella es eso: mar y música, y iqué casualidad!, resulta que son las cosas que más le gustan. Estela, tú eres como lo que ves en el mar y en la música. Que no se te olvide. Tienes la fuerza de las olas, la tranquilidad de un mar en calma, el ritmo de la música, la armonía de unas notas de blues y lo improvisado del jazz. Creo que a veces se olvida de que todo eso está dentro de ella misma y lo busca fuera. Me gustaría que se viese como la vemos los demás, como la ve su persona favorita en el mundo: su madre. A Estela le encantaría viajar a una lista interminable de lugares. Cuando emprendas tu viaje a África, Nueva Zelanda, París, Tailandia, La India... a cualquier lugar que te apetezca conocer, pide que el camino sea largo, lleno de aventuras, lleno de experiencias. Que muchas sean las mañanas de verano en que llegues — icon qué placer y alegría! - a puertos nunca vistos antes. A lugares donde no exista la injusticia, el machismo, el conformismo de la sociedad, ni la gente que no sabe abrir la puerta de los metros. Ve a muchas ciudades a aprender, a aprender de sus sabios. Mas no apresures nunca el viaje. Mejor que dure muchos años y atracar, vieja ya, en la isla de Tenerife o Lanzarote. Y déjate caer allí, allá donde el mar te rodea, introduciendo tus manos en la arena hasta que las cubran por completo. Déjate caer allí, allá donde más a gusto te sientes, con tu guitarra, con tu música, bajo la luna gitana, y sin que ningún ruido de obras entorpezca que el sonido de las olas llegue a tus tímpanos... Déjate caer allí, allá donde juegan tu boca y los ecos. También nos gusta que nos cuiden y que nos toquen el pelo y que nos abracen mucho, con todo el cuerpo. (Todos se abrazan más.) A todos nos encanta besar, mirarnos a los ojos, compartir las fotos, decirnos lo bien que hacemos las cosas, hacernos bromas, sacarnos a bailar y hacernos cosquillas, hacernos cosquillas, hacernos cosquillas, hacernos cosquillas, hacernos visibles y hacernos cosquillas. (Todos se hacen cosquillas.) Hacernos cosquillas hasta reconocernos en mitad de las risas y convertirlas en grito de guerra. ¿Que no pasa nada! (La SubTerránea, 2018, p. 10-11).

En una línea similar, nacerá Como las cosas amables, en este caso, una obra de teatro en la que colaborarán alumnos de La escuela del actor y usuarios de la Asociación ACOVA, una asociación de ayuda a personas con enfermedad mental de la Comunidad Valenciana, como usuarios de la ONG Hogares compartidos. El texto de presentación de Como las cosas amables es el siguiente:

Cierra los ojos. Imagina catorce personas con diferentes nombres y apellidos dirigiéndose hacia el final. Un horizonte en obras, apenas visible, demolido por la grúa del buenismo y la contaminación.

Abre los ojos y deja de imaginar. Ahí están esos catorce pares de pupilas inquietas, renacentistas, en patinete, en chándal o con móvil. Precipitándose al vacío de unos ojos que les miran fijamente. A veces reciclan y dicen toda la verdad; otras son republicanas o no y son mentirosas.

Estamos en la terraza de un bar y es primavera.

¿Cómo pedimos la tortilla, con o sin cebolla? (La SubTerránea, 2018. Inédito).

El siguiente proyecto escénico es Federico (2019). Esta producción es la primera incursión de La SubTerránea en el teatro familiar. La obra nos habla de una muchacha que busca a Federico García Lorca, que en el texto es presentado como su abuelo, como el abuelo de todos los poetas. En todo caso, es una invitación para que el público de más edad no olvide que en un momento fue niño, pero, sobre todo, para que se haga cargo del 
pasado colectivo. Federico es, por ello, una obra de memoria histórica contada para los jóvenes, eso sí, con la poética a la que La Subterránea nos tiene acostumbrados. Por ello, a nuestro entender, tanto esta pieza como también las anteriores pueden ser entendidas como teatro político, no ya por la explicitud o no del mensaje que el espectador pueda obtener a través de los diferentes textos y propuestas escénicas, sino en la medida en que las formas, la poesía escénica es abordada en el escenario. De hecho, la explicitud o la univocidad no es una marca que caracterice la teatralidad en La SubTerránea, a excepción, quizás, de aquellos casos en los que la compañía indaga, por ejemplo, en el humor o la sátira. La imagen que presentamos a continuación, corresponde a Federico, en esta escena Bernarda impide que la protagonista de la obra recite unos versos de Lorca, concretamente, por miedo a la represión y al qué dirán. En todo caso, la protagonista (Ella), a la par que trata de encontrar al poeta, busca su lugar en el mundo. En fin, una escena que representa tres generaciones de mujeres: la infancia (representada en el títere), el paso a la madurez (en la protagonista) y la mujer adulta (Bernarda).

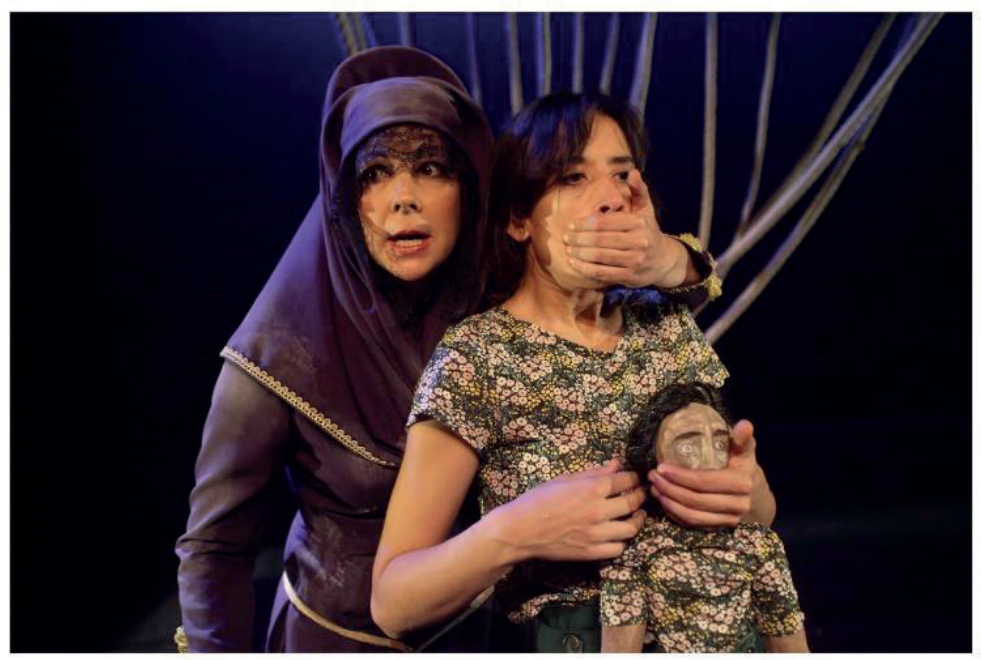

Fotógrafo: Jordi Pla (2019)

\section{Imagen 3. Federico}

Asimismo, Federico es la obra más intertextual de la compañía. En ella, el proceso de escritura se desarrolla a modo de diálogo con la poesía lorquiana y, obviamente, también con su obra dramática.

\footnotetext{
Vivimos el teatro como un organismo abierto a cualquier disciplina. Así como cualquier organismo de la naturaleza bebe agua de cualquier lugar sin preguntarse si es una fuente, un río o un pozo; si tenemos sed de una disciplina, de un lenguaje, bebemos. Confiamos en que el propio proceso nos indique aquello que mejor apoye y potencie lo que queremos decir. Nos acercamos a la mano todas las herramientas que podemos, cogemos de aquí y de allá: de las disciplinas del cuerpo — la danza, el teatro físico-, de la poesía y la prosa, de cualquier manifestación musical, de cualquiera de las artes plásticas y el audiovisual —con
} 
el que empezamos a experimentar en este nuevo proyecto-, y de la performance y el happening, que siempre nos dan muchas alegrías. (La SubTerránea, 2015, p. 9).

De hecho, si en la dramaturgia de Federico encontramos un sinfín de guiños al poeta de Granada, también es cierto que La SubTerránea dota al texto de una poética escénica propia, en la que diferentes personajes lorquianos aparecen unos con otros y, sobre todo, a modo de un sueño onírico. En esta línea, encontramos diferentes personajes femeninos como la Luna y Bernarda, pero también a unos títeres de cachiporra y a un agente de la Guardia Civil. En Federico, la niña realiza un viaje cuyo recorrido va desde la calle en la que juega a la comba hasta Fuente Vaqueros o, incluso, a Nueva York o la casa de Bernarda Alba. El fragmento que presentamos a continuación contiene referencias directas a los poemas lorquianos de «Dos muchachas», «Balada interior» y del cuento «El niño mudo». Las citas corresponden a los versos en cursiva y remiten a los textos de Lorca indicados. En todo caso, en Federico la acción tiene lugar frente a un olivo, concretamente, en la casa de Bernarda Alba:

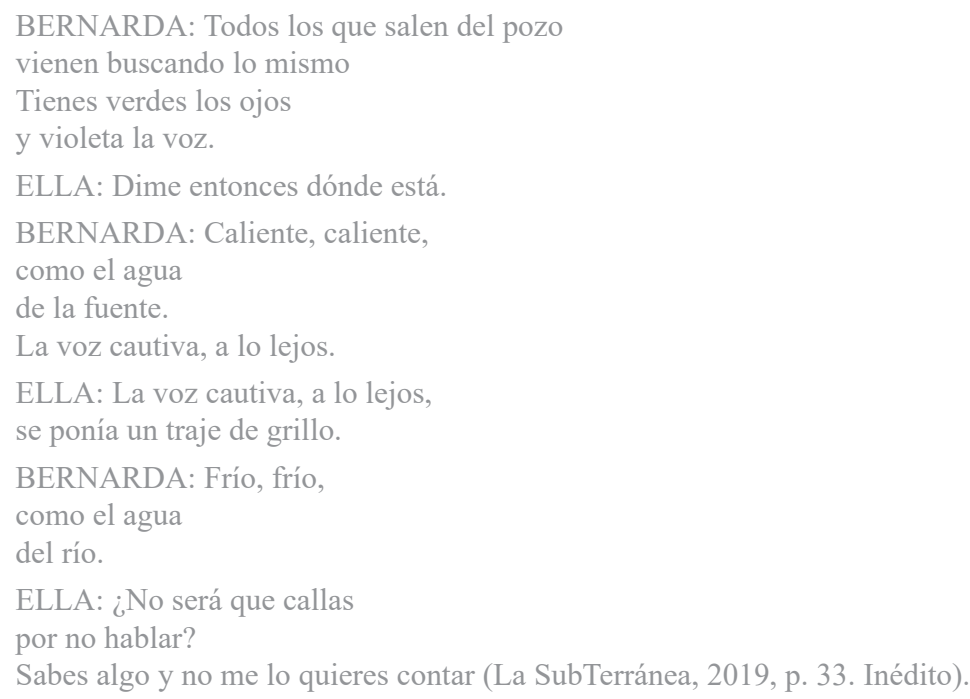

\subsection{Procesos escénicos y metodología}

La SubTerránea aborda sus propuestas desde la creación colectiva. Definir el trabajo escénico de esta compañía no es una tarea fácil pero, tal y como las actrices han destacado en más de una ocasión, hablar de su trabajo puede llevarnos a adentrarnos en una búsqueda constante. Es decir, una indagación sobre las posibilidades de la escritura y las nuevas dramaturgias y, sobre todo, acerca de las multiplicidad de lenguajes escénicos, eso sí, bajo el prisma del compromiso social y la poética. De hecho, como hemos apuntado anteriormente, en los espectáculos de La SubTerránea la reflexión y la poesía, pero también el humor, conviven en perfecta armonía. 
Creemos firmemente en la poesía escénica. Poesía literaria y poesía visual, o dicho de otro modo, la plástica de las imágenes. Como amantes de la poesía contemporánea nos gusta investigar y descubrir nuevos poetas, poetas vivos, poetas de la calle, de nuestra generación o de la generación de al lado; de ellos bebemos constantemente sin ningún pudor ni empacho. Sus poemas a menudo nos alumbran, nos despiertan y provocan, y son la chispa que arranca el motor de nuestra creación literaria. Wislawa Szymborska, Gioconda Belli, Escandar Algeet, Carlos Salem, Isabel García Mellado o Alicia Es. Martínez, por mencionar solo algunos (La SubTerránea, 2015, p. 8)

Para La SubTerránea, residir es crear un nido. Es generar un lugar seguro de libertad en el que exista la posibilidad de desaprender, nacer y destruir. Experimentar, al fin y al cabo, diferentes procesos vitales, que, con el tiempo, son traducidos en proyectos escénicos. Con algunas diferencias, este proceder se nos asemeja al trabajo que desarrolla la compañía teatral de El pont Flotant, sobre todo, por lo que a las obras más sociales de La SubTerránea se refiere. En todo caso, la indagación a la que nuestra compañía somete sus piezas es, entendemos, la de pensar el cómo habitamos el tiempo, la vida, donde la cultura ha llegado a ser mero plato de consumo: una sopa boba en Martingala. En fin, la búsqueda por el aprovechamiento del instante y la contemplación, si cabe, frente a la conjugación del verbo producir mientras la palabra cainita dialoga con el abismo.

Tal y como hemos apuntado en las primeras líneas de este texto, La SubTerránea ha tenido la posibilidad de disfrutar de diferentes residencias teatrales, oportunidades que han permitido a las creadoras de la compañía poder desarrollar sus proyectos escénicos, digamos, al ritmo de cocción que el proceso teatral ha exigido en cada momento. Según confesaba en una entrevista reciente Lucía Sáez:

Una residencia nos ofrece ese valor, el tiempo. Tiempo para experimentar, para sobrepasar límites, para soñar, para arrepentirnos de lo creado y volverlo a crear, para buscar, en fin, formas, maneras, caminos y contenidos. Hasta el momento, nuestra metodología presenta puntos en común en los diferentes procesos creativos en los que hemos trabajado que no perdemos de vista, cosa que no quiere decir que no nos dispongamos a sumergirnos en otras formas de trabajo. (March, 2020. Entrevista inédita).

Un tópico metodológico que las creadoras de La SubTerránea parecen considerar en todo momento es la idea de desestructurar aquello que, en principio, presenta una apariencia firme. Es decir, la resistencia a verse encorsetadas por las formas de una dramaturgia que pueda frenar una creación más libre, pues para La SubTerránea el instinto y la experiencia han de convivir en equilibrio. Prácticamente desde su fundación, la compañía ha venido trabajando bajo un principio que puede encontrarse no ya en la gestación de cada uno de sus proyectos, sino en los diferentes resultados escénicos. Este principio no es otro que el de entender toda creación como el espacio donde el yo se hace presente al otro, se visibiliza:

En nuestras propuestas escénicas, cuando creamos a partir de nosotras, a partir de nuestro yo, no hablamos de un yo narciso. Aquello que, en cambio, nos inquieta, es hablar desde lo que nace desde nuestras entrañas, cosa que muchas veces es hacerlo a partir de las cosas más sencillas. Es decir, intentamos ir más allá de nuestras experiencias individuales para comulgar con el otro, justamente, para compartir aquello que puede sernos común, 
sentido, afectado. Cuando creamos investigamos y, con ello, tratamos que nuestra experiencia individual, aquella, quizás, más íntima, se muestre en escena — puede que a modo de confesión-, con la intención de compartir esa experiencia con el público (March, 2020. Entrevista inédita).

Asimismo, a este principio cabe sumarle otros que están presentes en cada una de sus propuestas escénicas y, por extensión, en cada uno de sus trabajos desde el proceso creativo en sí. Hablamos, de hecho, de cuatro patas que para La SubTerránea resultan soportes innegociables y fundamentales: la honestidad, la metáfora, el reto y la poesía escénica.

Por lo que se refiere a la primera, las creadoras de La SubTerránea huyen de cualquier acción que las aleje tanto de la realidad como de su propia intimidad. De este modo, desde la investigación que desarrollan en sus procesos creativos y la posterior puesta en escena, realizan un ejercicio de sinceridad escénica. No obstante, eso no quiere decir que a partir de sus experiencias personales no exista una dramaturgia, de hecho, esta nace ya desde el mismo proceso creativo y, además, se somete a una reescritura prácticamente constante hasta que la pieza teatral está cerrada. Asimismo, si bien las mujeres de La SubTerránea escriben sus textos, en un principio, de manera individual, esta práctica pronto pasa a un segundo nivel, que es colectivo. En otras palabras, todas reescriben los textos de las demás, asunto que desdibuja ese yo que comentábamos anteriormente y, a su vez, enriquece y hace más complejo, si cabe, el texto final.

El uso que de la metáfora hace La SubTerránea sigue un camino similar, pues el objetivo que persiguen las dramaturgas no es otro que compartir su individualidad con la singularidad, también, de cualquier espectador. Esto es, parten, como puede entenderse ya, de su yo más íntimo para tenderle la mano al espectador con la intención de que este quede afectado, es decir, conmovido por la experiencia teatral. En todo caso, si bien en muchas ocasiones en las propuestas escénicas de La SubTerránea la violencia está más que latente, el espectador es tratado con el máximo respeto. Es decir, no se le importuna bien si hay o no un franqueamiento de la cuarta pared, simplemente se le invita a que sienta su experiencia teatral, a que la viva. Asimismo, tanto la honestidad como el trabajo con el mundo de lo metafórico y lo figurado permiten a La Subterránea obtener unos resultados escénicos en los que el espectador, como hemos señalado ya, ha quedado conmovido, y este es parte del reto que anotábamos más arriba.

\footnotetext{
Apostamos por jugárnosla desde el minuto uno de la creación hasta el momento de la representación en escena. El reto y la dificultad siempre están presentes. Comenzamos tomando riesgos desde que asumimos que vamos a hablar de algo que nos interese y nos conmueva desde lo más íntimo y que nos vamos a mojar al hacerlo. Como ya habíamos mencionado antes, abordamos el tema escogido desde un lado completamente personal, lo que implica compartir vivencias, frustraciones, anhelos, terrores... y sobre todo, dejar caer la máscara para verse bien por dentro y mostrarse a las demás. Apreciamos la vulnerabilidad y por eso nos cuidamos y nos amamos, con todo lo que significa. Nos gusta que nuestra relación personal esté cuidada y alimentada y sabemos que escénicamente es importante y trasciende. Sin ese cuidado, que el sentirse vulnerable exige, no estaríamos en posición de asumir ningún riesgo (La SubTerránea, 2015, p. 8-9).
} 
Nuestras actrices y dramaturgas son bien conscientes del carácter político que encierra toda palabra, más si cabe la teatral, asunto que les permite, justamente, prestar atención al logos con la intención no ya de generar un vínculo emocional desde la interpretación, sino de la búsqueda que trata de potenciar el resultado final. Esto es, no solo hablamos de una encarnación más o menos visceral, sino de una estética como consecuencia de una poética teatral, que es sentida - vivida - desde el interior de la escena. Asimismo, para las actrices de La SubTerránea, la poesía es camino y la guía con la que hilvanar lo plural y lo particular, lo individual, en resumen, con aquello que puede ser compartido. Es decir, la intimidad política (Pardo, 2012) de la singularidad con lo universal (Nancy, 2006). Un ejemplo de esta poeticidad lo encontramos, de nuevo, en Martingala, concretamente aquí en una escena en la que la actriz se confiesa culpable de pertenecer al mundo que habita, pues este le genera esa misma culpabilidad. Por ello, a modo de liberación se confiesa consigo misma delante del público mientras realiza una coreografía.

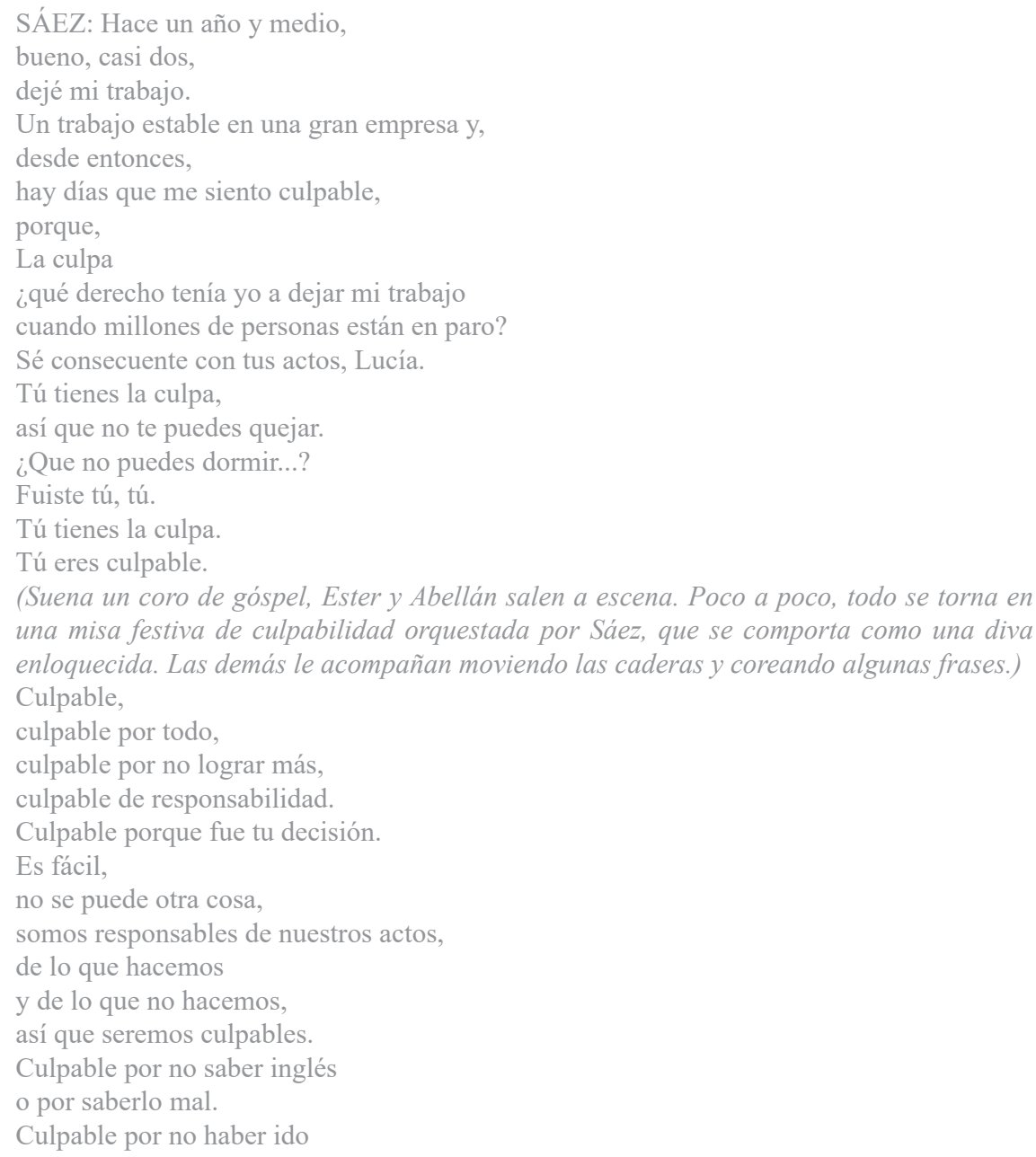


suficientes veces a la piscina.

Culpable por no haber logrado más en mi carrera artística, yo no sé cómo se mide eso. Escucha esta historia.

ESTER: Listen to the story.

ABELLÁN: La gran rueda siempre está girando.

SÁEZ: O no haber ido a ayudar a los refugiados.

¿Qué derecho tenía yo?

¿Qué puedo hacer yo desde aquí?

¡Culpable por llorar!

¡No puedes llorar!

¡No tienes derecho a llorar,

no te puedes quejar!

Culpable por comer.

Culpable cuando se me pudre

alguna fruta en la nevera.

Culpable por tirarla a la basura.

Culpable por desear tener un móvil último modelo.

Culpables, nos sentimos culpables por todo.

Por fumar, por no hacerlo,

por ver muchas horas la televisión

-yo suelo ver la televisión-.

Culpables, somos culpables de querer demasiado, de odiar,

de llegar tarde $\mathrm{y}$, a veces,

demasiado pronto.

Culpables por quedarnos en casa y no salir

o culpables por salir demasiado.

No hay término medio,

ese es el objetivo:

que todos seamos culpables.

Culpables de asfalto, de alquitrán, de algodones

y mascletaes de último diseño.

Culpables por vivir por encima

de nuestras posibilidades.

¿Cuáles fueron mis posibilidades?

¿Cuáles son mis posibilidades ahora?

Culpables por no luchar más.

¿Cómo puedo luchar?

Culpable por querer mandarlo todo

a tomar por culo

y montarme un huertecito ecológico

alejado de todo

y de todos.

Culpable por no saber plantar ni un tomate.

Culpable, porque te odio

cuando me doy cuenta 


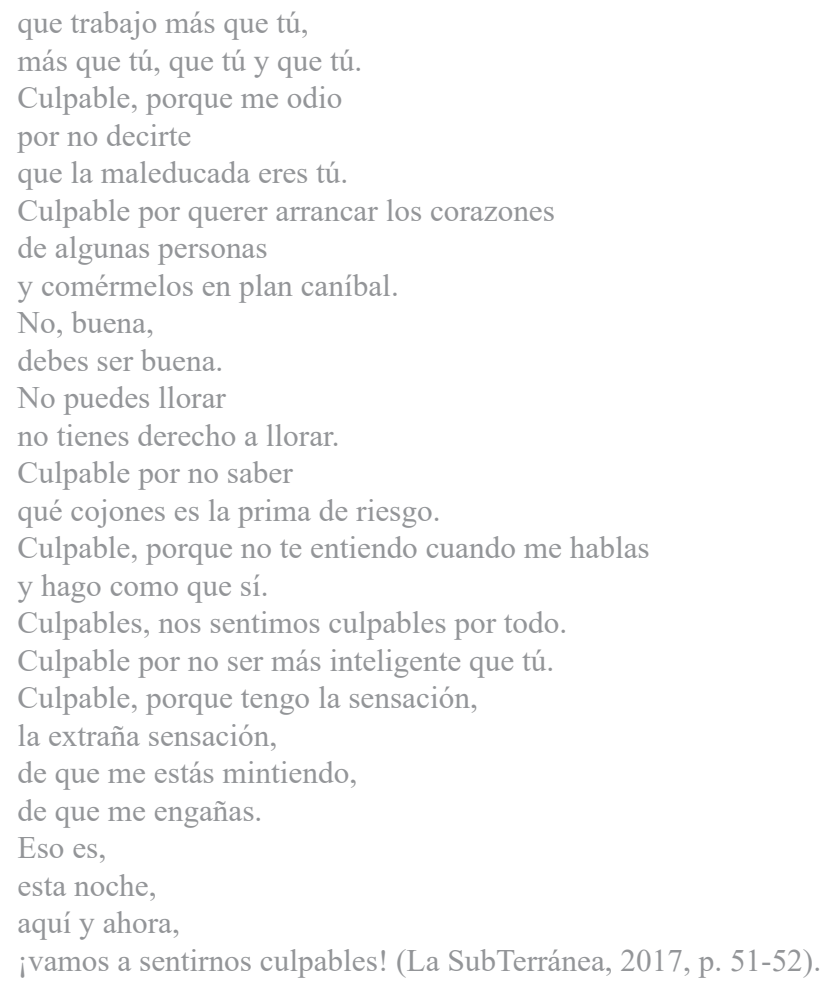

En definitiva, el teatro de La SubTerránea es un teatro que en sus procesos de creación confía en su intuición y, si bien es cierto que nuestras actrices tienen una más que importante experiencia y conocimiento en la técnica teatral, su apuesta es la de liberarse de ellas mismas. En otras palabras, que la interrogación, la investigación y la libertad se presente en el proceso creativo con tal de que sea palpable en el resultado escénico. Y en todo ello vive y habita lo poético. Lo que está detrás. Lo subterráneo.

\subsection{Referencias bibliográficas}

Dubatti, Jorge (2010). Filosofía del teatro II. Cuerpo poético y función ontológica. Buenos Aires: Atuel, 2010.

Deleuze, Gilles y Félix Guattari (2008). Rizoma. València:Pre-textos.

Didi-Huberman, Georges (2012). Supervivencia de las luciérnagas. Madrid: Abada.

Didi-Huberman, Georges (2011). Lo que vemos, lo que nos mira. Buenos Aires: Manantial.

Garces, Marina (2002). En las prisiones de lo posible. Barcelona: Bellaterra.

La SubTerránea (2019). Federico. Texto inédito.

La SubTerránea (2018). Maldito otoño. Maleïda tardor. Riba-roja de Túria: Alupa editorial. 
La SubTerránea (2018). Como las cosas amables. Texto inédito.

La SubTerránea (2017). Martingala. Riba-roja de Túria: Alupa editorial.

La SubTerránea (2016). Urbach-Wiethe. Texto inédito.

La SubTerránea (2015). «O todo lo contrario», València: Red escénica, núm. 4.

La SubTerránea (2013). Pussy Koan. Texto inédito.

Liehmann, Hans-Thies (2006). «Ideologia i teatre postdramàtic». Barcelona: Pausa. núm. 25.

March Tortajada, R. (2020). Entrevista inédita.

March Tortajada, R. (2016). «Martingala», València: Episkenion.

Nancy, J. L. (2006). Ser singular plural. Madrid: Arena Libros.

Pardo, J. L. (2012). Políticas de la intimidad (Ensayo sobre la falta de excepciones). Madrid: Escolar y Mayo.

Topor, Roland. (2017). Acostarse con la reina. Barcelona, Buenos Aires, México: Libros del zorro rojo.

Valcárcel, A. (2014). Feminismo en un mundo global. Madrid: Cátedra. 